IARA REBOUÇAS PINHEIRO

ESTUDO DA PRODUÇÃO DO ANTIÓTICO ANTITUMORAL RETAMICINA EM BIORREATORES COM CÉLULAS IMOBILIZADAS DE STREPTOMYCES OLINDENSIS ICB20 
IARA REBOUÇAS PINHEIRO

\section{ESTUDO DA PRODUÇÃO DO ANTIBIÓTICO ANTITUMORAL RETAMICINA EM BIORREATORES COM CÉLULAS IMOBILIZADAS DE STREPTOMYCES OLINDENSIS ICB20}

Tese apresentada à Escola

Politécnica da Universidade de São Paulo para obtenção do título de

Doutora em Engenharia.

Área de Concentração:

Engenharia Química

Orientadora:

Prof $^{a} \operatorname{Dr}^{a}$ Maria Cândida Reginato Facciotti 


\section{FICHA CATALOGRÁFICA}

\section{Pinheiro, lara Rebouças}

Estudo da produção do antibiótico antitumoral retamicina em biorreatores com células imobilizadas de Streptomyces olindensis ICB20/ I.R. Pinheiro. -- São Paulo, 2007. $136 \mathrm{p}$.

Tese (Doutorado) - Escola Politécnica da Universidade de São Paulo. Departamento de Engenharia Química.

1.Streptomyces 2.Antibiótico 3.Reatores bioquímicos 4.Células imobilizadas I.Universidade de São Paulo. Escola Politécnica. Departamento de Engenharia Química Il.t. 
"Não sei o que possa parecer aos olhos do mundo, mas aos meus pareço apenas ter sido como um menino brincando à beira-mar, divertindo-me com o fato de encontrar de vez em quando um seixo mais liso ou uma concha mais bonita que o normal, enquanto o grande oceano da verdade permanece completamente por descobrir à minha frente." 
À minha filha Ingrid, razão da minha vida. 


\section{AGRADECIMENTOS}

À Professora Maria Cândida, pela sua orientação, apoio e amizade no decorrer deste trabalho.

À minha mãe Ivonete, pelo seu amor e apoio tão necessários nesta etapa da minha vida.

Ao Roberto, pelo seu amor, dedicação e companheirismo em todos os momentos que vivenciamos juntos, os quais foram muito importantes para realização deste trabalho.

Aos professores Aldo, Andréas, Beatriz e Pedro, os quais contribuíram direta e indiretamente para realização deste trabalho.

Aos colegas de trabalho: Sandra, Gisele, Daniela, Letícia, Patrícia, Roberta, Mariana, Jorge, Olavo, Fabiano, Gustavo, Harm e Saul pelos momentos de trabalho compartilhados ao longo destes quatro anos.

À amiga Luciana pela sua amizade tão especial, desde o mestrado, e que mesmo distante sempre me deu apoio para que eu chegasse ao final desta etapa da minha vida.

Aos alunos que durante a graduação contribuíram para a realização deste trabalho na forma de estágio e iniciação científica: Marcos, Octávio, Luís e Rafael.

Aos funcionários do Departamento: Orlinda, Andréa, Valter, Elisete, Graça, Alexandre, Maria Lúcia e Fátima, por contribuírem para a realização deste trabalho.

Ao Cnpq e à FAPESP pelo apoio financeiro necessário para a realização deste trabalho. 


\section{RESUMO}

O objetivo deste trabalho foi estudar a produção do antitumoral retamicina por células imobilizadas de Streptomyces olindensis ICB20 em biorreatores. A imobilização das células foi conseguida após uma etapa inicial de cultivo em erlenmeyers (reativação e pré-imobilização) e posterior envolvimento em gel, utilizando-se alginato de cálcio 3\%; as esferas produzidas tinham diâmetro médio de $3,0 \pm 0,2 \mathrm{~mm}$. Foram utilizados neste trabalho os biorreatores tipo cesta $(2,4 \mathrm{~L}$ de volume útil) e coluna de bolhas (1,6 L de volume útil), efetuando-se cultivos em batelada simples, bateladas repetidas e contínuos, visando-se uma comparação dos diferentes sistemas empregados. Também foram realizados alguns cultivos com células livres, a fim de efetuar uma comparação com os sistemas com células imobilizadas nos diferentes biorreatores. Os ensaios consistiram em empregar diferentes condições de agitação (300 e 500 rpm) e aeração (0,4 e 1 vvm) para o biorreator cesta em sistema com células imobilizadas, assim como diferentes vazões de aeração no biorreator coluna de bolhas (1, 2 e 3 vvm). Os cultivos em bateladas repetidas e contínuos foram operados a partir das melhores condições obtidas nos cultivos descontínuos. Foram aplicadas nos sistemas contínuos com células imobilizadas, as vazões específicas de alimentação de 0,05 e $0,2 \mathrm{~h}^{-1}$ no biorreator cesta e vazões de 0,015 a $0,05 \mathrm{~h}^{-1}$ no biorreator coluna de bolhas. A comparação entre os sistemas com células livres e imobilizadas mostrou que as limitações difusionais afetaram significativamente as cinéticas dos ensaios com células imobilizadas, considerando-se apenas uma batelada. A operação do biorreator cesta em sistema de bateladas repetidas apresentou os maiores valores de produção da retamicina (em torno de 1,5 a 1,7 UA), porém sua operação foi possível por apenas três bateladas. O sistema contínuo operado com vazão específica de alimentação de $0,03 \mathrm{~h}^{-1}$, com células imobilizadas no biorreator coluna de bolhas, mostrou ser o mais adequado dentre todos os ensaios realizados com células imobilizadas, apresentando estabilidade na produção, em torno de 0,8 UA, durante 96 horas de alimentação (cerca de três tempos de residência).

Palavras-chave: Streptomyces olindensis, retamicina, imobilização, biorreator cesta, biorreator coluna de bolhas 


\begin{abstract}
The purpose of this study was to investigate the production of the antitumor antibiotic retamycin by immobilized cells of Streptomyces. olindensis ICB20 in bioreactors. Cells were immobilized by entrapment in Ca-alginate gel (3\%) after being grown in Erlenmeyers (reactivation and pre-immobilization cultures). The average diameter of the Ca-alginate beads was $3.0 \pm 0.2 \mathrm{~mm}$. Aiming to compare different cell systems, immobilized cell cultures were carried out in a $2.4 \mathrm{~L}$ working volume basket-type stirred tank reactor (BSTR) and a $1.6 \mathrm{~L}$ working volume bubble column reactor (BCR) in batch, repeated-batch and continuous modes. Free cell suspension cultures were also performed and the results obtained compared to those in immobilized cell systems. Different agitation rates (300 and $500 \mathrm{rpm})$ and air flow rates (0.4 and 1.0 v.v.m.) were employed in the BSTR immobilized cell experiments. The BCR cultures were conducted at 1.0, 2.0 and 3.0 v.v.m. The optimal operating conditions for the batch mode were used in the repeated-batch and continuous cultures. Immobilized cells were grown in continuous mode at feed dilution rates of 0.05 and $0.2 \mathrm{~h}^{-1}$ in the BSTR and at 0.015 and $0.05 \mathrm{~h}^{-1}$ in the BCR. The comparative evaluation of the batch cultures with free and immobilized cells showed that diffusion limitations had affected the kinetics of cell growth and retamycin production in the immobilized cell systems. The highest average values of retamycin content (from 1.5 to $1.7 \mathrm{AU}$ ) were achieved in repeated batch cultures conducted in the basket-type reactor (BSTR) in spite of a limited number of batches ( 3 batches). Of all the systems, the continuous cell immobilized culture carried out in the BCR at a dilution rate of $0.03 \mathrm{~h}^{-1}$ proved to be the most adequate for retamycin production as retamycin levels remained stable (around $0.8 \mathrm{AU}$ ) over 96 hours (about 3 residence times).
\end{abstract}

Keywords: Streptomyces olindensis; retamycin, immobilization; basket-type tank reactor; bubble column reactor. 


\title{
SUMÁRIO
}

\author{
RESUMO \\ ABSTRACT \\ LISTA DE FIGURAS \\ LISTA DE TABELAS \\ LISTA DE SÍMBOLOS \\ SUMÁRIO
}

1. INTRODUÇÃO

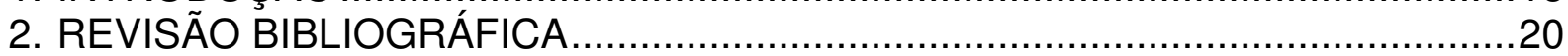

2.1. A bactéria Streptomyces olindensis $\quad 20$

2.2. Os Antitumorais e a Retamicina 21

2.3. Imobilização de células $\quad 24$

2.3.1. Método de envolvimento 26

2.3.1.1. Limitações de transferência de massa nos sistema de imobilização 28

2.4. Aplicações de células imobilizadas em bioprocessos 30

2.4.1. Produção de antibióticos por células imobilizadas 30

2.4.2. Outras aplicações de células imobilizadas em bioprocessos 36

2.4.2.1.Produção de Álcoois 36

2.4.2.2.Produção de bebidas $\quad 37$

2.4.2.3.Produção de metabólitos por células animais 38

2.5. Transferência de Oxigênio 39

2.6. Sistemas e reatores empregados. 43

2.6.1. Biorreator tipo cesta ("basked stirred tank reactor" - BSTR) 43

$\begin{array}{lll}\text { 2.6.2. Biorreator coluna de bolhas } & 45\end{array}$

2.6.3. Propriedades fluidodinâmica dos biorreatores coluna de bolhas $\quad 49$

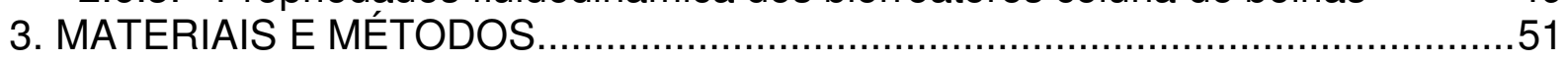

3.1. Microrganismo $\quad 51$

3.2. Meio de cultura 51

3.3. Preparo do Estoque e Conservação da Cepa 53

3.4. Condições dos ensaios realizados $\quad 53$

3.4.1. Reativação do micélio 53

3.4.2. Cultivo pré-imobilização $\quad 54$

3.4.3. Imobilização das células $\quad 54$

3.4.4. Cultivos em biorreator tipo cesta $\quad 55$

3.4.4.1. Descrição do biorreator tipo cesta 55

3.4.4.2. Cultivos em batelada simples no biorreator tipo cesta com células livres e imobilizadas.

3.4.4.3. Cultivos em bateladas repetidas no biorreator cesta com células imobilizadas 59

3.4.4.4. Cultivos contínuos no biorreator tipo cesta com células imobilizadas 59

3.4.5. Cultivos em biorreator coluna de bolhas 60

3.4.5.1. Descrição do biorreator coluna de bolhas 60

3.4.5.2 Cultivos descontínuos com células livres e imobilizadas em biorreator coluna de bolhas

3.4.5.3. Cultivos em bateladas repetidas com células imobilizadas em biorreator coluna de bolhas

3.4.5.4. Cultivos contínuos com células imobilizadas biorreator coluna de bolhas 
3.5. Determinações analíticas

3.5.1. Concentração celular livre 63

3.5.2. Concentração celular imobilizada 64

3.5.3. Concentração residual de glicose 66

3.5.4. Produção de retamicina no meio 67

3.6. Tratamento de resultados 67

3.6.1. Cálculo dos fatores de conversão, produtividades e produção específica, no cultivo com células livres e imobilizadas em batelada simples

3.6.2. Cálculo dos fatores de conversão, produtividades e produção específica, no cultivo com células imobilizadas em bateladas repetidas

3.6.3. Cálculo das Velocidades Específicas para os ensaios em bateladas simples

3.6.4. Cálculo das velocidades específicas, fatores de conversão e produtividades nos ensaios contínuos

4. RESULTADOS E DISCUSSÃO

4.1. Ensaios em biorreator tipo cesta ........................................................... 74

4.1.1 Ensaios em biorreator tipo cesta em bateladas simples sob diferentes condições de transferência de oxigênio

4.1.2. Ensaios em bateladas repetidas no biorreator tipo cesta com células imobilizadas.

4.1.3.Ensaios contínuos em biorreator tipo cesta

4.1.3.1. Ensaio contínuo com alta vazão específica de alimentação 89

4.1.3.2. Ensaios contínuos com baixa vazão específica de alimentação 90

4.2. Ensaios no biorreator coluna de bolhas

4.2.1. Ensaios com células imobilizadas no biorreator coluna de bolhas em batelada simples

4.2.2 - Ensaios no biorreator coluna de bolhas com células livres em bateladas simples.

4.2.3.Comparação entre os ensaios realizados no biorreator coluna de bolhas

4.2.4. Ensaios em bateladas repetidas no biorreator coluna de bolhas com células imobilizadas

4.2.5. Ensaio no biorreator coluna de bolhas com células imobilizadas em sistema contínuo.

4.3. Comparação entre os ensaios em biorreatores cesta e coluna de bolhas 116

4.3.1. Comparação entre os ensaios em batelada simples

4.3.2. Comparação dos sistemas com células imobilizadas em sistema contínuo

e de bateladas repetidas

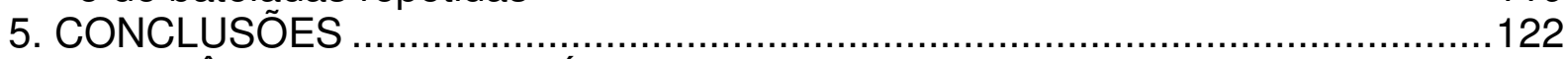

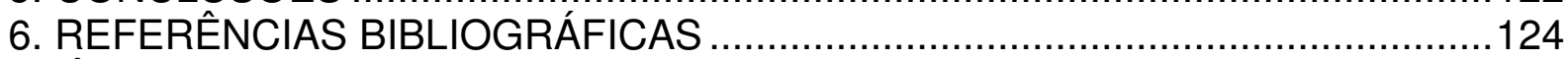

APÊNDICE A

APÊNDICE B

B.1. Ensaios para determinação do coeficiente volumétrico de transferência de oxigênio (Kla) e respiração nos biorreatores cesta e coluna de bolhas.

B.1.1. Determinação do Coeficiente volumétrico de transferência de oxigênio

B.1.2. Determinação da respiração através do método de balanço gasoso

B.1.3. Determinação do Kla em biorreatores cesta e coluna de bolhas sem cultivo

B.1.4. Determinação do Kla e respiração nos ensaios em biorreatores cesta e coluna de bolhas durante cultivo 


\section{INTRODUÇÃO}

A aplicação de bioprocessos fazendo uso de células imobilizadas em suportes tem sido objeto de estudo de diversas pesquisas em biotecnologia, por apresentarem uma série de vantagens, como permitir o uso repetido das células por um tempo prolongado, levar à obtenção de maiores valores de conversão de substrato a produto, possibilitar a utilização de projeto de biorreatores mais adequados à cinética do sistema biológico utilizado, entre outras (PRADELLA, 2001).

Dentre os métodos de imobilização utilizados nos diversos sistemas biológicos, o método por envolvimento em gel apresentou-se como um dos mais estudados na literatura, constituindo cerca de $76 \%$ dos trabalhos e destes, $43 \%$ utilizavam o alginato como matriz de imobilização, de acordo com o levantamento realizado por Gerbesh (1995).

A utilização de células imobilizadas em bioprocessos intensificou-se para a produção de metabólitos secundários, a partir de 1980 (WILLAERT, 1996). Em particular, na produção de antibióticos, a utilização de células imobilizadas tem um papel destacável, pois antibióticos são produtos derivados do metabolismo secundário das células, o qual se mostra ativo em casos de estresse e condições adversas do meio de cultura. Diversos estudos mostram que o confinamento celular acaba levando a taxas de produção mais elevadas em comparação ao cultivo com células livres, como é apresentado por Takashima (1987) para a produção de daunorrubicina, o qual obteve maiores valores de concentração de produto nos cultivos com células imobilizadas em comparação com os cultivos com células livres. Srinivasulu et al. (2002) também observaram que o cultivo de células de Streptomyces marinensis imobilizadas em alginato de cálcio, apresentou um valor superior de produção de neomicina em relação ao cultivo com as células livres.

$O$ estudo da produção do antitumoral retamicina pela linhagem Streptomyces olindensis ICB20 encontra-se em desenvolvimento no Laboratório de Engenharia Bioquímica do Departamento de Engenharia Química da Escola Politécnica da USP (LEB/DEQ/EPUSP) desde o final da década de 1990. Alguns trabalhos realizados anteriormente estudaram temas como: diferentes formas de condução do processo 
(PAMBOUKIAN, 2003), a influência das fontes de carbono e nitrogênio e de limitações nutricionais (GUIMARÃES, 2005; INOUE, 2006) e a comparação de diferentes suportes para a imobilização das células (AZEVEDO, 2005).

Em particular, o trabalho de Azevedo (2005) observou que entre os diferentes suportes testados para a imobilização de $S$. olindensis ICB20, o gel de alginato de cálcio mostrou-se nitidamente superior aos outros materiais, tendo em vista a manutenção da sua integridade por tempo prolongado, com manutenção de produtividade constante em retamicina, em cultivo realizado em incubador rotativo, no sistema de bateladas repetidas.

Como parte integrante desta linha de pesquisa, o presente trabalho teve como principal objetivo o estudo da produção da retamicina pela linhagem de Streptomyces olindensis ICB20 imobilizada em gel de alginato, a partir de cultivos em biorreatores do tipo cesta e coluna de bolhas. Convém ressaltar que este foi o primeiro trabalho do LEB/DEQ/EPUSP que estudou a produção de retamicina com células imobilizadas em biorreatores.

Dessa forma foram realizados, inicialmente, ensaios no biorreator tipo cesta em processo descontínuo com células livres e imobilizadas, com o objetivo de comparação do desempenho do processo em termos de crescimento celular, produção de retamicina, assim como para o estabelecimento da melhor condição de operação com células imobilizadas. Também foram realizados experimentos com células imobilizadas, em sistema de bateladas repetidas e em sistema contínuo (sob diferentes vazões específicas de alimentação), observando-se a capacidade de reutilização do gel de alginato e manutenção da produção da retamicina, para uma posterior comparação do desempenho dos diferentes sistemas.

Posteriormente foram realizados estudos no biorreator coluna de bolhas, os quais consistiram em cultivos em processo descontínuo sob diferentes vazões de aeração, tanto com células livres e com células imobilizadas, tendo-se em vista que não havia estudo anterior com $S$. olindensis ICB20 em biorreator coluna de bolhas. Para finalização do trabalho realizaram-se cultivos em sistema de bateladas repetidas e em sistema contínuo (sob diferentes vazões específicas de alimentação), com células imobilizadas, com a finalidade de encontrar a condição mais indicada para produção da retamicina com células imobilizadas. 


\section{REVISÃO BIBLIOGRÁFICA}

\subsection{A bactéria Streptomyces olindensis}

Streptomyces sp. são bactérias gram-positivas, filamentosas, aeróbias estritas, comumente encontradas no solo e ambientes aquáticos, sendo o principal gênero da família Streptomycetaceae, ordem dos Actinomicetales (LECHEVALIER; LECHEVALIER, 1981 apud PAMBOUKIAN, 2003). Os actinomicetos produzem centenas de compostos policetídeos, uma família de produtos naturais complexos e estruturalmente diversos, que incluem antibióticos (eritromicinas e tetraciclinas), agentes imunomoduladores, compostos parasiticidas (avermectina) e agentes antitumorais (antraciclinas) (NIELSEN, 1998 apud GUIMARÃES, 2005).

A linhagem selvagem Streptomyces olindensis DAUFPE 5622, isolada pelo Departamento de Antibióticos da Universidade Federal de Pernambuco, sintetiza a retamicina, que é um antibiótico caracterizado como antimicrobiano e antitumoral (LIMA et al., 1969). Dentre as características morfológicas deste microrganismo, destacam-se a esporulação e a pigmentação violeta do micélio, como conseqüência da síntese do antibiótico e excreção deste para o meio de cultivo.

Furlan (1997) realizou um tratamento mutagênico para esta linhagem selvagem S. olindensis, com o intuito de obter mutantes melhores produtores da retamicina. Neste tratamento foi utilizado o agente químico metil metano sulfonato (MMS), pois entre os agentes genotóxicos, os alquilantes são preferíveis à radiação ultravioleta por provocarem mutações pontuais, mais adequadas em programas de melhoramento genético de linhagens industriais. Dentre os mutantes obtidos por Furlan (1997), a linhagem S. olindensis ICB20 foi selecionada para estudos mais aprofundados. Esta linhagem mutante diferenciou-se morfologicamente em relação à linhagem selvagem pela perda da capacidade de esporulação. Os resultados de fermentação em incubador rotativo com as duas linhagens apresentaram um incremento na produção da retamicina e de biomassa, pela linhagem mutante $S$. olindensis ICB20. Provavelmente a mutagênese afetou as vias biossintéticas, bem como o processo de crescimento celular da linhagem selvagem, de forma que foi obtido um mutante melhor produtor do antibiótico (FURLAN, 1997). 


\subsection{Os Antitumorais e a Retamicina}

As antraciclinas estão entre os produtos naturais mais intensamente estudados nos últimos vinte e cinco anos, principalmente no que se relaciona aos mecanismos associados com sua atividade antineoplásica e toxicidade (STROHL et al., 1997), destacando-se a doxorrubicina, que é considerada o agente quimioterápico mais importante disponível e o mais utilizado em tratamentos contra o câncer (ALMEIDA et al., 2005). Como a maioria dos agentes antitumorais, as antraciclinas apresentam vários efeitos colaterais, sendo o mais grave a cardiotoxicidade cumulativa. Assim, as pesquisas nesta área concentram-se na busca de novas moléculas que apresentem menor toxicidade e/ou maior espectro de ação (GRÄFE et al. 1994; STROHL et al., 1997).

A estrutura geral das antraciclinas, apresentada por Flickinger (1999) é apresentada na Figura 2.1 a seguir:
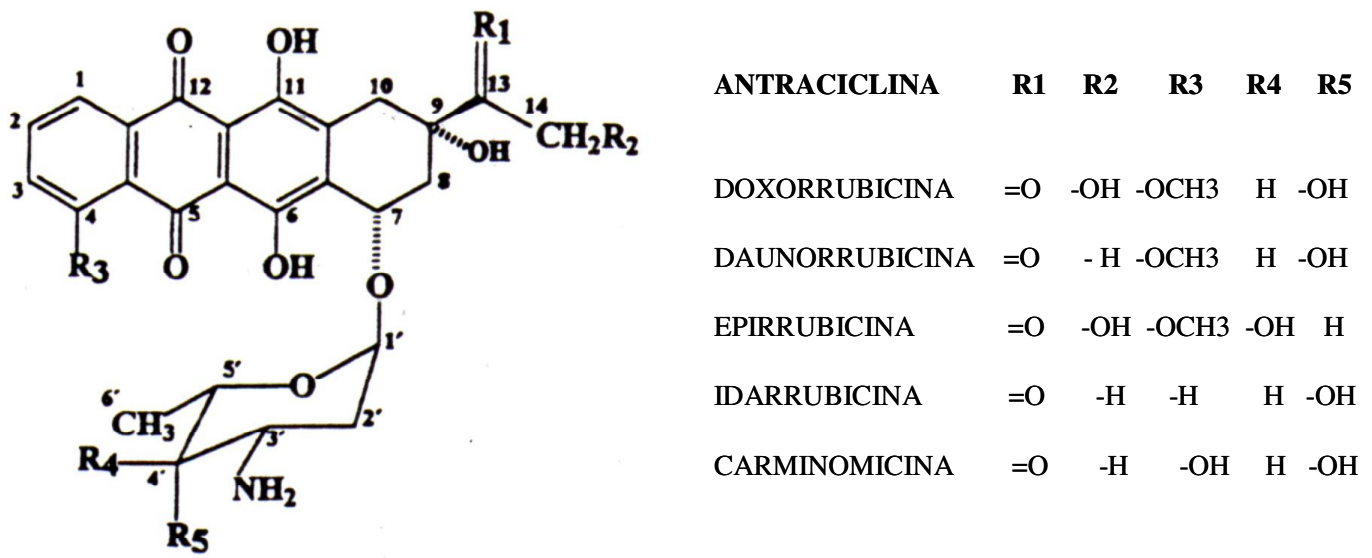

Figura 2.1 - Estrutura química de antraciclinas conhecidas (STROHL, 1997)

Pela Figura 2.1, podemos observar que as antraciclinas são formadas por um esqueleto aglicônico (7,8,9,10-tetraidro-5,12-naftaceno-quinona) e por uma fração glicosídica, na qual uma molécula ou uma cadeia de açúcares estão ligados à posição C-7 ou C-10, ou ainda em ambas posições da fração aglicônica (ECKARDT; 
WAGNER, 1988). Wang et al. (1995) estudaram as funções biológicas referentes às estruturas das antraciclinas, concluindo que a parte da aglicona é fundamental para a ligação da droga ao DNA e a parte glicosídica é essencial para que apresente atividade biológica.

O desenvolvimento de novos produtos antitumorais, bem como a melhoria dos produtos já existentes, caminham no sentido da manipulação genética (engenharia genética), elucidação dos mecanismos de ação das drogas, manipulação destes mecanismos e otimização dos processos naturais de obtenção (ARCAMONE, 1998). Por estes motivos, tem-se procurado isolar actinomicetos produtores de antraciclinas menos tóxicas, como foi o caso da retamicina, produzida pela linhagem selvagem Streptomyces olindensis DAUFPE 5622, descoberta durante pesquisas realizadas pelo Departamento de Antibióticos da Universidade Federal de Pernambuco na década de 1960 (LIMA et al., 1969).

Resultados referentes ao efeito apoptogênico (modo de ação apresentado pelas antraciclinas) do complexo retamicina foram apresentados por Furlan et al. (2002), apresentando níveis comparáveis aos da doxorrubicina. Recentemente foram identificados alguns dos constituintes do complexo (FURLAN et al., 2005; GARRIDO et al., 2006), sendo que duas das estruturas (FP2 e FP4) apresentaram similaridade com as moléculas da cosmomicina D e C, respectivamente (Figura 2.2).

A retamicina é um complexo antibiótico pertencente à classe das antraciclinas. Apresenta atividade antimicrobiana e antitumoral, e mostrou-se eficaz no tratamento quimioterápico de alguns tipos de câncer (LIMA et al., 1992), assimilando-se à doxorrubicina. Porém, estudos preliminares no tratamento da leucemia apresentaram vários efeitos colaterais como: arritmias (COTIAS et al., 1971), distúrbios cardiovasculares e gastrointestinais, esclerose vascular, cefaléia, entre outros (ASFORA et al., 1972). 

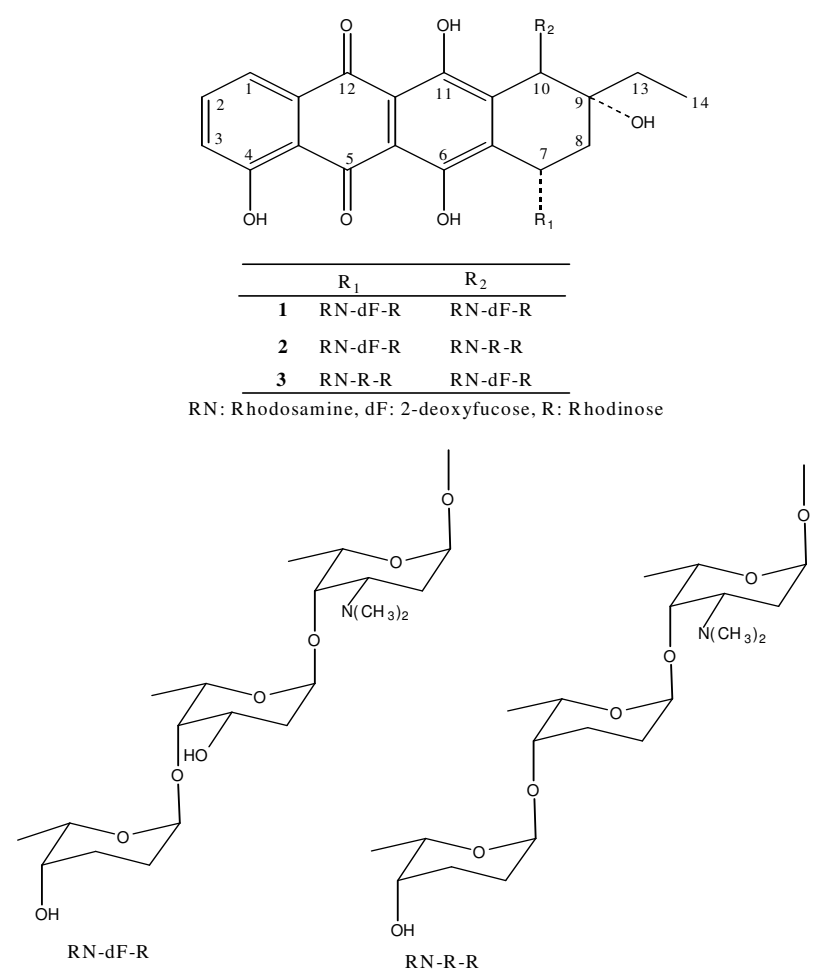

Figura 2.2 - Frações identificadas do complexo retamicina (FP2 = 1, FP4 = 2; FURLAN et al., 2005).

Estudos no sentido de melhorar o processo de produção da retamicina foram desenvolvidos no LEB/DEQ/USP, desde o final da década de 1990, abordando diferentes aspectos do processo, destacando-se entre eles:

Pamboukian et al. (2006) realizaram a comparação entre o processo descontínuo, descontínuo alimentado e contínuo, sendo que a maior produção de retamicina ocorreu em processo descontínuo alimentado, sendo de cerca de 1,76 UA (unidades de absorbância). No entanto, em termos de produtividade em retamicina, o processo contínuo com baixa vazão específica de alimentação ( $D$ = $0,05 \mathrm{~h}^{-1}$ ) apresentou um resultado superior aos demais tendo atingido o valor de 0,07 $\mathrm{UA} / \mathrm{h}$, valor este $79 \%$ superior à média dos ensaios descontínuos e $43 \%$ superior ao ensaio descontínuo alimentado.

Guimarães (2005) estudou a influência do meio de cultivo na produção da retamicina em cultivo descontínuo e descontínuo em duas etapas. No cultivo em duas etapas utilizou-se uma composição de meio que favorecesse o crescimento celular na primeira fase (Glicose $-10 \mathrm{~g} / \mathrm{L}$ e extrato de levedura $100 \mathrm{mM}$ ) e, na segunda, utilizou-se uma composição que favorecesse a produção da retamicina (Amido - $10 \mathrm{~g} / \mathrm{L} \mathrm{e} \mathrm{NaNO}_{3}-100 \mathrm{mM}$ ). Os resultados obtidos neste experimento foram 
os melhores obtidos para a produção e produtividade da retamicina, tendo em vista que foram obtidos cerca de 2,48 UA e 0,12 UA/h, respectivamente (considerando-se apenas a fase de produção).

Os primeiros resultados em processo com células $S$. olindensis imobilizadas em gel de alginato foram apresentados por Azevedo (2005), o qual estudou a imobilização de $S$. olindensis em diferentes suportes e otimizou as condições de imobilização no gel de alginato (esferas de $3 \mathrm{~mm}$, concentração de alginato de $3 \%$ e concentração celular inicial de $\left.2 \mathrm{~g} / \mathrm{L}_{\mathrm{gel}}\right)$.

\subsection{Imobilização de células}

A imobilização de células consiste no confinamento físico destas numa região definida do espaço, com preservação de suas atividades catalíticas (KAREL et al.,1985 apud WILLAERT, 1996). Esse confinamento é conseguido através do contato das células com algum material, chamado de suporte, sob condições ambientais controladas. Porém, também é possível se trabalhar com células imobilizadas naturalmente, denominadas pellets naturais (SARRÀ et al, 1997).

A escolha de um suporte para imobilização de células vivas depende de alguns critérios, como: não toxidez às células; alta capacidade de retenção; alta difusividade de substratos e produtos (PRADELLA, 2001).

Existem vários tipos de suportes, de diversos tipos de materiais, como por exemplo, materiais inorgânicos, polímeros naturais e polímeros sintéticos, conforme indicado na tabela 2.1. A sua utilização depende do método de imobilização e do microrganismo utilizado.

A classificação mais aceita para os métodos de imobilização divide as diferentes formas de imobilização em três tipos: adsorção, ligação covalente e envolvimento (PRADELLA, 2001). Porém alguns autores aceitam um outro tipo de classificação: adsorção em suportes sólidos; penetração em uma matriz porosa; auto-agregação por floculação (natural) ou com agentes de cross-link (induzida artificialmente); células contidas em barreiras (PILKINGTON et al., 1998). 
Tabela 2.1 - Materiais utilizados como suportes para a imobilização celular (PRADELLA, 2001).

\begin{tabular}{lll}
\hline Polímeros naturais & Polímeros sintéticos & Materiais inorgânicos \\
\hline Alginato & Poliacrilamida & Alumina \\
$\beta$-carragenana & Cloreto de polivinila & Sílica \\
Agar & Poliestireno & Zircônia \\
Pectina & Poliuretano & Vidro \\
Celulose & Polietileno glicol & Diatomita \\
Dextrana & & Vermiculita \\
Colágeno & & \\
\hline
\end{tabular}

Considera-se como adsorção a adesão de células em suportes que não foram especialmente funcionalizados para a ocorrência de ligação covalente. Os materiais mais utilizados por esse método são os inorgânicos e os polímeros sintéticos, mostrados na Tabela 2.1. No método da ligação covalente, os suportes são especialmente funcionalizados para conter um grupamento químico, o qual será responsável pela imobilização da célula ao suporte. Uma das técnicas mais utilizadas por esse método é a silanização de esferas de vidro, seguida de reação com glutaraldeído (PRADELLA, 2001).

Pelo método de adsorção, a espuma de poliuretano tem mostrado resultados interessantes na imobilização de Streptomyces, a qual foi empregada nos trabalhos de Ulgen; Mavituna (1994) Sridevi; Sridhar (1999) e Elibol (2002).

Azevedo (2005) realizou estudos para a imobilização de $S$ olindensis empregando os suportes diatomita, espuma de poliuretano e alginato de cálcio. $\mathrm{O}$ suporte que apresentou maior retenção das células (cerca de $88 \%$ ) foi o gel de alginato de cálcio. 


\subsubsection{Método de envolvimento}

Entre os diferentes métodos de imobilização de biocatalisadores discutidos em alguns trabalhos (SCOTT et al., 1987; LEO et al.; 1990, SERP et al., 2000), o método de envolvimento em gel é um dos mais utilizados para imobilização de células. O grande interesse nesse tipo de método de envolvimento é decorrente das suas vantagens, com destaque para o fato de o biocatalisador não se encontrar ligado quimicamente à matriz, permitindo assim, a imobilização de células microbianas de diferentes tamanhos sem diminuição da atividade biológica (KENNEDY; CABRAL, 1983).

Dentre os suportes aplicados no método por envolvimento, o alginato de cálcio tem apresentado posição de destaque, pois tem sido referenciado como melhor opção dentre outros suportes, como visto nos trabalhos de Veelken; Pape (1982), Beg, et al.(2000) e Sridevi; Sridhar (2000).

$O$ alginato é um polissacarídeo de composição baseada principalmente na existência de dois monômeros, o ácido manurônico $(M)$ e o ácido gulurônico $(G)$, como mostrado a seguir na Figura 2.3:

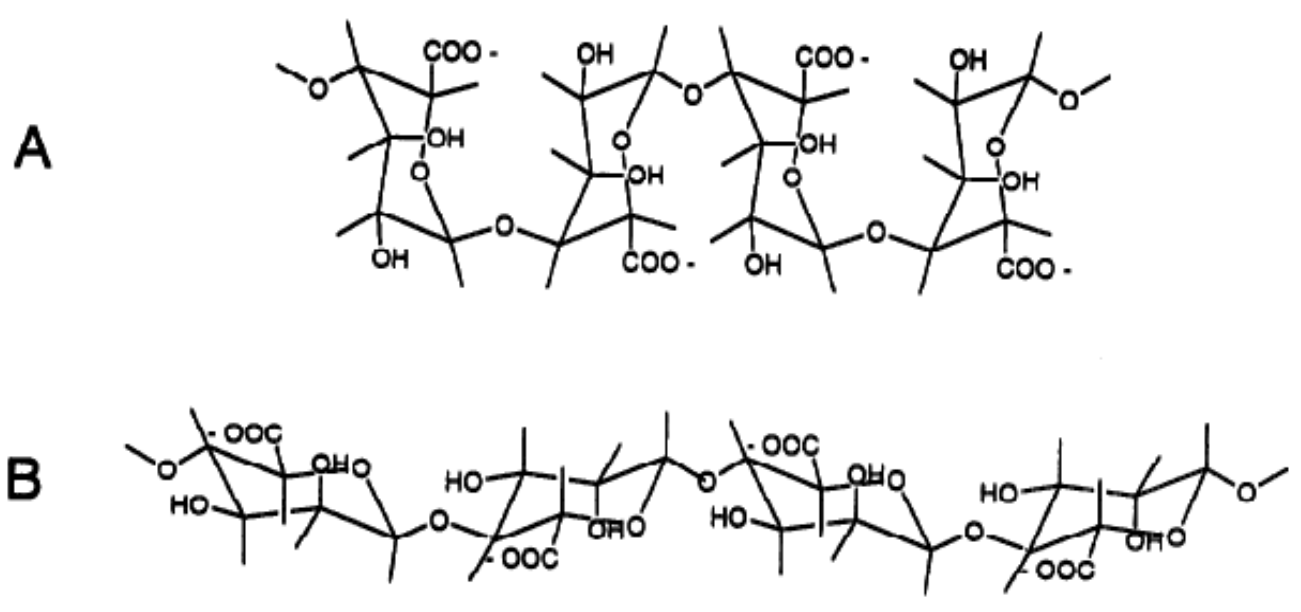

Figura 2.3 - Estruturas do alginato - (A) ácido gulurônico, (B) ácido manurônico (AMSDEN,B; TUNER, N. 1998). 
As propriedades de formação de um gel e a seletividade pela ligação de cátions irão depender da composição e da seqüência desses monômeros, enquanto que a viscosidade da solução polimérica depende quase exclusivamente do tamanho molecular do polímero e está relacionada basicamente com o comprimento da cadeia polimérica.

A formação do gel se dá pelo gotejamento da solução de alginato de sódio (solúvel em água) em uma solução contendo cloreto de cálcio. A ligação de íons $\mathrm{Ca}^{+2}$ se dá preferencialmente nos blocos $\mathrm{G}$. O íon cálcio é incorporado na molécula de alginato, provocando a formação de uma estrutura tridimensional denominada egg-box (GRANT et al., 1973, BUCKE, 1987), esta conformação permite a formação característica dos géis, sendo a gelificação quase instantânea na superfície do gel, dirigindo-se para o interior da esfera.

Após a imobilização, é necessário que as partículas de gel passem por um período de cura para melhorar as suas propriedades mecânicas, tornando-as mais resistentes para as aplicações desejadas.

Cheetam et al. (1979) estimaram que a quantidade necessária para gelificar uma certa quantidade de alginato era de $0,065 \mathrm{~g} \mathrm{Ca} / \mathrm{g}$ alginato. Em termos de concentração de alginato e de cloreto de cálcio para a formação de um gel estável foram obtidos os valores de $1 \%(\mathrm{p} / \mathrm{v})$ de alginato e $0,1 \mathrm{M}$ de cloreto de cálcio, sendo estes valores dependentes do tipo de alginato empregado.

A desagregação do gel é importante para se estimar a concentração celular no interior do mesmo, sendo que o método mais utilizado é a solubilização em citrato de sódio, que tem um efeito semelhante ao íon fosfato. O tempo necessário para esta dissolução é dependente do diâmetro da esfera do gel, da concentração de alginato e principalmente do tipo de alginato. Alginato com alto teor de blocos $\mathrm{G}$ podem levar até algumas horas para dissolver, enquanto que alginato de baixo teor de blocos G levam de 5 a 30 minutos (LEE et al., 1991).

Barbosa Jr. (2003), mostrou as principais condições de preparação de géis obtidas em vários trabalhos:

- as concentrações de gel mais utilizadas encontram-se entre 1 e $3 \%$;

- os processos de esterilização mais utilizados foram a autoclavagem e a filtração;

- a concentração de $\mathrm{CaCl}_{2}$ para a maioria dos trabalhos variou de 1 a $2 \%$; 
- o tempo de cura variou bastante dentre os vários trabalhos (desde 5 minutos até 24 horas);

- os tampões utilizados para dissolução do gel foram o citrato de sódio, fosfato de sódio, EDTA e hexametafosfato.

A estabilidade do gel durante o cultivo está relacionada diretamente com a porcentagem de blocos $G$ do alginato, sendo determinada principalmente pela composição química estrutural dos blocos e independente do peso molecular (BARBOSA Jr., 2003). Meios de cultivo que apresentem íons fosfato podem provocar a ressolubilização do gel (VORLOP; KLEIN, 1987).

\subsubsection{Limitações de transferência de massa nos sistema de imobilização}

No sistema de imobilização por envolvimento deve-se considerar que os aspectos de transporte de massa são um fator decisivo para o sucesso do processo. Quando as partículas de gel estão em contato com o meio de cultura, estabelece-se um fluxo de substrato para dentro das partículas. Este substrato é transportado por difusão até as células onde é convertido em produto. Da mesma forma, o produto é transportado por difusão até a parede do suporte, e daí para o meio de cultura, onde é acumulado.O tamanho da partícula, a difusividade das espécies através da matriz polimérica e a concentração celular na partícula devem ser otimizadas para minimizar esses problemas.

Neste sentido Azevedo (2005) estudou, através de um planejamento fatorial, a influência do diâmetro do gel de alginato de cálcio, da concentração celular no gel e da concentração de alginato na produção de retamicina com células de $S$. olindensis ICB20 imobilizadas em gel de alginato de cálcio, observando que as melhores condições foram gel de $3 \mathrm{~mm}$, concentração de alginato de $3 \%(\mathrm{p} / \mathrm{v})$ e concentração celular inicial de $2 \mathrm{~g} / \mathrm{L}_{\mathrm{gel}}$.

As principais desvantagens da imobilização de células utilizando-se a técnica de envolvimento são as limitações de transferência de massa impostas pela matriz de imobilização, observando-se o crescimento celular mais intenso nas regiões 
próximas da superfície da esfera, o que ocasiona também a liberação de células da matriz (LACCA et al., 2000).

A figura 2.4 ilustra o crescimento celular de $S$. marcescens mais intenso na região próxima à superfície do gel (raio $r / R=0,89$ ). Lacca et al. (2000) mostrou que a técnica de microscopia óptica permitiu a obtenção de resultados quantitativos a respeito da distribuição das células dentro da matriz de imobilização. Lacca et al. (2000) também relatam que, nas partículas de alginato, os efeitos de inchamento e encolhimento observados podem necessitar ser introduzidos num modelo de difusão, o que torna mais difícil a resolução dos modelos matemáticos.
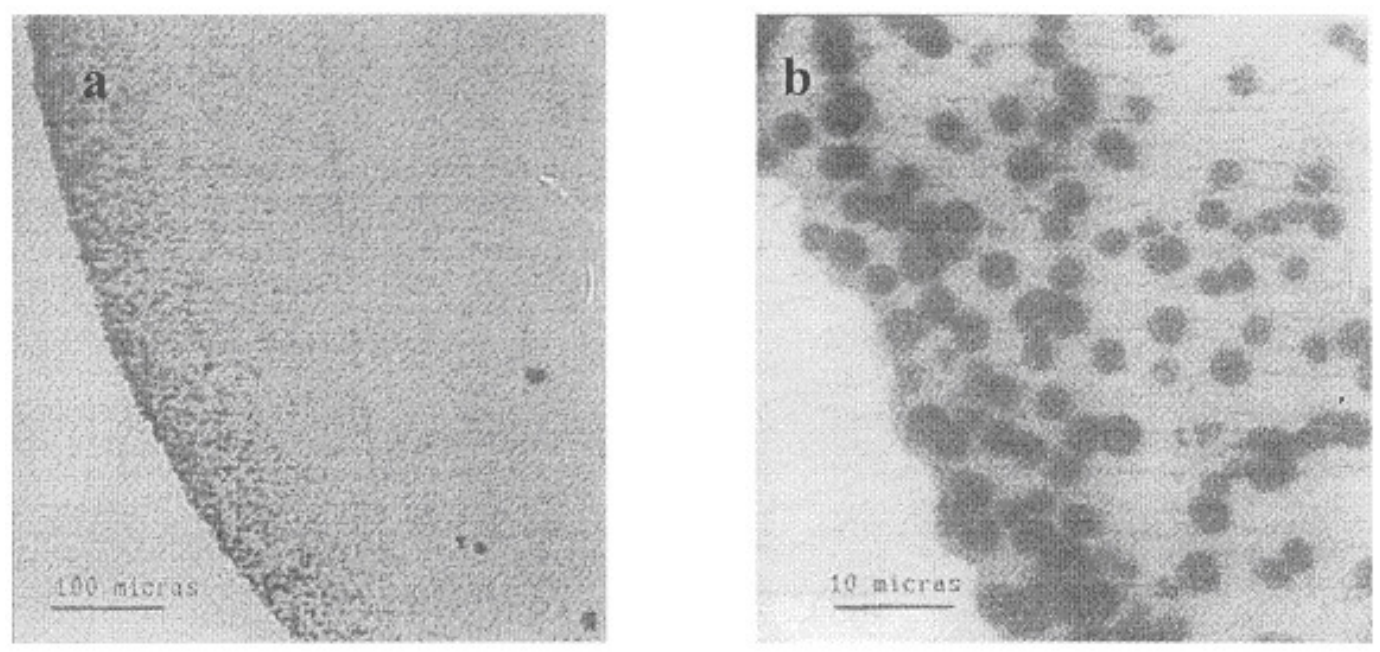

Figura 2.4 - Microscopia óptica de S. marcescens imobilizada em alginato, raio da seção $r / R=0,89$ (LACCA et al., 2000)

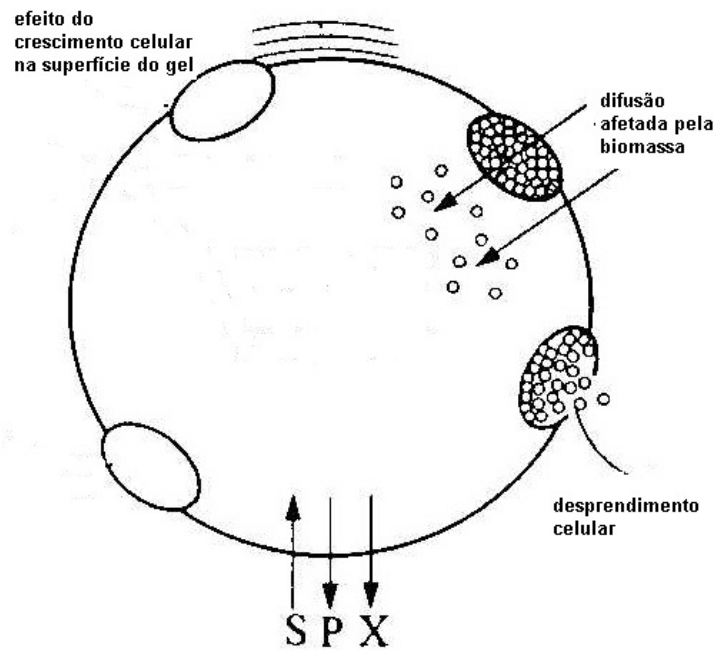

Figura 2.5 - Esquema de alguns aspectos considerados no modelo para o sistema com células imobilizadas (adaptado de LACCA et al., 2000). 
O modelo de limitação de transferência de massa sugerido por Wiffels (2001) levou em consideração que o passo limitante para a transferência de massa para o interior do gel é a difusão de substratos para o seu interior. Sugeriu um modelo em que as partículas eram esféricas, cinética de ordem zero e primeira ordem, cinética de Monod, concentração de biomassa imobilizada constante com o tempo e distribuída homogêneamente no suporte. Porém, quando a concentração de biomassa aumentou, o efeito da limitação de difusão se tornou importante resultando em um crescimento não homogêneo, assim como o modelo considerado por Lacca et al. (2000).

\subsection{Aplicações de células imobilizadas em bioprocessos}

A utilização de processos com células imobilizadas tem sido objeto de estudo em diversas áreas da biotecnologia, visando a produção de antibióticos, ácidos orgânicos, álcoois, entre outros.

Em particular, a utilização da imobilização tem sido reportada como uma alternativa interessante para os processos que utilizam microrganismos filamentosos, pois estes geram uma alta viscosidade no meio de cultivo e conseqüentemente ocasionam dificuldades na transferência de nutrientes e oxigênio (CRUZ et al., 2004).

A produção de etanol, bebidas alcoólicas, antibióticos e metabólitos a partir de células animais, e tratamento de efluentes são algumas das importantes aplicações em bioprocessos onde se pode empregar a técnica de imobilização celular.

\subsubsection{Produção de antibióticos por células imobilizadas}

Os processos convencionais de produção de antibióticos reportados na literatura normalmente são processos descontínuos. Na maioria dos casos a produção é não-associada ao crescimento e ocorre sob baixas velocidades 
específicas de crescimento celular, acarretando dificuldades em se operar sistemas contínuos com células livres por longos períodos (RAMAKRISHNA, 1999).

A produção de antibióticos pode ser favorecida por processos que utilizam células imobilizadas, apresentando de imediato duas vantagens em relação aos processos em batelada simples: a primeira seria a obtenção de alta concentração celular já no início do cultivo, resultando conseqüentemente em uma maior produtividade e, posteriormente, o fato de poder reutilizar as células tanto em um sistema de bateladas repetidas, como em sistema contínuo.

Grande parte dos processos para produção de antibióticos utilizam microrganismos filamentosos do gênero Streptomyces.

A Tabela 2.2, apresenta alguns exemplos de trabalhos que estudaram a produção de antibióticos com células imobilizadas de Streptomyces.

Tabela 2.2 - Antibióticos produzidos por células imobilizadas de Streptomyces

\begin{tabular}{ccc}
\hline Antibiótico & Suporte & Referência \\
\hline Actinomicina D & Alginato & Dalili; Chau (1988) \\
\hline Clorotetraciclina & $\begin{array}{c}\text { Alginato/ } \\
\text { carragenana }\end{array}$ & $\begin{array}{c}\text { Mamoud e Rehm (1986); } \\
\text { Gountier et al. (1997) }\end{array}$ \\
\hline Daunorrubicina & Alginato/PVA & Takashima et al. (1987) \\
\hline Cefamicina C & Alginato/espuma de & Sridevi; Sridhar (1999) \\
& poliuretano & Araújo et al. (1999); \\
Cefamicina C & Alginato/celite & Cruz et al. (2004) \\
\hline Eritromicina & alginato & Bandyopadyay et al. (1993) \\
\hline Neomicina & alginato & Srinivasulu et al (2003b) \\
\hline Retamicina & Alginato/ & Azevedo (2005) \\
& Celite/ & \\
\hline
\end{tabular}

A seguir, são apresentados de forma resumida, uma série de trabalhos que aplicaram a técnica da imobilização em processos que utilizam este grupo de microrganismos. 
Takashima et al.(1987) realizaram estudos para a produção de daunorrubicina por células de Streptomyces peucetius imobilizadas em alginato de cálcio. A produção máxima de daunorrubicina produzida pelas células imobilizadas (100 $\mu \mathrm{g} / \mathrm{mL}$ ) foi superior à produzida pelas células livres $(75 \mu \mathrm{g} / \mathrm{mL})$. Nos ensaios em bateladas repetidas a adição de polivinilalcool (PVA) ao alginato no processo de imobilização foi de fundamental importância para a melhoria da estabilidade mecânica do gel durante os sucessivos cultivos, já que nos cultivos onde as células foram imobilizadas apenas em alginato a produção foi máxima no primeiro ciclo (100 $\mu \mathrm{g} / \mathrm{mL})$, decaindo nos ciclos seguintes $(20 \mu \mathrm{g} / \mathrm{mL})$.

Mahmoud e Rehm. (1987) estudaram a produção de clorotetraciclina por células imobilizadas de Streptomyces aurofaciens ATCC $10762 \mathrm{em}$ alginato de cálcio, em fermentação semicontínua e continua. Primeiramente comparou-se a produção semicontínua em culturas agitadas entre células livres e imobilizadas no gel de alginato de cálcio. As células imobilizadas eram transferidas repetidamente a um novo meio de produção, sendo que após o terceiro ciclo fermentativo houve uma reativação das esferas de alginato por incubação do meio de inóculo por 24 horas. Com isso houve um crescimento de 5,5 vezes na produção durante 4 ciclos, sendo que a reativação das esferas de alginato provocou um aumento na produção do antibiótico em apenas 1 ciclo. Estudou-se também a produção em biorreator coluna de bolhas e foi observado que, aumentando a aeração de 0,5 para $2 \mathrm{~L} / \mathrm{min} / 200 \mathrm{~mL}$, observou-se um crescimento na produtividade das células imobilizadas no primeiro ciclo de fermentação, mas um posterior aumento na aeração ocasionou uma perda de produtividade. No entanto, através da determinação do peso de micélio seco, constatou-se que um crescimento na aeração ocasionou um aumento na quantidade de biomassa, mas sem efeito na produção de clorotetraciclina. Já na fermentação continua, com células imobilizadas, a máxima produção foi alcançada a uma vazão específica de alimentação de $0,027 \mathrm{~h}^{-1}$ (com uma vazão de meio de cultura de $200 \mathrm{~mL} / 24 \mathrm{~h}$ e aeração de $2 \mathrm{~L} / \mathrm{min}$ ), sendo que um posterior aumento provocou queda na produção. Além disso, a fermentação foi caracterizada pela queda na produção ao longo do tempo de cultivo, devido, provavelmente, ao aumento do $\mathrm{pH}$ para 7,3. Comparando esta produção com a semicontínua, não houve melhora no sistema.

Bandyopadhyay et al. (1993) mostraram alguns resultados para produção de eritromicina por micélio de Streptomyces erytheus imobilizado em alginato de cálcio. 
Neste estudo foram realizados ensaios em bateladas repetidas em incubador rotativo por 15 ciclos. A produtividade foi máxima ( $58 \mu \mathrm{g} / \mathrm{mg}$ proteína celular) do terceiro ao nono ciclo onde foi empregada uma concentração de $1 \%$ de sacarose com $0,2 \%$ de L-leucina. Comparando o desempenho das células de $S$. erytheus livres e imobilizadas, verificou-se que a produtividade específica de eritromicina foi superior para as células imobilizadas $(1,10 \mu \mathrm{g} / \mathrm{mg} . \mathrm{h})$ em relação ao processo convencional com células livres $(0,7 \mu \mathrm{g} / \mathrm{mg} . \mathrm{h})$.

Teruel et al.(1997) estudaram a produção de clorotetraciclina e tetraciclina por células de Streptomyces aureofaciens imobilizadas em $\kappa$-carragenana, utilizando planejamento fatorial. Os parâmetros avaliados foram o percentual de $\kappa$-carragenana (1 a $2 \%$ e a concentração do cátion $\mathrm{K}^{+}(0,1$ a $1,1 \mathrm{M})$. Os resultados mostraram que a produção dos antibióticos em função do tempo de cultivo foi influenciada pela interação entre o percentual de $\kappa$-carragenana e a concentração do íon. As condições ideais obtidas a partir do planejamento fatorial foram: $2 \%$ de $\kappa$ carragenana e $1,1 \mathrm{M}$ de $\mathrm{K}^{+}$para produção da clorotetraciclina e $2 \%$ de $\mathrm{k}$ -

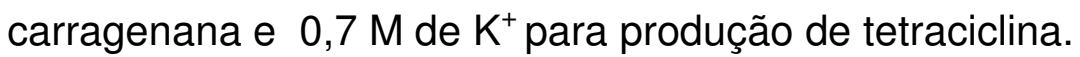

Devi e Sridhar. (2000) estudaram a produção de cefamicina C por células de Streptomyces clavuligerus imobilizadas em alginato de cálcio (concentração de alginato $4 \%$; diâmetro das esferas $0,28 \mathrm{~mm}$ ) e espuma de poliuretano durantes cultivos em bateladas repetidas. Neste trabalho os resultados de produção de cefamicina pelas células imobilizadas em espuma $(240 \mu \mathrm{g} / \mathrm{mL})$ foram superiores aos obtidos com as células imobilizadas em alginato $(160 \mu \mathrm{g} / \mathrm{mL})$, ambos os resultados considerados após 48 horas de cultivo da quinta batelada repetida.

Experimentos realizados por Srinivasulu et al. (2002) revelaram que a produção de neomicina utilizando Streptomyces marinensis imobilizado em alginato de cálcio foi $25 \%$ superior à obtida com células livres sob as mesmas condições, com pico máximo de produção de 72 horas e 96 horas, respectivamente. Além disso, a fase de adaptação durou cerca de 24 horas para o cultivo livre, enquanto que para o imobilizado, essa transição foi imperceptível. Tal fato sugere que o estresse induzido pela imobilização fez com que a produção do metabólito secundário fosse iniciada mais rapidamente.

Os efeitos dos parâmetros da imobilização foram avaliados por Srinivasulu et al. (2003b) para a produção de neomicina por S. marinensis imobilizado em alginato 
de cálcio. As variáveis estudadas foram: a concentração de alginato (1 a 5\% - p/v), o efeito do tipo de cátion $\left(\mathrm{CaCl}_{2}, \mathrm{BaCl}_{2}\right.$ e $\left.\mathrm{SrCl}_{2}\right)$, a concentração do cátion $(0,01$ a 0,5M), o tempo de cura (1 a 21 horas) e o diâmetro das esferas (1,48 a 5,44 mm). A melhor produção de neomicina foi obtida para uma concentração de alginato de $2 \%$, $025 \mathrm{M}$ de $\mathrm{CaCl}_{2}, 1$ hora de tempo de cura e diâmetro das esferas de 3,24 mm. Foram realizados ensaios em bateladas repetidas nestas condições otimizadas e foi observado um incremento da produção de neomicina até o quinto ciclo, a partir do qual a produção decresceu. Comparando a produtividade volumétrica específica de neomicina entre as células livres e imobilizadas foi observado que o cultivo com as células imobilizadas apresentou um valor superior $(67,1 \mathrm{mg} / \mathrm{mL}$.h) ao cultivo com as células livres $(50,9 \mathrm{mg} / \mathrm{mL} . h)$, concluindo-se então, que a imobilização de $S$. marinensis NUV-5 em alginato de cálcio foi mais eficiente para produção de neomicina com bateladas repetidas.

Uma outra vantagem de utilização de células imobilizadas na produção de antibióticos seria o emprego de processo contínuo, uma vez que, pelo fato das células estarem imobilizadas, o acesso aos nutrientes é dificultado e, conseqüentemente, o cultivo é mantido sob baixas velocidades específicas de crescimento, facilitando então o controle do processo e sendo possível também a utilização das células por um período mais prolongado do que o que se realizaria com células livres.

Alguns trabalhos em cultivos contínuos têm sido realizados em biorreatores do tipo airlift. Um exemplo é o trabalho de Adinarayana et al. (2004) que realizaram cultivos com Streptomyces marinensis NUV-5 em biorreator airlift para a produção de neomicina. A produtividade volumétrica máxima de neomicina $(112,5 \mathrm{mg} / \mathrm{L} . \mathrm{h})$ foi obtida para a vazão específica de alimentação (D) de $0,04 \mathrm{~h}^{-1}$ e 0 maior valor de produção de neomicina $(4000 \mathrm{mg} / \mathrm{mL})$ para $\mathrm{D}$ igual a $0,02 \mathrm{~h}^{-1}$. Este cultivo contínuo mostrou-se ser viável por um período de até 42 dias, indicando que a fermentação contínua com células imobilizadas é um processo mais econômico do que os processos em batelada.

Park e Khang (1995) investigaram a influência de diversos suportes na produção de cefalosporina $\mathrm{C}$ por Cephalosporium acremonium. $\mathrm{O}$ melhor resultado obtido foi a utilização do suporte alginato de bário com polietileno modificado, tendose observado a estabilidade do gel sem limitar a difusão. Um sistema contínuo com esta configuração operou satisfatoriamente por um período superior a 30 dias. 
Araujo et al. (1999) desenvolveram um estudo comparativo entre células de Cephalosporium acremonium livres e imobilizadas em gel de alginato de cálcio, para a produção de cefalosporina em biorreator convencional e biorreator tipo torre. Os autores observaram que as células livres apresentam melhores produtividades com base de cálculo na biomassa celular $(0,55$ contra $0,44 \mathrm{mgCPC} / \mathrm{gcel} / \mathrm{h})$, enquanto que as células imobilizadas apresentam produtividades maiores com base de cálculo na massa de sacarose consumida $(0,33$ contra $0,24 \mathrm{mgCPC} / \mathrm{gcel} / \mathrm{h})$, o que pode ser explicado pelo fato do consumo de sacarose pelas células imobilizadas ser bem mais lento. Por outro lado, o estudo da produção de cefalosporina por Cruz et al. (2004) demonstrou que a alimentação do meio com glicose em concentrações mais elevadas pode causar um efeito de repressão catabólica na produção deste antibiótico por Cephalosporium acremonium imobilizados em alginato de sódio, em leito fluidizado, diminuindo drasticamente as taxas de produtividade. Ou seja, a técnica de imobilização celular, não garante, por si só, que a produção de metabólitos secundários será maior, já que a composição do meio de cultivo também pode ser fator determinante.

Azevedo (2005) ao estudar a produção da retamicina em cultivos com células de S. olindensis ICB20 imobilizadas em gel de alginato, observou que a produção apresentou-se relativamente constante ao longo das bateladas repetidas em incubador rotativo, com uma média em torno de 0,62 UA. Este ciclo de 10 bateladas também favoreceu a produtividade, que se manteve em 0,017UA/h. Desse modo, constatou-se que este método se apresenta como uma boa alternativa para processos de longa duração. 


\subsubsection{Outras aplicações de células imobilizadas em bioprocessos}

\subsubsection{Produção de Álcoois}

A aplicação de processos com imobilização de células em sistemas de fermentação alcoólica tem sido objeto de estudo em diversos trabalhos, principalmente, desde a década de 1980 (WILLAERT; BARON, 1996), no sentido de aumentar a produtividade de etanol. A maior parte dos trabalhos publicados na literatura diz respeito à imobilização da biomassa em matrizes de gel ou resina, ou ainda através de ligações covalentes em diferentes superfícies.

Alguns trabalhos utilizando esta técnica apresentam resultados já em larga escala, como foi reportado por Nojima et al.(1983) apud Ramakrishna (1999), sendo os primeiros resultados de fermentação contínua em sistema utilizando células de leveduras imobilizadas. Uma planta piloto de 4.000 litros de capacidade foi operada utilizando células de levedura imobilizadas em alginato de cálcio para fermentação alcoólica, por um período de $4000 \mathrm{~h}$ com produção constante de álcool a uma concentração de 8,5 a $9 \%$ por volume.

Outros álcoois também são produzidos por processos utilizando células imobilizadas como pode se observado pela tabela a seguir.

Tabela 2.3 - Álcoois produzidos por células imobilizadas (RAMAKRISHNA, 1999)

\begin{tabular}{cccc}
\hline Álcool & Organismo & Suporte & Referência \\
\hline Etanol & levedura & Polímero & Lida et al. (1993) \\
Etanol & levedura & Alginato & Kazuaki et al (1994) \\
Etanol & Zymomonas mobilis & Matriz fibrosa & Castellar et al. (1994) \\
Etanol & levedura & Alginato & Gelson et al. (1993) \\
Etanol & Kluyveromyces & Alginato & Nolan et al (1994) \\
& marxianus & & \\
Butanol & Clostridium sp. & Alginato & Groot et al. (1987) \\
Glicerol & S. cerevisiae & Vidro sinterizado & Benito et al (1994) \\
Sorbitol & Z. mobilis & k-carragenana & Jang et al. (1992) \\
\hline
\end{tabular}


Tavares (1998) avaliou o desempenho da levedura Saccharomyces cerevisiae L36, imobilizadas em gel de pectina, no processo de fermentação alcoólica de amiláceos. Os resultados obtidos mostraram que foram atingidas altas concentrações celulares em biorreator tipo cesta ( $26 \mathrm{~g} / \mathrm{L}$ de reator), e que a atividade enzimática no interior das esferas manteve-se constante, ao longo do tempo, nos vários cultivos estudados (batelada, bateladas repetidas e contínuo).

A produção de xilitol em hidrolisado celulósico de bagaço de cana-de-açúcar por células imobilizadas de Candida guilliermondii vem sendo desenvolvida em diferentes sistemas (CARVALHO et al., 2002; SILVA et al., 2002; CARVALHO et al., 2003; CUNHA et al., 2006a,b; BRANCO et al., 2006; SARROUH et al. 2007) com o objetivo de aumentar a produtividade e encontrar um sistema mais adequado para sua aplicação em escala industrial.

\subsubsection{Produção de bebidas}

Um grande aumento do interesse na utilização de células imobilizadas para produção de bebidas alcoólicas tem sido notado recentemente. Usos industriais com células imobilizadas ainda são limitados, visto que sua aplicação irá depender do desenvolvimento de processos de imobilização reprodutíveis em grande escala (KOURKOUTAS et al., 2004).

Os principais usos encontrados na literatura do emprego de células imobilizadas na produção de bebidas alcoólicas são a produção de vinho e de cerveja.

Muitos suportes têm sido estudados para imobilização de leveduras na produção de vinho, destacando-se os polissacarídeos orgânicos e os alguns materiais inorgânicos abundantes na natureza. Entre os polissacarídeos orgânicos estudados, destacam-se os géis de alginato (SUZZI et al., 1996). Já entre os materiais inorgânicos destaca-se o mineral kissiris, um mineral vulcânico poroso de baixo custo encontrado na Grécia (ARGIRIOU et al., 1996).

Bakoyianis et al. (1992) estudaram a aplicação do mineral kissiris como suporte para a produção contínua de vinho. $O$ suporte se mostrou adequado para 0 cultivo sob baixas temperaturas $\left(5-16^{\circ} \mathrm{C}\right)$. A produtividade em temperatura de $5^{\circ} \mathrm{C}$ na 
fermentação contínua foi similar à observada na faixa de $22-25^{\circ} \mathrm{C}$ e a acidez do vinho produzido foi menor.

Ferraro et al. (2000) usaram células imobilizadas de Candida stellata em alginato de cálcio com um inóculo de Saccharomyces cerevisiae em uma planta piloto em condições não-estéreis. $O$ uso combinado dessas duas leveduras no processo de fermentação em grande escala produziu um vinho com características interessantes; a microflora selvagem no meio não-estéril não foi completamente controlada, porém notou-se um aumento na taxa de fermentação.

$O$ uso de alginatos e outros hidrogéis polissacarídeos, em geral, não oferecem uma boa alternativa para o uso industrial, devido ao seu alto custo, à baixa estabilidade mecânica e química, que resulta na liberação de células e resíduos no vinho. Muitos esforços têm sido feitos para a aplicação de géis de alginato na fermentação secundária do vinho já engarrafado, com o objetivo de melhorar a tecnologia do vinho com gás (BUSOVA et al., 1994; KOURKOUTAS et al., 2004).

Devido ao aumento da demanda de cerveja sem álcool durante as últimas décadas, muitos métodos de produção têm sido desenvolvidos, incluindo a remoção do álcool do produto acabado e a limitação da fermentação. No caso de fermentação limitada, o uso de células imobilizadas se mostra muito mais eficiente do que o uso de células livres (PILKINGTON et al., 1998).

\subsubsection{Produção de metabólitos por células animais}

Os processos biotecnológicos envolvendo células animais são diferentes de qualquer outro, pois estas células possuem características próprias. Em geral, seu crescimento é mais lento, são mais frágeis, possuem necessidades nutricionais e de aeração mais complexas e, em muitos casos, necessitam de um suporte (superfície) para que ocorra a adesão e o crescimento. Em geral, os metabólitos produzidos por células animais são proteínas que possuem alto valor agregado, como, por exemplo, substâncias imunológicas, bioinseticidas, enzimas e hormônios, sendo bastante complexo extraí-los do meio, principalmente devido à sua baixa concentração (AUGUSTO; OLIVEIRA, 2001). 
Uma grande variedade de vírus pode ser produzida utilizando células animais imobilizadas em microcarregadores para a produção de vacinas, por exemplo, vacinas contra rubéola, poliomielite raiva e gripe. A utilização deste método na produção de vacinas tem como vantagens a o aumento de produtividade, a diminuição de custos e a redução de contaminação quando comparado aos métodos tradicionais de cultivo (HEMERT et al., 1969; WEZEL et al., 1978).

Barbosa Jr. (2003) investigou a produção de anticorpos monoclonais a partir de hibridomas utilizando técnicas de imobilização celular (envolvimento e microencapsulação), em biorreatores, em processos semicontínuo e contínuo, obtendo concentrações celulares da ordem de $10^{7} \mathrm{cel} / \mathrm{mL}$ e produtividades três vezes superior aos métodos convencionais de cultivos de células livres, tendo este trabalho apresentado viabilidade técnica e econômica.

\subsection{Transferência de Oxigênio}

Em bioprocessos aeróbios, a capacidade de transferência de oxigênio para a fase líquida pode ser um fator limitante no processo, já que a existência de oxigênio dissolvido é imprescindível ao metabolismo celular para que haja oxidação completa da glicose e, no entanto, ao contrário de outros nutrientes presentes em tais processos, o oxigênio é muito pouco solúvel em água ( $\left.7 \mathrm{mg} / \mathrm{L} ; 30^{\circ} \mathrm{C} ; 1 \mathrm{~atm}\right)$. De nada adiantaria dissolver uma elevada concentração de nutrientes sem introduzir ao processo o oxigênio necessário para suportar a condição de aerobiose, tendo em vista a baixíssima capacidade de armazenar $\mathrm{O}_{2}$ na solução (SCHMIDELL, 2001).

Além da baixa solubilidade do oxigênio, a sua transferência da fase gasosa para a fase líquida em cultivos de bactéria e fungos filamentosos enfrenta a resistência física devido ao aumento da viscosidade do caldo durante os cultivos (CRUZ et al., 2004).

A concentração de oxigênio dissolvido é considerada muito importante em fermentações que visam a produção de antibióticos. A limitação por oxigênio pode estimular ou inibir a produção de metabólitos secundários, dependendo do microrganismo e das condições de agitação e aeração empregadas (MARTINS, 2001). 
As teorias que equacionam a determinação da transferência de oxigênio em sistemas fermentativos são bem difundidas, e dentre elas será abordada apenas a que permite o equacionamento da transferência de oxigênio considerando a existência de duas películas estagnadas na interface gás líquido (WHITMAN, 1923 apud SCHMIDELL, 2001).

A equação que descreve o fluxo de oxigênio por unidade de área interfacial é dada por:

$$
n_{O 2}=K_{g} H\left(p_{g}-p_{i}\right)=K_{L} H\left(p_{i}-p_{l}\right)=K_{g}\left(C_{s}-C_{i}\right)=K_{L}\left(C_{i}-C\right)
$$

onde:

$\mathrm{K}_{\mathrm{g}}=$ coeficiente de transferência de massa da película gasosa $(\mathrm{m} / \mathrm{h})$

$\mathrm{K}_{\mathrm{L}}=$ coeficiente de transferência de massa da película líquida $(\mathrm{m} / \mathrm{h})$

$\mathrm{P}_{\mathrm{g}}=$ pressão parcial de $\mathrm{O}_{2}$ no seio gasoso (atm)

$\mathrm{P}_{\mathrm{i}}=$ pressão parcial de $\mathrm{O}_{2}$ na interface (atm)

$\mathrm{P}_{\mathrm{I}}=$ pressão parcial de $\mathrm{O}_{2}$ em um gás que estaria em equilíbrio com a concentração de oxigênio $C$ no líquido, segundo a lei de Henry (atm)

$\mathrm{H}=$ constante de Henry $\left(\mathrm{gO}_{2} / \mathrm{m}^{3}\right.$.atm)

$C_{s}=$ concentração de oxigênio $C$ no líquido em equilíbrio com $p_{g}$, segundo a lei de Henry $\left(\mathrm{gO}_{2} / \mathrm{m}^{3}\right)$

$\mathrm{C}_{\mathrm{i}}=$ concentração de $\mathrm{O}_{2}$ dissolvido em equilíbrio com $\mathrm{p}_{\mathrm{i}}\left(\mathrm{gO}_{2} / \mathrm{m}^{3}\right)$

$\mathrm{C}=$ Concentração de oxigênio no seio do líquido $\left(\mathrm{gO}_{2} / \mathrm{m}^{3}\right)$

Para o caso de estar ocorrendo uma variação da concentração de $\mathrm{O}_{2}$ dissolvido (C) no tempo, pode-se escrever que,

$n_{O 2} \cdot a=\frac{d C}{d t}\left(\mathrm{gO}_{2} / \mathrm{m}^{3} \cdot \mathrm{h}\right)$,

assim:

$\frac{d C}{d t}=K_{L} a\left(C_{s}-C\right)$

onde

$\mathrm{a}=$ área interfacial de transferência de massa $\left(\mathrm{m}^{2}\right) /$ volume total de líquido $\left(\mathrm{m}^{3}\right)$ 
A partir da equação 2.3, aplicando o método de balanço gasoso (SCHMIDELL, 2001) é possível calcular o coeficiente volumétrico de transferência de oxigênio para sistemas que não contém células. Em cultivos microbianos é possível relacionar esta equação com a respiração celular de forma que teremos:

$\frac{d C}{d t}=K_{L} a\left(C_{s}-C\right)-Q_{O 2} X$

Em particular, nos cultivos com células imobilizadas cria-se um ambiente onde o transporte de oxigênio (Figura 2.6) até as células é mais difícil do que em cultivos de células livres, onde geralmente há limitação apenas pela interface gáslíquido e as células imobilizadas no interior do suportes tendem a formar agregados densos.

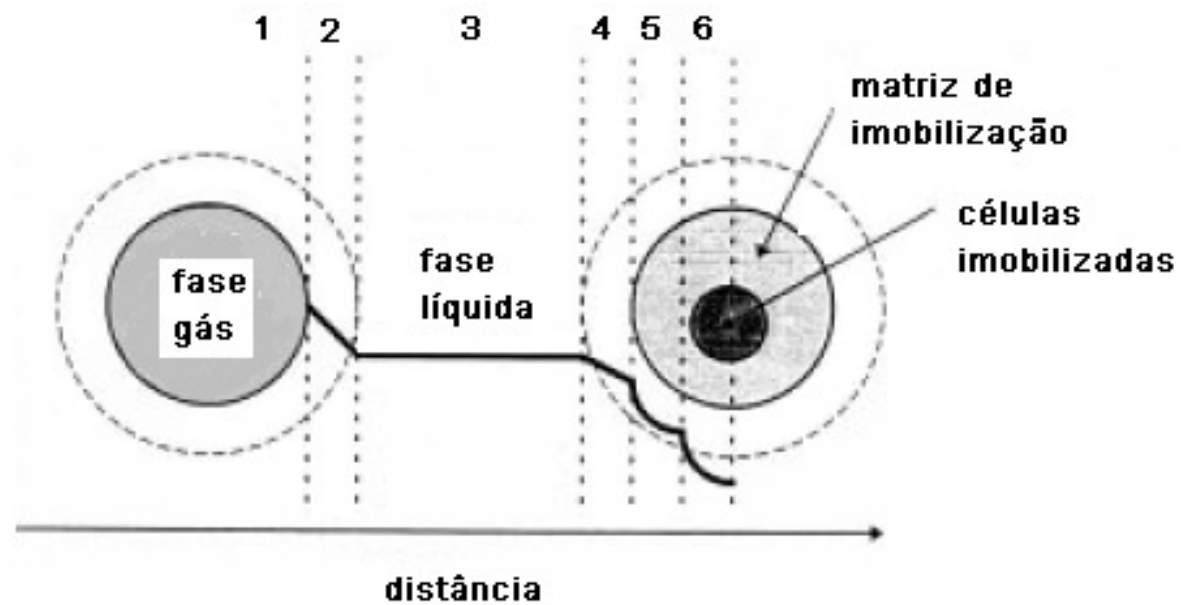

Figura 2.6 - Transporte de oxigênio da fase gasosa para a matriz com as células imobilizadas; 1-Fase gasosa; 2-filme líquido; 3-fase líquida; 4-filme líquido; 5-matriz de imobilização; 6-colônia de células imobilizadas (Adaptado, PILKINGTON et al., 1998).

Um outro aspecto que difere a transferência de oxigênio em cultivos de células imobilizadas em relação aos cultivos com células livres é que as células imobilizadas são densamente empacotadas, exigindo mais oxigênio por unidade de volume e o fornecimento de oxigênio deve compensar as resistências adicionais ao transporte de massa, como difusão intraparticular (CHANG, 1988). Nesta direção, 
alguns autores estudaram a variação da concentração de oxigênio dissolvido ao longo do raio das partículas.

Khang et al.(1988) apresentaram resultados obtidos para diversos perfis de fração de concentração de $\mathrm{O}_{2}$ em relação à concentração de $\mathrm{O}_{2}$ na superfície da partícula (Figura 2.7), para certa distância radial $r$ em relação ao centro da partícula. O sistema estudado era composto por Cephalosporium acremonium imobilizado em alginato de cálcio (2\%).

Ogbonna et al. (1991) apresentaram o conceito de diâmetro crítico de partículas para otimização de processos aeróbios. Para o processo estudado em seu trabalho, chegou ao diâmetro crítico de 0,3mm.

Entretanto, há um limite mínimo para operações práticas. O diâmetro mínimo da partícula depende do tamanho das células a serem imobilizadas e do sistema de reatores. Esse diâmetro também deve ser tal que imobilize um número razoável de células e que seja possível a operação contínua sem lavagem destas.

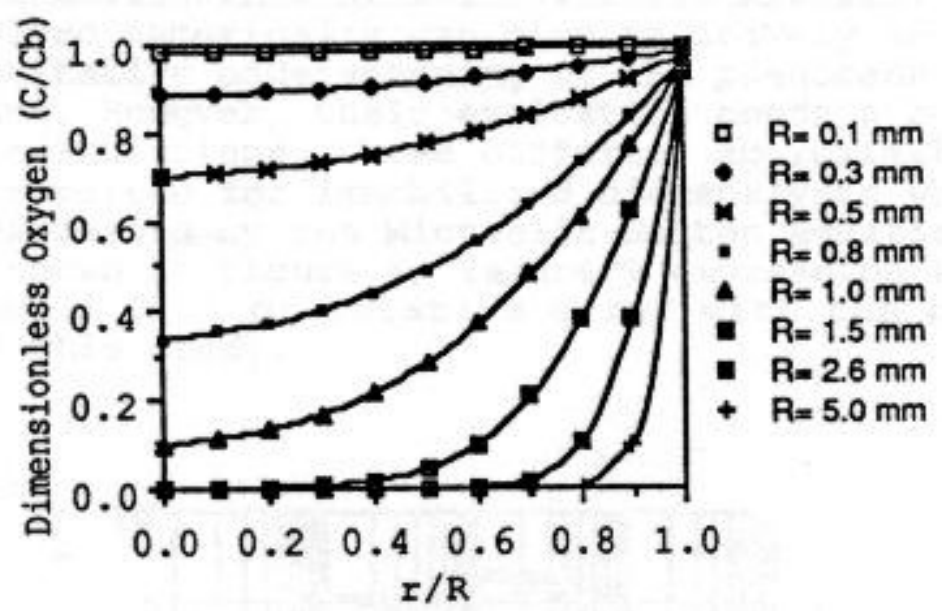

Figura 2.7 - Concentração relativa de $\mathrm{O}_{2}$ em função do raio relativo (KHANG et al, 1988). $C=$ concentração de $\mathrm{O}_{2}$ no raio $r, C_{b}=$ concentração de $\mathrm{O}_{2}$ na superfície da partícula, $R=$ raio da partícula esférica 


\subsection{Sistemas e reatores empregados.}

Os sistemas com células imobilizadas caracterizam-se pelo confinamento das células em alguma estrutura física, obrigando-as a permanecerem em uma região particular do reator. As técnicas de imobilização empregadas permitem a utilização de biorreatores de configurações diferenciadas do tradicional tanque agitado (STR), sendo a maior parte dos estudos aplicados em reatores do tipo colunas operadas continuamente, com leito fixo ou fluidizado das partículas com as células imobilizadas (PRADELLA, 2001).

Algumas das configurações dos biorreatores apresentados na literatura em estudos com células imobilizadas tanto em leito fixo como em fluidizado são descritos nos itens a seguir.

\subsubsection{Biorreator tipo cesta ("basked stirred tank reactor" - BSTR)}

Alguns trabalhos a respeito de processos com células imobilizadas apresentaram a utilização de uma cesta adaptada ao biorreator de tanque agitado (STR), com finalidade de que as pás de agitação do biorreator não tivessem contato com o suporte utilizado, não comprometendo, assim, a integridade deste ao longo dos cultivos. Algumas outras vantagens desse tipo de sistema referem-se à flexibilidade nos modos de operação e a facilidade do controle dos parâmetros operacionais (pH, agitação, OD). Os trabalhos de Gaite et al.(1988) e Tavares (1998) estudaram este tipo de sistema para a produção de etanol; por sua vez Abeyan et al. (1996) aplicou o reator tipo cesta para a produção de ácido láctico e Carvalho (2004) para a produção de xilitol.

Os géis que foram empregados na imobilização (alginato e pectina), em geral, apresentaram boa estabilidade neste tipo de sistema, apesar de serem relatados um significativo percentual de células livres no caldo fermentado, caracterizando assim um cultivo misto com células livres e imobilizadas.

As figuras 2.8.e 2.9, a seguir, ilustram os reatores tipo cesta, empregados nos trabalhos de Tavares (1998) e Carvalho (2004). 


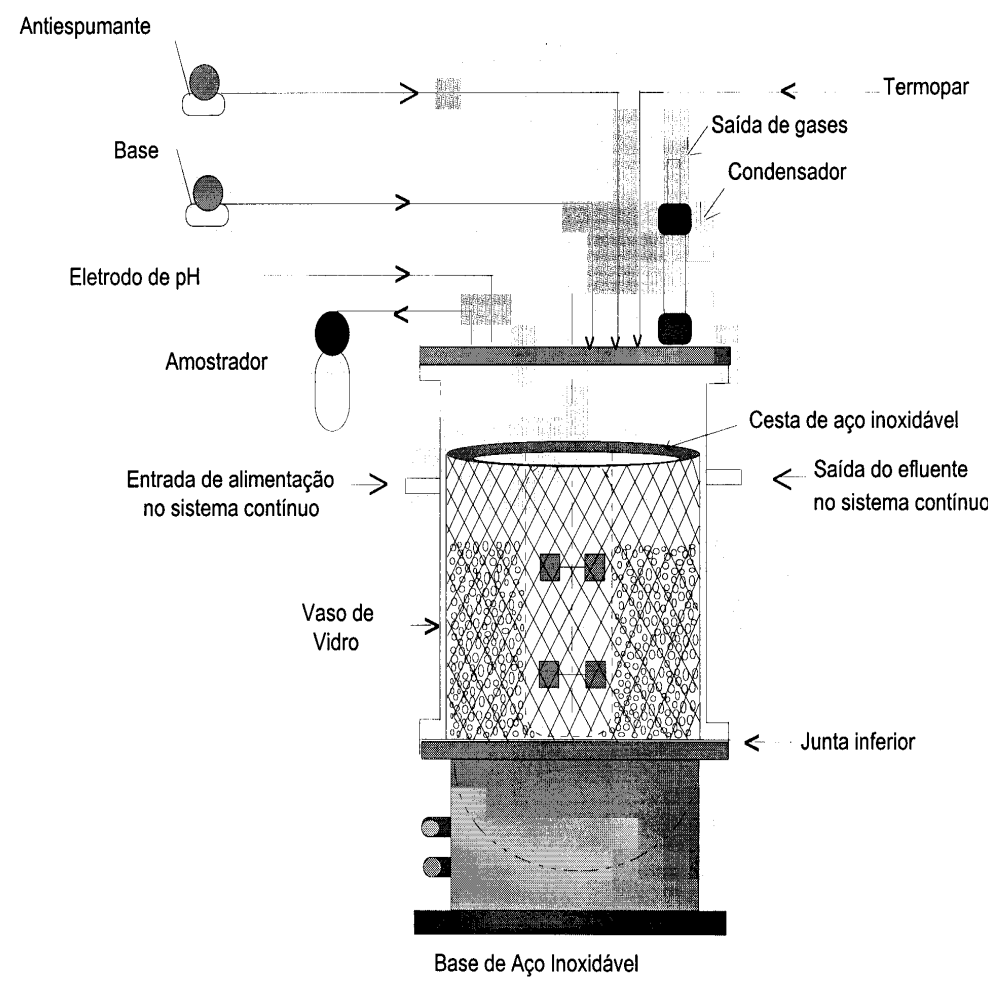

Figura 2.8 - Reator tipo cesta (TAVARES, 1998)

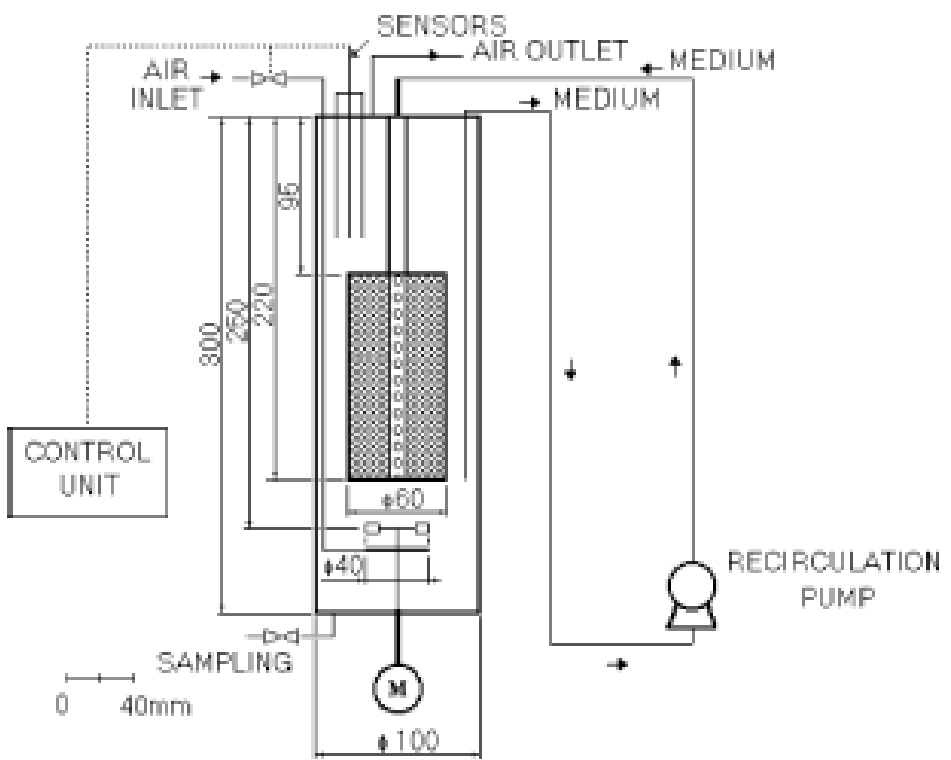

Figura 2.9 - Reator tipo cesta (CARVALHO, 2004) 


\subsubsection{Biorreator coluna de bolhas}

O biorreator coluna de bolhas, também denominado "tipo torre" (ARAÚJO et al., 1999; CRUZ et al., 2004; LAVARDA, 2003) é caracterizado pelo borbulhamento ascendente de gás e ausência de agitação mecânica, o que resulta em menores tensões de cisalhamento. Através da aplicação de altas vazões de aeração se consegue um transporte rápido e efetivo dos nutrientes no meio de cultivo. Os reatores tipo airlift, que se caracterizam pelos movimentos cíclicos do fluido através de arranjos internos, apresentam características similares ao reator coluna de bolhas e também têm sido objeto de estudo na literatura em processos com células livres e imobilizadas.

Estes tipos de reatores têm apresentado algumas vantagens em relação aos reatores de mistura (STR), tais como baixo custo inicial, configuração mecânica simples e reduzido custo operacional, com relação ao requerimento de energia por não possuir agitação mecânica. Uma importante área de aplicação das colunas de bolhas é a sua utilização para produção industrial de enzimas, proteínas, antibióticos (KANTARCl et al., 2005). Em processos com células imobilizadas as vantagens dizem respeito a facilitar a mistura e aeração no reator, diminuir a viscosidade do caldo fermentativo e permitir a utilização das células por longos períodos em operações contínuas ou semicontínuas, porém gera problemas de transferência de massa intraparticular que são objetos de estudo na literatura (KHANG et al., 1988; ARAUJO et al., 1996; ALMEIDA, 1999).

A Tabela 2.1 apresenta alguns estudos mais recentes que utilizaram reatores colunas de bolhas em processos biotecnológicos. 
Tabela 2.4 - Aplicações de biorreatores coluna de bolhas (adaptado de KANTARCl et al., 2005).

\begin{tabular}{ccc}
\hline Bioproduto & Microrganismo & Referência \\
\hline Etanol & Shaccharomyces cerevisae & Ogbonna et al., 2001 \\
Ácidos Orgânicos & Eubacterium limosum & Chang et al., 2001 \\
Anticorpos Monoclonais & Hybridoma cells & Rodrigues et al, 1999 \\
Glicoamilase & Aurebasidium pulluvans & Federici et al., 1990 \\
Cefalosporina C & C. acremonium & Cruzet al., 2004 \\
Degradação de fenol & Candida tropicallis & Juarez-Ramirez et al., 2001 \\
Taxol & Taxus & Son et al., 2000 \\
\hline
\end{tabular}

Exemplos de biorreatores colunas de bolhas aplicados em processos com células imobilizadas são ilustrados, a seguir, nas Figuras 2.10 a 2.12.

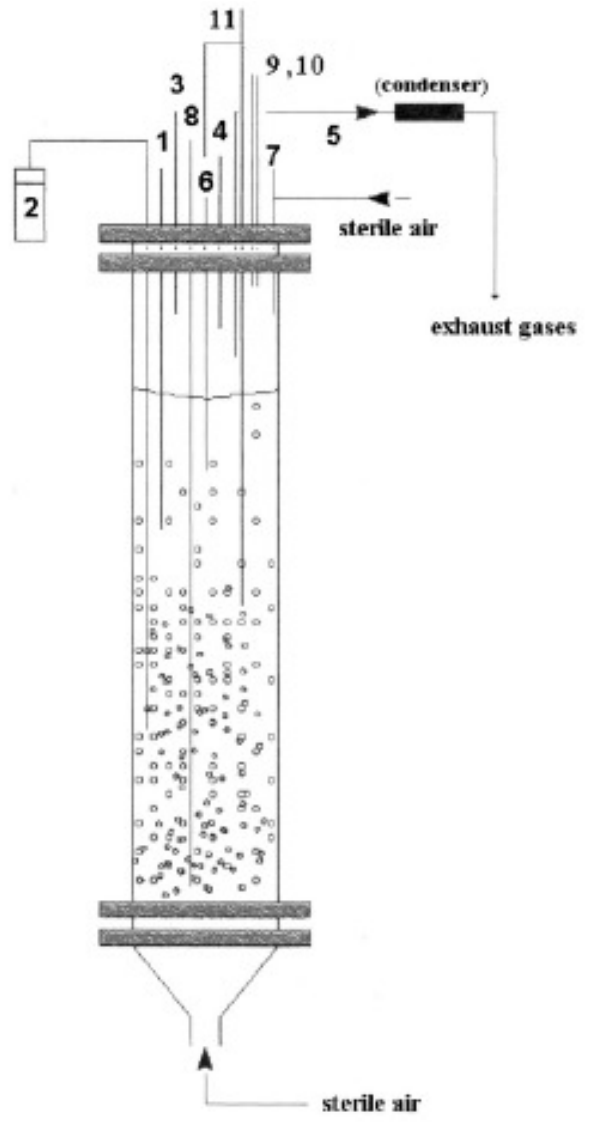

Figura 2.10 - Esquema do reator tipo torre utilizado na produção de cefalosporina C (CRUZ, 2004) 


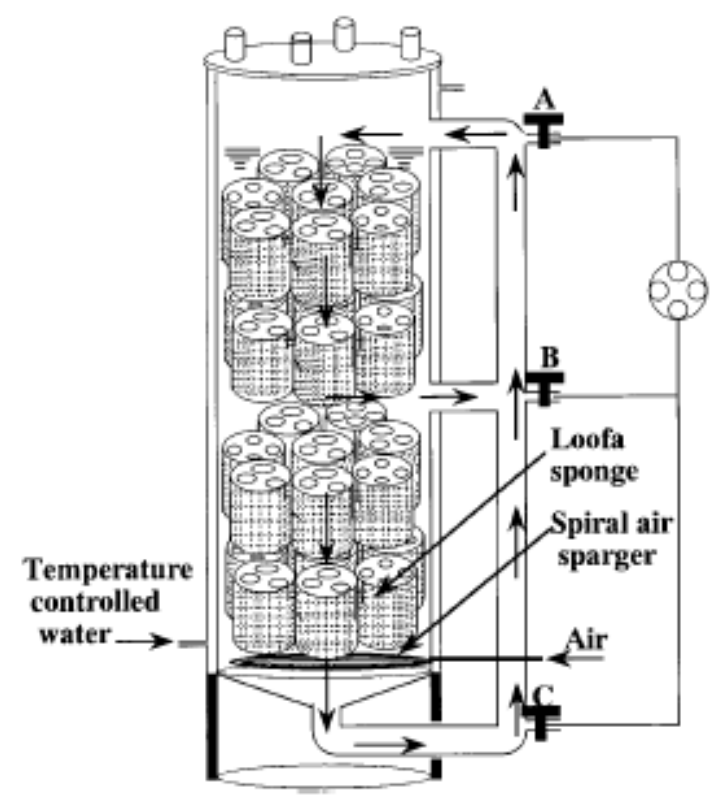

Figura 2.11 - Reator coluna de bolhas utilizado para produção de etanol com células imobilizadas em esponja (OGBONNA et al., 2001).

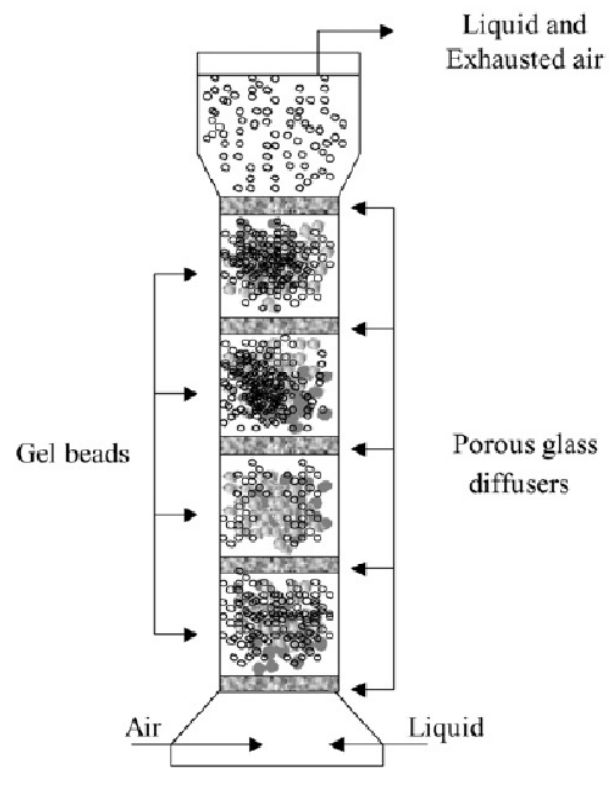

Figura 2.12 - Esquema do reator coluna de bolhas com células de Candida tropicallis imobilizadas em agar para degradação de fenol (JUAREZ-RAMIREZ et al., 2001)

Alguns dos trabalhos operados em leito fluidizado em diferentes formas de condução de processo são descritos a seguir. 
Sàrra et al. (1997) estudaram a utilização de pellets da linhagem modificada de Streptomyces lividans TK21 para a produção continua de um antibiótico híbrido em biorreator de leito fluidizado. Os autores observaram que os pellets foram mecanicamente estáveis no biorreator e foram capazes de produzir o antibiótico por um longo período de tempo. A produtividade específica do antibiótico produzido pelas células imobilizadas em biorreator de leito fluidizado foi 1,3 vezes maior do que aquela obtida a partir de células livres em biorreator convencional. A produção contínua do antibiótico híbrido foi feita separando-se o crescimento celular e a produção, através da limitação de fosfato no meio de cultivo, a uma vazão específica de alimentação de $0,021 \mathrm{~h}^{-1}$. A produção contínua durou 60 dias com níveis satisfatórios, e o biorreator operou de maneira estável por 85 dias.

Srinivasulu et al. (2003b) estudaram a produção de neomicina com células imobilizadas de Streptomyces marinensis NUV-5 em alginato de cálcio em 4 tipos de reatores (STR, leito fixo, leito fluidizado e airlift). Os reatores STR, airlift e leito fluidizado apresentaram uma produção similar ao reator STR com células livres, sendo que o airlift foi superior a este ultimo, provavelmente devido às altas taxas de aeração e difusão. Já o reator de leito fixo, apresentou uma baixa produção de neomicina, o que nos permite concluir que a produção de neomicina em biorreatores, com células imobilizadas, requer altos níveis de agitação e aeração.

Lavarda (2003) realizou estudos de imobilização de Streptomyces clavuligerus para produção de ácido clavulânico em biorreator tipo torre. Seus resultados indicaram a viabilidade do sistema com células imobilizadas, visto que foram obtidos níveis satisfatórios de produção do ácido clavulânico, em comparação com o sistema com células livres, assim como observou-se a manutenção da integridade das biopartículas. Quanto aos resultados a respeito do coeficiente volumétrico de transferência de oxigênio (Kla), os valores para os cultivos com células imobilizadas em gel de alginato mostraram-se superiores, quando comparados aos valores obtidos nos cultivos com células livres.

Cruz et al. (2004) estudaram a produção de cefalosporina C por células imobilizadas de Cephaslosporium acremonium ATCC 48272 em um biorreator tipo torre (coluna de bolhas) em bateladas repetidas. As maiores produtividades foram alcançadas durante a segunda batelada, quando a concentração celular estava alta, resultando em um rápido consumo de glicose, e logo após sua exaustão, a produção 
de cefalosporina C. Também foi observado que as células foram capazes de manter sua habilidade produtiva por um longo período.

\subsubsection{Propriedades fluidodinâmica dos biorreatores coluna de bolhas}

Apesar da simplicidade quanto à construção, a caracterização e o aumento de escala de biorreatores tipo torre (coluna de bolhas) são dificultados devido à complexidade dos fenômenos fluido-dinâmicos (ARAUJO et al., 1996).

Kantarci et al. (2005) descreveu três tipos de regimes de fluxo, em relação às propriedades fluidodinâmicas das colunas de bolhas: regime homogêneo, regime heterogêneo e o regime slug, como ilustra a figura 2.13.

O regime homogêneo é obtido com baixas velocidades superficiais do gás $(<5 \mathrm{~cm} / \mathrm{s})$; é caracterizado por bolhas pequenas com distribuição de tamanhos uniformes (bubble flow perfect) ou com pequenas variações (bubble flow imperfect) e não se observa o fenômeno de coalescência de bolhas.
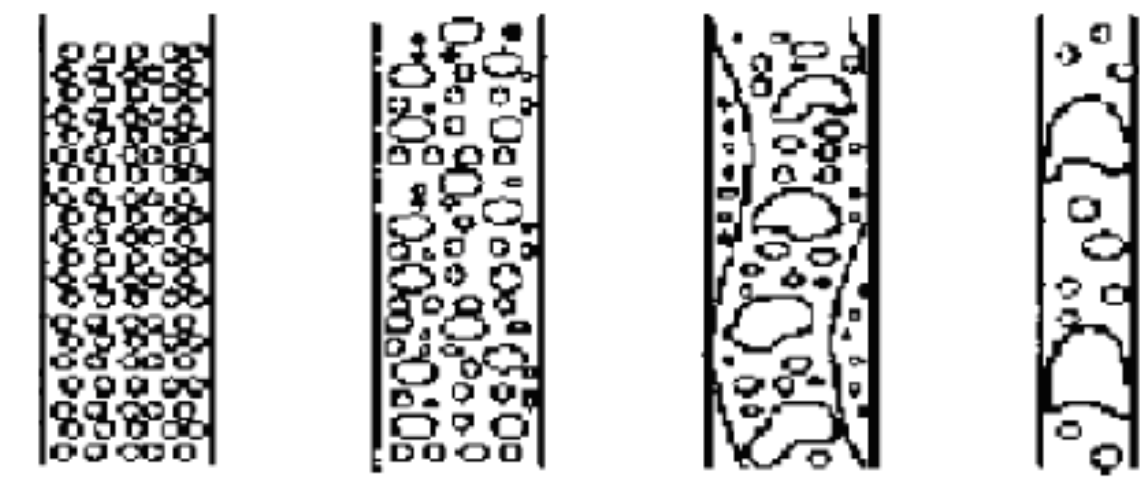

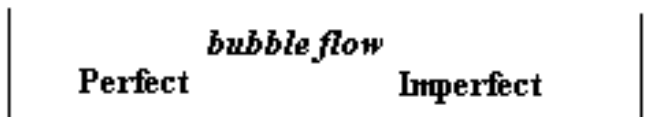

Homogêneo

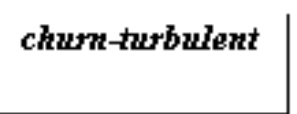

Heterogêneo

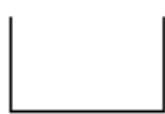

Slug flow

Figura 2.13 - Regimes de fluxo em colunas de bolhas (KANTARCl et al., 2005)

Por sua vez o regime heterogêneo, também chamado de turbulento é obtido com altas velocidades superficiais do gás $(>5 \mathrm{~cm} / \mathrm{s})$. Este regime pode ser caracterizado pelo aumento da turbulência no movimento das bolhas de gás e da 
recirculação do líquido. Neste regime é observada a formação da coalescência de bolhas e, conseqüentemente, a presença de bolhas de diferentes tamanhos, diminuindo neste caso a área de transferência do sistema gás-líquido. Este regime é observado em escala industrial para colunas de grandes diâmetros.

Por último tem-se o regime slug, o qual tem sido descrito para trabalhos em colunas de laboratório com pequenos diâmetros $(<15 \mathrm{~cm})$ e altas velocidades superficiais, e é caracterizado quando bolhas muito grandes são estabilizadas durante a trajetória da coluna.

A detecção da transição do regime de homogêneo para o regime turbulento ocorre quando mudanças significativas são observadas no comportamento hidrodinâmico do sistema, podendo-se observar o início da circulação líquida ascendente no centro da coluna e de circulação líquida descendente perto da parede da coluna.

As propriedades reológicas do líquido têm um grande impacto na formação da coalescência das bolhas, o qual é um grande problema para sistemas com processos biológicos que utilizam microrganismos filamentosos, já que o cultivo destes leva à formação de um sistema muito viscoso, prejudicando assim a solubilização do gás no líquido e, conseqüentemente, diminuindo a transferência de oxigênio. 


\section{MATERIAIS E MÉTODOS}

\subsection{Microrganismo}

A linhagem mutante de Streptomyces olindensis ICB20 utilizada nos cultivos, foi fornecida ao Laboratório de Engenharia Bioquímica do Departamento de Engenharia Química da Escola Politécnica da Universidade de São Paulo (LEB/DEQ/POLI/USP) pelo Laboratório de Genética de Microrganismos do Instituto de Ciências Biomédicas da USP (LG/ICB/USP). Esta linhagem foi obtida através de mutagênese química da cepa selvagem S. olindensis DAUFPE 5622, a qual foi fornecida pelo Departamento de Antibióticos da Universidade Federal de Pernambuco ao Laboratório de Genética de Microrganismos do ICB/USP. Dentre as características morfológicas desta linhagem mutante, destacam-se a perda de esporulação e a formação de micélios ramificados (FURLAN, 1997).

A cultura estoque foi mantida congelada sob a forma de micélio em glicerol $20 \% \mathrm{p} / \mathrm{v}$ em ultrafreezer a $-80^{\circ} \mathrm{C}$. Esta cultura foi obtida a partir de cultivos realizados em incubador rotativo, utilizando-se meio R5 modificado (R5Mod) (GUIMARÃES, 2005).

\subsection{Meio de cultura}

O meio de cultura líquido utilizado nas etapas de preparo do estoque, do préinóculo, do inóculo e nos ensaios em biorreator, foi o meio R5 modificado (R5MOD), empregado em trabalhos anteriores por Furlan (1997), Guimarães (2000) e Martins (2001), com a seguinte composição: 


$\begin{array}{ll}\text { Glicose } & 10,0 \mathrm{~g} / \mathrm{L} \\ \text { Extrato de levedura } & 5,0 \mathrm{~g} / \mathrm{L} \\ \text { Casaminoácidos } & 0,1 \mathrm{~g} / \mathrm{L} \\ \text { Tris(hidroximetil)aminometano } & 3,09 \mathrm{~g} / \mathrm{L} \\ \mathrm{K}_{2} \mathrm{SO}_{4} & 0,25 \mathrm{~g} / \mathrm{L} \\ \mathrm{MgCl}_{2} \cdot 6 \mathrm{H}_{2} \mathrm{O} & 10,12 \mathrm{~g} / \mathrm{L} \\ \mathrm{KH}_{2} \mathrm{PO}_{4} 0,5 \% \mathrm{p} / \mathrm{v} & 10,0 \mathrm{~mL} / \mathrm{L} \\ \mathrm{CaCl}_{2} 5 \mathrm{M} & 4,0 \mathrm{~mL} / \mathrm{L} \\ \text { Solução de elementos traço } & 2,0 \mathrm{~mL} / \mathrm{L}\end{array}$

Os nutrientes foram dissolvidos em água destilada e $\mathrm{opH}$ foi ajustado em aproximadamente 7,3 com solução de $\mathrm{HCl} 2 \mathrm{~N}$. Em seguida o meio foi autoclavado por 20 minutos a $120^{\circ} \mathrm{C}$.

As soluções de $\mathrm{CaCl}_{2}$ e $\mathrm{KH}_{2} \mathrm{PO}_{4}$ foram preparadas e autoclavadas por 20 minutos a $120 \stackrel{\circ}{ } \mathrm{C}$, enquanto que a solução de elementos traço foi esterilizada por filtração a vácuo em câmara de fluxo laminar, utilizando-se membrana com diâmetro de poro $0,2 \mu \mathrm{m}$.

A solução de elementos traço é composta por:

$\begin{array}{ll}\mathrm{ZnCl}_{2} & 40 \mathrm{mg} \\ \mathrm{CuCl}_{2} \cdot 2 \mathrm{H}_{2} \mathrm{O} & 10 \mathrm{mg} \\ \left(\mathrm{NH}_{4}\right)_{6} \mathrm{Mo}_{7} \mathrm{O}_{24} \cdot 4 \mathrm{H}_{2} \mathrm{O} & 10 \mathrm{mg} \\ \mathrm{FeCl}_{3} \cdot 6 \mathrm{H}_{2} \mathrm{O} & 200 \mathrm{mg} \\ \mathrm{MnCl}_{2} \cdot 4 \mathrm{H}_{2} \mathrm{O} & 10 \mathrm{mg} \\ \mathrm{Na}_{2} \mathrm{~B}_{4} \mathrm{O}_{7} \cdot 10 \mathrm{H}_{2} \mathrm{O} & 10 \mathrm{mg}\end{array}$

Pela sua composição, observa-se que o meio R5Mod é um meio complexo, contendo elevada concentração de extrato de levedura, fato que o torna oneroso e impróprio para utilização em escala industrial. Apesar disto, este meio foi utilizado no presente trabalho devido ao objetivo de se comparar o desempenho dos cultivos com células imobilizadas e com células livres (GUIMARÃES, 2000; MARTINS, 2001, PAMBOUKIAN, 2003; AZEVEDO, 2005). 


\subsection{Preparo do Estoque e Conservação da Cepa}

O preparo do estoque e a conservação da linhagem mutante ICB20 foram realizados de acordo com a metodologia definida por Guimarães (2000):

a) Erlenmeyers de $1000 \mathrm{~mL}$ contendo $90 \mathrm{~mL}$ de meio R5Mod, foram inoculados com $10 \mathrm{~mL}$ de células de $S$. olindensis ICB20 suspensas em glicerol e foram incubados em agitador rotativo, por 16 horas a $200 \mathrm{rpm}$ e $30^{\circ} \mathrm{C}$;

b) Os conteúdos de todos os erlenmeyers foram transferidos para um único erlenmeyer e $50 \mathrm{~mL}$ desta suspensão de células foram transferidas para frascos de $2000 \mathrm{~mL}$, contendo $450 \mathrm{~mL}$ de meio R5Mod;

c) Os frascos foram incubados em incubador rotativo, por 24 horas a $30^{\circ} \mathrm{C}$ e 200 rpm;

d) Após esse período de incubação, as células foram lavadas com solução salina e centrifugadas a $3700 \mathrm{~g}$ para então serem ressuspensas em solução de glicerol $20 \%$ $(\mathrm{p} / \mathrm{v})$;

e) As células foram armazenadas a $-80^{\circ} \mathrm{C}$, em tubos cônicos contendo $10 \mathrm{~mL}$ de células cada.

\subsection{Condições dos ensaios realizados}

\subsubsection{Reativação do micélio}

Em frascos erlenmeyers de $1000 \mathrm{~mL}$, inocularam-se $10 \mathrm{~mL}$ de suspensão de micélio congelado em $90 \mathrm{~mL}$ de meio R5Mod. Os frascos foram mantidos a $30^{\circ} \mathrm{C}$, durante 16 horas, sob freqüência de agitação de 200 rpm (GUIMARÃES, 2000). 


\subsubsection{Cultivo pré-imobilização}

a) Foram inoculados erlenmeyers de $1000 \mathrm{~mL}$, contendo $180 \mathrm{~mL}$ de meio R5Mod cada um, com $20 \mathrm{~mL}$ de células provenientes da reativação do micélio (item 3.4.1);

b) Os erlenmeyers foram cultivados em incubador rotativo a $30^{\circ} \mathrm{C}$ e $200 \mathrm{rpm}$ por 48 horas, período após o qual se obtém a máxima concentração celular, cerca de 3,5 g de células por litro de caldo fermentado (AZEVEDO, 2005).

\subsubsection{Imobilização das células}

O procedimento para a imobilização das células de $S$. olindensis teve como referência o trabalho de Azevedo (2005), conforme descrito a seguir.

a) Após o cultivo pré-imobilização (item 3.4.2), o inóculo foi centrifugado a $3700 \mathrm{~g}$ por 20 min e $4^{\circ} \mathrm{C}$. As células coletadas foram ressuspensas em solução de alginato de sódio 3\% (Synth), esterilizada previamente por autoclavagem (121 ำ, 20 minutos);

b) Em seguida, a suspensão foi homogeneizada e gotejada, em uma solução de $\mathrm{CaCl}_{2} 0,2 \mathrm{M}$, através de um sistema adaptado a uma bomba peristáltica, a uma vazão de 10,5 mL/ min, utilizando-se agulhas de 1,2 mm de diâmetro. As partículas formadas foram mantidas por $24 \mathrm{~h}$ (tempo de cura) sob refrigeração, para permitir uma maior agregação do íon cálcio às partículas do gel, dando-lhes maior resistência e compressividade. O tamanho da esfera formada foi em torno de $3 \mathrm{~mm}$, diâmetro este definido anteriormente no trabalho de Azevedo (2005);

c) Após o tempo de cura, as partículas de alginato de cálcio com células imobilizadas foram transferidas, assepticamente, para o reator. A proporção de volume de gel/volume de meio utilizada foi de 1/3 em todos os ensaios.

No início deste trabalho, a determinação do diâmetro das esferas de alginato de Cálcio foi realizada, após o tempo de cura, através de análise de imagens 
fotográficas (Figura 3.1), utilizando-se o analisador LEICA Q550IW e o software LEICA QWin . Através de uma sub-rotina, o software consegue distinguir as partículas e fazer a medição de diâmetro (PAMBOUKIAN, 2003).

$O$ diâmetro médio do gel foi em torno de $3,00 \mathrm{~mm} \pm 0,2$ e sua integridade durante os cultivos foi acompanhada por observações microscópicas. Segundo Azevedo (2005), o diâmetro do gel não apresentou mudanças significativas ao longo dos cultivos em incubador rotativo.

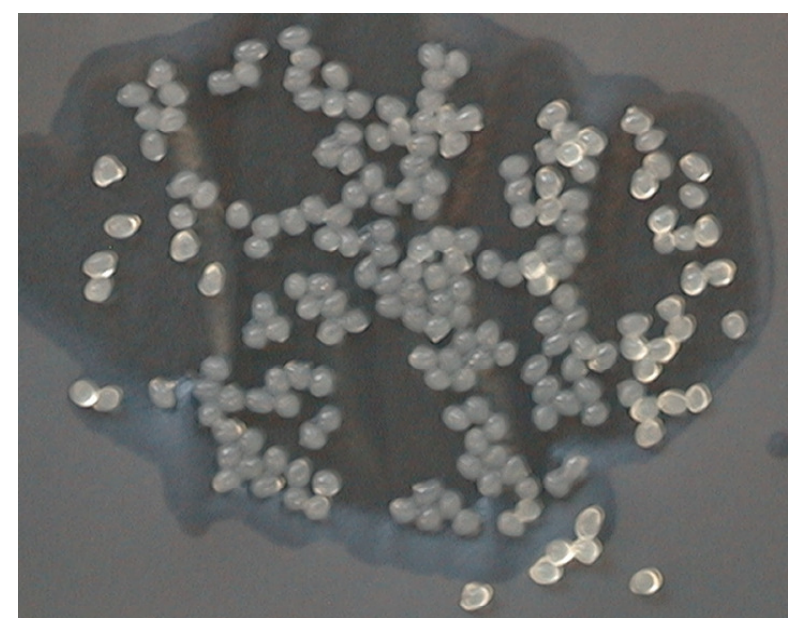

Figura 3.1 - Partículas de alginato de sódio (AZEVEDO, 2005)

\subsubsection{Cultivos em biorreator tipo cesta}

\subsubsection{Descrição do biorreator tipo cesta}

O biorreator tipo cesta foi obtido a partir da adaptação de um reator Bioflo III, através da introdução de uma cesta com tela de aço inoxidável (Figura 3.2), contendo no seu interior as células imobilizadas em gel de alginato (Figura 3.3).

O biorreator tipo cesta permite a utilização do sistema de agitação e aeração do próprio reator e não há um contato direto das pás do agitador mecânico com as esferas, o que poderia causar alto cisalhamento e rompimento das esferas. Além 
disso, é possível empregar-se os demais sistemas de controle dos reatores convencionais, tais como temperatura, $\mathrm{pH}$ e oxigênio dissolvido (TAVARES, 1998).

A descrição do Biorreator (Figura 3.2) encontra-se detalhada a seguir:

- Biorreator BIOFLOIII (New Brunswick Scientific Co.), de $3 \mathrm{~L}$ de capacidade e 2,4 L de volume útil (altura do reator: $25 \mathrm{~cm}$; diâmetro do tanque: $13,5 \mathrm{~cm}$; altura do tanque: $25 \mathrm{~cm}$ ).

- Cesta de tela de aço inoxidável (Figura 3.2): formato cilíndrico com $21 \mathrm{~cm}$ de altura, $13 \mathrm{~cm}$ de diâmetro externo e $8 \mathrm{~cm}$ de diâmetro interno; tamanho da malha de aço inoxidável: $2 \mathrm{~mm}$.

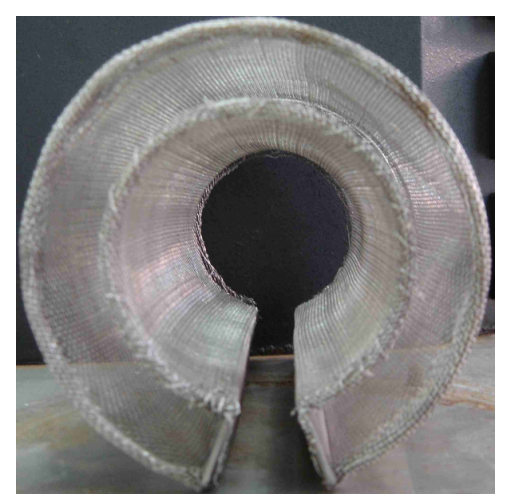

Figura 3.2 - Cesta de aço inoxidável

Para a realização dos ensaios, o biorreator foi esterilizado em autoclave a $120^{\circ} \mathrm{C}$ durante 30 minutos, contendo 1,8 litros de meio R5Mod (as concentrações dos nutrientes foram calculadas para o volume total de 2,4 litros). A cesta foi esterilizada em autoclave separadamente do biorreator, e após a esterilização, foi preenchida, assepticamente, com $600 \mathrm{~mL}$ das esferas de alginato contendo as células imobilizadas, e em seguida introduzida no reator. A solução de glicose (esterilizada separadamente) foi adicionada ao reator, juntamente com as soluções de $\mathrm{KH}_{2} \mathrm{PO}_{4}, \mathrm{CaCl}_{2}$ e solução de elementos traço. Todas estas etapas foram realizadas em câmara de fluxo laminar e, em seguida, o reator foi levado ao gabinete do Bioflo III para dar-se início ao ensaio. Todos os cultivos realizados não tiveram controle de $\mathrm{pH}$, devido à dificuldade de utilização do eletrodo de $\mathrm{pH}$ para a configuração do biorreator tipo cesta. Porém, apesar da ausência do controle, 
constatou-se em todos os ensaios realizados com células imobilizadas, uma variação muito pequena de $\mathrm{pH}$ durante os cultivos (cerca de 7,0 $\pm 0,2$ ).

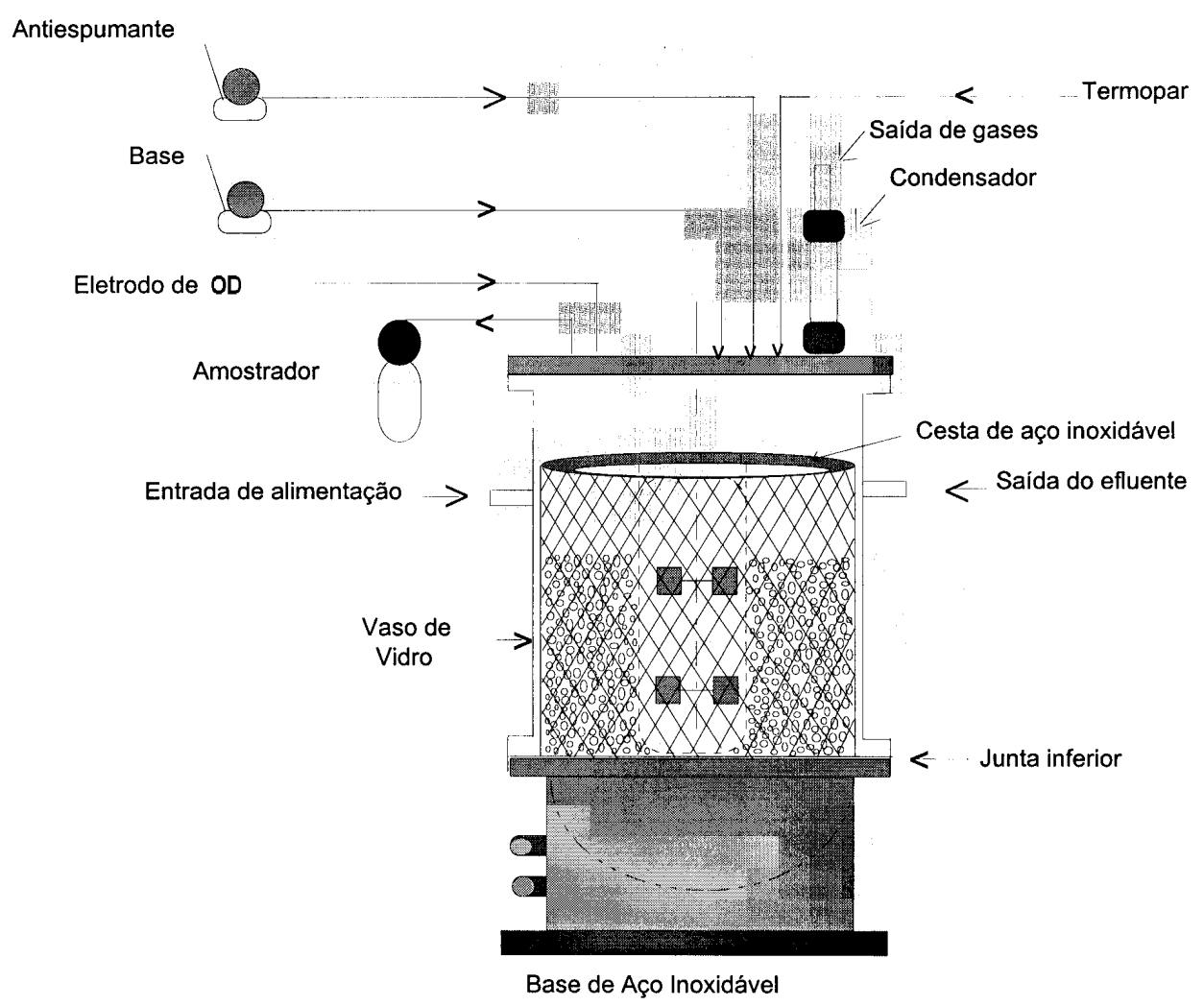

Figura 3.3 - Esquema do biorreator tipo cesta (TAVARES, 1998)

A retirada de amostra do biorreator, para as determinações analíticas, foi realizada efetuando-se o seguinte procedimento:

a) Diminuía-se a freqüência de agitação do biorreator (100 rpm);

b) Abria-se, com cuidados de assepsia, a tampa rosqueada do biorreator;

c) Introduzia-se, com cuidados de assepsia, uma pipeta de $25 \mathrm{~mL}$ sem ponta, para retirada de cerca de $20 \mathrm{~mL}$ de amostra de gel juntamente com o meio líquido.

d) Fechava-se o orifício e estabelecia-se novamente a freqüência de agitação do ensaio.

Todo este procedimento de retirada de amostra levava cerca de alguns minutos. Apesar de todos os devidos cuidados de assepsia, alguns ensaios foram contaminados nesta etapa de retirada de amostra, principalmente no início dos cultivos. 


\subsubsection{Cultivos em batelada simples no biorreator tipo cesta com células livres e imobilizadas.}

Foram realizados alguns ensaios em bateladas simples, visando o estudo da influência de diferentes condições de transferência de oxigênio, a fim de estabelecer a melhor condição de agitação e aeração no cultivo em biorreator tipo cesta, que por sua vez, foi a condição empregada nos cultivos em bateladas repetidas e contínuos.

As condições empregadas nos ensaios descontínuos encontram-se descritas na tabela 3.1, a seguir:

Tabela 3.1 - Condições dos ensaios descontínuos no reator tipo cesta

\begin{tabular}{|c|c|c|c|c|}
\hline Ensaio & $\begin{array}{c}\text { Freqüência de } \\
\text { agitação }(\mathbf{r p m})\end{array}$ & $\begin{array}{c}\text { Temperatura } \\
(\mathbf{o} \mathbf{C})\end{array}$ & $\begin{array}{c}\text { Aeração } \\
\left(\mathbf{v v m}^{\star}\right)\end{array}$ & $\begin{array}{c}\text { Controle de } \\
\text { Oxigênio dissolvido (OD) }\end{array}$ \\
\hline SI-500 & 500 & 30 & 1 & Sem controle \\
\hline SI-300 & 300 & 30 & 1 & Sem controle \\
\hline SI-300-80 & 300 & 30 & 0,4 & $\begin{array}{c}\text { Controlado em } 80 \% \\
\text { (adição de } \mathrm{O}_{2} \text { à entrada } \\
\text { de gases do reator) }\end{array}$ \\
\hline SL-500 & 500 & 30 & 1 & Sem controle \\
\hline
\end{tabular}

SI: Ensaio com células imobilizadas

SL: Ensaio com células livres

* vvm: Volume de ar por volume de meio por minuto

O ensaio SI-300-80, que foi realizado com uma vazão de aeração de 0,4 vvm, teve também como objetivo tentar medir a respiração celular, através da realização de balanço gasoso no reator, tendo em vista que o analisador de gases da utilizado (New Brunswick Scientific Co) não apresentou sensibilidade nas medidas de oxigênio e gás carbônico para a condição de 1 vvm de aeração aplicada nos experimentos anteriores a este. Os resultados do balanço gasoso, assim como a metodologia empregada, encontram-se apresentados no Apêndice B.

Tentou-se realizar um ensaio com freqüência de agitação de 700 rpm, porém esta condição não foi viável, pois a maior freqüência de agitação levou o gel a se deslocar para fora da cesta, já que esta não era fechada na parte superior. 
A fim de se comparar o desempenho das células livres com as imobilizadas, foi realizado um ensaio com as células livres (SL-500), empregando-se as mesmas condições de cultivo que foram definidas para o ensaio SI-500, com células imobilizadas, no biorreator Bioflo II, sem a cesta de aço inoxidável e com controle de $\mathrm{pH}$.

\subsubsection{Cultivos em bateladas repetidas no biorreator cesta com células imobilizadas}

Após a definição da melhor condição de agitação e aeração dos ensaios descontínuos, $500 \mathrm{rpm}$ e $1 \mathrm{vvm}$, respectivamente, foram realizados dois ensaios em bateladas repetidas (SI-BR1 e SI-BR2). Estes se diferenciaram apenas pela concentração inicial de células. O início dos ensaios SI-BR1 e SI-BR2 obedeceu ao procedimento descrito anteriormente e após o término de uma batelada, o meio de cultura foi drenado com auxílio de uma mangueira acoplada a uma bomba peristáltica. Em seguida fez-se a reposição de meio de cultivo. O tempo para o término de cada batelada foi determinado de acordo com a verificação da escassez da glicose presente no meio e com a estabilização da medida da produção da retamicina.

\subsubsection{Cultivos contínuos no biorreator tipo cesta com células imobilizadas}

Os ensaios contínuos foram realizados empregando-se as mesmas condições de agitação e aeração utilizadas no ensaio descontínuo SI-500 (500 rpm e 1 vvm). Foi empregada a vazão específica de alimentação do meio de cultura $D=0,05 \mathrm{~h}^{-1}$ nos ensaios $\mathrm{Cl}-005-30$ e $\mathrm{Cl}-005-72$, e $\mathrm{D}=0,2 \mathrm{~h}^{-1}$ no ensaio $\mathrm{Cl}-02-30$.

O início do processo contínuo foi efetuado após a realização de uma etapa de cultivo descontínuo, cuja duração foi definida a partir das cinéticas apresentadas nos cultivos descontínuos. Primeiramente escolheu-se o instante correspondente ao final da fase de crescimento celular. Porém, observou-se que, após o início da 
alimentação, ocorreu acúmulo de glicose no meio de cultivo, e por isso, realizou-se o ensaio $\mathrm{Cl}-005-72$, no qual se iniciou a fase contínua após a observação do esgotamento da glicose.

As comparações dos ensaios contínuos com células imobilizadas utilizarão como referência os resultados com células livres obtidos no trabalho de Pamboukian (2003).

\subsubsection{Cultivos em biorreator coluna de bolhas}

\subsubsection{Descrição do biorreator coluna de bolhas}

O biorreator coluna de bolhas (Figura 3.3) empregado neste trabalho foi elaborado com base no trabalho de Lavarda (2003). O Financiamento para sua confecção contou com recursos de projeto FAPESP de auxílio à pesquisa ("Produção da retamicina com células imobilizadas") e foi construída pela empresa FGG Equipamentos e Vidraria de Laboratório Ltda. A coluna possui 2,5 L de capacidade e 2,0 L de volume útil.

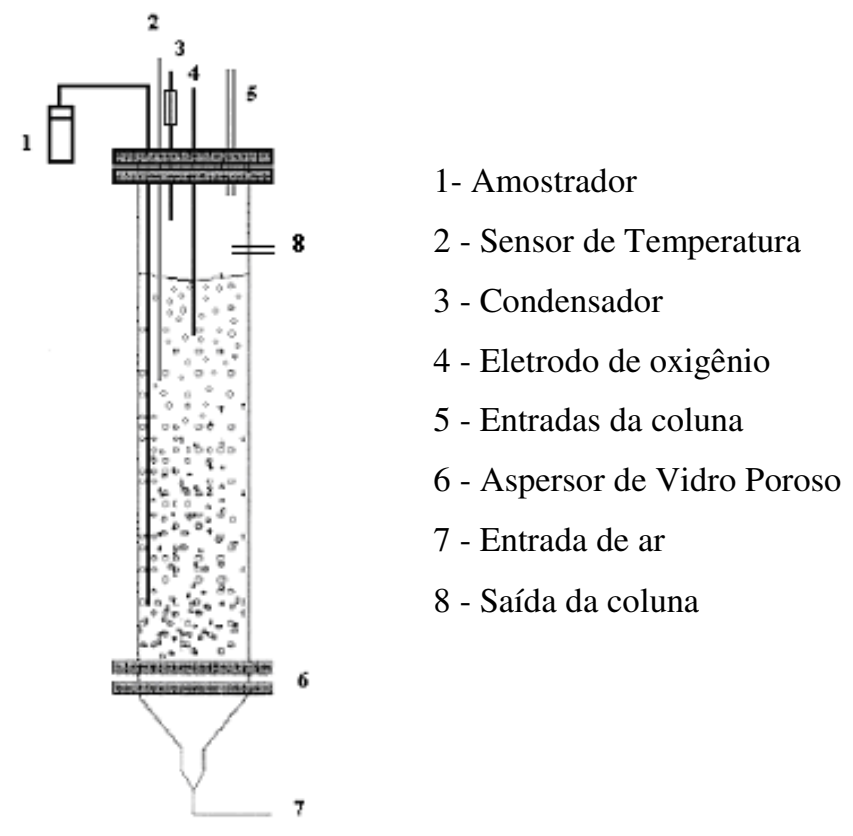

Figura 3.4 - Biorreator Coluna de Bolhas $\left(\phi_{\text {interno }}=8 \mathrm{~cm}\right.$; altura $=56 \mathrm{~cm}$; Volume útil $\left.=1,6 \mathrm{~L}\right)$ 
O aspersor utilizado foi do tipo vidro poroso com diâmetro de $5 \mathrm{~cm}$, o qual proporcionou uma boa distribuição do gás, de forma homogênea, com bolhas em torno de $3 \mathrm{~mm}$ de diâmetro. A operação da coluna foi realizada através dos dispositivos da cabine do reator Bioflo III (New Brunswick Scientific Co.), empregado nos ensaios anteriores (item 3.4.4), e temperatura foi controlada através da passagem de água pela camisa do biorreator.

Inicialmente foram realizados alguns ensaios na coluna para teste das conexões, verificação de vazamentos de ar e do volume de trabalho. Optou-se, então, por se utilizar um volume de trabalho 1,6 Litros, tendo em vista que seriam realizados ensaios sob alta vazão de aeração, o que poderia provocar uma expansão excessiva do volume de cultivo (holdup) e também formação de espuma.

A retirada de amostras do meio fermentado da coluna foi realizada pelo amostrador (Figura 3.4), sendo que para a retirada de amostra de meio com gel foi necessária a utilização de uma pipeta, como descrito anteriormente para o biorreator cesta.

\subsubsection{Cultivos descontínuos com células livres e imobilizadas em biorreator coluna de bolhas}

Foram realizados 3 cultivos com células livres (LC) e 3 cultivos com células imobilizadas (IC), em diferentes condições de aeração, sob temperatura constante de $30 \stackrel{\circ}{ } \mathrm{C}$, com o objetivo de comparar o desempenho dos sistemas nas diferentes vazões de aeração, e também de comparar com os resultados anteriores com células imobilizadas e livres (item 3.4.4.2). A tabela 3.2 a seguir descreve as condições dos ensaios:

Os ensaios com células livres (LC) foram iniciados após a esterilização da coluna, contendo $1440 \mathrm{~mL}$ do meio R5Mod, por 20 minutos e adicionando-se posteriormente $160 \mathrm{~mL}$ de cultivo pré-imobilização, juntamente com as soluções de $\mathrm{CaCl}_{2}, \mathrm{KH}_{2} \mathrm{PO}_{4}$ e elementos traço, mantendo-se assim a proporção de inóculo definido em trabalhos anteriores com células livres (GUIMARÃES, 2000). 
Tabela 3.2 - Condições dos ensaios no biorreator coluna de bolhas

\begin{tabular}{|c|c|}
\hline Ensaio & Condição \\
\hline IC1 & Células imobilizadas - $1 \mathrm{vvm}^{\star}$ \\
\hline IC2 & Células imobilizadas - $2 v v m^{*}$ \\
\hline IC3 & Células imobilizadas - $3 \mathrm{vvm}$ \\
\hline LC1 & Células livres - 1 vvm* \\
\hline LC2 & Células livres - 2 vvm* \\
\hline LC3 & Células livres - 3 vvm* \\
\hline
\end{tabular}

Para a realização dos ensaios com células imobilizadas (IC), a coluna foi esterilizada com volume de meio de $1200 \mathrm{~mL}$ (concentrações do meio calculadas para o volume total de $1600 \mathrm{~mL}$ ); em seguida $400 \mathrm{~mL}$ do gel de alginato, proveniente da etapa de imobilização, foi introduzido na coluna em câmera de fluxo laminar, mantendo-se assim, a proporção de 1/3 entre o volume de gel e volume de meio de cultivo, a mesma empregada no biorreator tipo cesta.

\subsubsection{Cultivos em bateladas repetidas com células imobilizadas em biorreator coluna de bolhas}

Foi realizado um experimento em sistema de bateladas repetidas empregando-se vazão de aeração de $2 \mathrm{vvm}$ (condição determinada a partir dos experimentos realizados na etapa anterior - item 3.4.5.2) e temperatura de $30^{\circ} \mathrm{C}$. A coluna foi adaptada com um tubo de aço que atingia a base da coluna, através do qual foi realizada a retirada de meio de cultivo ao final das bateladas. A determinação da concentração de células imobilizadas foi efetuada apenas no final de cada batelada a fim de evitar maiores riscos de contaminação. 


\subsubsection{Cultivos contínuos com células imobilizadas biorreator coluna de bolhas}

Foram realizados dois cultivos contínuos no biorreator coluna de bolhas, empregando-se vazão de aeração de $2 \mathrm{vvm}$ e temperatura de $30^{\circ} \mathrm{C}$. No primeiro ensaio contínuo (ICC1) foram aplicadas duas vazões específicas de alimentação do meio de cultura, $D=0,05 \mathrm{~h}^{-1}$ e $0,018 \mathrm{~h}^{-1}$. Estas vazões específicas de alimentação foram definidas com base nos trabalhos de Lavarda (2003) e Srinivasulu (2002), os quais observaram que a maior produção de metabólitos secundários, com células imobilizadas em biorreator coluna de bolhas, foi obtida com vazões menores que $0,05 \mathrm{~h}^{-1}$. O início do processo contínuo foi efetuado após a realização de uma etapa de cultivo descontínuo, iniciando-se a alimentação após o esgotamento da glicose.

O segundo cultivo contínuo (ICC2) foi realizado com uma vazão específica de alimentação de $0,03 \mathrm{~h}^{-1}$, vazão esta intermediária às vazões anteriores, a qual foi definida com base nos resultados do ensaio IC-C1, conforme será descrito no item 4.2.5.

\subsection{Determinações analíticas}

Todos os ensaios realizados foram acompanhados através da retirada periódica de amostras, nas quais fez-se uso das determinações analíticas descritas a seguir.

\subsubsection{Concentração celular livre}

A determinação da massa seca de células livres no meio de cultivo era efetuada após a filtração de uma amostra do meio de cultura de cerca de $15 \mathrm{~g}$, em 
membrana Millipore de 1,2 $\mu \mathrm{m}$, secagem em forno de microondas até massa constante (potência de $180 \mathrm{~W}$ por $15 \mathrm{~min}$ ) e pesagem.

Calculou-se a concentração de células livres pela seguinte equação:

$\mathrm{X}_{\mathrm{M}}=\frac{\text { massa seca de células }}{\text { volume da amostra }}=\frac{M s t-M m s}{M a} * d$

Onde:

$X_{M}=$ concentração de células livres no meio de cultivo ( $\left.g / L\right)$

$M_{\mathrm{st}}=$ massa seca total (células + membrana) $(\mathrm{g})$

$\mathrm{M}_{\mathrm{ms}}=$ massa membrana seca $(\mathrm{g})$

$\mathrm{M}_{\mathrm{a}}=$ massa da amostra $(\mathrm{g})$

$\mathrm{d}=$ densidade da amostra (considerada $1000 \mathrm{~g} / \mathrm{L}$ )

\subsubsection{Concentração celular imobilizada}

A determinação da concentração de células imobilizadas foi realizada de acordo com a metodologia adotada por Azevedo (2005), a qual se baseou nos trabalhos de Tavares (1998) e Srinivasulu (2003):

a) Após a retirada da amostra do gel do reator, conforme descrito anteriormente (itens 3.4.4.1 e 3.4.5.1), pesou-se cerca de 1 grama de partículas, previamente lavadas com água destilada e secas em papel absorvente.

b) Essas partículas foram colocadas em um erlenmeyer de $125 \mathrm{~mL}$, contendo $20 \mathrm{~mL}$ de solução tampão (Hexametafosfato de sódio-2\% p/v), aquecido previamente a uma temperatura de aproximadamente $40{ }^{\circ} \mathrm{C}$ e, em seguida, a mistura foi deixada sob agitação com agitador magnético, à temperatura ambiente, por 30 minutos;

c) A solução foi centrifugada a $3700 \mathrm{~g}$ por 20 minutos, descartou-se o sobrenadante, lavou-se as células com água destilada e centrifugou-se novamente sob a mesma condição anterior; 
d) Após a centrifugação a suspensão foi filtrada em membrana Millipore de 1,2 $\mu \mathrm{m}$, seca em forno de microondas até massa constante $(20 \%$ da potência máxima por 15 min) e posteriormente pesada.

O cálculo para a determinação da concentração celular imobilizada em termos de massa de células por volume de gel de alginato foi realizado pela seguinte equação:

$\mathrm{X}_{\mathrm{I}}=\frac{\text { massa seca total de células }}{\text { massa de gel }}=\frac{M s t-M m s}{M a} * d$

Onde:

$\mathrm{X}_{\mathrm{I}}$ : Concentração celular imobilizada ( $\mathrm{g} / \mathrm{L}$ de gel)

$\mathrm{M}_{\mathrm{ST}}=$ massa seca total (células + membrana) $(\mathrm{g})$

$\mathrm{M}_{\mathrm{ms}}=$ massa membrana seca $(\mathrm{g})$

$\mathrm{M}_{\mathrm{a}}=$ massa da amostra do gel $\left(\mathrm{g}_{\mathrm{gel}}\right)$

$\mathrm{d}=$ densidade do gel (considerada $1000 \mathrm{~g} / \mathrm{L}$ )

A concentração total de células no reator $\left(X_{T}\right)$, para cada instante de amostragem, foi determinada de acordo com as equações:

$$
\begin{aligned}
& X_{T}=X_{I, R}+X_{M, R} \\
& X_{I, R}=X_{I} \cdot \frac{V_{g e l}}{V_{R}} \\
& X_{M, R}=X_{M} \cdot \frac{V_{M}}{V_{R}}
\end{aligned}
$$

Onde:

$X_{M, R}$ : concentração de células livres por volume de reator $(g / L)$;

$\mathrm{X}_{\mathrm{M}}$ : concentração de células livres no meio de cultivo $(\mathrm{g} / \mathrm{L})$;

$\mathrm{V}_{\mathrm{M}}$ : é o volume de meio líquido no reator $(\mathrm{L})$;

$V_{R}$ : é o volume útil do reator $(L)$;

$X_{1}$ : Concentração celular imobilizada ( $\mathrm{g} / \mathrm{L}$ de gel);

$\mathrm{X}_{\mathrm{I}, \mathrm{R}}$ : Concentração de células imobilizadas por volume de reator $(\mathrm{g} / \mathrm{L})$;

$\mathrm{V}_{\text {gel }}$ : volume de gel no reator $(\mathrm{L})$;

$\mathrm{X}_{\mathrm{T}}$ : Concentração total de células no reator $(\mathrm{g} / \mathrm{L})$. 


\subsubsection{Concentração residual de glicose}

A dosagem da glicose foi realizada a partir do método enzimático da glicoseoxidase, implantado em um equipamento Technicon Auto-Analyser II, utilizando-se um conjunto de reagentes denominado Glucose Enzymatique Color Liquide (MERCK).

O princípio do método é baseado em técnicas colorimétricas, sendo descrito por Baham; Trinder (1972). Inicialmente, a amostra a ser analisada passa por uma membrana onde é realizada uma diálise, a fim de se eliminar macromoléculas que possam interferir na análise. A glicose que passa pela membrana é oxidada a ácido glicônico e peróxido de hidrogênio em presença de glicose-oxidase, segundo a seguinte reação:

$$
\text { Glicose }+\mathrm{O}_{2}+\mathrm{H}_{2} \mathrm{O} \longrightarrow \quad \text { ácido glicônico }+\mathrm{H}_{2} \mathrm{O}_{2}
$$

O peróxido de hidrogênio, na presença de peroxidase, oxida uma ou mais substâncias aceptoras de oxigênio, com a formação de um cromógeno vermelho, segundo a seguinte reação:

$$
\mathrm{H}_{2} \mathrm{O}_{2}+\text { Aceptor de Oxigênio } \longrightarrow \quad \text { Cromógeno vermelho }
$$

Existem vários sistemas que podem atuar como aceptor de oxigênio nesta reação. O mais empregado é o sistema que utiliza fenol e 4-aminofenazona. Estas duas substâncias reagem entre si, na presença de peróxido de hidrogênio e peroxidase, formando um cromógeno vermelho, a 4-p-benzoquinona-monoimino fenazona. A concentração desta substância, determinada por métodos colorimétricos, é proporcional à concentração de glicose na amostra.

A curva de calibração foi obtida, utilizando-se soluções padronizadas de glicose com concentrações entre $0,2 \mathrm{~g} / \mathrm{L}$ e $1,0 \mathrm{~g} / \mathrm{L}$, relacionando a concentração de cromógeno com a concentração de glicose presente na amostra.

O acompanhamento da concentração de glicose durante os cultivos também foi realizado utilizando o aparelho Advantage II (Produto Roche Químicos e Farmacêuticos S.A.), utilizado comumente por diabéticos para controle do açúcar presente no sangue, por apresentar resultados muito rápidos. Este acompanhamento foi importante nos cultivos em bateladas repetidas e nos cultivos contínuos, indicando o momento de esgotamento da glicose no meio. 


\subsubsection{Produção de retamicina no meio}

A determinação da concentração de retamicina, durante os cultivos, foi realizada a partir de metodologia desenvolvida por Guimarães (2000), como descrita a seguir:

a) Retirou-se uma alíquota de $5 \mathrm{~mL}$ do filtrado ou sobrenadante e transferiu-se para um béquer de $10 \mathrm{~mL}$;

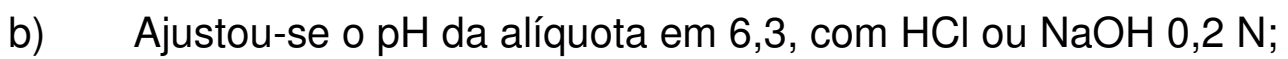

c) Transferiu-se a alíquota para um balão volumétrico de $10 \mathrm{~mL}$ e completandose o volume com água destilada;

d) Analisou-se, a amostra por espectrofotometria utilizando-se espectrofotômetro digital B 342 II (Micronal, Brasil), em comprimento de onda fixo em $547 \mathrm{~nm}$, tendo-se ajustado $\circ \mathrm{pH}$ da amostra para $\circ$ valor de 6,3 (valor ajustado em trabalhos anteriores: GUIMARÃES, 2000; PAMBOUKIAN, 2003).

Os resultados de produção de retamicina foram expressos em termos de unidades de absorbância (UA), devido à não existência de um produto comercial, purificado, do antibiótico para ser utilizado como padrão.

\subsection{Tratamento de resultados}

\subsubsection{Cálculo dos fatores de conversão, produtividades e produção específica, no cultivo com células livres e imobilizadas em batelada simples}

Os fatores de conversão, produtividades e produção específica em retamicina, nos ensaios com células livres, foram calculados a partir das seguintes equações:

$$
Y_{X / S}=\frac{X_{T m}-X_{T 0}}{S_{0}-S_{f}}
$$




$$
\begin{aligned}
& Y_{R / S}=\frac{R_{m}}{S_{0}-S_{f}{ }^{\prime}} \\
& P_{X}=\frac{X_{T m}-X_{T 0}}{t_{m}} \\
& P_{R}=\frac{R_{m}}{t_{m}{ }^{\prime}} \\
& R_{e s p}=\frac{R_{m}}{X_{T}{ }^{\prime}-X_{T 0}}
\end{aligned}
$$

Onde:

$\mathrm{Y}_{\mathrm{X} / \mathrm{S}}=$ fator de conversão substrato a células em $\mathrm{t}_{\mathrm{m}}(\mathrm{g} / \mathrm{g})$;

$\mathrm{Y}_{\mathrm{R} / \mathrm{S}}=$ fator de conversão substrato a retamicina em $\mathrm{t}_{\mathrm{m}}{ }^{\prime}(\mathrm{UA} /(\mathrm{g} / \mathrm{L}))$;

$\mathrm{P}_{\mathrm{X}}=$ produtividade em células em $\mathrm{t}_{\mathrm{m}}(\mathrm{g} / \mathrm{L} . \mathrm{h})$;

$P_{R}=$ produtividade em retamicina em $t_{m}^{\prime}(U A / h)$;

$R_{\text {esp }}=$ produção específica de retamicina no instante $t_{m}{ }^{\prime}(U A /(g / L))$;

$t_{m}=$ instante de concentração celular máxima $(h)$;

$\mathrm{t}_{\mathrm{m}}{ }^{\prime}=$ instante de produção máxima de retamicina $(\mathrm{h})$;

$\mathrm{X}_{\mathrm{T} 0}=$ concentração celular inicial total $(\mathrm{g} / \mathrm{L})$;

$\mathrm{X}_{\mathrm{Tm}}=$ concentração celular total em $\mathrm{t}_{\mathrm{m}}(\mathrm{g} / \mathrm{L})$;

$X_{T}{ }^{\prime}=$ concentração celular total em $t_{m}{ }^{\prime}(g / L)$;

$\mathrm{R}_{\mathrm{m}}=$ produção de retamicina em $\mathrm{t}_{\mathrm{m}}(\mathrm{UA})$;

$\mathrm{S}_{0}=$ concentração de glicose no instante inicial do cultivo $(\mathrm{g} / \mathrm{L})$;

$\mathrm{S}_{\mathrm{f}}=$ concentração de glicose no instante $\mathrm{t}_{\mathrm{m}}(\mathrm{g} / \mathrm{L})$;

$S_{f}{ }^{\prime}=$ concentração de glicose no instante $t_{m}{ }^{\prime}(g / L)$. 


\subsubsection{Cálculo dos fatores de conversão, produtividades e produção específica, no cultivo com células imobilizadas em bateladas repetidas}

Os fatores de conversão, produtividades e produção específica em retamicina, para cada batelada, foram calculados a partir das seguintes equações:

$$
\begin{gathered}
Y_{X / S}=\frac{X_{T f}-X_{T 0}}{S_{0}-S_{f}} \\
Y_{R / S}=\frac{R_{f}-R_{0}}{S_{0}-S_{f}} \\
P_{X}=\frac{X_{T f}-X_{T 0}}{t_{f}} \\
P_{R}=\frac{R_{f}-R_{0}}{t_{f}} \\
R_{e s p}=\frac{R_{f}-R_{0}}{X_{T f}-X_{T 0}}
\end{gathered}
$$

Onde:

$Y_{X / S}=$ fator de conversão substrato a células em $t_{f}(g / g)$;

$\mathrm{Y}_{\mathrm{R} / \mathrm{S}}=$ fator de conversão substrato a retamicina em $\mathrm{t}_{\mathrm{f}}(\mathrm{UA} /(\mathrm{g} / \mathrm{L}))$;

$P_{X}=$ produtividade em células em $t_{f}(g / L . h)$;

$P_{R}=$ produtividade em retamicina em $t_{f}(U A / h)$;

$\mathrm{R}_{\mathrm{esp}}=$ produção específica de retamicina em tf $(\mathrm{UA} /(\mathrm{g} / \mathrm{L}))$;

$t_{f}=$ instante de término da batelada $(h)$;

$\mathrm{X}_{\mathrm{T} 0}=$ concentração celular total no início da batelada $(\mathrm{g} / \mathrm{L})$

$\mathrm{X}_{\mathrm{Tf}}=$ concentração celular total no final da batelada $(\mathrm{g} / \mathrm{L})$

$\mathrm{R}_{0}=$ produção de retamicina ao início da batelada (UA);

$R_{f}=$ produção de retamicina ao final da batelada (UA);

$\mathrm{S}_{0}=$ concentração de glicose no instante inicial da batelada $(\mathrm{g} / \mathrm{L})$;

$\mathrm{S}_{\mathrm{f}}=$ concentração de glicose no instante final da batelada $(\mathrm{g} / \mathrm{L})$. 


\subsubsection{Cálculo das Velocidades Específicas para os ensaios em bateladas simples}

As velocidades específicas de crescimento celular $\left(\mu_{\mathrm{x}}\right)$, consumo de glicose $\left(\mu_{S}\right)$ e produção de retamicina $\left(\mu_{R}\right)$, para os ensaios em bateladas simples, cujos valores encontram-se no Apêndice $A$, foram determinadas a partir das equações a seguir:

$$
\begin{aligned}
& \mu_{x}=\left(1 / X_{T}\right){ }^{*}\left(d X_{T} / d t\right) \\
& \mu_{S}=\left(-1 / X_{T}\right){ }^{*}(d S / d t) \\
& \mu_{R}=\left(1 / X_{T}\right){ }^{*}(d R / d t)
\end{aligned}
$$

onde:

$\mu_{\mathrm{x}}=$ velocidade específica de crescimento $\left(\mathrm{h}^{-1}\right)$;

$\mathrm{X}_{\mathrm{T}}=$ concentração celular total $(\mathrm{g} / \mathrm{L})$;

$\mu_{S}=$ velocidade específica de consumo de substrato (glicose) (g/g.h);

$S=$ concentração de substrato (glicose) (g/L);

$\mu_{R}=$ velocidade específica de produção de retamicina (UA/(g/L).h);

$\mathrm{R}=$ produção de retamicina total (UA)

Na fase de crescimento exponencial, a velocidade específica de crescimento atinge o seu valor máximo e o crescimento pode ser representado pelas seguintes equações:

$X=X_{e} e^{\mu \max (t-t e)}$

$\ln X=\ln X_{e}+\mu_{\max }\left(t-t_{e}\right)$

onde:

$X_{e}=$ concentração celular no início da fase exponencial $(g / L)$;

$\mu_{\text {máx }}=$ velocidade específica máxima de crescimento $\left(h^{-1}\right)$;

$t_{e}=$ instante de início da fase exponencial $(h)$. 
As curvas de velocidades específicas foram calculadas utilizando-se o software Logiciel de Lissage, desenvolvido por Simões et al. (1994). Esse software calcula as velocidades específicas utilizando um método spline, que ajusta um polinômio de grau 3 ou 4 a um intervalo de dois pontos experimentais consecutivos da variável em questão (por exemplo, $\mathrm{X}$ ), incorporando um número de pontos à frente deste intervalo; além disso, o método obriga que a derivada do polinômio ajustado no intervalo anterior seja igual à derivada do polinômio ajustado no novo intervalo, no ponto de intersecção. Os polinômios obtidos são, então, derivados algebricamente em relação ao tempo, tornando possível o cálculo das velocidades específicas.

\subsubsection{Cálculo das velocidades específicas, fatores de conversão e produtividades nos ensaios contínuos}

As velocidades específicas de crescimento celular $\left(\mu_{\mathrm{x}}\right)$, consumo de glicose $\left(\mu_{\mathrm{S}}\right)$ e produção de retamicina $\left(\mu_{R}\right)$, para os ensaios contínuos ICC1 e ICC2, no estado estacionário, cujos valores encontram-se no Apêndice $A$, foram determinadas a partir das equações 3.21 a 3.23 .

$$
\begin{aligned}
& \mu_{x}=D=1 / \theta \\
& \mu_{S}=\left(D / X_{T e}\right) *\left(S_{a}-S_{e}\right) \\
& \mu_{R}=\left(D^{*} R_{e}\right) / X_{T e}
\end{aligned}
$$

Os fatores de conversão, produtividades e produção específica em retamicina, para o estado estacionário dos ensaios contínuos, foram calculados a partir das equações 3.24 a 3.28

$$
Y_{X / S}=\frac{X_{T e}}{S_{a}-S_{e}}
$$




$$
\begin{aligned}
& Y_{R / S}=\frac{R_{e}}{S_{a}-S_{e}} \\
& P_{X}=D \cdot X_{T e} \\
& P_{R}=D \cdot R_{e} \\
& R_{e s p}=\frac{R_{e}}{X_{T e}}
\end{aligned}
$$

Onde:

$\mu_{\mathrm{x}}=$ velocidade específica de crescimento no estado estacionário $\left(\mathrm{h}^{-1}\right)$;

$\mu_{\mathrm{S}}=$ velocidade específica de consumo de substrato no estado estacionário (g/g.h);

$\mu_{\mathrm{R}}=$ velocidade específica de produção de retamicina no estado estacionário (UA/(g/L).h);

$Y_{X / S}=$ fator de conversão substrato a células no estado estacionário $(\mathrm{g} / \mathrm{g})$;

$Y_{R / S}=$ fator de conversão substrato a retamicina no estado estacionário $(\mathrm{UA} /(\mathrm{g} / \mathrm{L}))$;

$\mathrm{P}_{\mathrm{X}}=$ produtividade em células no estado estacionário ( $\left.\mathrm{g} / \mathrm{L} . \mathrm{h}\right)$;

$\mathrm{P}_{\mathrm{R}}=$ produtividade em retamicina no estado estacionário (UA/h);

$R_{\text {esp }}=$ produção específica de retamicina no estado estacionário $(\mathrm{UA} /(\mathrm{g} / \mathrm{L}))$;

$\mathrm{X}_{\mathrm{Te}}=$ concentração celular total no estado estacionário $(\mathrm{g} / \mathrm{L})$

$R_{e}=$ produção de retamicina no estado estacionário (UA);

$\mathrm{S}_{\mathrm{a}}=$ concentração de glicose no meio de alimentação $(\mathrm{g} / \mathrm{L})$;

$S_{e}=$ concentração de glicose no estado estacionário $(g / L)$;

$\theta=$ tempo de residência (horas). 


\section{RESULTADOS E DISCUSSÃO}

Os resultados obtidos nos ensaios, conforme os itens 4.1 a 4.3 , são apresentados neste capítulo na forma de gráficos e os dados experimentais originais encontram-se na forma de tabelas no Apêndice A. O Quadro 4.1, a seguir, apresenta, resumidamente, as condições utilizadas em todos os ensaios realizados no presente trabalho.

Quadro 4.1 - Condições dos ensaios realizados nos biorreatores cesta e coluna de bolhas

\begin{tabular}{|c|c|c|c|c|}
\hline Ensaio & Biorreator & $\begin{array}{l}\text { Freqüência de } \\
\text { agitação (rpm) }\end{array}$ & $\begin{array}{l}\text { Aeração } \\
\left(\text { vvm }^{\star}\right)\end{array}$ & Objetivos \\
\hline SL-500 & STR & 500 & 1 & \multirow{4}{*}{$\begin{array}{l}\text { Comparação entre os } \\
\text { sistemas com células livres e } \\
\text { imobilizadas; } \\
\text { Comparação dos ensaios em } \\
\text { diferentes condições de } \\
\text { agitação e aeração com } \\
\text { células imobilizadas }\end{array}$} \\
\hline SI-500 & Cesta & 500 & 1 & \\
\hline SI-300 & Cesta & 300 & 1 & \\
\hline SI-300-80 & Cesta & 300 & 0,4 & \\
\hline SI-BR1 & Cesta & 500 & 1 & \multirow{2}{*}{$\begin{array}{l}\text { Estudo de bateladas repetidas } \\
\text { com células imobilizadas }\end{array}$} \\
\hline SI-BR2 & Cesta & 500 & 1 & \\
\hline $\mathrm{Cl}-02-30$ & Cesta & 500 & 1 & \multirow{3}{*}{$\begin{array}{l}\text { Estudo do processo contínuo } \\
\text { no com células imobilizadas } \\
\text { aplicando vazões de } \\
\text { alimentação de } \mathrm{D}=0,2 \mathrm{~h}^{-1} \text { e } \\
\qquad 0,05 \mathrm{~h}^{-1}\end{array}$} \\
\hline $\mathrm{Cl}-005-30$ & Cesta & 500 & 1 & \\
\hline Cl-005-72 & Cesta & 500 & 1 & \\
\hline IC1 & Coluna de bolhas & - & 1 & \multirow{6}{*}{$\begin{array}{l}\text { Comparação dos ensaios com } \\
\text { células livres e imobilizadas } \\
\text { em diferentes condições de } \\
\text { aeração }\end{array}$} \\
\hline IC2 & Coluna de bolhas & - & 2 & \\
\hline IC3 & Coluna de bolhas & - & 2 & \\
\hline LC1 & Coluna de bolhas & - & 1 & \\
\hline LC2 & Coluna de bolhas & - & 2 & \\
\hline LC3 & Coluna de bolhas & - & 2 & \\
\hline IC-BR & Coluna de bolhas & - & 2 & $\begin{array}{c}\text { Estudo de bateladas repetidas } \\
\text { com células imobilizadas }\end{array}$ \\
\hline IC-C1 & Coluna de bolhas & - & 2 & \multirow{2}{*}{$\begin{array}{l}\text { Estudo do processo contínuo } \\
\text { com células imobilizadas com } \\
\text { vazões de alimentação: } D= \\
0,05 \mathrm{~h}^{-1}, 0,03 \mathrm{~h}^{-1} \text { e } 0,015 \mathrm{~h}^{-1}\end{array}$} \\
\hline IC-C2 & Coluna de bolhas & - & 2 & \\
\hline
\end{tabular}




\subsection{Ensaios em biorreator tipo cesta}

\subsubsection{Ensaios em biorreator tipo cesta em bateladas simples sob diferentes condições de transferência de oxigênio}

As Figuras 4.1 a 4.4 apresentam os resultados relativos à concentração celular, consumo de glicose e produção de retamicina, obtidos nos ensaios com células de Streptomyces olindensis ICB20 imobilizadas em gel de alginato (SI-500, SI-300 e SI-300-80) e com células livres (SL-500), de acordo com a Tabela 3.1, capítulo 3 - Materiais e Métodos. O valor do $\mathrm{pH}$ manteve-se em torno de 7,0 durante a realização de todos os ensaios, apesar de não haver controle, conforme descrito no item 3.3.4.1. A presença de células livres, nos três ensaios com células imobilizadas, representou uma pequena parcela a partir de 72 horas de cultivo, na faixa de 1 a 2 g/L, provavelmente como resultado apenas do efeito de desprendimento celular do gel. Assim, optou-se por apresentar nas figuras, apenas a concentração celular total do sistema em termos de volume de reator. Anteriormente a estes ensaios também foram realizados dois ensaios preliminares, sob agitação de $500 \mathrm{rpm}$, para aprimoramento da metodologia e procedimentos experimentais.

Comparando-se os ensaios com células livres (SL-500) e imobilizadas (SI500), ambos realizados a $500 \mathrm{rpm}$ e $1 \mathrm{vvm}$ de aeração, obteve-se uma cinética de crescimento celular consideravelmente mais lenta no ensaio SI-500, assim como valores de concentração celular inferiores, cerca de $6,55 \mathrm{~g} / \mathrm{L}$ no SL-500 e 4,98 g/L no SI-500, como se observa pela Figura 4.1. Conseqüentemente observou-se um comportamento similar para a cinética de consumo de glicose, tendo esta se esgotado com 28 horas no cultivo SL-500 e apenas com cerca de 68 horas no cultivo SI-500 (Figura 4.2). Em relação aos resultados de produção (Figura 4.3), obtiveram-se valores próximos de produção de retamicina para os dois ensaios, sendo que a absorbância máxima obtida no ensaio SL-500 ficou em torno de 1,4 UA, com cerca de 28 horas de cultivo, enquanto que no ensaio SI-500 o valor máximo da absorbância foi em torno de 1,2 UA, para o tempo de 68 horas de cultivo. Estes resultados mostram claramente que as limitações difusionais de nutrientes e de oxigênio no gel ocasionaram cinéticas mais lentas nos ensaios com células 
imobilizadas, em comparação ao ensaio com células livres, efeito que poderia, a princípio, ser minimizado com uma freqüência de agitação maior que 500 rpm, porém não foi possível operar o reator com células imobilizadas porque condição ocorreu o deslocamento do gel para fora da cesta.

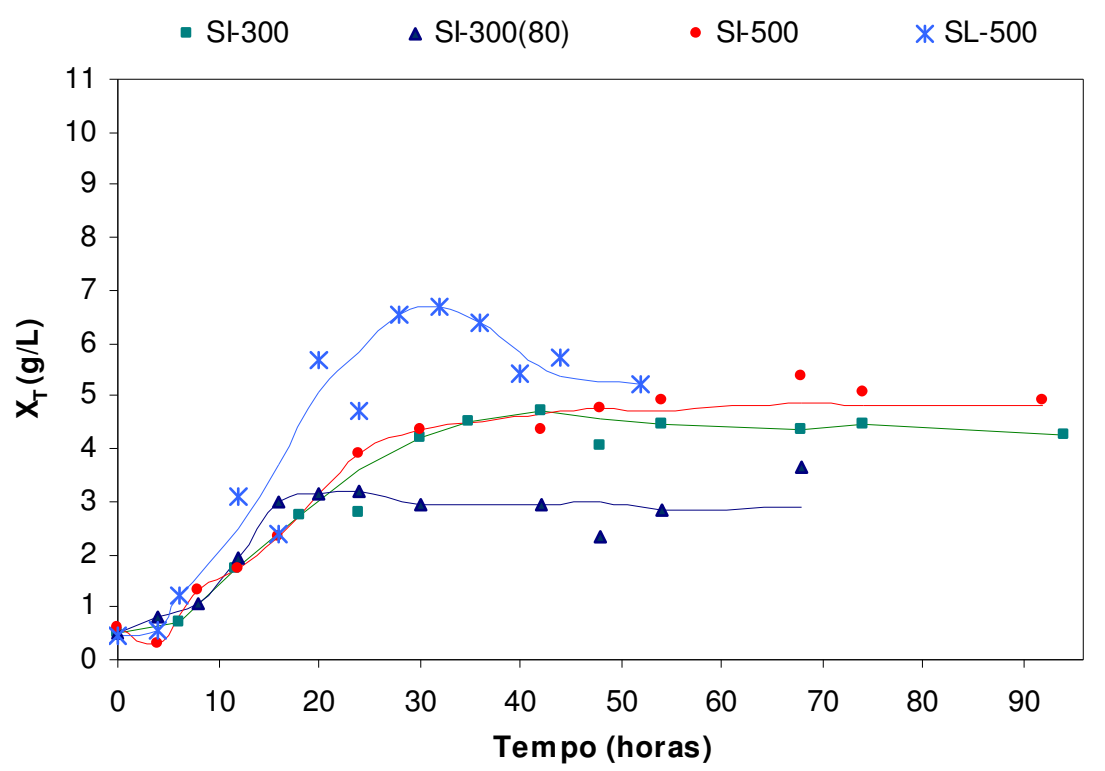

Figura 4.1 - Concentração celular total $\left(X_{T}\right)$ em função do tempo nos ensaios com células imobilizadas (SI-300, SI-300-80, SI-500) e com células livres (SL-500).

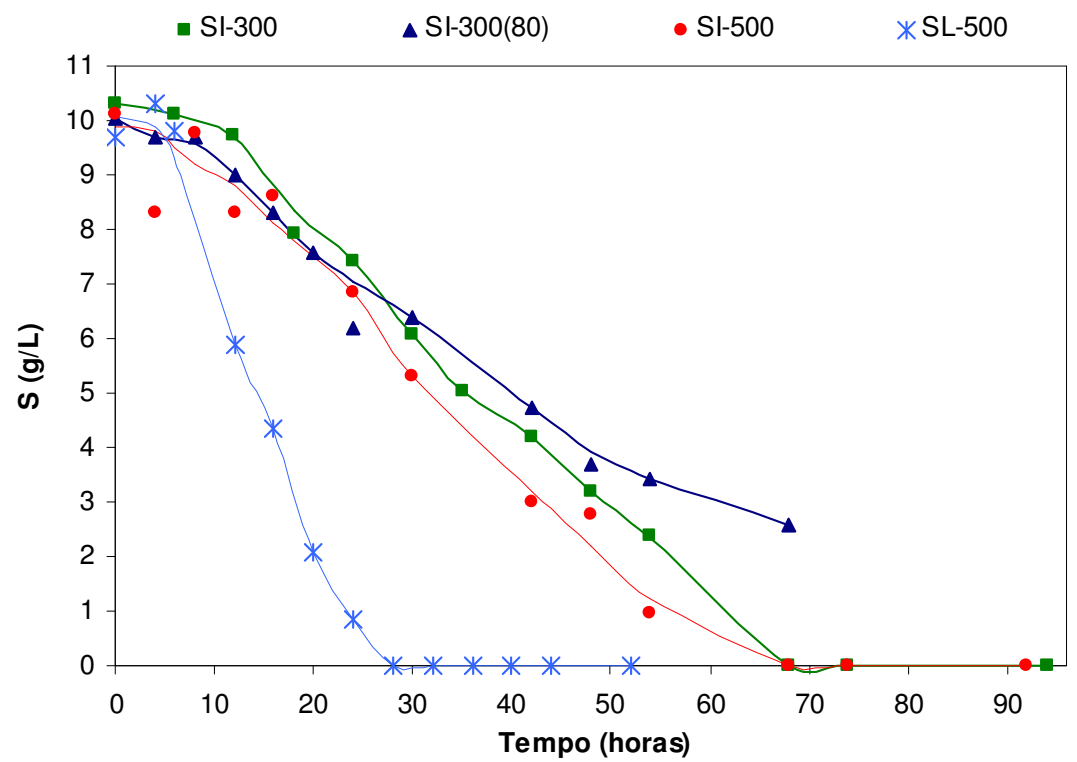

Figura 4.2 - Concentração de glicose residual (S) em função do tempo nos ensaios com células imobilizadas (SI-300, SI-30080, SI-500) e com células livres (SL-500). 


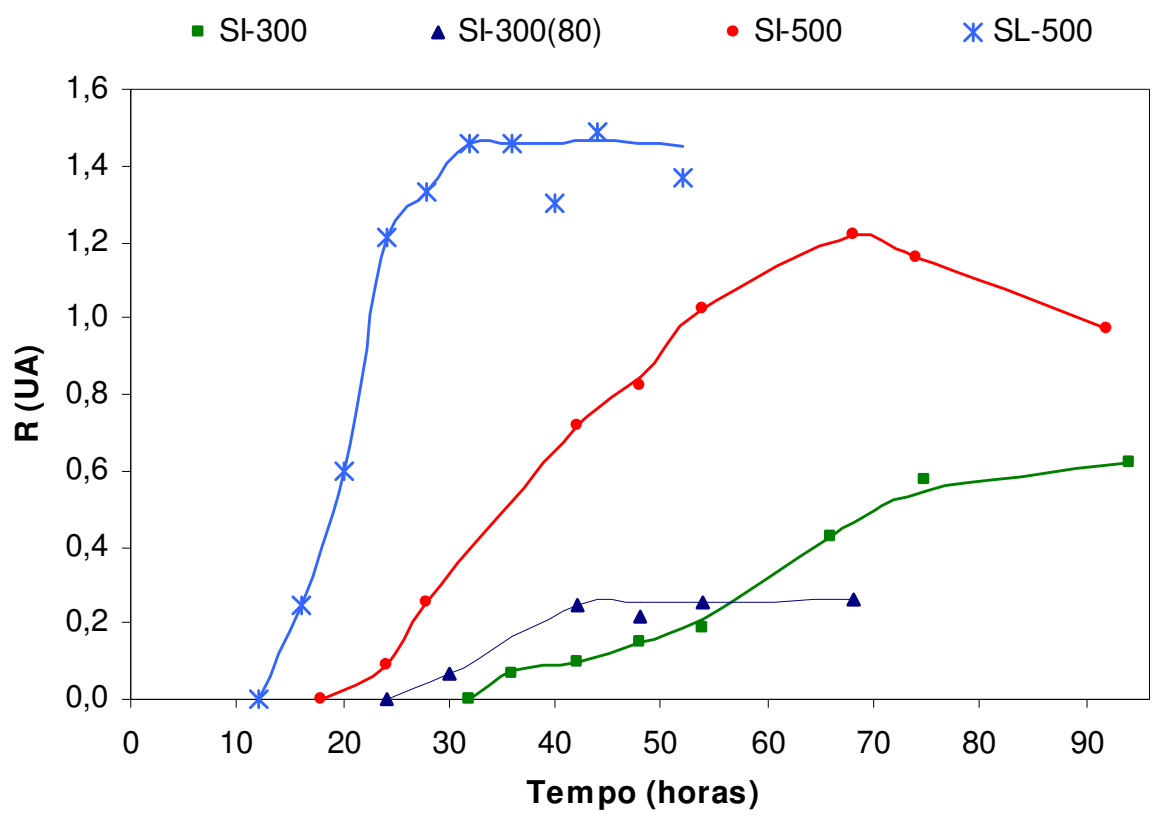

Figura 4.3 - Produção de retamicina (UA) em função do tempo nos ensaios com células imobilizadas (SI-300, SI-30080, SI-500) e com células livres (SL-500).

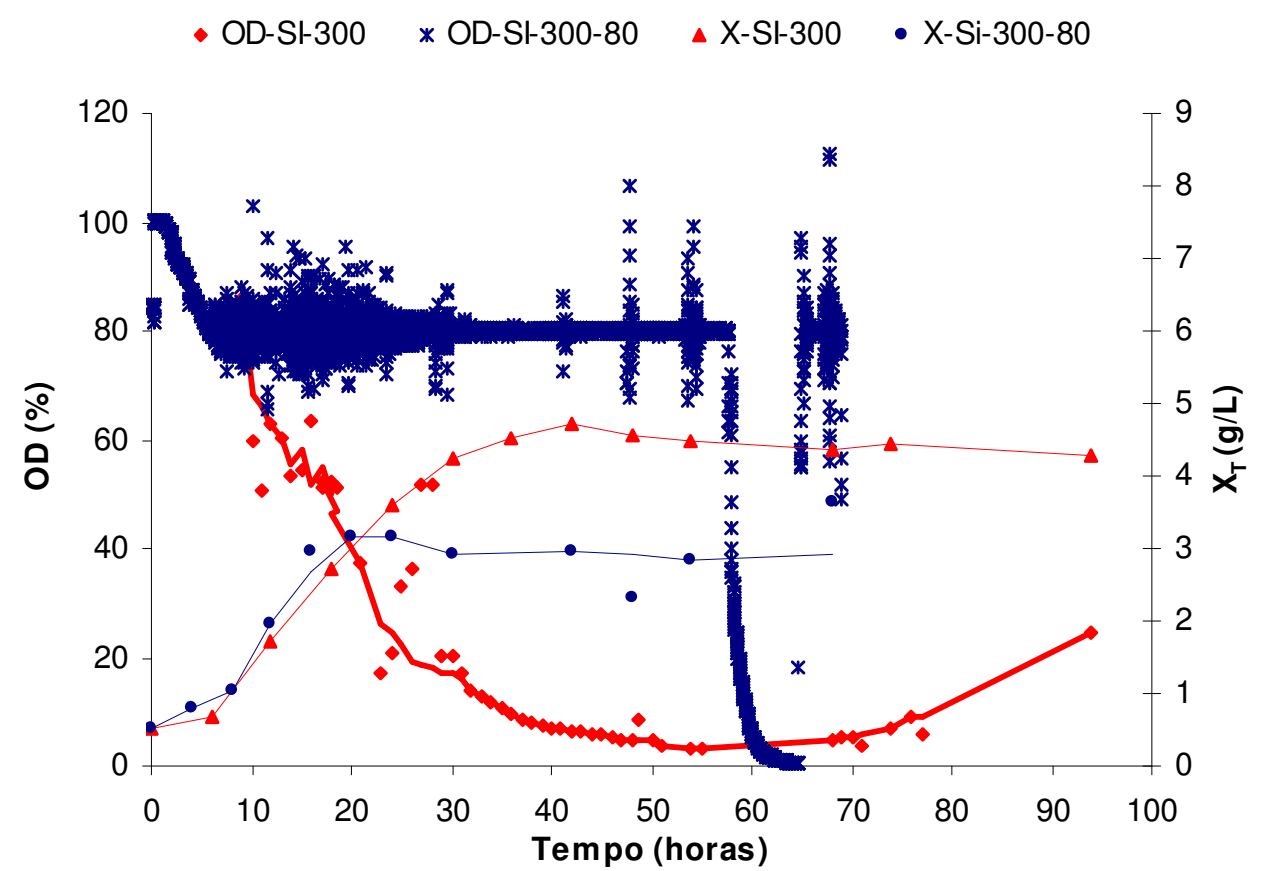

Figura 4.4 - Perfil de Oxigênio dissolvido (OD) e Concentração celular total (X) nos ensaios com células imobilizadas, sob diferentes condições de aeração (SI-300, SI-300-80). 
Nesta primeira comparação o sistema com células imobilizadas de $S$. olindensis ICB20, em biorreator tipo cesta, pode não ter se apresentado mais vantajoso em relação ao sistema com células livres, porém considerando-se que uma das vantagens da utilização de biorreatores com células imobilizadas é a possibilidade de reutilização das células, este tipo de sistema pode ser considerado potencialmente viável em processos de longa duração, conforme será mostrado no item 4.2. Neste sentido, o trabalho de Azevedo (2005), com S. olindensis ICB20 imobilizadas em alginato, em sistema de bateladas repetidas em frascos erlenmeyer, mostrou que foram obtidas cinéticas mais rápidas a partir da segunda batelada, e conseqüentemente foram obtidos melhores valores de produtividades quando comparados a ensaios com apenas uma batelada.

A figura 4.5 ilustra o experimento SI-500 no início do ensaio e após decorridas 72 horas de cultivo. A mudança de coloração do meio para os diferentes tempos indica a produção da retamicina, a qual possui coloração roxa para valores de $\mathrm{pH}$ em torno de 7,0, valor este que foi observado durante todo o cultivo, não sendo necessário portanto o seu controle com adição de ácido ou base.
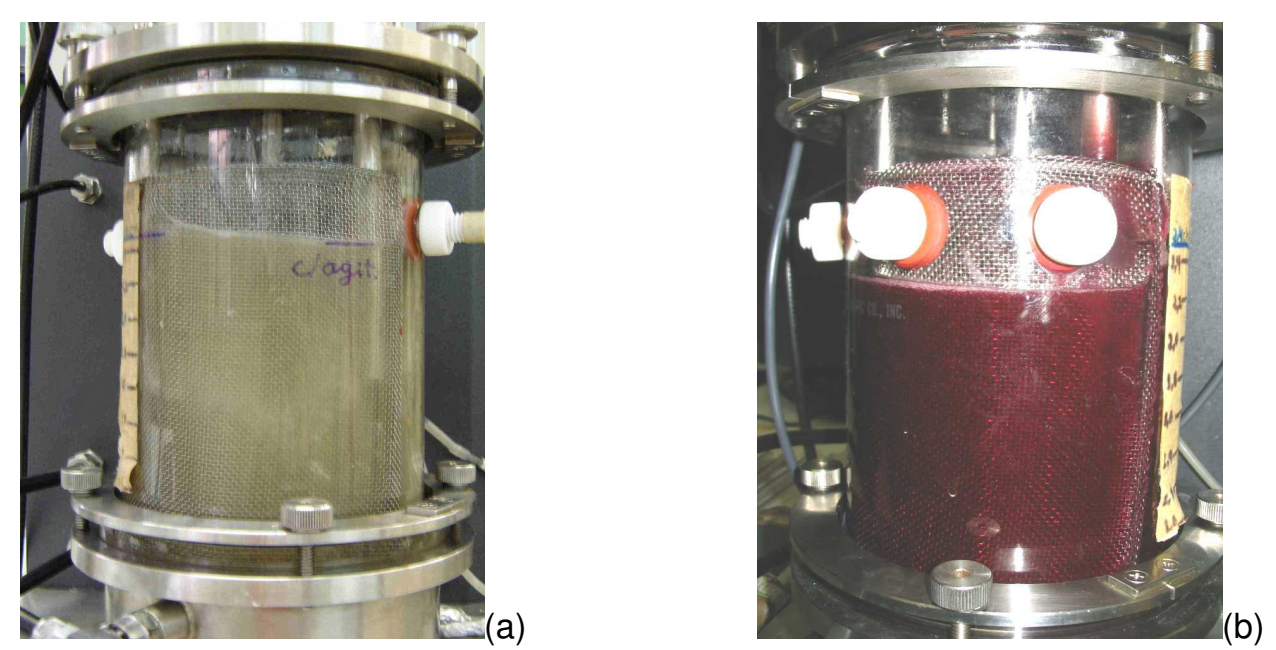

Figura 4.5 - Ensaio SI-500 no instante inicial (a) e após 72 horas (b) de cultivo.

Comparando-se os ensaios realizados com células imobilizadas em diferentes freqüências de agitação (SI-300 e SI-500), pode-se observar que embora o crescimento celular e o consumo de glicose tenham apresentado um comportamento semelhante, a produção de retamicina foi afetada no ensaio SI-300, atingindo 
apenas o valor de 0,6 UA em cerca de 94 horas de cultivo, enquanto que a produção no ensaio SI-500 foi cerca de duas vezes superior, 1,2 UA em 68 horas de cultivo. Possivelmente a baixa produção de retamicina no ensaio SI-300 possa ser explicada por uma limitação de oxigênio no sistema (Figura 4.4), já que a concentração de oxigênio dissolvido encontrava-se em níveis inferiores a $20 \%$ no meio de cultivo a partir de aproximadamente 24 horas, concentração esta que deve ser menor ainda no interior do gel, de acordo com perfil de oxigênio em esferas de gel apresentados por Ogbonna (1991). A baixa concentração de oxigênio neste ensaio foi causada pela aplicação da menor freqüência de agitação (300 rpm), tendo-se em vista que no ensaio a 500 rpm a concentração de oxigênio dissolvido encontrava-se em níveis acima de $90 \%$ no meio de cultivo, durante o decorrer de todo ensaio (valor observado nos ensaios preliminares, pois, no ensaio SI-500, em particular, houve problema com o eletrodo de oxigênio dissolvido).

Estes resultados são coerentes com os obtidos por Martins (2000), a qual observou em seus ensaios com células livres de Streptomyces olindensis, sob baixas concentrações de oxigênio dissolvido na fase de crescimento celular, que a produção da retamicina foi desfavorecida, pois, possivelmente a baixa disponibilidade de oxigênio prejudica a síntese de alguns precursores do antibiótico.

No trabalho de Carvalho (2004), o estudo de diferentes níveis de agitação e aeração para obtenção de xilitol por células imobilizadas em alginato, em biorreator tipo cesta, mostrou-se que a elevação da freqüência de agitação de 300 para 500 rpm causou decréscimos no rendimento obtido ao final da fermentação, isto porque a maior taxa de transferência de oxigênio favoreceu o crescimento celular em detrimento da produção do xilitol. Diferentemente, no presente trabalho, maiores taxas de transferência de oxigênio no ensaio SI-500, favoreceram tanto 0 crescimento celular quanto a produção da retamicina.

Tavares (1994), por sua vez, não observou influência significativa na produção de etanol em biorreator tipo cesta por leveduras imobilizadas em gel de pectina, visto que foram obtidos resultados similares de produtividade na faixa de 300 a 700 rpm, provavelmente por se tratar de um processo anaeróbio.

O ensaio SI-300-80 foi realizado com aeração de 0,4 vvm (conforme Tabela 3.1 do capítulo 3 - Materiais e Métodos) e foi adicionado oxigênio à composição de gases na entrada do biorreator, com o intuito de controlar a concentração de oxigênio dissolvido no meio, em torno de $80 \%$ da saturação. Este procedimento teve 
o objetivo de tentar observar se esta condição levaria a um resultado melhor que o obtido no ensaio conduzido a $300 \mathrm{rpm}$ (SI-300), no qual se chegou a níveis baixos de concentração de oxigênio dissolvido (menor que 20\%) no meio, durante o período de 24 horas até cerca de 84 horas de cultivo (Figura 4.4), o que poderia ter prejudicado a produção da retamicina, conforme comentado anteriormente. Porém, como se optou por utilizar neste ensaio a vazão de aeração de 0,4 vvm com o objetivo de realizar um balanço gasoso para determinar a velocidade de respiração celular, esta condição parece ter afetado negativamente a difusão de nutrientes no gel e, conseqüentemente, o crescimento celular a partir de 24 horas de cultivo, conforme se observou nas figuras 4.1 e 4.4. Observou-se também que no ensaio SI300-80 não houve o consumo total de glicose até cerca de 72 horas de cultivo, restando cerca de $2 \mathrm{~g} / \mathrm{L}$ (Figura 4.2), e a produção de retamicina se estabilizou em torno de $0,25 \cup A$, desde cerca de 40 horas de cultivo.

Os problemas ocorridos no ensaio SI-300-80 podem ser possivelmente entendidos porque neste tipo de sistema formava-se um leito empacotado do gel, no interior da cesta, o que dificultava a difusão de nutrientes e oxigênio às células. Esta difusão poderia ser favorecida por uma maior distribuição de bolhas no leito empacotado, o que no entanto não ocorreu devido à baixa vazão utilizada. Portanto, o fato de se ter controlado o oxigênio dissolvido em $80 \%$ não causou o efeito esperado favorável à produção de retamicina, de forma a melhorar os resultados obtidos no ensaio SI-300, sem controle de oxigênio dissolvido.

A figura 4.6 apresenta as curvas de $\ln \left(\mathrm{X}_{\mathrm{T}}\right)$ em função do tempo, a partir das quais foram obtidos os valores de velocidade específica máxima de crescimento $\left(\mu_{\max }\right)$ para os ensaios no reator cesta, conforme a equação 3.20 , os quais são apresentados na tabela 4.1 . 

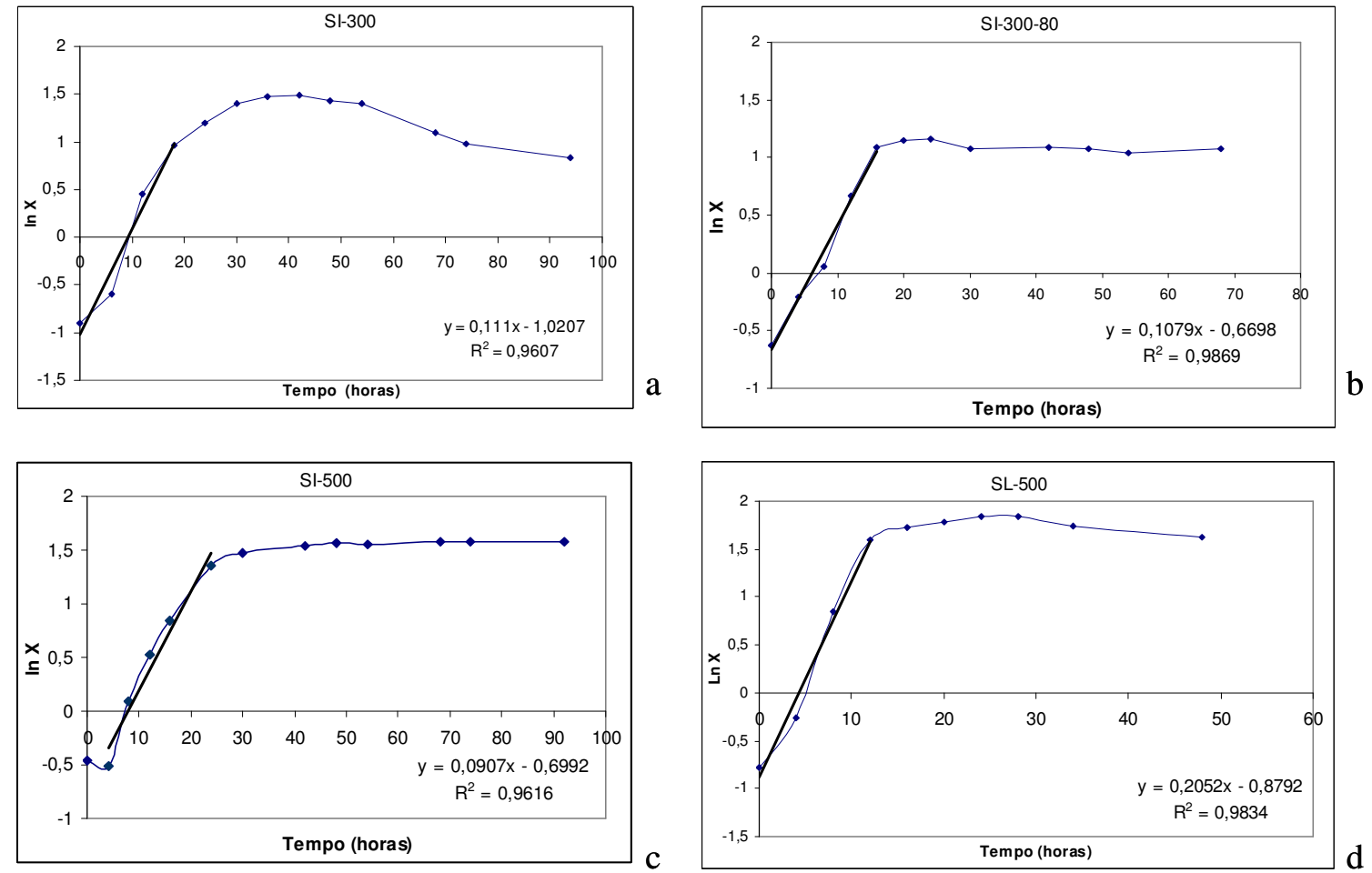

Figura 4.6 - In (XT) em função do tempo para os ensaios SI-300 (a), SI-300-80 (b), SI-500 (C) e SL-500 (d).

Verificou-se portanto que os valores de $\mu_{\max }$ observados para a condição de 500 rpm tantos com células livres quanto com células imobilizadas foram similares, em torno de $0,2 \mathrm{~h}^{-1}$, enquanto que para os ensaios com menor agitação (300 rpm) foi observado um $\mu_{\max }$ de $0,11 \mathrm{~h}^{-1}$ para o ensaio SI-300 e $0,14 \mathrm{~h}^{-1}$ no ensaio SI-300-80. O fato de se obterem valores similares de $\mu_{\max }$ de crescimento celular para os ensaios SI-500 e SL-500, à primeira vista, poderia parecer contraditório com a discussão apresentada anteriormente, na qual foi enfatizada a ocorrência de uma cinética de crescimento mais lenta no ensaio SI-500. Porém, o fato é que ambas as fases exponenciais foram observadas entre 2 e 16 horas de cultivo para o ensaio SI500 e entre 0 e 12 horas no ensaio SL-500, períodos estes em que não se verificavam as limitações difusionais de nutrientes e oxigênio mencionadas anteriormente para o ensaio SI-500, devido ao fato de não se ter atingido neste período a máxima concentração celular no interior do gel.

Os perfis de velocidades específicas de crescimento celular, consumo de substrato e produção de retamicina, obtidos através do programa Logiciel de Lissage (SIMÕES, 1994), conforme item 3.6.3 - Materiais e Métodos, podem ser analisados a partir da figura 4.7, a seguir. Podem ser observadas pequenas diferenças entre os valores de 
velocidade específica máxima de crescimento calculado pelo Lissage e pelo gráfico de In X, em função dos ajustes de polinômio empregados para o ajuste das curvas de crescimento celular no Lissage, sendo o valor correto de $\mu_{\max }$ obtido a partir das figuras apresentadas anteriormente (Figura 4.6).

A partir da figura 4.7, constata-se que os ensaios com células imobilizadas apresentaram uma significativa defasagem entre as curvas de velocidade específica de crescimento celular $\left(\mu_{\mathrm{X}}\right)$ e de produção de retamicina $\left(\mu_{\mathrm{P}}\right)$, comportamento típico da produção de metabólitos secundários, ou seja, um padrão bifásico, caracterizado pela nítida distinção entre a fase de crescimento (trofofase) e fase de produção (idiofase). $O$ ensaio com células livres também apresentou uma defasagem entre as curvas de $\mu_{X}$ e $\mu_{P}$, porém, apresentaram uma pequena intersecção, ou seja, a velocidade de produção começou a aumentar quando a velocidade de crescimento ainda estava decaindo, sendo estes perfis observados em cultivos de células livres de $S$. olindensis ICB20 no trabalho de Pamboukian (2003), o qual obteve uma correlação negativa entre $\mu_{P}$ e $\mu_{x}$.
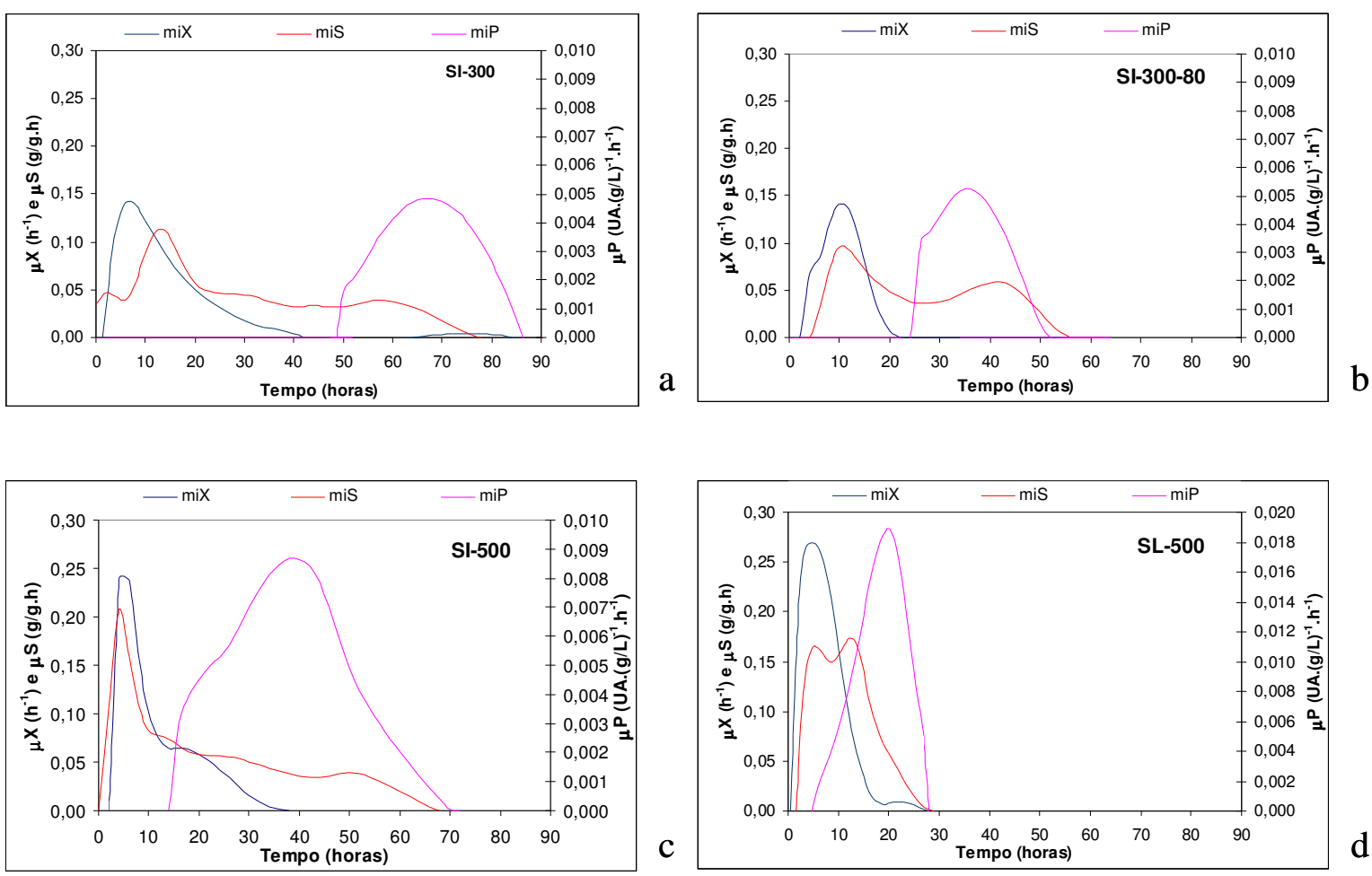

Figura 4.7 - Velocidades específicas de crescimento celular $\left(\mu_{\mathrm{x}}\right)$, consumo de substrato $\left(\mu_{\mathrm{S}}\right)$ e produção de retamicina $\left(\mu_{\mathrm{P}}\right)$ em função do tempo para os ensaios SI-300 (a),SI-300-80 (b), SI-500 (c) e SL-500 (d). 
Em relação aos perfis de velocidade específica de consumo da glicose, observou-se que estes aumentaram com o aumento da velocidade específica de crescimento celular, porém no ensaio SL-500 a velocidade de consumo decaiu rapidamente, enquanto que nos ensaios com células imobilizadas houve um decréscimo mais lento, tendo em vista as limitações difusionais, que se apresentaram mais significativamente após o crescimento celular no gel.

A tabela 4.1, a seguir, apresenta os parâmetros calculados a partir dos resultados obtidos nos cultivos que compõem esta etapa do trabalho. A definição e o cálculo dos parâmetros da tabela 4.1 encontram-se descritos no item 3.6.1 (Capítulo 3 - Materiais e Métodos).

Tabela 4.1 - Resumo dos Resultados obtidos nos ensaios SL-500, SI-500, SI-300 e SI-300-80

\begin{tabular}{|c|c|c|c|c|}
\hline & \multicolumn{4}{|c|}{ Ensaio } \\
\hline & SL-500 & SI-500 & SI-300 & SI-300(80) \\
\hline $\mathrm{X}_{\mathrm{T} 0}$ & 0,47 & 0,42 & 0,40 & 0,30 \\
\hline $\mathrm{X}_{\mathrm{Tm}}(\mathrm{g} / \mathrm{L})$ & 6,55 & 4,36 & 4,51 & 2,98 \\
\hline $\mathrm{X}_{\mathrm{T}}^{\prime}$ & 6,67 & 5,38 & 4,90 & 2,96 \\
\hline$t_{m}$ & 28 & 30 & 35 & 16 \\
\hline $\mathrm{t}_{\mathrm{m}}^{\prime}$ & 32 & 68 & 94 & 42 \\
\hline$S_{0}(g / L)$ & 9,7 & 9,2 & 10,3 & 10,0 \\
\hline$S_{f}$ & 0 & 2,2 & 4,2 & 4,7 \\
\hline$S_{f}^{\prime}$ & 0 & 0 & 0 & 4,7 \\
\hline Fase Exponencial (h) & 0 a 20 & 0 a 16 & 2 a 16 & 0 a 12 \\
\hline$\mu_{\max }\left(\mathrm{h}^{-1}\right)$ & 0,20 & 0,09 & 0,11 & 0,11 \\
\hline $\mathrm{R}_{\mathrm{m}}(\mathrm{UA})$ & 1,30 & 1,20 & 0,63 & 0,26 \\
\hline$Y_{X / S}(g / g)$ & 0,60 & 0,61 & 0,71 & 0,53 \\
\hline $\mathrm{Y}_{\mathrm{R} / \mathrm{S}}(\mathrm{UA} /(\mathrm{g} / \mathrm{L}))$ & 0,13 & 0,13 & 0,06 & 0,03 \\
\hline$P_{X}(g / L . h)$ & 0,22 & 0,16 & 0,12 & 0,17 \\
\hline$P_{R}(U A / h)$ & 0,046 & 0,018 & 0,007 & 0,013 \\
\hline $\mathrm{R}_{\mathrm{esp}}(\mathrm{UA} /(\mathrm{g} / \mathrm{L}))$ & 0,206 & 0,245 & 0,142 & 0,087 \\
\hline
\end{tabular}

${ }^{*} t_{m}$ : instante de máxima concentração celular

${ }^{* *} t_{m}$ : instante de máxima absorbância 
A partir dos valores da tabela 4.1 pode-se observar que nos ensaios com freqüência de agitação de $500 \mathrm{rpm}$ (SL-500 e SI-500), os valores de fatores de conversão de substrato à célula $\left(\mathrm{Y}_{\mathrm{X} / \mathrm{S}}\right)$ de substrato a retamicina $\left(\mathrm{Y}_{\mathrm{R} / \mathrm{S}}\right)$ foram similares, em torno de $0,6 \mathrm{~g} / \mathrm{g}$ e $0,13 \mathrm{UA} /(\mathrm{g} / \mathrm{L})$, respectivamente. Porém, observou-se uma diferença significativa nos valores produtividades em células e em produto ( $P_{x} \mathrm{e}$ $P_{R}$ ), quando se comparam os ensaios com células livres e os ensaios com células imobilizadas, devido às cinéticas consideravelmente mais lentas desses últimos.

Contudo, a produção específica em retamicina $\left(R_{\text {esp }}\right)$ no ensaio $\mathrm{SI}-500$ apresentou um valor ligeiramente superior $(0,245 \mathrm{UA} /(\mathrm{g} / \mathrm{L}))$ em relação ao ensaio $\mathrm{SL}-500(0,206 \mathrm{UA} /(\mathrm{g} / \mathrm{L}))$, indicando uma mudança no metabolismo das células imposto pela condição de estresse causada pela imobilização, favorecendo desta forma, a síntese dos metabólitos secundários (MAHMOUD; REHM, 1987).

Em seu trabalho, Lavarda (2003) observou que o sistema com células de Streptomyces clavuligerus imobilizadas apresentou uma maior conversão de substrato a células (cerca de 1,4 vezes maior) em relação ao cultivo com células livres. Diferentemente de Lavarda (2003), os valores obtidos no presente trabalho mostram que o fator de conversão de substrato a células $(\mathrm{YX} / \mathrm{s})$ apresentou-se similar, indicando que a limitação da difusão de nutrientes no gel não causou influência neste parâmetro.

Ainda com relação aos resultados apresentados na Tabela 4.1, observou-se que dentre ensaios com as células imobilizadas, o ensaio SI-500 foi o que apresentou os melhores resultados de produção de retamicina, em termos do fator de conversão $\left(Y_{p / s}\right)$, de produtividade $\left(P_{R}\right)$ e de produção específica $\left(R_{e s p}\right)$, sendo então esta condição a escolhida para a continuidade do trabalho, nos ensaios em bateladas repetidas e contínuos no biorreator tipo cesta (itens 4.1.2 e 4.1.3).

\subsubsection{Ensaios em bateladas repetidas no biorreator tipo cesta com células imobilizadas.}

Os resultados dos dois ensaios em bateladas repetidas realizados conforme descrito no item 3.3.4.3, são apresentados nas figuras 4.9 (SI-BR1) e 4.10 (SI-BR2). Encontram-se representados os perfis da concentração celular livre no meio $\left(\mathrm{X}_{\mathrm{M}, \mathrm{R}}\right)$, glicose $(\mathrm{S})$ e produção de retamicina $(\mathrm{R})$ em função do tempo. A concentração de 
células imobilizadas foi determinada apenas no início e no final de cada batelada, devido à dificuldade da manutenção de condições de assepsia ao longo dos cultivos nos instantes de retirada de amostra do gel, já que era necessária a abertura do biorreator para a retirada da amostra.

A quantidade de bateladas nos dois ensaios limitou-se a apenas três porque houve um problema operacional ao final da terceira batelada: as células livres aderiram na superfície da cesta, sobre a qual cresceram significativamente, formando uma camada espessa de células entre a cesta e a parede do biorreator (conforme figura 4.8 (a) e (b)), de forma que não havia homogeneidade no meio de cultivo, já que este não circulava na parte externa da cesta. Mesmo após a retirada de todo o meio, ao final da terceira batelada, as células continuaram "aderidas" na cesta, inviabilizando a continuidade de bateladas subseqüentes. Realizou-se ainda, um ensaio posterior (dados não mostrados) no qual tentou-se minimizar o problema de acúmulo de células através da realização de uma lavagem do biorreator com solução salina $(0,9 \%)$ ao final de cada batelada, porém a lavagem não teve o efeito esperado, pois se observou novamente a adesão das células na cesta, além de terse obtido uma cinética mais lenta em comparação ao ensaio SI-BR1.

O tempo de cada batelada teve duração de acordo com a observação da estabilização da produção da retamicina, pois conforme observado nos ensaios em bateladas repetidas em incubador rotativo para $S$. olindensis imobilizadas em alginato (AZEVEDO, 2005), após o esgotamento da fonte de carbono ainda se observava um incremento no valor da produção.

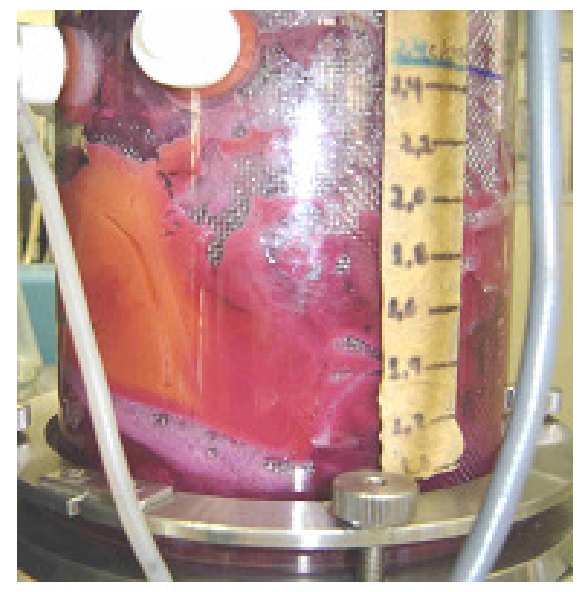

a

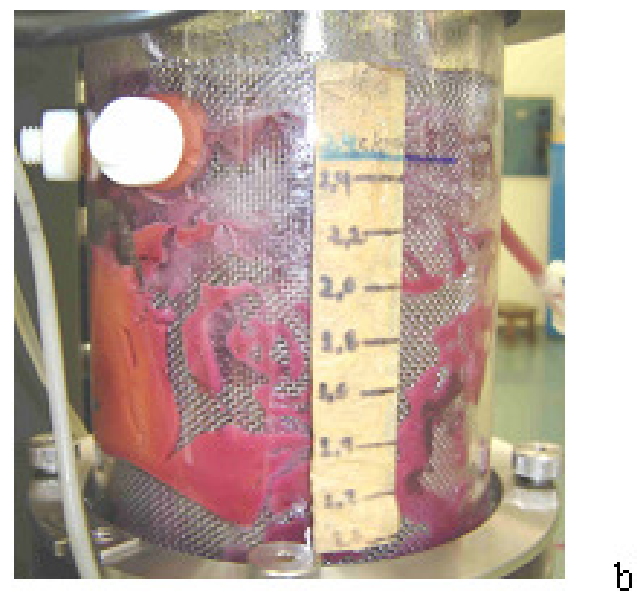

Figura 4.8 - Ensaio SI-BR1 antes (a) e depois (b) da retirada do meio, ao final da terceira batelada. 
Pela figura 4.9, referente ao ensaio SI-BR1, pode-se observar que a cinética obtida na primeira batelada foi mais lenta em comparação com o ensaio SI-500 (Fig. 4.1 a 4.3). No ensaio SI-500 o final da fonte de carbono deu-se com cerca de 68 horas de cultivo, enquanto que nesta primeira batelada o final da fonte de carbono foi observado com cerca de 90 horas de cultivo. Uma possível explicação para este resultado pode ter sido uma menor concentração celular total no início do ensaio SIBR1 (cerca de 0,2 g/L - Tabela 4.2), em comparação aos ensaios realizados anteriormente (cerca de 0,4 g/L, conforme Tabela 4.1). Na tentativa de se contornar a influência deste efeito foi, então, realizado o ensaio SI-BR2, no qual dobrou-se o volume de inóculo utilizado na etapa de imobilização (item 5.3.3), garantindo assim uma maior concentração celular imobilizada no início do ensaio.

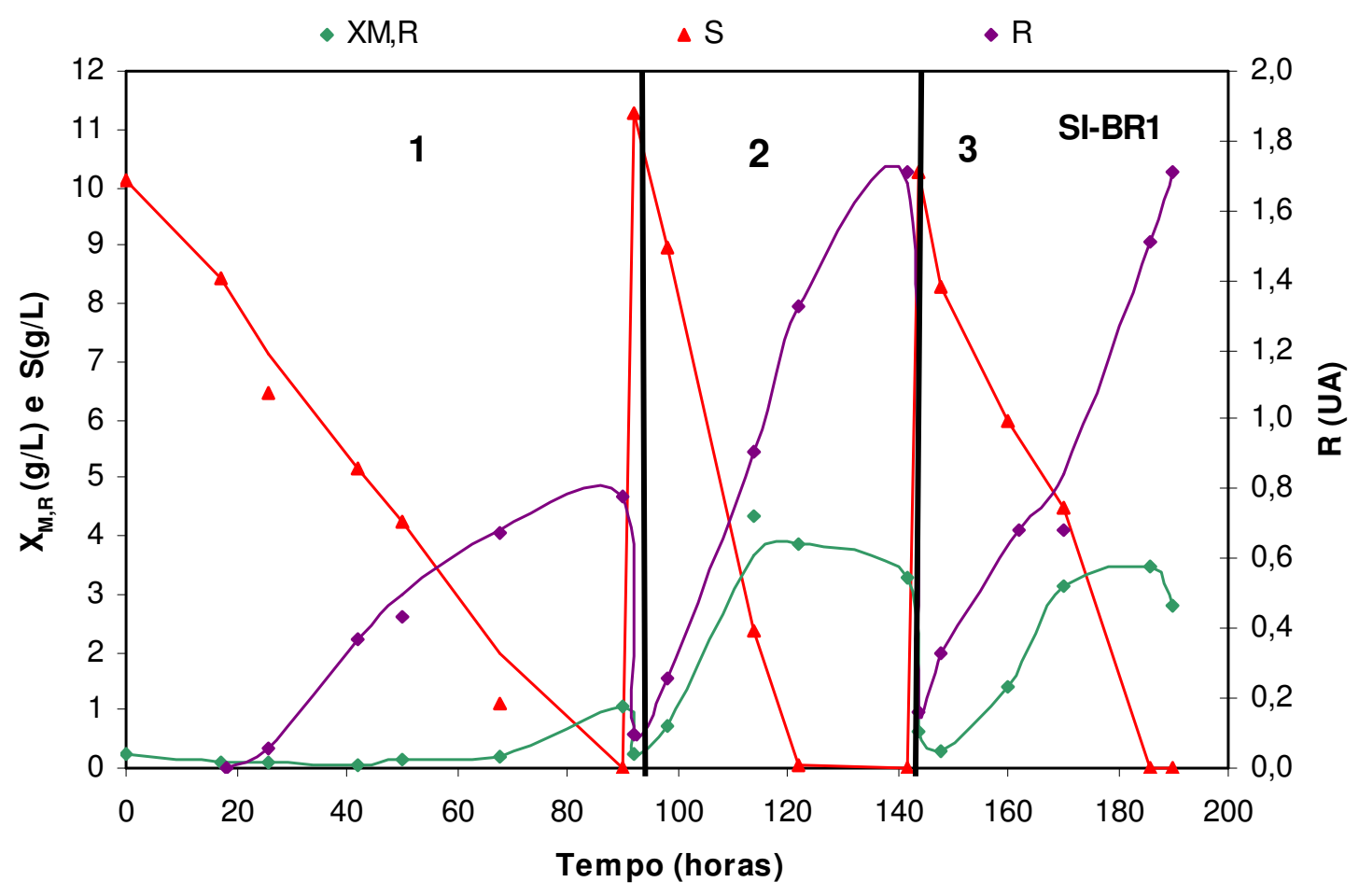

Figura 4.9 - Concentração celular livre no meio de cultivo $\left(X_{M, R}\right)$, concentração de glicose residual $(S)$ e produção de retamicina $(R)$ em função do tempo no ensaio SI-BR1. 


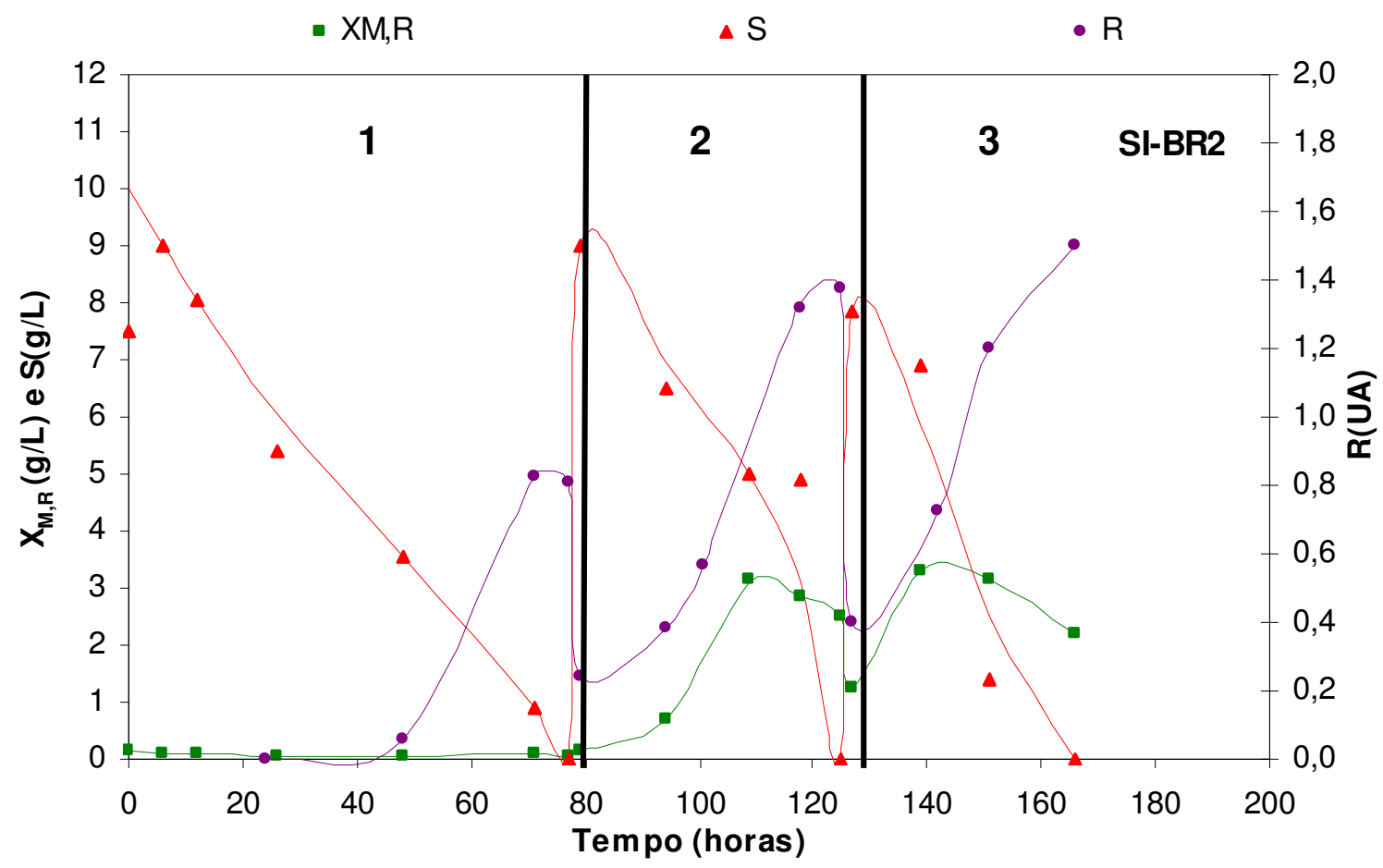

Figura 4.10 - Concentração celular livre $\left(X_{\text {meio }}\right)$, concentração de glicose residual $(S)$ e produção de retamicina $(R)$ em função do tempo no ensaio SI-BR2.

Parece que realmente o fato da concentração celular inicial $\left(\mathrm{X}_{T 0}\right)$ do ensaio SI-BR2 ter sido maior (cerca de 0,6 g/L, conforme a Tabela 4.2) levou a uma cinética mais rápida da primeira batelada, em comparação ao ensaio SI-BR1, assimilando-se à cinética obtida no ensaio SI-500, porém o valor máximo da produção de retamicina, cerca de 0,8 $\mathrm{UA}$, foi aproximadamente o mesmo da batelada 1 do ensaio SI-BR1, valor este inferior ao obtido no ensaio SI-500 (1,2 UA).

Pode-se ainda observar, pelas figuras 4.9 e 4.10, que a produção de retamicina atingiu valores superiores nas bateladas 2 e 3 de ambos os ensaios (SIBR1 e SI-BR2), em relação à batelada 1, sendo que o maior valor obtido foi de aproximadamente 1,7 UA no ensaio SI-BR1. Este valor é consideravelmente maior, quando comparado com o valor da primeira batelada $(0,8 \mathrm{UA})$ e até mesmo superior ao obtido no ensaio com células livres (SL-500 - cerca de 1,4 UA). Pode-se concluir, então, que este acréscimo no valor da produção da retamicina nos ensaios em bateladas repetidas deve-se tanto à produção pelas células imobilizadas, quanto pelas células livres, tendo em vista que houve um significativo aumento da produção de retamicina nas bateladas 2 e 3 de ambos os ensaios, a partir do momento que as curvas de concentração celular livre $\left(\mathrm{X}_{\mathrm{M}, \mathrm{R}}\right)$ estabilizaram-se. Este comportamento 
não foi observado no trabalho de Azevedo (2005), em frascos erlenmeyer, o qual observou produção de retamicina apenas pelas células imobilizadas, atingindo uma produção um pouco inferior, de cerca de 0,65 UA, devido às condições em erlenmeyer não favorecerem a produção por células livres devido aos baixos níveis de transferência de oxigênio.

A tabela 4.2 apresenta os parâmetros calculados a partir dos resultados obtidos nos cultivos em bateladas repetidas (SI-BR1 e SI-BR2) nos biorreator cesta. A definição e os cálculos destes parâmetros foram descritos no item 3.6.2 (Capítulo 3 - Materiais e Métodos).

Tabela 4.2 - Resumo dos resultados obtidos nos ensaios SI-BR1 e SI-BR2

\begin{tabular}{|c|c|c|c|c|c|c|c|}
\hline Ensaio & \multicolumn{3}{|c|}{ № da Batelada } & Ensaio & \multicolumn{3}{|c|}{ № da Batelada } \\
\hline SI-BR1 & 1 & 2 & 3 & SI-BR2 & 1 & 2 & 3 \\
\hline If (II) & 90 & 52 & 40 & (f (III) & 77 & 48 & 41 \\
\hline $\mathrm{S}_{0}(\mathrm{~g} / \mathrm{L})$ & 10,10 & 11,26 & 10,20 & $\mathrm{~S}_{0}(\mathrm{~g} / \mathrm{L})$ & 9,00 & 9,00 & 8,00 \\
\hline $\mathrm{X}_{\mathrm{TO}}(\mathrm{g} / \mathrm{L})$ & 0,22 & 1,82 & 3,74 & $\mathrm{X}_{\mathrm{TO}}(\mathrm{g} / \mathrm{L})$ & 0,68 & 2,77 & 5,05 \\
\hline $\mathrm{X}_{\mathrm{Tf}}(\mathrm{g} / \mathrm{L})$ & 2,62 & 6,42 & 5,52 & $\mathrm{X}_{\mathrm{tf}}(\mathrm{g} / \mathrm{L})$ & 2,65 & 6,32 & 7,43 \\
\hline $\mathrm{R}_{0}(\mathrm{UA})$ & 0 & 0,10 & 0,16 & $\mathrm{R}_{\mathrm{f}}($ & 0 & 0,24 & 0,40 \\
\hline $\mathrm{R}_{\mathrm{f}}(\mathrm{UA})$ & 0,78 & 1 & 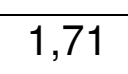 & $\mathrm{R}_{\mathrm{f}}(\mathrm{UA})$ & 0 & 1,38 & 1,50 \\
\hline$P_{X}(g / L . h)$ & 27 & 088 & 037 & $r \times(g / L . I I)$ & 026 & 0,074 & 0,058 \\
\hline $\mathrm{P}_{\mathrm{R}}(\mathrm{UA} / \mathrm{h})$ & 0,009 & 0,031 & 0,032 & $\mathrm{P}_{\mathrm{R}}(\mathrm{UA} / \mathrm{h})$ & 0,011 & 0,024 & 0,027 \\
\hline $\mathrm{Y}_{\mathrm{R} / \mathrm{S}}(\mathrm{UA} /(\mathrm{g} / \mathrm{L}))$ & 0,077 & 0,145 & 0,152 & $\mathrm{Y}_{\mathrm{R} / \mathrm{S}}(\mathrm{UA} /(\mathrm{g} / \mathrm{L}))$ & 0,090 & 0,127 & 0,138 \\
\hline$Y_{X / S}(g / g)$ & 0,24 & 0,41 & 0,18 & $Y_{X / S}(g / g)$ & 0,22 & 0,39 & 0,30 \\
\hline$\beta_{\text {esp }}(\mathrm{UA} /(\mathrm{g} / \mathrm{L}))$ & 0,325 & 0,354 & 0,870 & $\mathrm{R}_{\text {esp }}(\mathrm{UA} /(\mathrm{g} / \mathrm{L}))$ & 0,411 & 0,321 & 0,462 \\
\hline
\end{tabular}

Comparando-se os resultados dos ensaios em bateladas repetidas em biorreator, apresentados na tabela 4.2, pode-se observar que: pelo fato do ensaio SI-BR2 ter iniciado com uma concentração celular $\left(\mathrm{X}_{\mathrm{TO}}\right)$ maior que o ensaio SI-BR1, os valores de concentração celular total final $\left(X_{T_{f}}\right)$ foram consideravelmente superiores, tendo-se atingido cerca de 7,43 $\mathrm{g} / \mathrm{L}$ ao final da terceira batelada do SIBR2. No entanto, estes valores superiores de concentração celular não garantiram um incremento no valor da produção da retamicina, tendo-se observado valores ligeiramente superiores de absorbância para o ensaio SI-BR1 (cerca de 1,7 UA) nas 
bateladas 2 e 3, em relação ao ensaio SI-BR2. Conseqüentemente o valor da produção específica $\left(R_{\text {esp }}\right)$ foi também ligeiramente superior no ensaio SI-BR1, nas bateladas 1 e 2 , tendo-se atingido um valor de aproximadamente 0,87 UA/(g/L) para a terceira batelada.

Observa-se também, conforme os valores apresentados na Tabela 4.2, que os valores de produtividade em células e produtividade em retamicina para as bateladas 2 e 3 do ensaio SI-BR1, foram ligeiramente superiores às bateladas do ensaio SI-BR2, respectivamente. No entanto, quando se comparam os valores de produtividade da batelada $1 \mathrm{com}$ a batelada 2 , de ambos os ensaios, observa-se que houve um aumento significativo nestes parâmetros $\left(P_{X}\right.$ e $\left.P_{R}\right)$, conforme também observado por Azevedo (2005).

Quando são comparados os resultados obtidos em biorreator em bateladas repetidas com os de Azevedo (2005), em erlenmeyer, observa-se que foram obtidos maiores valores de produção específica $\left(R_{\text {esp }}\right)$ para os ensaios em biorreator, que foram de 0,87 e 0,46 UA/(g/L) para a batelada 3 dos ensaios SI-BR1 e SI-BR2, respectivamente, enquanto que foi obtido na batelada 3 do ensaio em incubador rotativo um valor de $0,23 \mathrm{UA} /(\mathrm{g} / \mathrm{L})$.

Estes resultados tornam evidente que as melhores condições de transferência de oxigênio no biorreator, em comparação ao cultivo em incubador rotativo, são de importância significativa e afetam a produção de forma positiva, conforme já observado no trabalho de Martins (2001) e discutido anteriormente no item 4.1, para os ensaios sob diferentes condições de transferência de oxigênio.

Assim, é possível concluir que a produção de retamicina por Streptomyces olindensis imobilizado em gel de alginato em sistema de bateladas repetidas no biorreator cesta, apresentou-se como uma boa alternativa para este processo, tendo em vista que foram obtidas altas concentrações de produto no meio, o que é de particular importância no processo de produção de antibióticos, devido ao alto custo de purificação destes. Porém, neste caso, ainda será necessário que seja contornado o problema de acúmulo de células no biorreator cesta, a fim de que seja possível a execução de um número maior de bateladas repetidas. 


\subsubsection{Ensaios contínuos em biorreator tipo cesta}

\subsubsection{Ensaio contínuo com alta vazão específica de alimentação}

Conforme descrito no item 3.4.4.4, foram realizados ensaios contínuos sob diferentes vazões específicas de alimentação $\left(0,2\right.$ e $\left.0,05 \mathrm{~h}^{-1}\right)$. 0 primeiro ensaio realizado foi operado com $D=0,2 h^{-1}(\mathrm{Cl}-02-30)$, que era uma condição mais favorável operacionalmente, tendo em vista que o tempo de residência é mais curto e o estado estacionário seria estabelecido mais rapidamente.

O início da alimentação foi efetuado após uma fase descontínua de 30 horas, tempo no qual as células encontravam-se no final da fase de crescimento, com base na cinética do ensaio SI-500.

A figura 4.11, a seguir, apresenta os resultados obtidos neste ensaio, podendo-se observar que o estado estacionário foi estabelecido rapidamente, a partir de aproximadamente 12 horas após o início da alimentação (cerca de 2,4 tempos de residência).

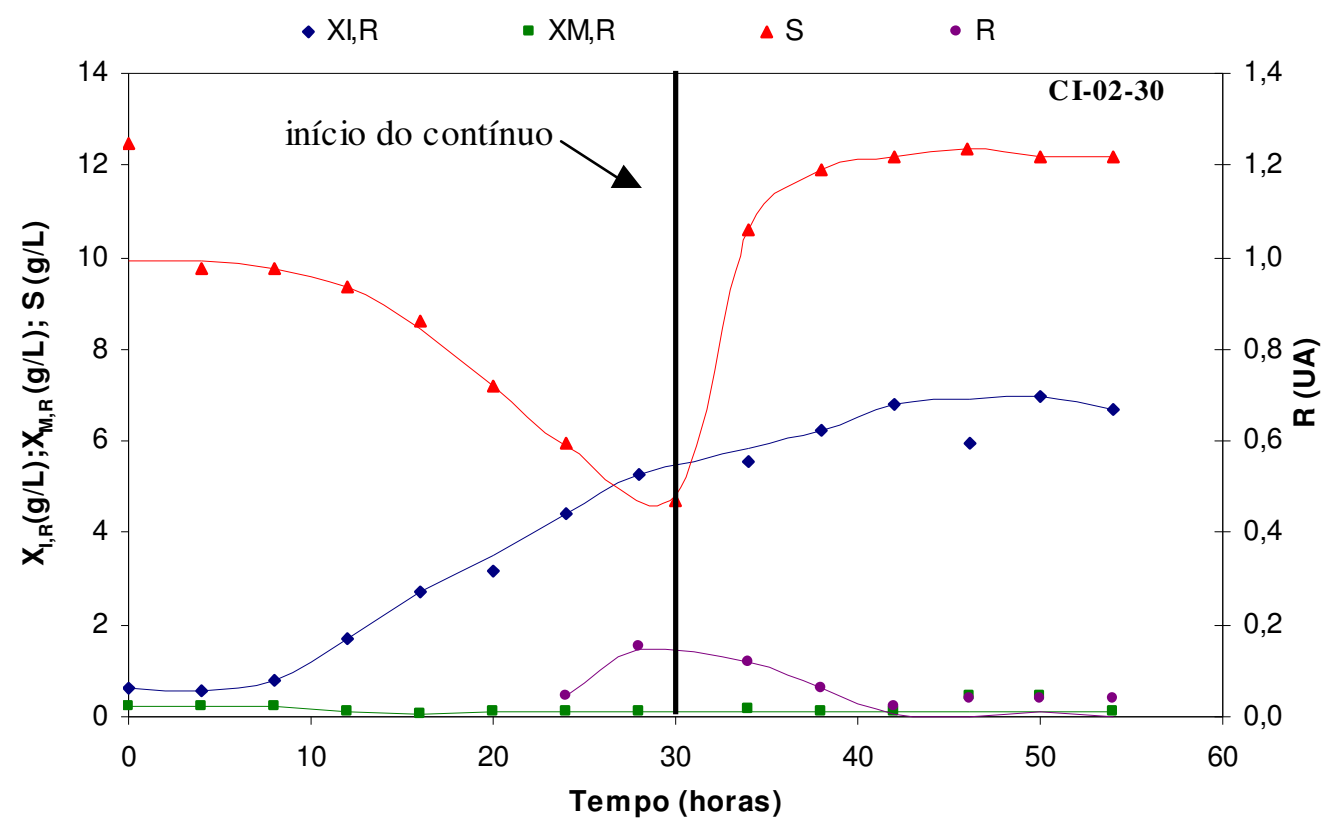

Figura 4.11 - Concentração celular imobilizada $\left(X_{I, R}\right)$ e livre $\left(X_{M, R}\right)$, concentração de glicose residual $(S)$ e produção de retamicina $(R)$ em função do tempo no ensaio $\mathrm{Cl}-02-30$. 
Pela figura 4.11 observa-se que no início da alimentação a concentração celular imobilizada e a concentração de glicose (cerca de 5,25 e 4,7 g/L, respectivamente) encontravam-se nos mesmos níveis do ensaio SI-500. Após o início da alimentação a concentração celular imobilizada apresentou um aumento, estabilizando-se em torno de 6,8 $\mathrm{g} / \mathrm{L}$ após 12 horas de alimentação. Não foi observado crescimento de células livres no meio devido à alta vazão específica de alimentação $\left(D=0,2 \mathrm{~h}^{-1}\right)$, próximo ao valor do $\mu_{\max }$ de crescimento de $S$. olindensis ICB20, observado no ensaio com células livres (SL-500).

Verificou-se também, neste ensaio, que houve um acúmulo de glicose no meio, após o início da alimentação, indicativo de uma velocidade de fornecimento de glicose ( $\mathrm{g} / \mathrm{L}$.h) maior do que a velocidade de consumo. A concentração de glicose estabilizou-se em torno de $12 \mathrm{~g} / \mathrm{L}$ a partir de 38 horas de cultivo, valor este próximo ao do meio de alimentação que era de $13,3 \mathrm{~g} / \mathrm{L}$, confirmando um consumo excessivamente lento de glicose.

Com relação à produção da retamicina, após 24 horas de cultivo observou-se a mudança de coloração do meio, caracterizando o início da produção, porém após o início da alimentação, a produção foi afetada negativamente, o que pode ser explicado pela alta vazão específica de alimentação $\left(D=0,2 \mathrm{~h}^{-1}\right)$. $O$ desfavorecimento da produção da retamicina também foi observado no trabalho de Pamboukian (2003) em seus ensaios contínuos com S.olindensis, quando foi aplicada uma alta vazão específica de alimentação (Valores de D superiores a $\left.0,1 \mathrm{~h}^{-1}\right)$.

\subsubsection{Ensaios contínuos com baixa vazão específica de alimentação}

A figura 4.12 apresenta os resultados referentes ao ensaio realizado com vazão específica de alimentação de $0,05 \mathrm{~h}^{-1}$ (Cl-005-30), iniciou-se a alimentação com 30 horas de cultivo.

Tendo em vista os resultados do ensaio $\mathrm{Cl}-02-30$, no qual se obteve uma cinética da fase descontínua similar ao ensaio SI-500, foram retiradas amostras apenas após 24 horas de cultivo, a fim de se evitar possíveis contaminações durante 
a retirada de amostra. Porém, diferentemente do ensaio anterior, a glicose ainda se encontrava em uma concentração de cerca de 7,5 g/L após 30 horas de cultivo, valor que se manteve constante até cerca de 30 horas após o início da alimentação. Por sua vez, a concentração de células imobilizadas atingiu cerca de $6 \mathrm{~g} / \mathrm{L}$ na fase inicial descontínua do cultivo, assim como no ensaio SI-500. Observou-se também que a partir de cerca de 20 horas do início do processo contínuo, ocorreu uma liberação das células imobilizadas para o meio de cultivo, aumentando o valor da concentração de células livres $\left(X_{M, R}\right)$, tendo atingido cerca de $3 \mathrm{~g} / \mathrm{L}$ ao final do ensaio. Conseqüentemente, o consumo de glicose passou a ser maior a partir desse instante (cerca de 20 horas após início da alimentação), resultando num decréscimo acentuado da concentração de glicose, visto que o consumo de glicose pelas células livres é mais rápido do que pelas imobilizadas, conforme discutido anteriormente nos ensaios comparativos entre células livres e imobilizadas (SL-500 e SI-500).

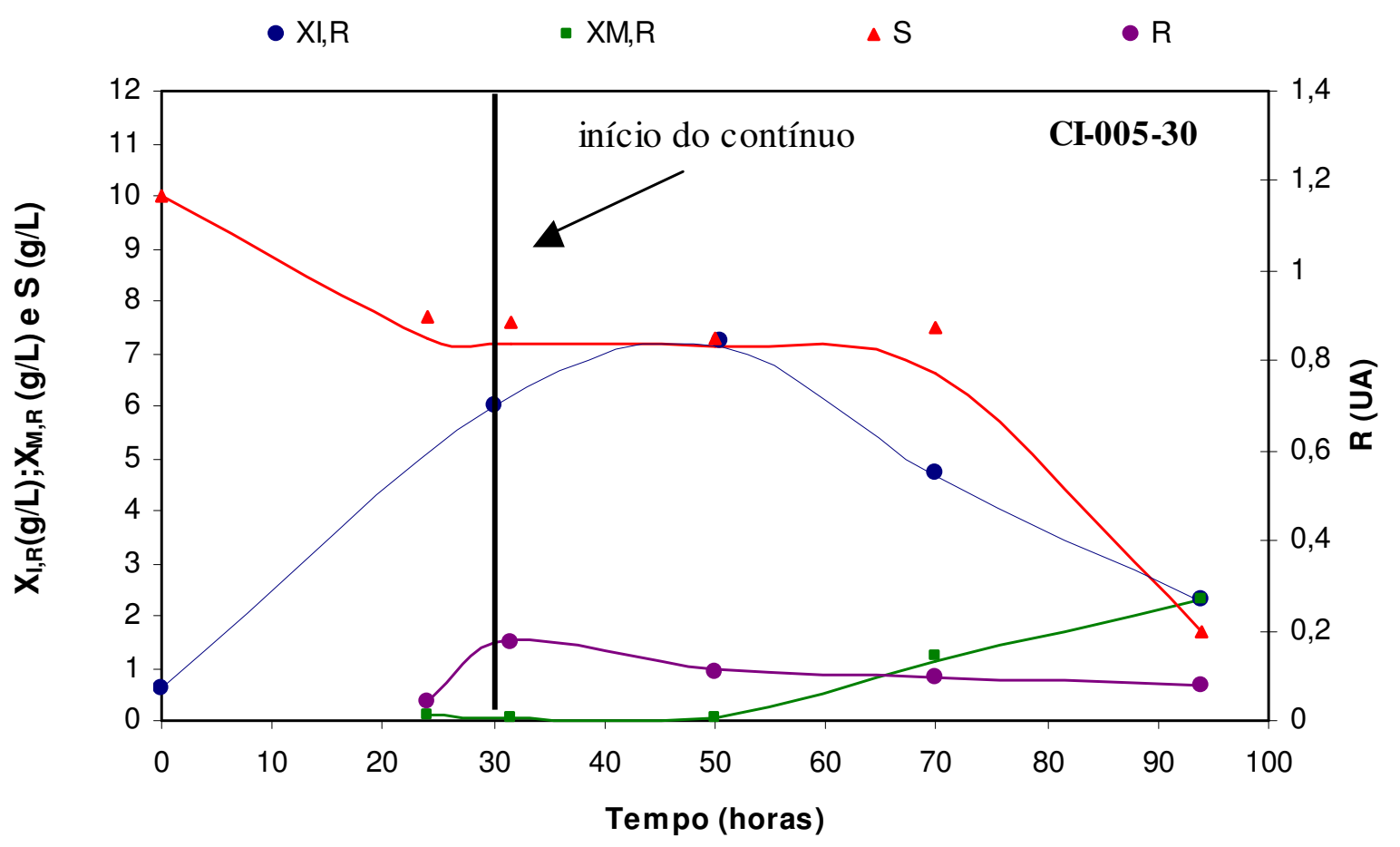

Figura 4.12 - Concentração celular imobilizada (XI,R) e livre (XM,R), concentração de glicose residual $(S)$ e produção de retamicina $(R)$ em função do tempo no ensaio Cl-005-30. 
Com relação à produção da retamicina observou-se que após o início da alimentação não houve aumento no valor da absorbância, tendo-se mantido em apenas cerca de 0,1 UA.

Depois de decorridos 3 tempos de residência (60 horas após o início do processo contínuo) não se observou o estabelecimento de um estado estacionário. Isto ocorreu, provavelmente, devido ao desprendimento das células do gel para o meio, ocasionando uma instabilidade no sistema. Tendo em vista que a produção de retamicina apresentava um valor pouco significativo (cerca de 0,1 UA), optou-se por encerrar o ensaio neste instante.

Foi então realizado um terceiro ensaio contínuo, também com $D=0,05 \mathrm{~h}^{-1}$ (Cl-005-72), sendo que neste, pretendeu-se iniciar a alimentação apenas quando a concentração de glicose já estivesse próxima de se esgotar e a produção da retamicina fosse significativa (condição de baixo valor de $\mu_{\mathrm{x}}$ e alto valor de $\mu_{\mathrm{P}}$ ), o que não ocorreu no Cl-005-30, já que os valores de absorbância ainda eram baixos no início do processo contínuo. Iniciou-se, portanto, a alimentação após uma fase descontínua de 72 horas, conforme indicado na figura 4.13, a seguir.

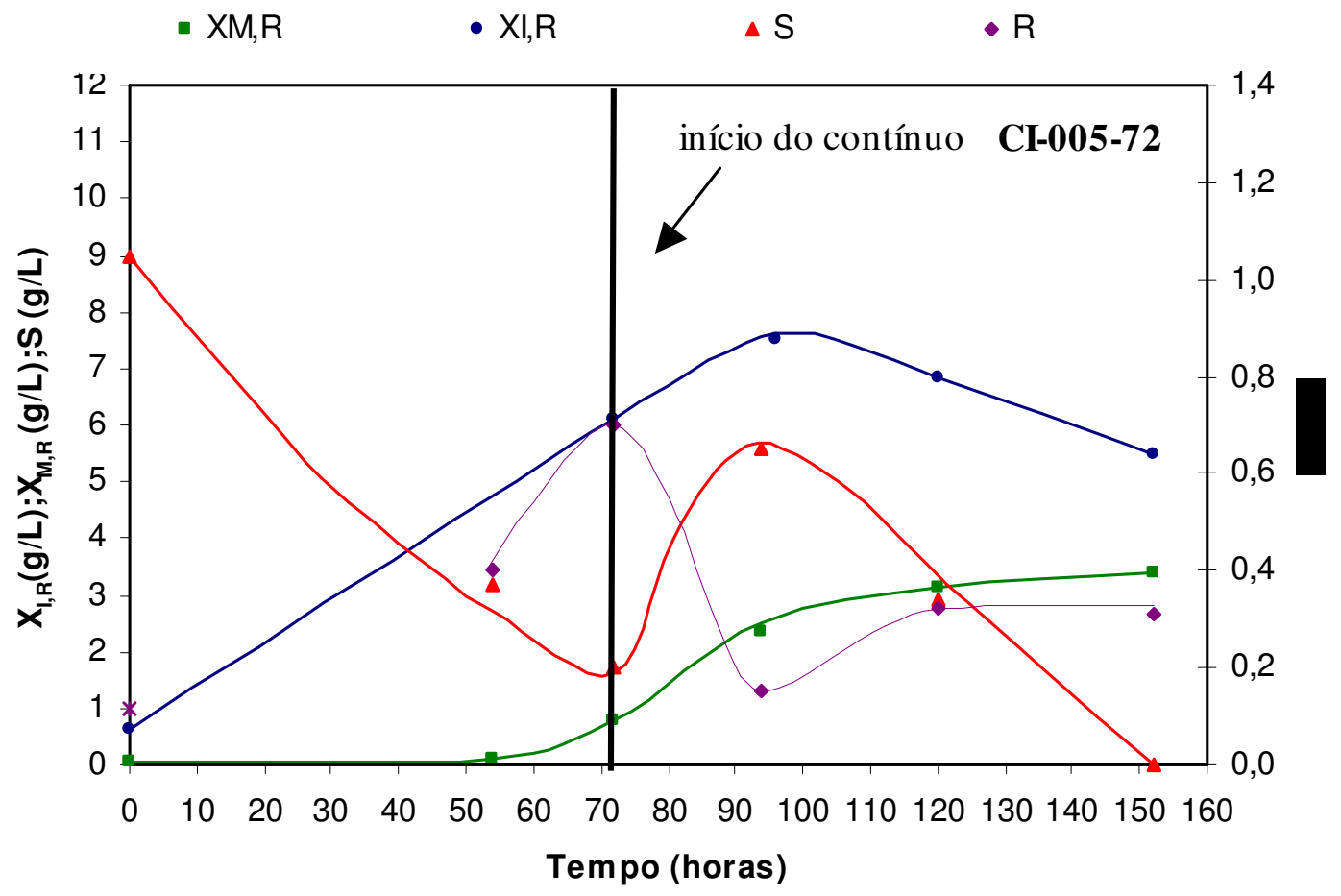

Figura 4.13 - Concentração celular imobilizada $\left(X_{I, R}\right)$ e livre $\left(X_{M, R}\right)$, concentração de glicose residual $(S)$ e produção de retamicina $(R)$ em função do tempo no ensaio Cl-005-72. 
Observa-se pela figura 4.13 que, no instante inicial do processo contínuo, a concentração de células livres $\left(X_{M, R}\right)$ encontrava-se em torno de $1 \mathrm{~g} / \mathrm{L}$, aumentando a partir de então, até atingir cerca de $5 \mathrm{~g} / \mathrm{L}$. A alta concentração celular no meio de cultivo acabou ocasionando a adesão das células na cesta, fenômeno já ocorrido nos ensaios em bateladas repetidas, conforme descrito no item 4.1.2, e portanto, inviabilizou a continuidade do ensaio, devido a não homogeneidade do caldo, como observado na figura 4.14 .

Pode-se ainda observar, pela figura 4.13, que após o início da alimentação a produção da retamicina foi desfavorecida; provavelmente, devido a estes problemas operacionais encontrados, já que esta se encontrava em torno de 0,7 UA no instante de início do processo contínuo, tendo decrescido até cerca de 0,2 UA e aumentado posteriormente, até estabilizar em torno de 0,4 UA. Por sua vez, a glicose apresentou um acúmulo até cerca de 20 horas de processo contínuo, sendo completamente consumida até a finalização do ensaio, após 80 horas de processo contínuo (cerca de três tempos de residência), apesar de não ter se estabelecido um estado estacionário até então.

Diferentemente dos ensaios realizados por Pamboukian (2003), a produção da retamicina por células de $S$. olindensis em cultivo contínuo sob baixa velocidade específica de crescimento, apresentou baixos valores de produção, além de dificuldades operacionais que inviabilizaram a continuidade dos ensaios. Por isso, decidiu-se dar prosseguimento à próxima etapa do presente trabalho, com a realização de ensaios em biorreator coluna de bolhas, na expectativa de que neste outro tipo de biorreator não se observem as dificuldades operacionais encontradas com o biorreator tipo cesta.
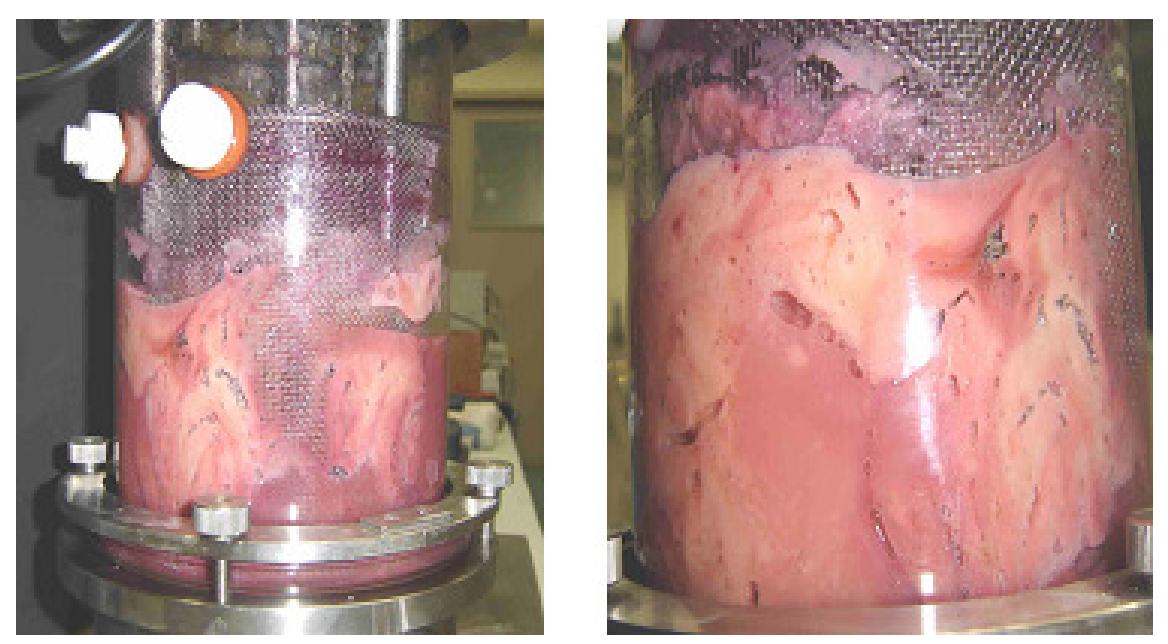

Figura 4.14 - Ensaio Cl-005-72 após decorridas 80 horas de processo contínuo. 


\subsection{Ensaios no biorreator coluna de bolhas}

4.2.1. Ensaios com células imobilizadas no biorreator coluna de bolhas em batelada simples

As figuras 4.15 a 4.18 , a seguir, apresentam os resultados dos ensaios com células de Streptomyces olindensis ICB20 imobilizadas em gel de alginato no biorreator coluna de bolhas sob diferentes vazões de aeração (1, 2 e $3 \mathrm{vvm}$ ), de acordo com a Tabela 3.2 (Capítulo 3 - Materiais e Métodos).

Os dados de concentração celular serão apresentados em termos de concentração celular total $\left(X_{T}\right)$, tendo em vista que foram observados baixos valores de concentração celular livre.

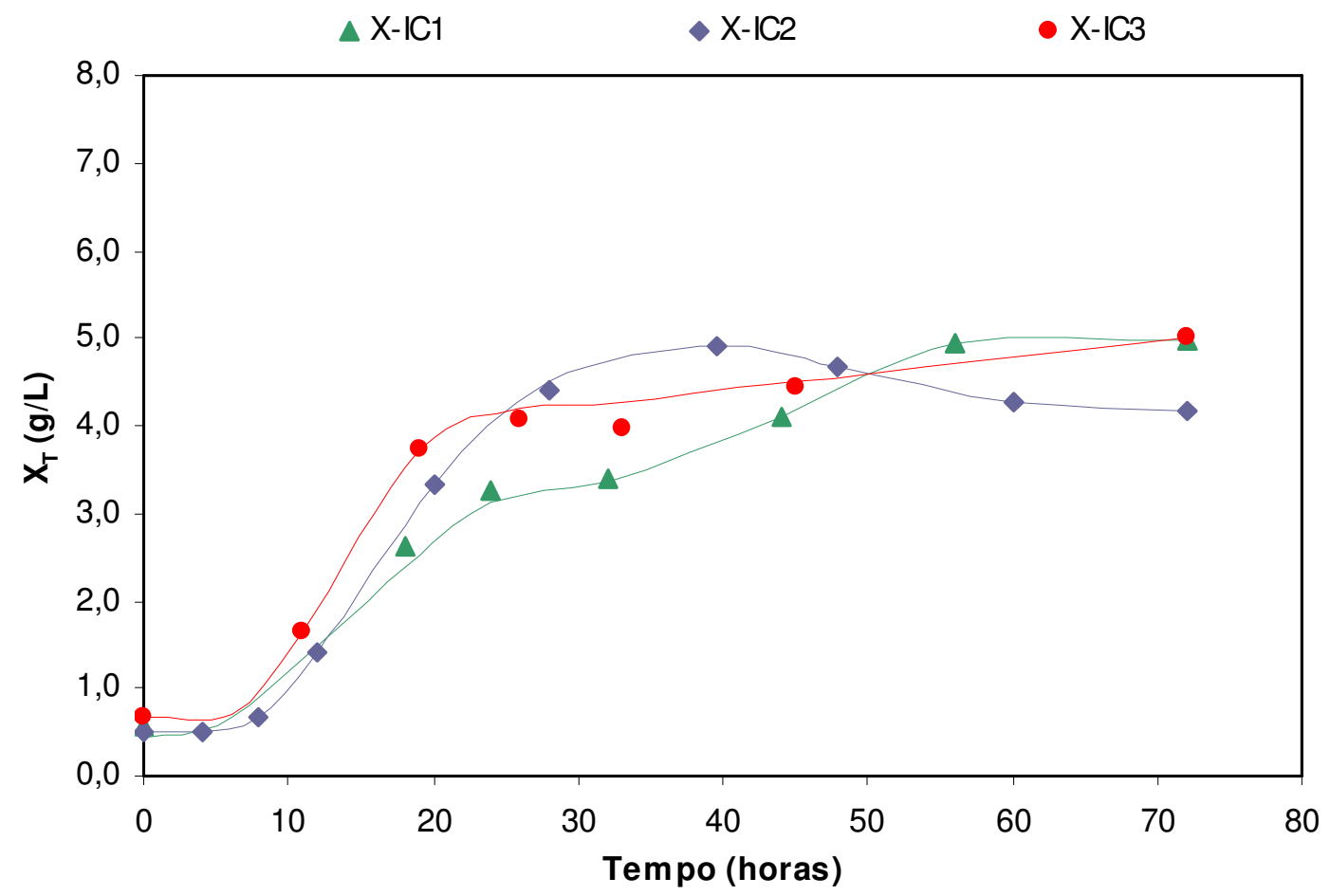

Figura 4.15 - Concentração celular total $\left(X_{T}\right)$ em função do tempo de cultivo nos ensaios com células de $S$. olindensis imobilizadas sob diferentes vazões de aeração (IC1- 1 vvm, IC2- 2 vvm e IC3- 3 vvm) 


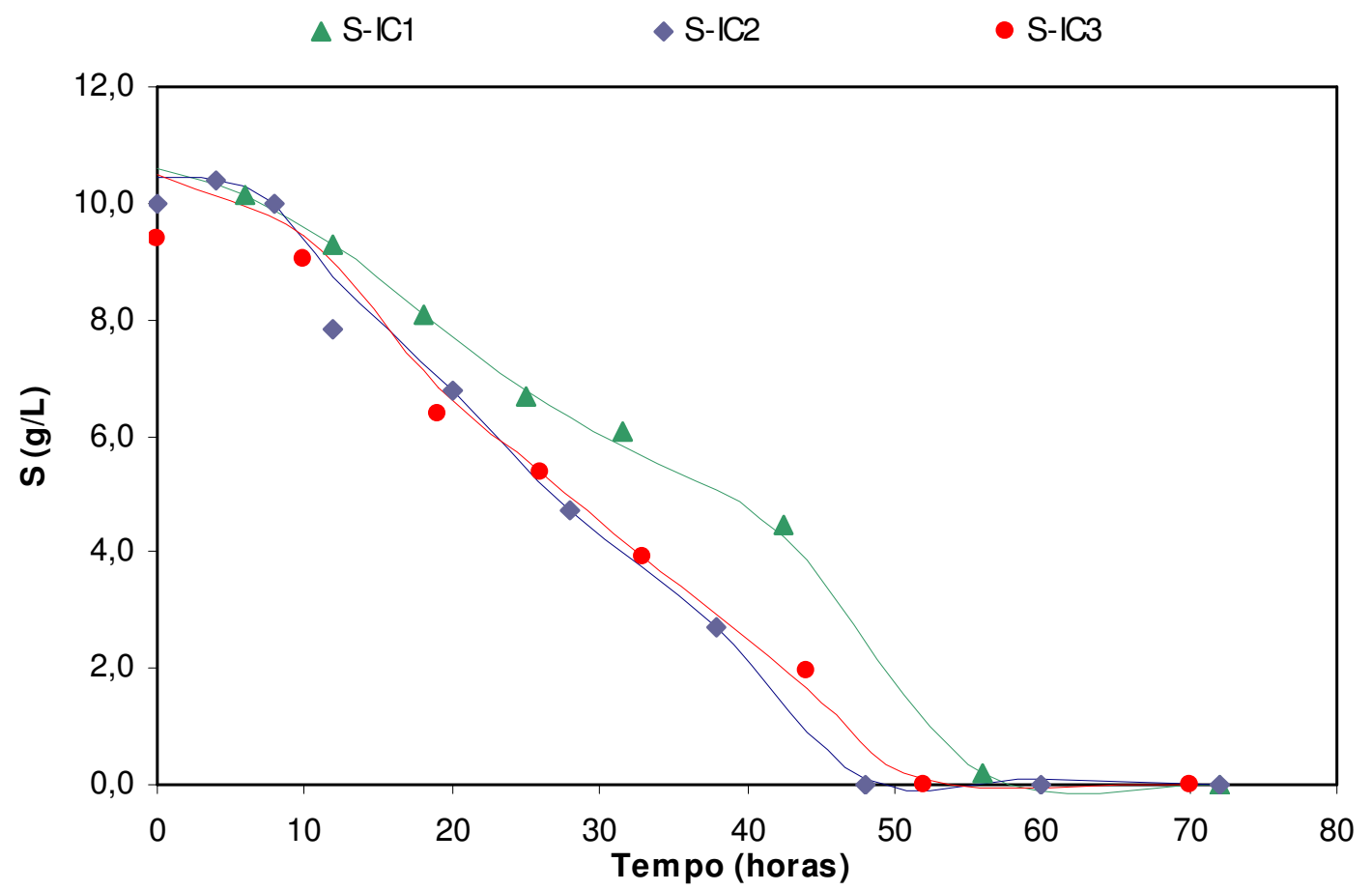

Figura 4.16 - Concentração de glicose residual (S) em função do tempo de cultivo nos ensaios com células de $S$. olindensis imobilizadas sob diferentes vazões de aeração (IC1- 1 vvm, IC2- 2 vvm e IC3- 3 vvm)

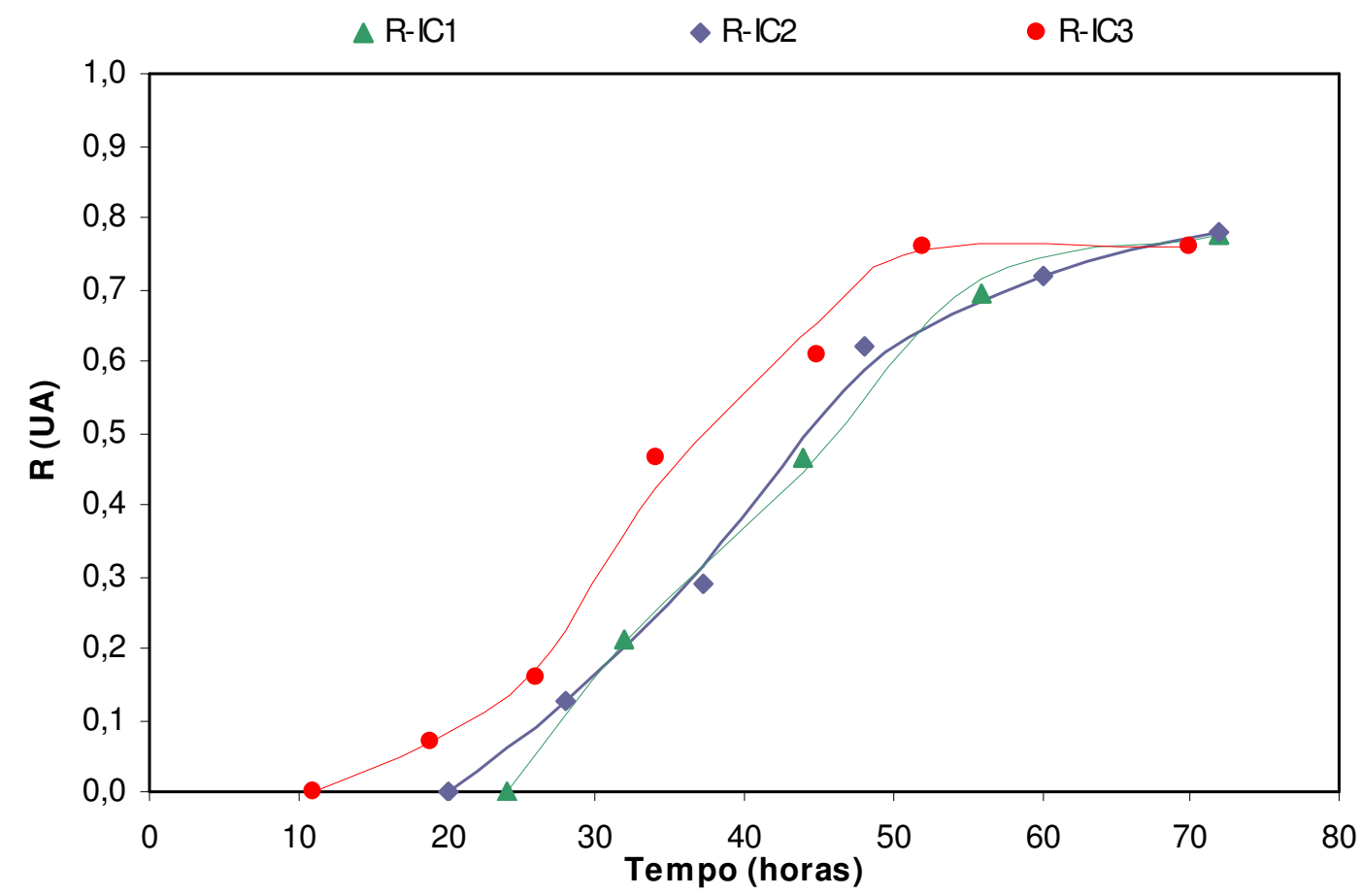

Figura 4.17 - Concentração de retamicina $(R)$ em função do tempo de cultivo nos ensaios com células de $S$. olindensis imobilizadas sob diferentes vazões de aeração (IC1- 1 vvm, IC2- 2 vvm e IC3- 3 vvm) 


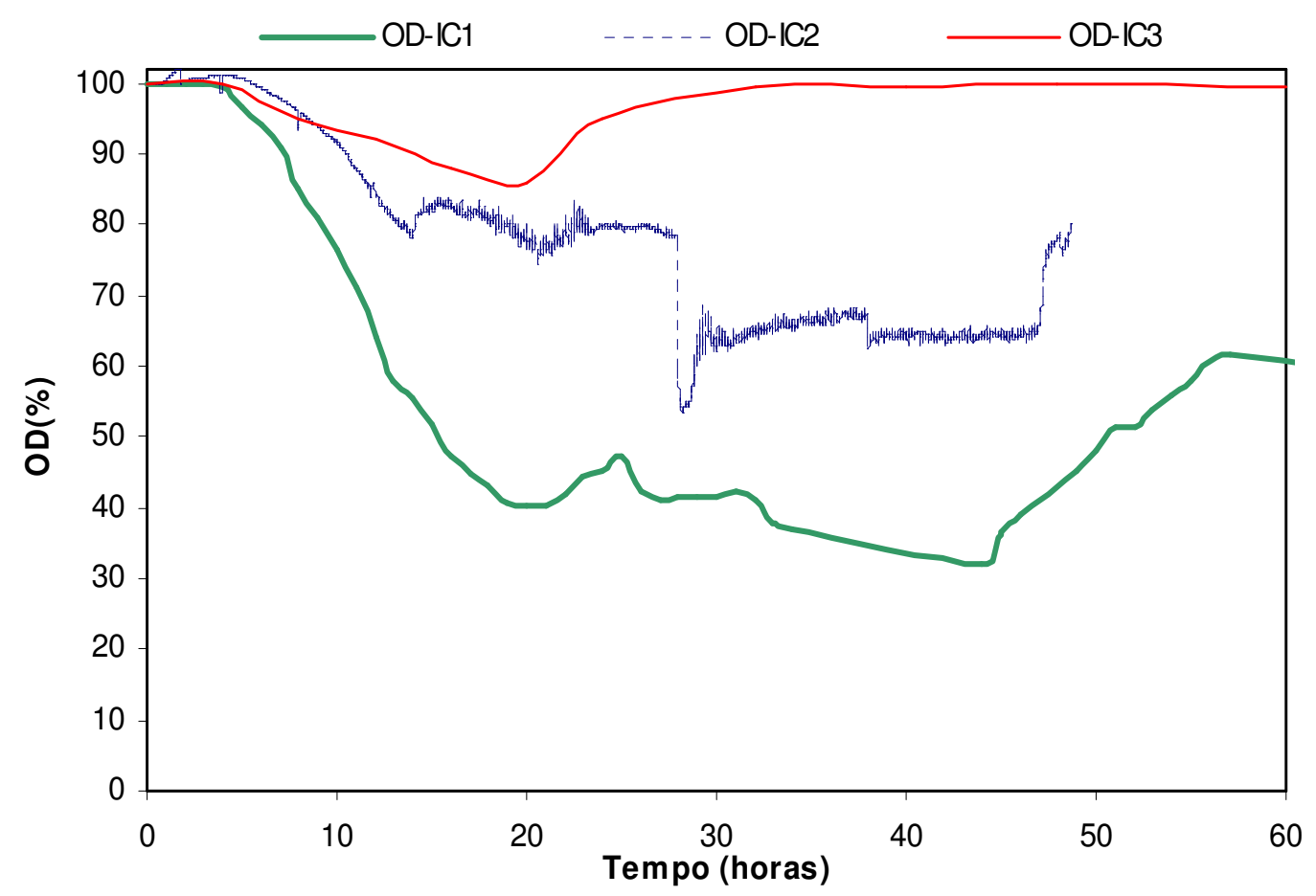

Figura 4.18 - Concentração de oxigênio dissolvido (OD) em função do tempo de cultivo nos ensaios com células de $S$. olindensis imobilizadas sob diferentes vazões de aeração (IC1- 1 vvm, IC2- 2 vvm e IC3- 3 vvm)

Os resultados obtidos nos ensaios IC1, IC2 e IC3, permitem observar que as condições de maior vazão de aeração (2 e 3 vvm) levaram a uma cinética de crescimento celular mais rápida, tendo atingido cerca de 5,0 $\mathrm{g} / \mathrm{L}$ de células em torno de 24 horas de cultivo (Figura 4.15). Ainda em relação ao crescimento celular o ensaio IC1 apresentou uma desaceleração do crescimento a partir de 18 horas e analisando estes dados em conjunto com os resultados apresentados na figura 4.18, observa-se que o ensaio IC1 apresentou concentrações de oxigênio dissolvido menores que $50 \%$ a partir desse instante, sendo esta condição desfavorável para o crescimento celular, enquanto que nos ensaios IC2 e IC3 a concentração de oxigênio dissolvido manteve-se acima de $60 \%$ durante todo o cultivo. Como comentado anteriormente, nestes ensaios foram observados baixos valores de concentração celular livre $\left(X_{M, R}\right)$, a qual atingiu em média para os três ensaios, cerca de $1 \mathrm{~g} / \mathrm{L}$, como ilustra a figura 4.19 , a seguir, para o ensaio IC1. 


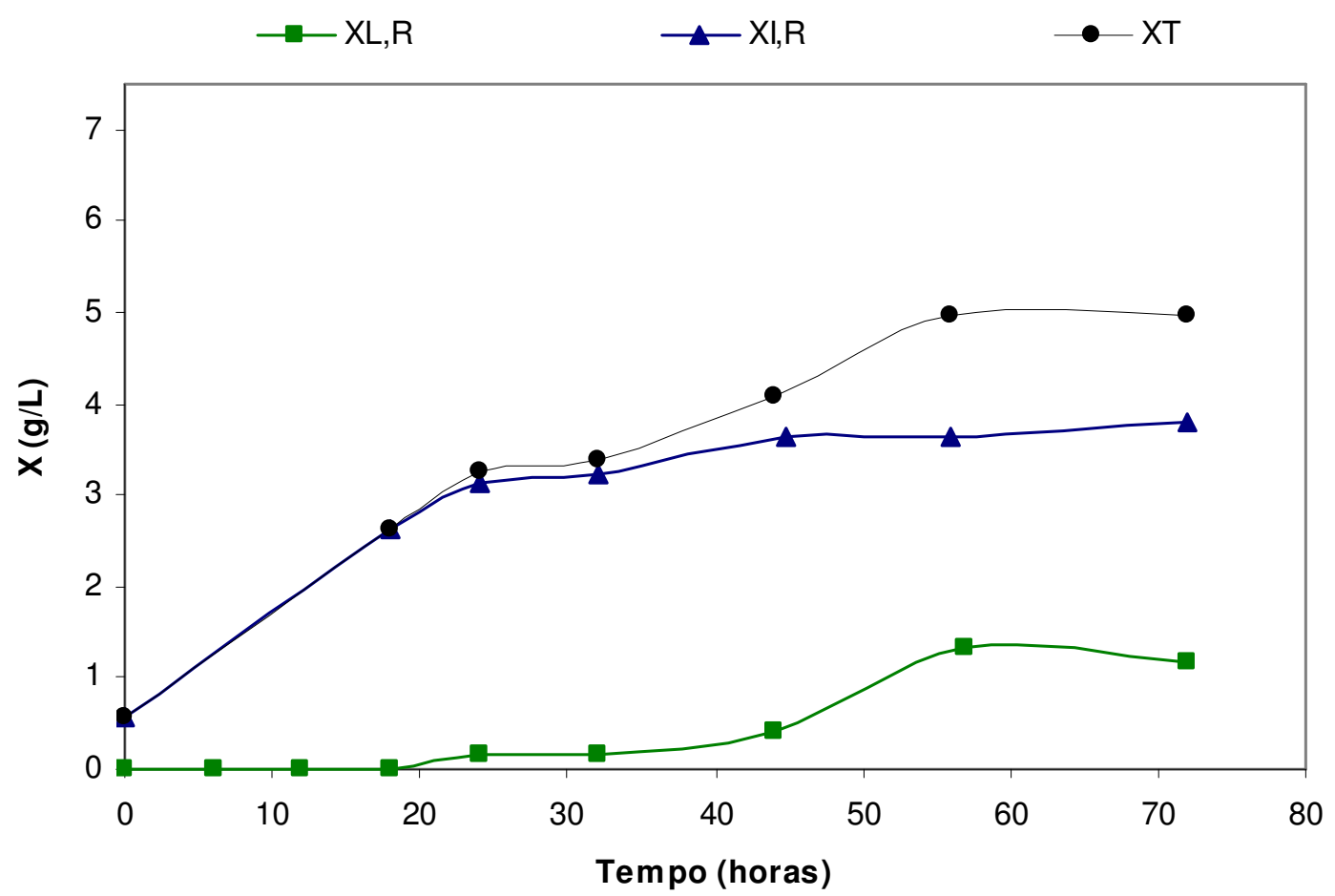

Figura 4.19 - Concentração celular imobilizada $\left(\mathrm{X}_{\mathrm{I}, \mathrm{R}}\right)$, livre $\left(\mathrm{X}_{\mathrm{M}, \mathrm{R}}\right)$ e total $\left(\mathrm{X}_{\mathrm{T}}\right)$ em função do tempo no ensaio IC1.

Em relação ao consumo de glicose nos ensaios IC1, IC2 e IC3 (Figura 4.16), seu esgotamento ocorreu em torno de 50 horas de cultivo para todos os cultivos, tendo sido consumida um pouco mais lentamente no ensaio IC1, o que se deve ao crescimento também mais lento neste ensaio.

Comparando-se estes ensaios em relação à produção da retamicina (Figura 4.17) observou-se que nos ensaios IC1 e IC2 atingiu-se cerca de 0,8 UA com cerca de 72 horas de cultivo, destacando-se o ensaio IC3 que apresentou uma cinética de produção mais rápida, atingindo a máxima produção $(0,8 \cup A)$ em 52 horas.

A partir destas observações é possível concluir que as diferentes vazões aplicadas levaram a diferentes perfis de concentração de oxigênio dissolvido no decorrer dos cultivos, porém estas diferenças não causaram influência significativa sobre o valor máximo da produção de retamicina. 
4.2.2 - Ensaios no biorreator coluna de bolhas com células livres em bateladas simples.

As figuras 4.20 a 4.23, a seguir, apresentam os resultados dos ensaios com células livres no biorreator coluna de bolhas, sob diferentes condições de aeração (LC1 - 1vvm, LC2 - 2 vvm e LC3 -3 vvm).

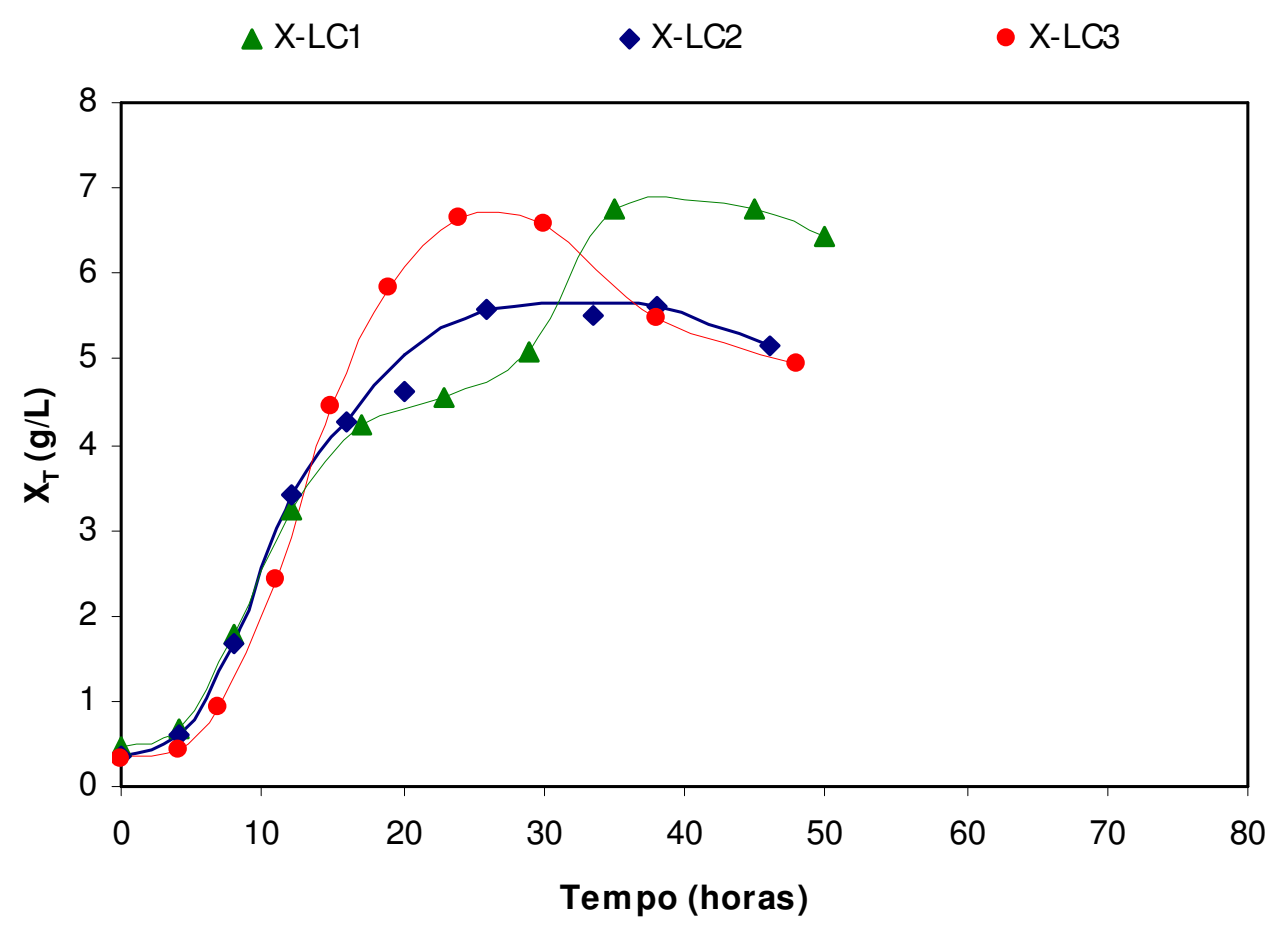

Figura 4.20 - Concentração celular total $\left(\mathrm{X}_{\mathrm{T}}\right)$ em função do tempo nos ensaios com células livres de $S$. olindensis sob diferentes vazões de aeração (LC1- 1 vvm, LC2- 2 vvm e LC3- 3 vvm) 


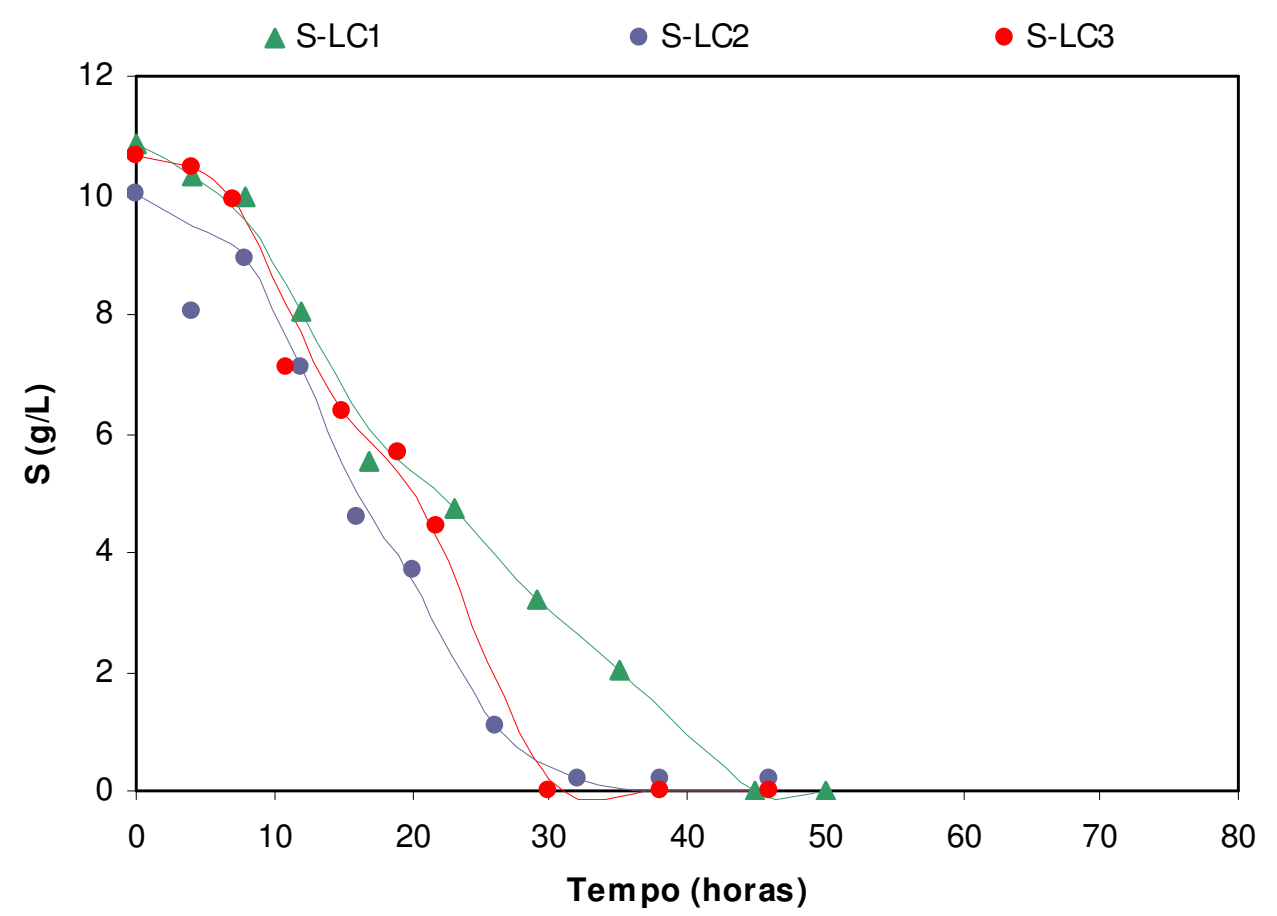

Figura 4.21 - Concentração de glicose residual (S) em função do tempo nos ensaios com células livres de $S$. olindensis sob diferentes vazões de aeração (LC1- 1 vvm, LC2- 2 vvm e LC3- 3 vvm)

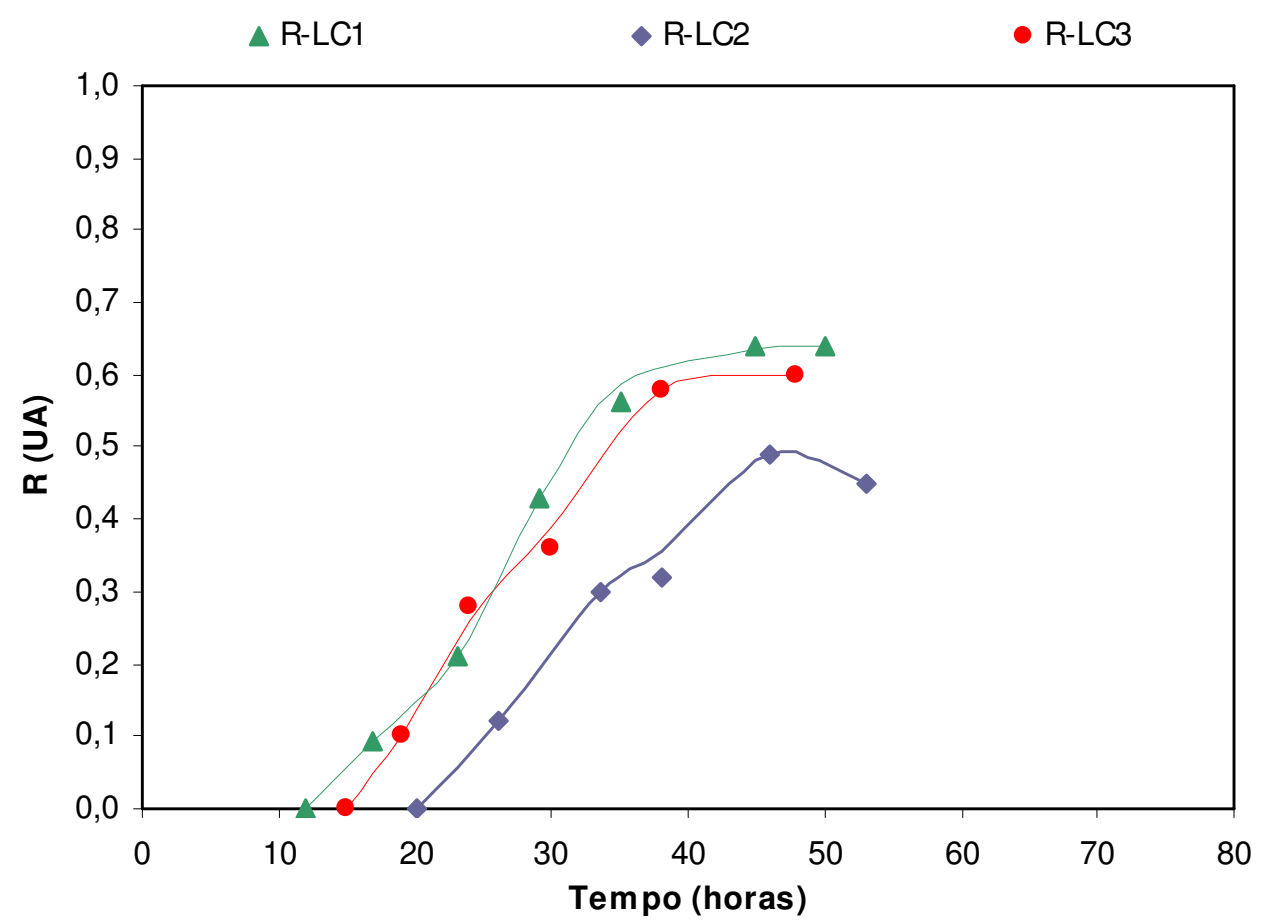

Figura 4.22 - Produção de retamicina (R) em função do tempo nos ensaios com células livres de $S$. olindensis sob diferentes vazões de aeração (LC1 - 1 vvm, LC2- 2 vvm e LC3- 3 vvm) 


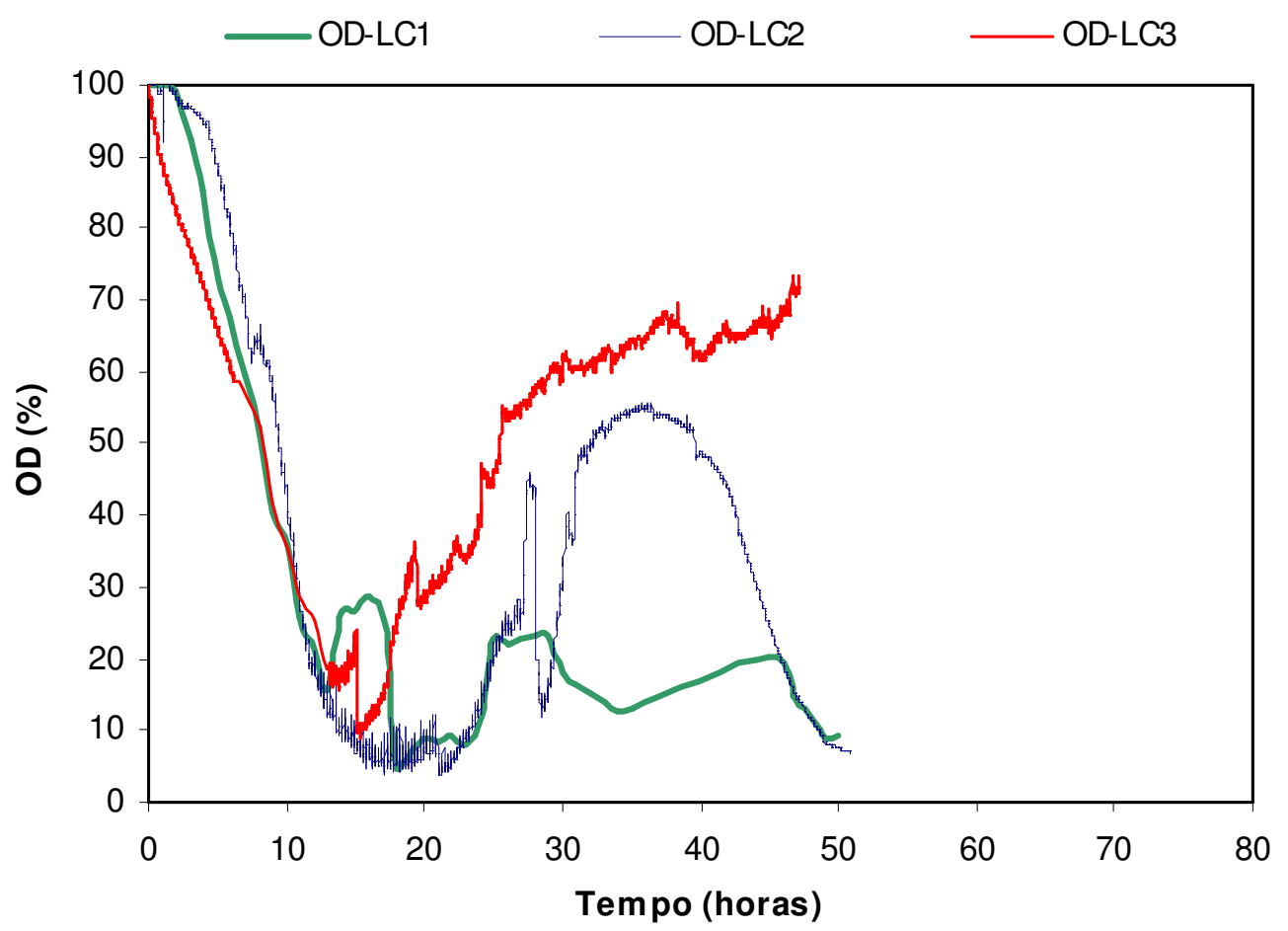

Figura 4.23 - Concentração oxigênio dissolvido (OD) em função do tempo de cultivo nos ensaios com células livres de $S$. olindensis sob diferentes vazões de aeração (LC1- 1 vvm, LC2- 2 vvm e LC3- 3 vvm)

Os resultados para os ensaios LC1, LC2 e LC3, mostraram que a condição de maior vazão de aeração ( $3 \mathrm{vvm}$ ) levou a uma cinética de crescimento celular mais rápida, tendo atingido cerca de $6,6 \mathrm{~g} / \mathrm{L}$ de células em 24 horas de cultivo.

Observa-se também que apesar da maior aeração, no ensaio LC3, os valores de oxigênio dissolvido no meio atingiram valores de cerca de $10 \%$ da saturação no período correspondente ao final da fase de crescimento celular, similarmente aos cultivos com menores valores de aeração. Estes baixos níveis de oxigênio dissolvido provavelmente estão relacionados com a morfologia e à alta viscosidade observada nos cultivos com células livres de $S$. olindensis no biorreator tipo coluna de bolhas, devido a uma condição de menor cisalhamento das células em comparação com o biorreator STR.

De acordo com a figura 4.21, observa-se que a glicose se esgotou por volta de 30 horas de cultivo nos ensaios LC2 e LC3 e seu consumo foi mais lento para 0 
ensaio LC1, tendo-se esgotado apenas por volta de 48 horas de cultivo, comportamento este coerente com as cinéticas de crescimento celular.

Em relação à produção de retamicina (figura 4.22), foram obtidos valores de produção de retamicina similares para os ensaios LC1 e LC3, os quais atingiram cerca de 0,60 UA após 40 horas de cultivo. Esta menor produção da retamicina nos ensaios com células livres, em relação aos ensaios com células imobilizadas, pode ser explicada pela baixa concentração de oxigênio dissolvido (menor que 20\%) a partir de 12 horas de cultivo (Figura 4.23), o que pode ter afetado negativamente a produção, como já observado em trabalhos anteriores (MARTINS, 2001). Conforme comentado anteriormente item 4.2.1, nos ensaios com células imobilizadas os níveis de oxigênio dissolvido foram significativamente maiores (Figura 4.18), o que se deve pela cinética de crescimento celular mais lenta, assim como, pela menor viscosidade do líquido, devido à ausência de células livres, e com isso, uma melhor de transferência de oxigênio.

Convém observar por último, conforme a figura 4.22, que a cinética de produção de retamicina foi mais lenta no ensaio LC2, com 2 vvm de aeração, atingindo-se um valor máximo de absorbância um pouco inferior (em torno de 0,5 UA). Todavia, não se encontrou uma justificativa para esta diferença, tendo-se inclusive repetido o ensaio nessa condição e o resultado foi confirmado.

\subsubsection{Comparação entre os ensaios realizados no biorreator coluna de bolhas}

A figura 4.24 apresenta as curvas de In (X) em função do tempo, a partir das quais foram obtidos os valores de velocidade específica máxima de crescimento $\left(\mu_{\max }\right)$ para os ensaios no biorreator coluna de bolhas, os quais são apresentados na tabela 4.3.

Os valores de velocidade específica máxima de crescimento celular $\left(\mu_{\max }\right)$, observados com células imobilizadas, foram consideravelmente inferiores, comparando-se os ensaio com células livres e imobilizadas sob as mesmas 
condições de aeração. Em média os ensaios com células livres apresentaram $\mu_{\max }$ cerca de duas vezes superior aos obtidos com células imobilizadas.
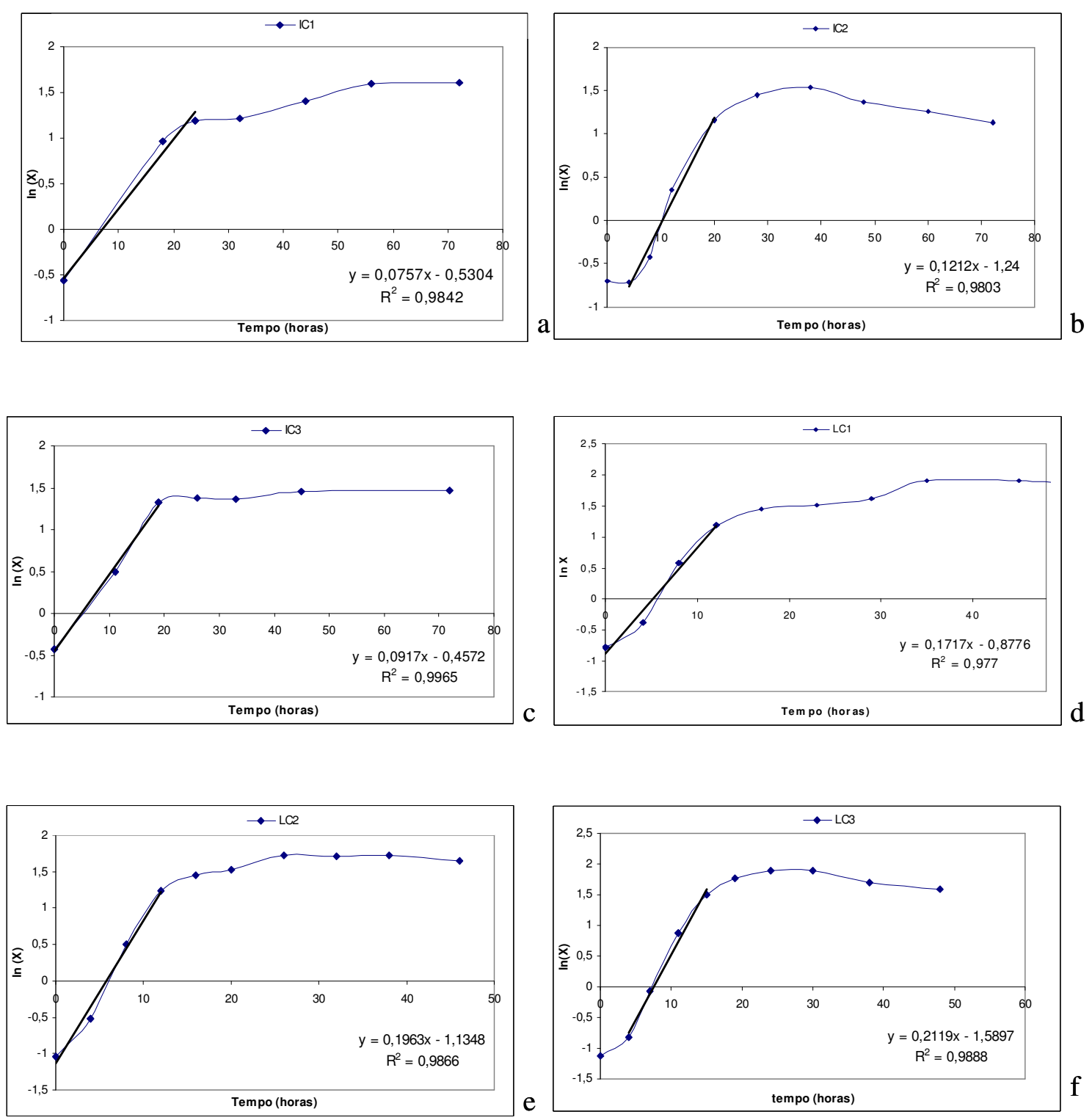

Figura 4.24 - $\ln (X)$ em função do tempo para os ensaios com células imobilizadas IC1(a), IC2 (b), IC3 (c) e com células livres LC1 (d), LC2 (e) e LC3 (f).

Os perfis de velocidades específicas de crescimento celular, consumo de substrato e produção da retamicina, obtidos através do programa Logeciel de Lissage (SIMÕES, 1994), para os ensaios com células livres e imobilizadas em coluna de bolhas, podem ser analisados a partir da figura 4.25, a seguir. 

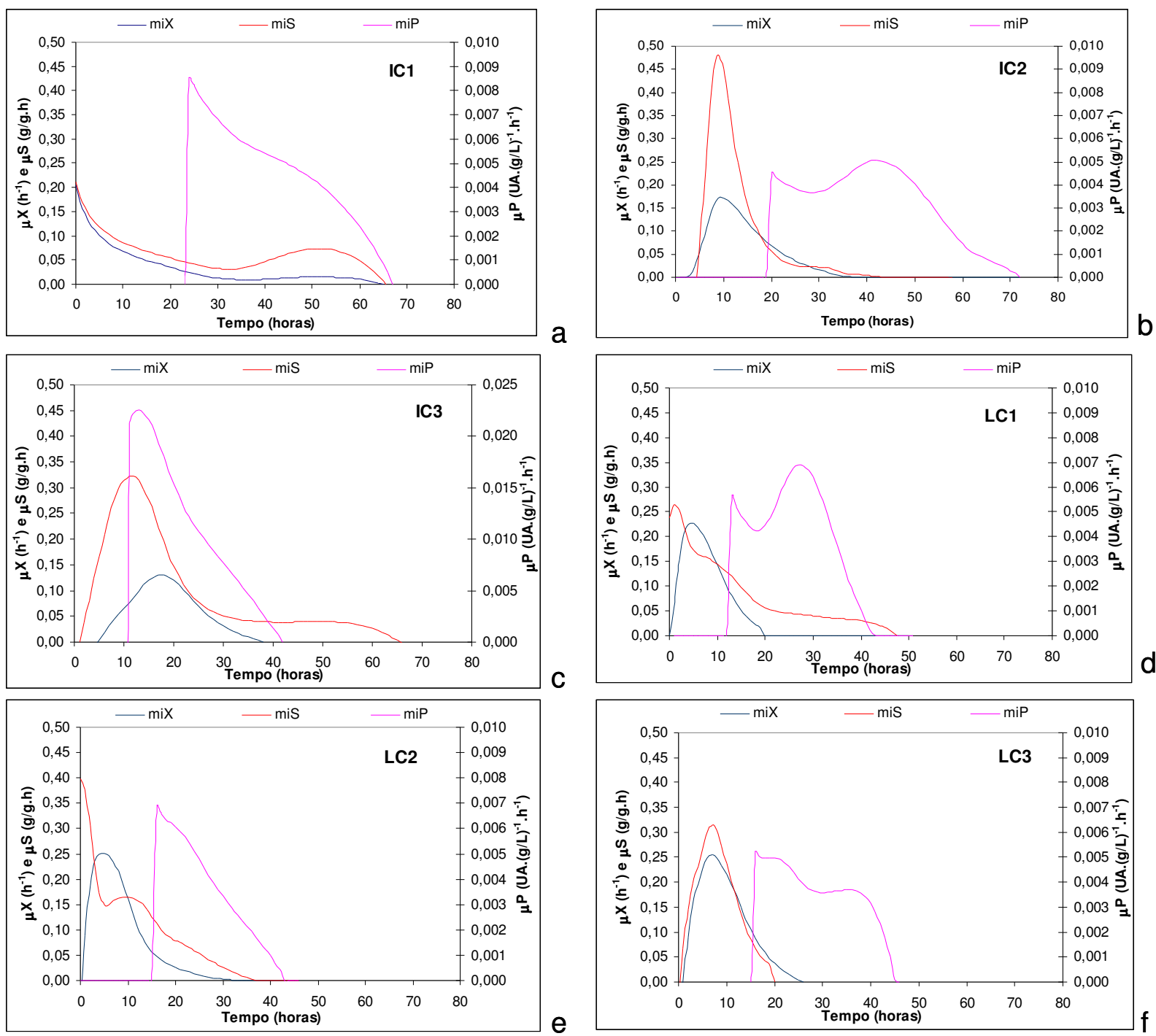

Figura 4.25 - velocidades específicas de crescimento celular $\left(\mu_{\mathrm{X}}\right)$,consumo de substrato $\left(\mu_{\mathrm{S}}\right)$ e produção de retamicina $\left(\mu_{\mathrm{P}}\right)$ em função do tempo nos ensaios com células imobilizadas IC1 (a),IC2 (b),IC3 (c) e com células livres LC1 (d),LC2 (e) e LC3 (f).

Em geral todos os ensaios apresentaram uma defasagem entre o perfil de velocidade específica de produção da retamicina em relação ao perfil da velocidade específica de crescimento celular, caracterizando o padrão bifásico, como observado anteriormente nos ensaios no biorreator cesta (item 4.1), com exceção do ensaio IC3, no qual o instante de velocidade específica máxima de produção se aproxima do instante de velocidade específica máxima de crescimento, cerca de 16 horas do cultivo, além de se observar uma interseção significativa entre as curvas, devido à antecipação do início da produção de retamicina, conforme a Figura 4.17. 
Em relação às curvas de $\mu_{\mathrm{S}}$, pode-se observar que estas acompanharam as curvas de $\mu_{\mathrm{X}}$, apresentando comportamento similar, com maiores velocidades de consumo nos ensaio IC2 e LC2 (cerca de 0,45 g/g.h), valores estes consideravelmente superiores aos observados nos ensaios em biorreator cesta (cerca de 0,20 g/g.h no ensaio SI-500), conforme apresentado anteriormente na Figura 4.7. Estes maiores valores de $\mu_{S}$ nos ensaios com células imobilizadas no reator coluna de bolhas indicam que as condições de agitação e aeração da coluna de bolhas permitiram uma melhor difusão da glicose em relação às condições no biorreator cesta, possivelmente porque a formação do leito empacotado no biorreator cesta dificultava a difusão da glicose.

A Tabela 4.3, a seguir, apresenta um resumo dos dados obtidos a partir dos ensaios no biorreator coluna de bolhas com células livres e imobilizadas de $S$. olindensis. A definição e o cálculo dos parâmetros da Tabela 4.3 encontram-se descritos nos itens 3.6.1 e 3.6.2.

Tabela 4.3 - Comparação dos ensaios no biorreator coluna de bolhas com células livres (LC1, LC2, LC3) e com células imobilizadas (IC1, IC2, IC3) de S. olindensis

\begin{tabular}{|c|c|c|c|c|c|c|}
\hline & LC1 & LC2 & LC3 & IC1 & IC2 & IC3 \\
\hline $\mathrm{X}_{\text {To }}(\mathrm{g} / \mathrm{L})$ & 0,46 & 0,35 & 0,32 & 0,60 & 0,45 & 0,65 \\
\hline $\mathrm{X}_{\mathrm{Tm}_{\mathrm{m}}(\mathrm{g} / \mathrm{L})}$ & 6,75 & 5,20 & 6,60 & 4,96 & 4,96 & 5,00 \\
\hline $\mathrm{R}_{\mathrm{m}}(\mathrm{UA})$ & 0,64 & 0,49 & 0,60 & 0,78 & 0,78 & 0,76 \\
\hline $\mathrm{t}_{\mathrm{m}}(\mathrm{h})$ & 36 & 28 & 24 & 56 & 28 & 24 \\
\hline $\mathrm{t}_{\mathrm{m}}{ }^{\prime}(\mathrm{h})$ & 45 & 45 & 40 & 72 & 72 & 52 \\
\hline $\begin{array}{c}\text { Fase } \\
\text { Exponencial } \\
(\mathrm{h})\end{array}$ & 0 a 12 & $0 \mathrm{a} 12$ & 4 a 16 & 0 a 24 & 4 a 20 & 0 a 20 \\
\hline$\mu_{\max }\left(\mathrm{h}^{-1}\right)$ & 0,172 & 0,196 & 0,212 & 0,076 & 0,121 & 0,092 \\
\hline $\mathrm{S}_{0}(\mathrm{~g} / \mathrm{L})$ & 10,8 & 11,0 & 10,9 & 11,0 & 10,2 & 9,4 \\
\hline $\mathrm{Y}_{\mathrm{X} / \mathrm{S}}(\mathrm{g} / \mathrm{g})$ & 0,582 & 0,441 & 0,576 & 0,396 & 0,442 & 0,463 \\
\hline $\mathrm{Y}_{\mathrm{R} / \mathrm{S}}(\mathrm{UA} /(\mathrm{g} / \mathrm{L}))$ & 0,059 & 0,045 & 0,055 & 0,071 & 0,076 & 0,081 \\
\hline $\mathrm{P}_{\mathrm{X}}(\mathrm{g} / \mathrm{L} . \mathrm{h})$ & 0,175 & 0,173 & 0,262 & 0,078 & 0,161 & 0,181 \\
\hline $\mathrm{P}_{\mathrm{R}}(\mathrm{UA} / \mathrm{h})$ & 0,014 & 0,011 & 0,015 & 0,011 & 0,011 & 0,015 \\
\hline$R_{\text {esp }}(\mathrm{UA} /(\mathrm{g} / \mathrm{L}))$ & 0,102 & 0,101 & 0,096 & 0,179 & 0,173 & 0,175 \\
\hline
\end{tabular}

Os resultados apresentados na Tabela 4.3 mostram que os ensaios com células livres favoreceram o crescimento celular, tendo-se em vista que foram 
observados maiores valores de concentração celular total nos ensaios LC1 e LC3 (cerca de 6,7 g/L), e conseqüentemente maiores fatores de conversão substrato à célula $(0,58 \mathrm{~g} / \mathrm{g})$. Da mesma forma, as produtividades em células foram maiores, sendo que o maior valor foi obtido para o cultivo com células livres no ensaio LC3 a $3 \mathrm{vvm}(0,262 \mathrm{~g} / \mathrm{L} . \mathrm{h})$. Em contrapartida, foram obtidos maiores valores de fator de conversão de substrato a produto $\left(\mathrm{Y}_{\mathrm{R} / \mathrm{S}}\right)$ para os ensaios com células imobilizadas, sendo o maior valor encontrado para a condição de $3 \mathrm{vvm}(0,081 \mathrm{UA} /(\mathrm{g} / \mathrm{L}))$.

Em relação à produtividade em retamicina, apesar da produção ter sido superior nos ensaios com células imobilizadas, como os ensaios com células livres apresentaram cinéticas mais rápidas, os valores de produtividade observados tiveram valores similares variando entre 0,011 e $0,015 \mathrm{UA} / \mathrm{h}$ para todos os cultivos.

A produção específica em retamicina apresentou valor médio em torno de 0,175 UA/(g/L) nos ensaios com células imobilizadas (IC1, IC2 e IC3), valor este superior ao valor médio de $0,010 \mathrm{UA} /(\mathrm{g} / \mathrm{L}$ ) obtido com células livres (LC1, LC2 e LC3), indicando que o estresse imposto pela imobilização favoreceu a síntese de metabólitos secundários, como é o caso da retamicina

Portanto, a partir dos resultados obtidos, pode-se concluir que a aplicação do processo com células imobilizadas para produção do antitumoral retamicina em biorreator coluna de bolhas mostrou ser mais adequado em comparação aos cultivos com células livres, apresentando uma maior produção da retamicina, mesmo tratando-se de ensaios em batelada simples, diferentemente do que havia sido observado para os cultivos em biorreator cesta (item 4.1).

As figuras 4.26 e 4.27 ilustram os aspectos dos ensaios com células livres (LC1) e com células imobilizadas (IC1) no biorreator coluna de bolhas, respectivamente.

A partir destas ilustrações pode-se observar a mudança da coloração do meio para a cor arroxeada nos instantes finais de ambos os ensaios, característica da presença da retamicina. Também pode-se observar que no ensaio IC1 o gel manteve-se bem distribuído em todo o leito, mesmo para os instantes finais do cultivo, que apresentavam presença de células livres. 

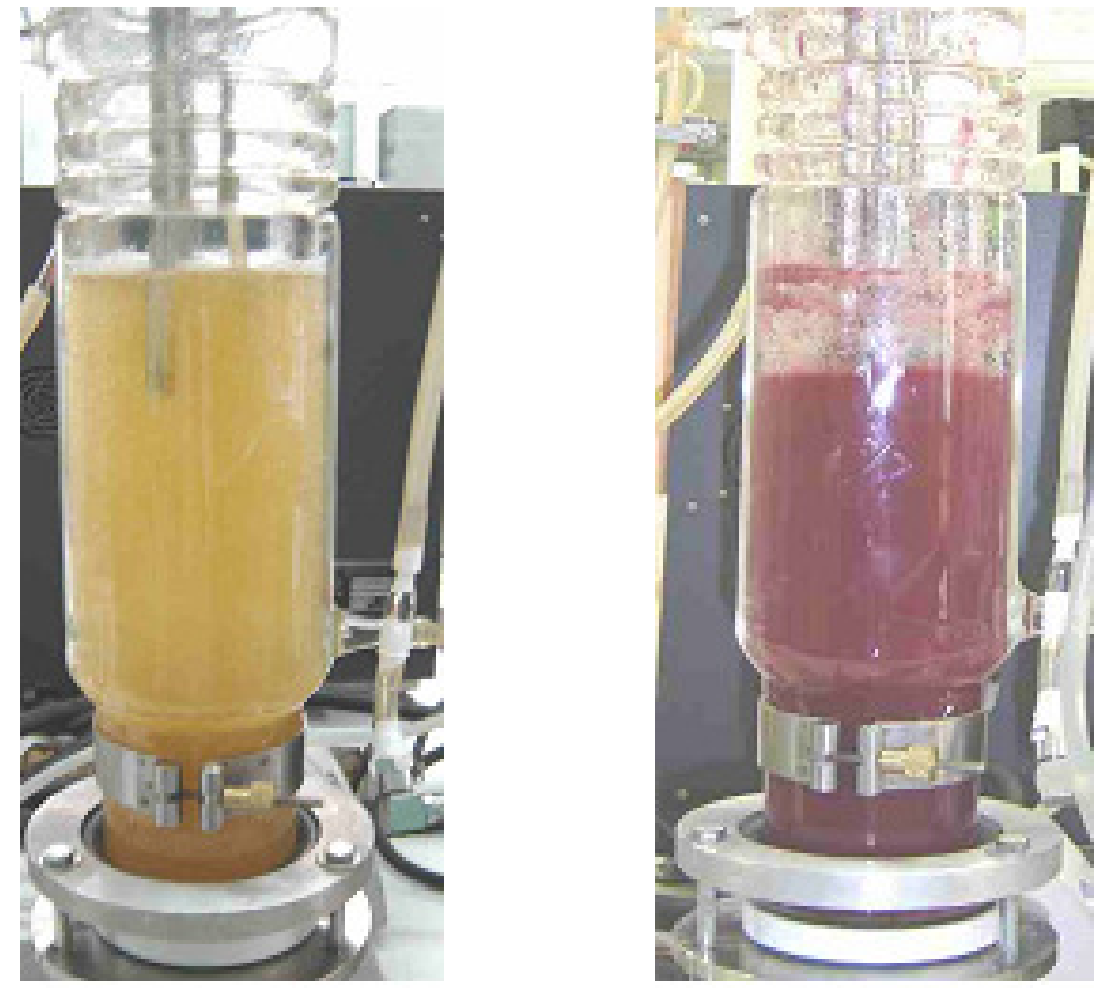

Figura 4.26 - Ensaio com células livres (LC1) no biorreator coluna de bolhas nos instantes inicial e final (50 horas), respectivamente.
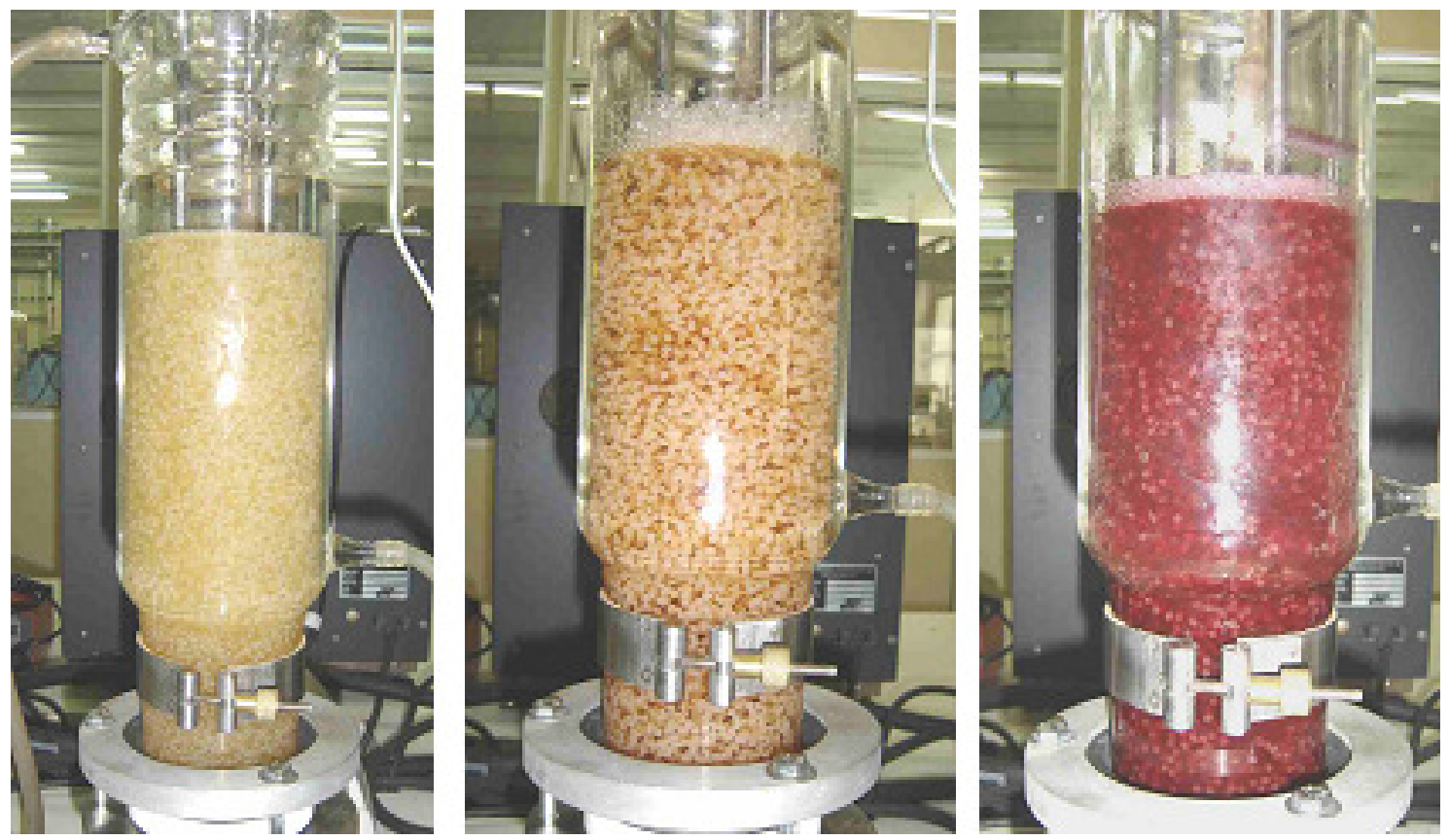

Figura 4.27 - Ensaio com células imobilizadas (IC1) no biorreator coluna de bolhas nos instantes 0, 24 e 72 horas, respectivamente. 


\subsubsection{Ensaios em bateladas repetidas no biorreator coluna de bolhas com células imobilizadas}

Os resultados obtidos no experimento no biorreator coluna de bolhas, ensaio IC-BR, em sistema de bateladas repetidas com as células imobilizadas estão apresentados nas Figuras 4.28 e 4.29, observando-se que foram realizadas um total de 14 bateladas.



Figura 4.28 - Concentração celular livre $\left(\mathrm{X}_{\mathrm{M}, \mathrm{R}}\right)$ e imobilizada $\left(\mathrm{X}_{\mathrm{I}, \mathrm{R}}\right)$ e produção de retamicina $(\mathrm{R})$ em função do tempo de cultivo no biorreator coluna de bolhas.

Analisando-se a figura 4.28 nota-se que a concentração celular livre $\left(X_{M, R}\right)$ atingiu um valor de cerca de $2 \mathrm{~g} / \mathrm{L}$ na primeira batelada e um valor médio em torno de $4 \mathrm{~g} / \mathrm{L}$ nas bateladas seguintes. Já a concentração de células imobilizadas $\left(X_{1, R}\right)$ apresentou valores máximos em torno de $4 \mathrm{~g} / \mathrm{L}$ nas bateladas 1 e 2 e decresceu nas bateladas subseqüentes, estabilizando-se em torno de $2,5 \mathrm{~g} / \mathrm{L}$ a partir da batelada 4 .

A presença de uma quantidade significativa de células livres no biorreator indicou e existência de um sistema misto de células livres e imobilizadas, ao invés de um sistema estritamente de células imobilizadas, fato este também observado 
Tavares (1998) para a produção de etanol por células imobilizadas de Saccharomyces cerevisiae e por Silva et al. (2002) em um sistema de células imobilizadas de Candida guilliermondii para a produção de xilitol.

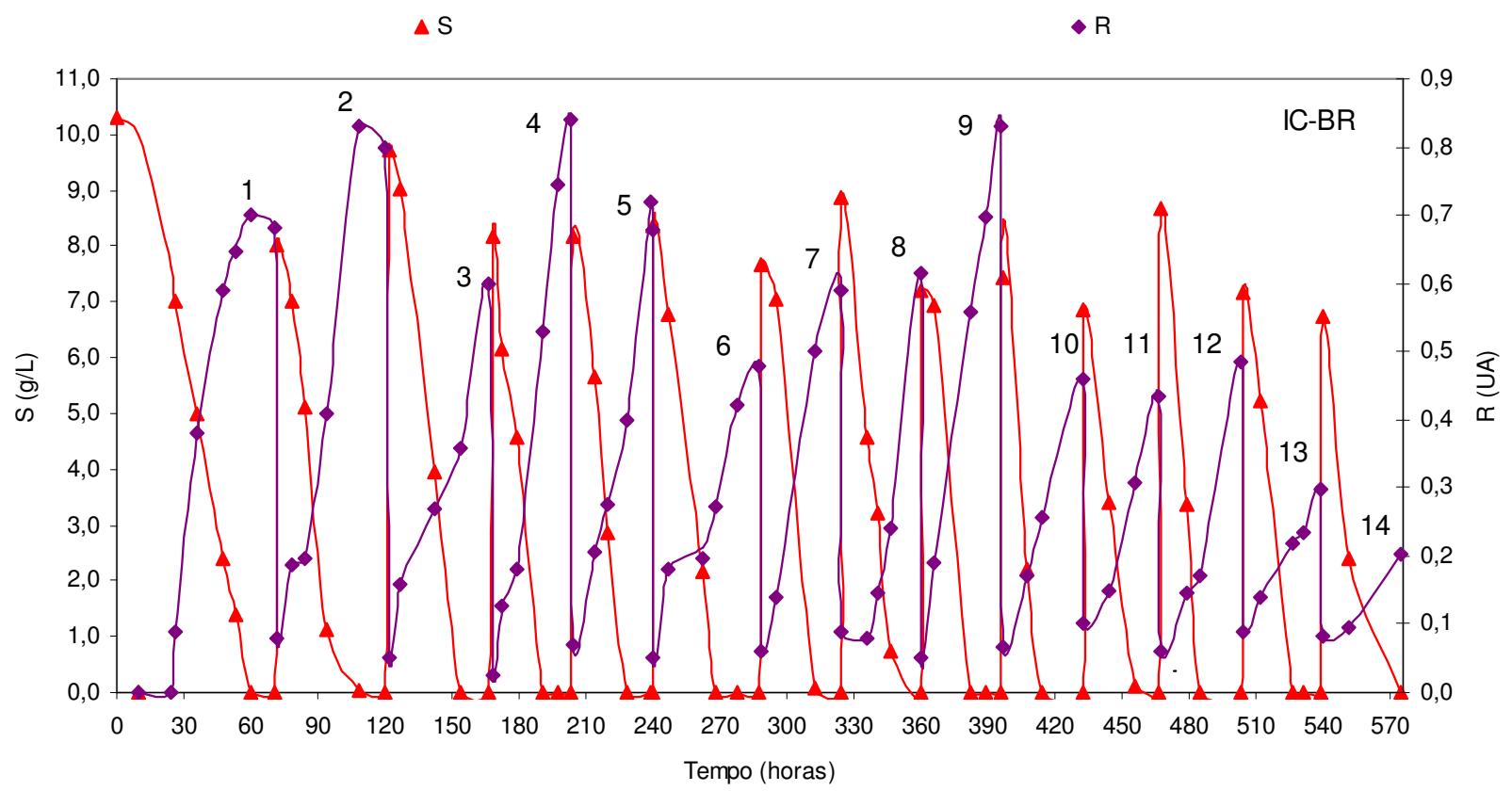

Figura 4.29 - Concentração de glicose residual (S) e produção de retamicina $(R)$ em função do tempo de cultivo no biorreator coluna de bolhas.

Aliando estes resultados aos da figura 4.29, observa-se que a curva de produção de retamicina acompanha a curva de concentração celular livre, o que poderia ser um indicativo de que as células livres fossem responsáveis por essa produção. Porém, resultados anteriores (PAMBOUKIAN, 2003) mostraram claramente que a produção da retamicina ocorre sob baixa velocidade específica de crescimento, portanto, pode-se inferir que a produção de retamicina se deva, em sua maior parte, às células imobilizadas, fato este também observado por Azevedo (2005).

As figuras 4.30 a 4.33 apresentam os pontos experimentais $\left(\mathrm{X}_{\mathrm{I}, \mathrm{Rf}}, \mathrm{X}_{\mathrm{M}, \mathrm{Rf}}, \mathrm{X}_{\mathrm{TF}} \mathrm{e}\right.$ $R_{f}$ ) e os parâmetros calculados ( $Y_{X / S}, Y_{R / S}, P_{X}, P_{R}$ e $\left.R_{\text {esp }}\right)$, obtidos no ensaio ao final de cada batelada (item 3.6.3 - Materiais e Métodos). Também apresentam a linha de tendência relativa a estes pontos, que foi traçada com base nos valores médios das bateladas, quando não foi observada nenhuma tendência definida, seja crescente ou decrescente. 
A partir da Figura 4.30 verifica-se uma oscilação nos valores de $\mathrm{X}_{\mathrm{T}}$ em torno do valor médio de 6,5 $\mathrm{g} / \mathrm{L}$ durante todo o ensaio, e conseqüentemente o fator de conversão de substrato em células (Figura 4.32) apresentou igualmente uma tendência constante, em torno de 0,45 g/g. A produtividade em células (Figura 4.33), da mesma forma, não apresentou nenhuma tendência definida, com valores oscilando em torno de um valor médio de $0,9 \mathrm{~g} / \mathrm{L} . \mathrm{h}$.

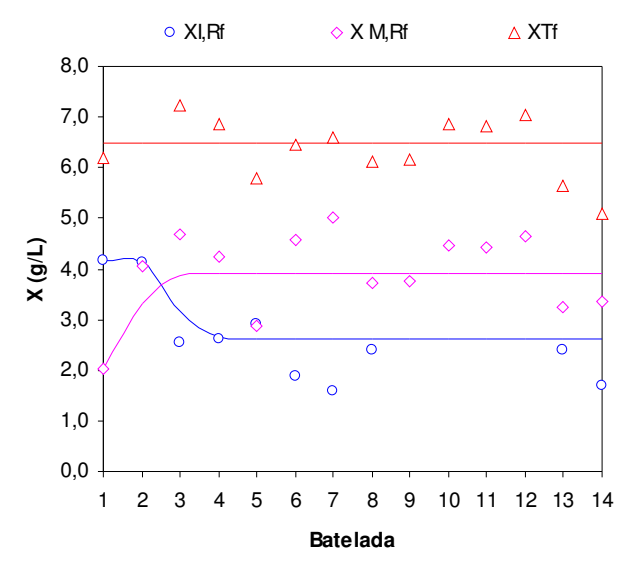

Figura 4.30 - Concentração celular imobilizada $\left(\mathrm{X}_{\mathrm{I}, \mathrm{Rf}}\right)$, livre $\left(\mathrm{X}_{\mathrm{M}, \mathrm{Rf}}\right)$ e total $\left(\mathrm{X}_{\mathrm{Tf}}\right)$ ao final de cada batelada.

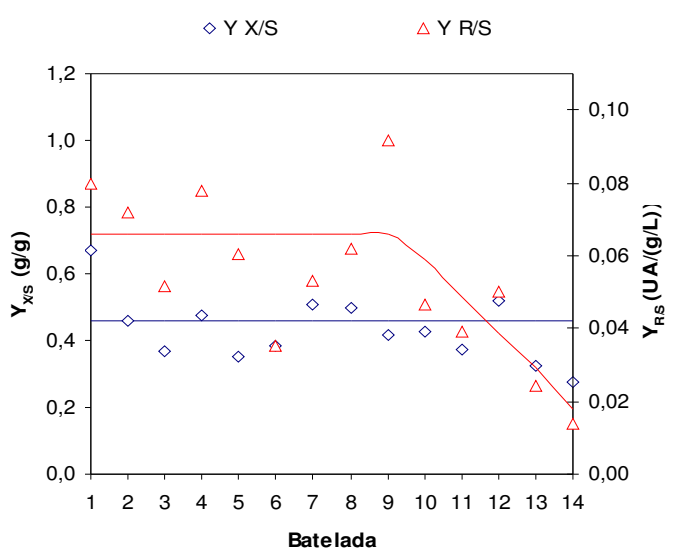

Figura 4.32 - Fator de conversão de substrato em células $\left(\mathrm{Y}_{\mathrm{X} / \mathrm{S}}\right)$ e de substrato em retamicina $\left(\mathrm{Y}_{\mathrm{R} / \mathrm{S}}\right)$

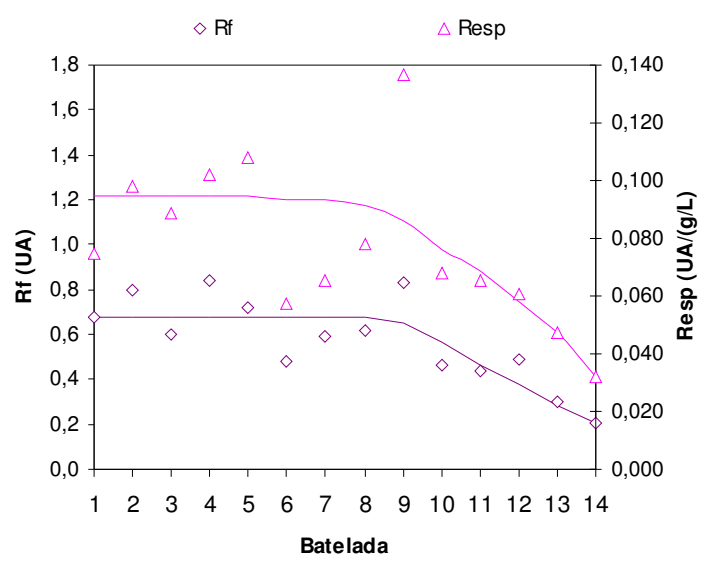

Figura 4.31 - Produção de retamicina (Rf) e produção específica $\left(R_{\text {esp }}\right)$ ao final de cada batelada

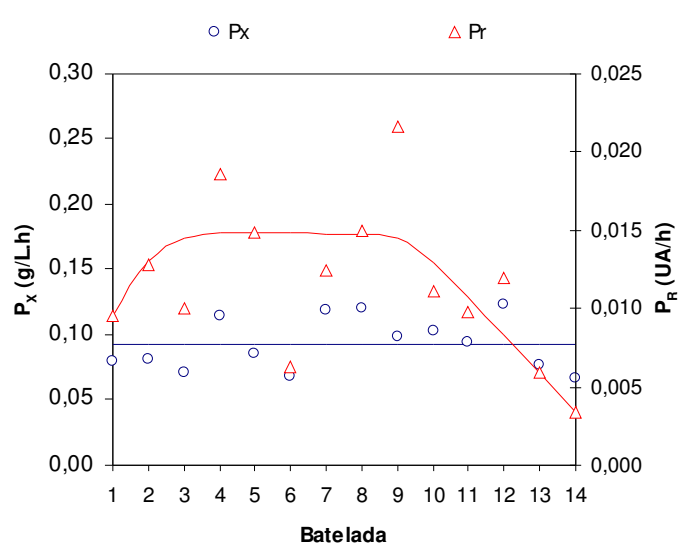

Figura 4.33 - Produtividade em células $\left(\mathrm{P}_{\mathrm{X}}\right)$ e produtividade em retamicina $\left(\mathrm{P}_{\mathrm{R}}\right)$

A produção de retamicina (Figura 4.31) apresentou valores em torno de 0,68 UA até a batelada 9, e depois apresentou tendência decrescente. Isso ocorreu provavelmente devido à diminuição do número de células viáveis ao longo do 
ensaio. Este fato se refletiu nos perfis da produção específica $\left(R_{e s p}\right)$ e no fator de conversão de substrato em retamicina $\left(\mathrm{Y}_{\mathrm{R} / \mathrm{S}}\right)$, Figura 4.31, observando-se a mesma tendência decrescente após esta batelada 9.

Em relação à produtividade em retamicina (Figura 4.33) observou-se um perfil crescente até a batelada 4 devido ao maior tempo de duração das duas primeiras bateladas e à produção constante de retamicina, com valores em torno de 0,015 UA/h da batelada 4 até a batelada 9 , e perfil decrescente a partir desse instante, devido à queda na produção de retamicina.

Alguns trabalhos em reatores fluidizados (SRINIVASULU et al., 2003; SILVA et al., 2003) mostraram que efeitos de limitação difusionais nestes biorreatores afetaram a produção ocorrendo diminuição da produtividade volumétrica ao longo das fermentações em sistemas de bateladas repetidas, assim como foi observado para a retamicina neste ensaio no biorreator coluna de bolhas.

A Figura 4.34 ilustra o aspecto do leito de células imobilizadas no biorreator coluna de bolhas em diferentes instantes do cultivo em bateladas repetidas. Pode-se observar a homogeneidade do meio de cultura durante as bateladas, com o gel sempre bem distribuído por todo o volume do biorreator. Observou-se também a diferença de coloração entre o início da batelada 1, Figura 4.34(a) e o início da batelada 2, Figura 4.34 (d), devido à coloração mais arroxeada, devido a retamicina que permanece no gel após o cultivo e difunde para o meio líquido.

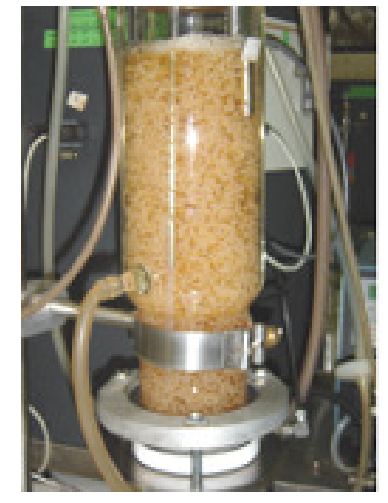

a

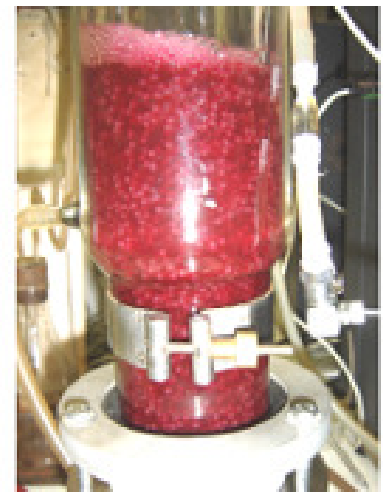

b

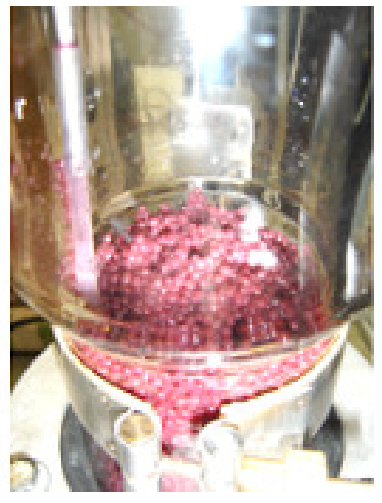

C

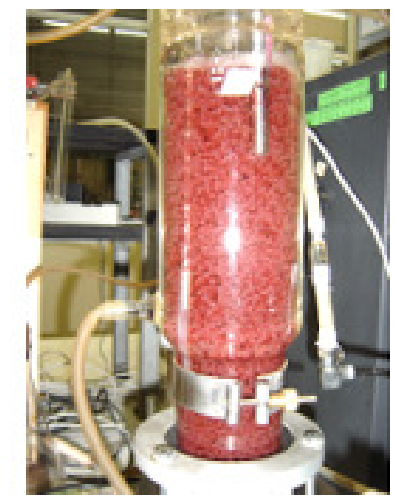

d

Figura 4.34 - Ensaio em bateladas repetidas no biorreator coluna de bolhas no início da primeira batelada (a), final da primeira batelada (b), gel após esgotamento do meio (c) e início da segunda batelada (d). 
A boa integridade física do gel ao longo das primeiras 9 bateladas, pode ser observada pelas ilustrações apresentadas na figura 4.35, a seguir.
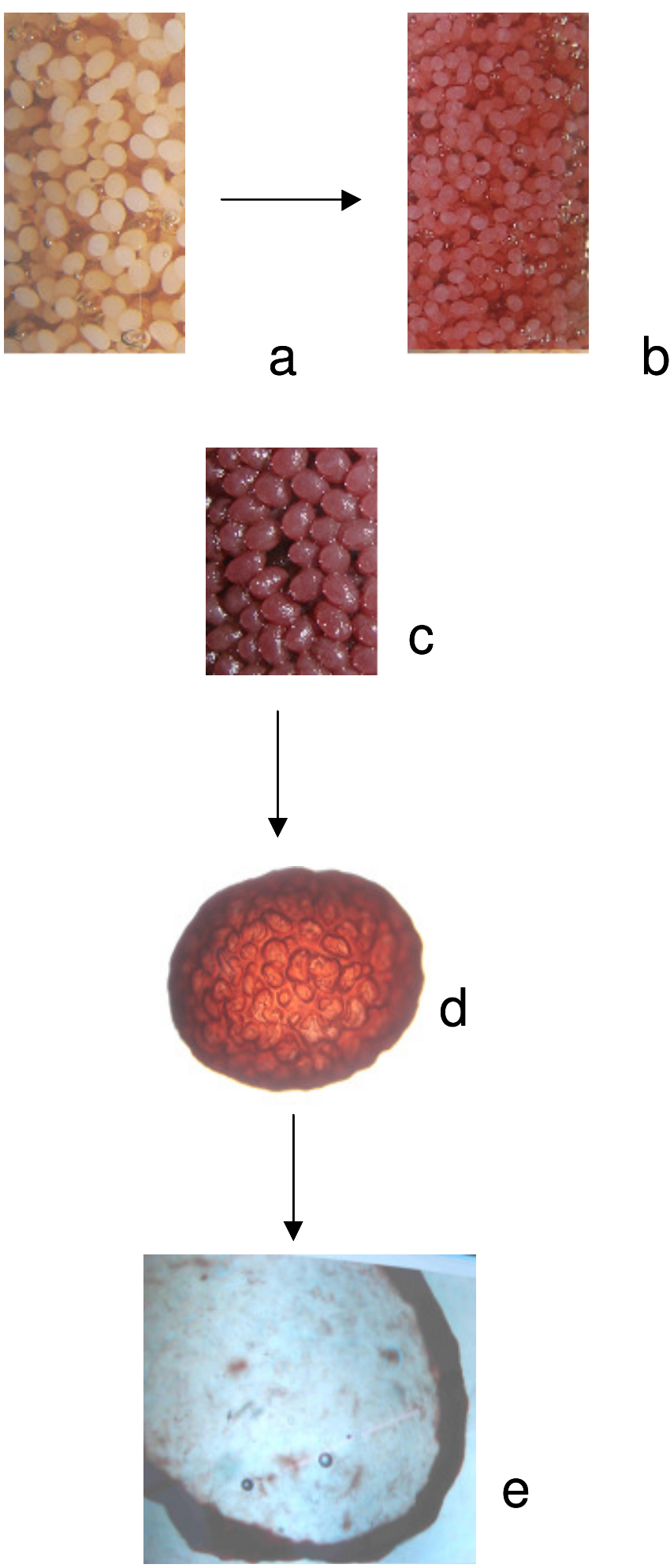

Figura 4.35: Ensaio em bateladas repetidas no biorreator coluna de bolhas: gel no início da batelada 1(a), final da batelada repetida 9 (b) e (c), imagem do gel em microscópio ótico (d) e (e) 


\subsubsection{Ensaio no biorreator coluna de bolhas com células imobilizadas em sistema contínuo.}

A figura 4.36, a seguir, apresenta os resultados do ensaio contínuo no biorreator coluna de bolhas (IC-C1), no qual foram aplicadas as vazões específicas de alimentação de $D=0,05 \mathrm{~h}^{-1}$ e $D=0,015 \mathrm{~h}^{-1}$. Estas vazões foram escolhidas com base nos ensaios contínuos realizados em biorreator cesta, conforme apresentado no item 4.1.3.1 e 4.1.3.2, a partir dos quais se pôde observar que a melhor condição para produção da retamicina foi a aplicação de $D=0,05 \mathrm{~h}^{-1}$, iniciando a alimentação apenas quando a concentração de glicose estivesse próxima de se esgotar. Alguns trabalhos da literatura mostram que vazões específicas de alimentação na faixa de 0,015 e $0,020 \mathrm{~h}^{-1}$ foram aplicadas para a produção de metabólitos secundários com células imobilizadas (SRINIVASULU et al., 2003; ADINARAYANA et al., 2004; LAVARDA, 2003).

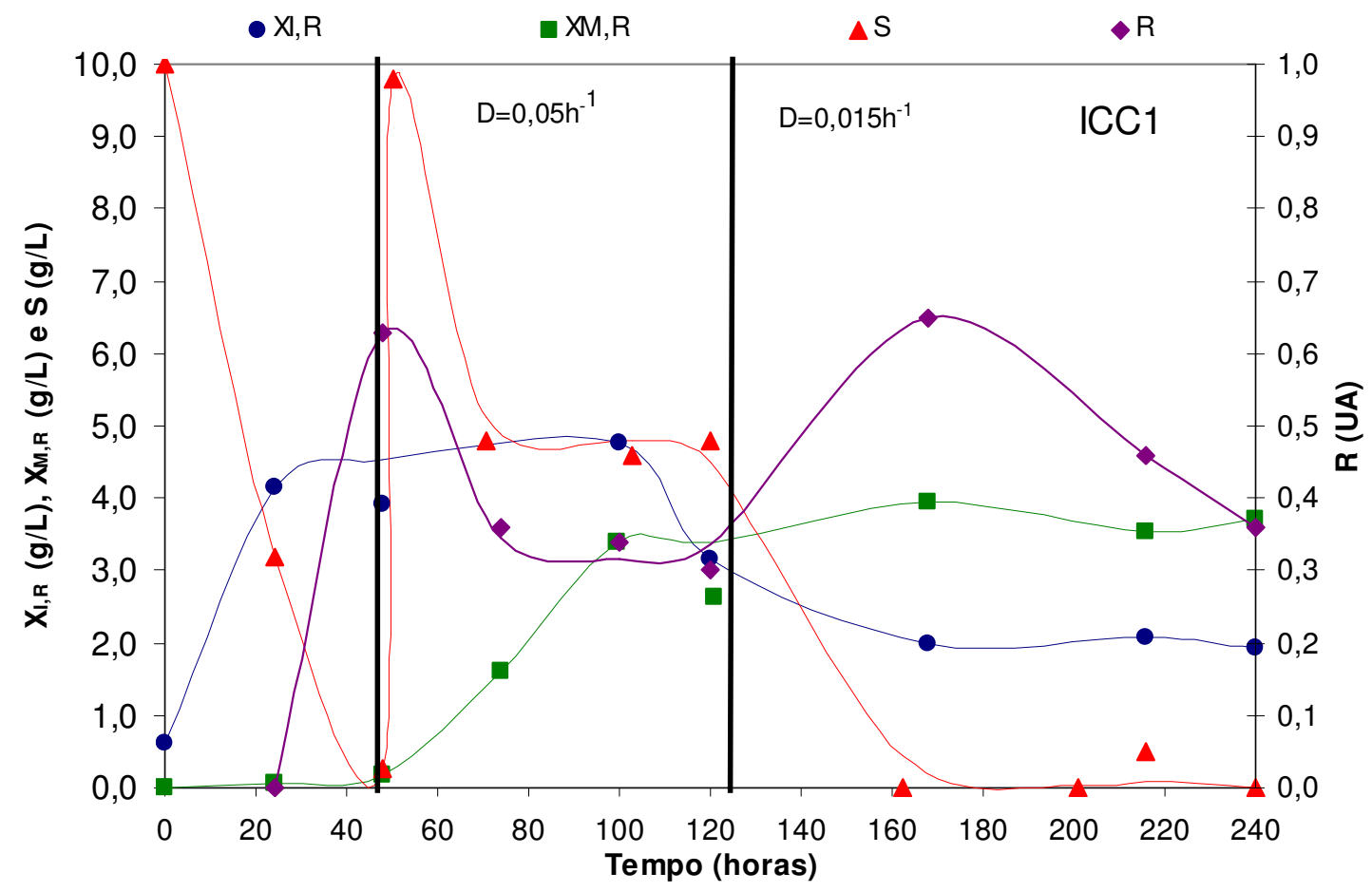

Figura 4.36 - Concentração celular no meio de cultivo $\left(X_{M, R}\right)$ e imobilizada $\left(X_{1, R}\right)$, concentração de glicose residual $(S)$ e produção da retamicina $(R)$ no ensaio com células imobilizadas no biorreator coluna de bolhas em sistema contínuo com vazão específica de alimentação de 0,05 e $0,015 \mathrm{~h}^{-1}($ IC-C1). 
O início da alimentação ocorreu após uma fase descontínua de 48 horas de cultivo, tempo este no qual a concentração celular imobilizada tinha atingido cerca de $4 \mathrm{~g} / \mathrm{L}$, a concentração de glicose havia se esgotado e a produção de retamicina já se encontrava em torno de 0,65 UA, valor este próximo ao máximo atingido no ensaio IC2 (cerca de 0,8 UA). O início da alimentação com $D=0,05 \mathrm{~h}^{-1}$ ocasionou um acúmulo de glicose no meio, estabilizando-se em torno de $5 \mathrm{~g} / \mathrm{L}$. A concentração celular imobilizada $\left(X_{1, R}\right)$ manteve-se constante, decaindo a partir de 100 horas de cultivo, instante este no qual a concentração de células livres aumentou significativamente atingindo cerca de $3,0 \mathrm{~g} / \mathrm{L}$. Esta condição com $D=0,05 \mathrm{~h}^{-1}$ não foi favorável para a produção de retamicina, a qual estabilizou-se em torno de 0,4 UA, depois de decorridos aproximadamente três tempos de residência (60 horas). Assim deu-se início à segunda condição deste ensaio, que foi a aplicação de $D=0,015 h^{-1}$ (a partir de 120 horas de cultivo).

A segunda condição do ensaio IC-C1 pareceu inicialmente favorecer a produção da retamicina, já que esta aumentou de 0,4 para 0,65 UA nas primeiras 20 horas de alimentação (de 120 a 140 horas de cultivo), porém seu valor voltou a decrescer, o que parece ter ocorrido devido à escassez de glicose a partir de 160 horas de cultivo. Dessa forma, as condições empregadas neste ensaio não conduziram à obtenção de alta produção de retamicina. O consumo total da glicose nesta segunda condição $\left(D=0,015 h^{-1}\right)$ deve ter ocorrido devido à significativa concentração de células livres (3,5 g/L).

Tendo em vista estes resultados, decidiu-se realizar um segundo ensaio contínuo no biorreator coluna de bolhas utilizando uma vazão específica de alimentação intermediária $\left(D=0,03 \mathrm{~h}^{-1}\right)$, de forma que a glicose não se esgotasse completamente, não afetando então a produção da retamicina, como parece ter ocorrido neste ensaio.

A figura 4.37 a seguir apresenta os resultados obtidos para o ensaio IC-C2, o qual foi operado sob vazão específica de alimentação de $D=0,03 \mathrm{~h}^{-1}$, após uma fase descontínua inicial de 48 horas.

Pode-se observar através da Figura 4.37, que o início da fase contínua ainda apresentava uma concentração de glicose em torno de $2 \mathrm{~g} / \mathrm{L}$, a produção da retamicina tinha atingido cerca de 0,83 UA, a concentração de células imobilizadas encontrava-se em torno de 4,8 $\mathrm{g} / \mathrm{L}$ e a concentração de células livres no meio de cultivo atingia cerca de $1 \mathrm{~g} / \mathrm{L}$. Após o início da alimentação verificou-se rapidamente 
a estabilização do sistema, mantendo-se os valores observados no final da fase descontínua até cerca de 3 tempos de residência (96 horas de alimentação), com exceção da concentração celular livre que se estabilizou apenas após 48 horas do início da alimentação, em torno de $3 \mathrm{~g} / \mathrm{L}$. Estes resultados vieram confirmar a expectativa de que esta vazão fosse a mais adequada para o sistema contínuo no biorreator coluna de bolhas com as células imobilizadas, tendo em vista os resultados apresentados anteriormente no ensaio IC-C1. Verificou-se ainda neste ensaio que, diferentemente do ensaio IC-C1, a concentração celular imobilizada permaneceu estável, não decaindo ao longo do tempo, fator este que pode ter contribuído para a estabilidade da produção durante toda fase contínua.

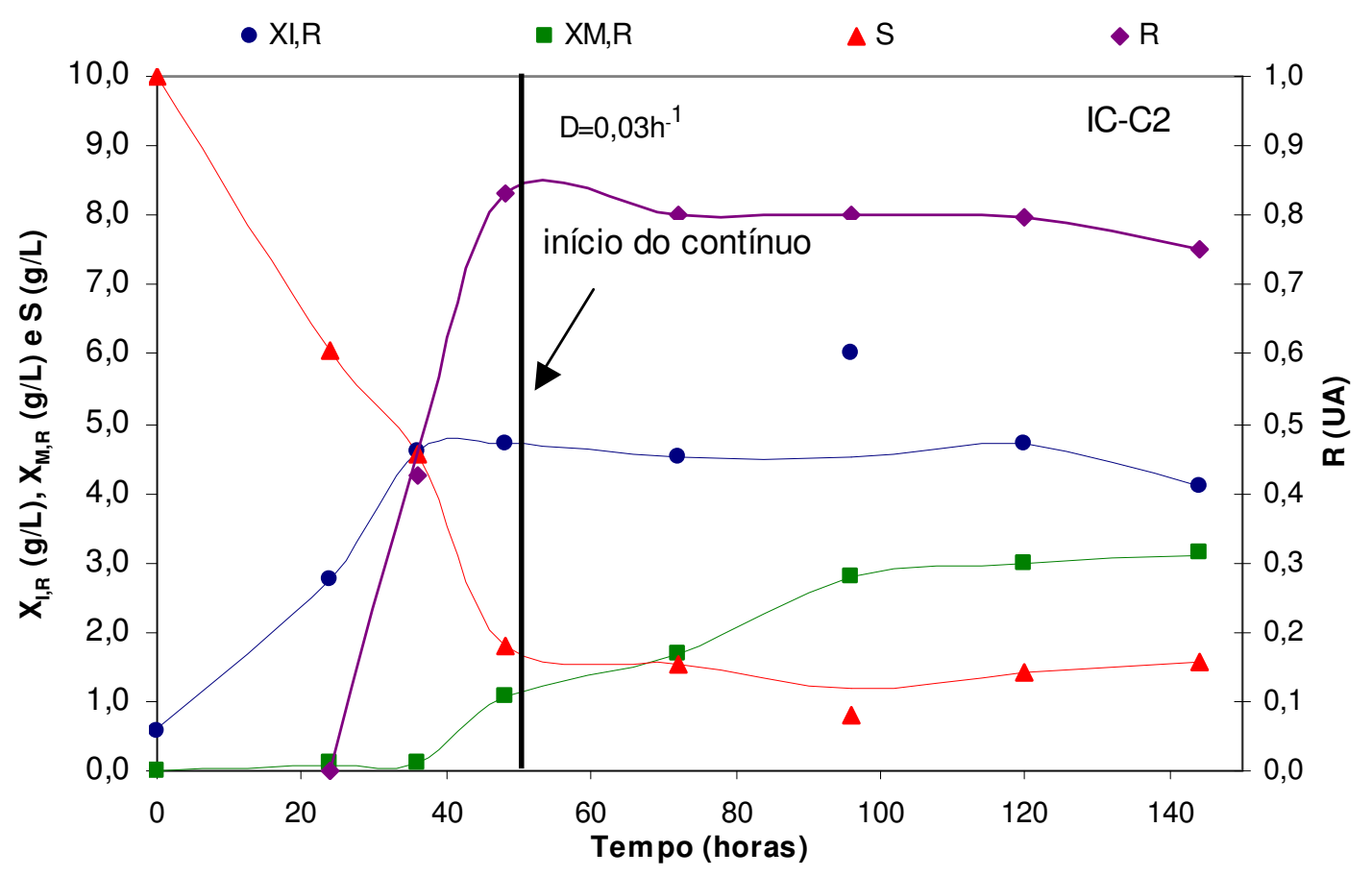

Figura 4.37 - Concentração celular no meio de cultivo $\left(X_{M, R}\right)$ e imobilizada $\left(X_{I, R}\right)$, concentração de glicose residual $(S)$ e produção da retamicina $(R)$ no ensaio com células imobilizadas no biorreator coluna de bolhas em sistema contínuo com vazão específica de alimentação de $0,03 \mathrm{~h}^{-1}$ (IC-C2).

A tabela 4.4, a seguir, apresenta os parâmetros calculados para as três condições de vazão de alimentação nos ensaios IC-C1 e IC-C2, de acordo com as equações apresentadas no item 3.6.3 (Materiais e Métodos). Apesar de não ter sido bem caracterizada uma condição de estado estacionário no ensaio IC-C1 para a 
vazão de $D=0,05 \mathrm{~h}^{-1}$, os parâmetros foram calculados com base nos valores do final do ensaio (240 horas de cultivo).

Tendo em vista os melhores valores de produção de retamicina $(0,8 \cup A)$ para o ensaio IC-C2, com $D=0,03 \mathrm{~h}^{-1}$, também foram observados os maiores valores de produtividade em retamicina $(0,024 \mathrm{UA} / \mathrm{h})$ e produção específica em retamicina $(0,107 \mathrm{UA} /(\mathrm{g} / \mathrm{L}))$. Os valores de $\mu_{\mathrm{x}}$ e $\mu_{\mathrm{s}}$, no ensaio IC-C2, apresentaram valores intermediários, em concordância com o valor de $\mathrm{D}$ intermediário, porém apresentou mesmo valor de $\mu_{R}$ observado para o $D=0,05 \mathrm{~h}^{-1}$.

Tabela 4.4 - Parâmetros obtidos para os ensaios contínuos IC-C1 e IC-C2 no biorreator coluna de bolhas com células imobilizadas

\begin{tabular}{|c|c|c|c|}
\hline & $\mathbf{D = 0 , 0 5 \mathbf { h } ^ { - 1 }}$ & $\mathbf{D}=\mathbf{0 , 0 1 5 \mathbf { h } ^ { - 1 }}$ & $\mathbf{D}=\mathbf{0 , 0 3 \mathbf { h } ^ { - 1 }}$ \\
\hline $\mathrm{X}_{\mathrm{Te}}(\mathrm{g} / \mathrm{L})$ & 4,8 & 4,6 & 7,45 \\
\hline $\mathrm{S}_{\mathrm{a}}(\mathrm{g} / \mathrm{L})$ & 10,0 & 10,0 & 10,0 \\
\hline $\mathrm{S}_{\mathrm{e}}(\mathrm{g} / \mathrm{L})$ & 4,8 & 0,0 & 1,5 \\
\hline $\mathrm{R}_{\mathrm{e}}(\mathrm{g} / \mathrm{L})$ & 0,30 & 0,40 & 0,80 \\
\hline$\mu_{X}\left(\mathrm{~h}^{-1}\right)$ & 0,050 & 0,015 & 0,030 \\
\hline$\mu_{\mathrm{S}}(\mathrm{g} / \mathrm{gh})$ & 0,045 & 0,026 & 0,034 \\
\hline$\mu_{R}(\mathrm{UA} /(\mathrm{g} / \mathrm{L}) \cdot \mathrm{h}$ & 0,003 & 0,001 & 0,003 \\
\hline $\mathrm{Y}_{\mathrm{X} / \mathrm{S}}(\mathrm{g} / \mathrm{g})$ & 1,074 & 0,560 & 0,876 \\
\hline $\mathrm{Y}_{\mathrm{R} / \mathrm{S}}(\mathrm{UA} /(\mathrm{g} / \mathrm{L})$ & 0,056 & 0,040 & 0,094 \\
\hline $\mathrm{P}_{X}(\mathrm{~g} / \mathrm{L} \cdot \mathrm{h})$ & 0,290 & 0,084 & 0,224 \\
\hline $\mathrm{P}_{\mathrm{R}}(\mathrm{UA} / \mathrm{h})$ & 0,015 & 0,006 & 0,024 \\
\hline$R_{\text {esp }}(\mathrm{UA} /(\mathrm{g} / \mathrm{L}))$ & 0,052 & 0,071 & 0,107 \\
\hline
\end{tabular}

A comparação destes resultados aos obtidos por Pamboukian et al. (2004) em cultivo contínuo com células livres de $S$. olindensis, em biorreator STR, permitem observar que a condição de $D=0,03 \mathrm{~h}^{-1}$ apresentou valores equivalentes tanto de produção (em torno de 0,8 $\mathrm{UA}$ ), quanto de produtividade em retamicina (em torno de 0,025 UA/h), porém, Pamboukian et al. (2004) observaram maiores valores de produção (em torno de 1,2 UA) e produtividade em retamicina (em torno de 0,06 $U A / h)$ para a condição de $D=0,05 h^{-1}$. 


\subsection{Comparação entre os ensaios em biorreatores cesta e coluna de bolhas}

Para se realizar uma comparação entre os diferentes sistemas e reatores empregados no presente trabalho, alguns ensaios foram agrupados de acordo com o sistema empregado: batelada simples com células imobilizadas, batelada simples com células livres e, por último, uma comparação dos ensaios com células imobilizadas em sistema contínuo e de bateladas repetidas.

\subsubsection{Comparação entre os ensaios em batelada simples}

A Figura 4.38 apresenta a comparação do ensaio com células imobilizadas no biorreator coluna de bolhas (IC1) e no biorreator cesta (SI-500), ambos realizados com 1 vvm de aeração.

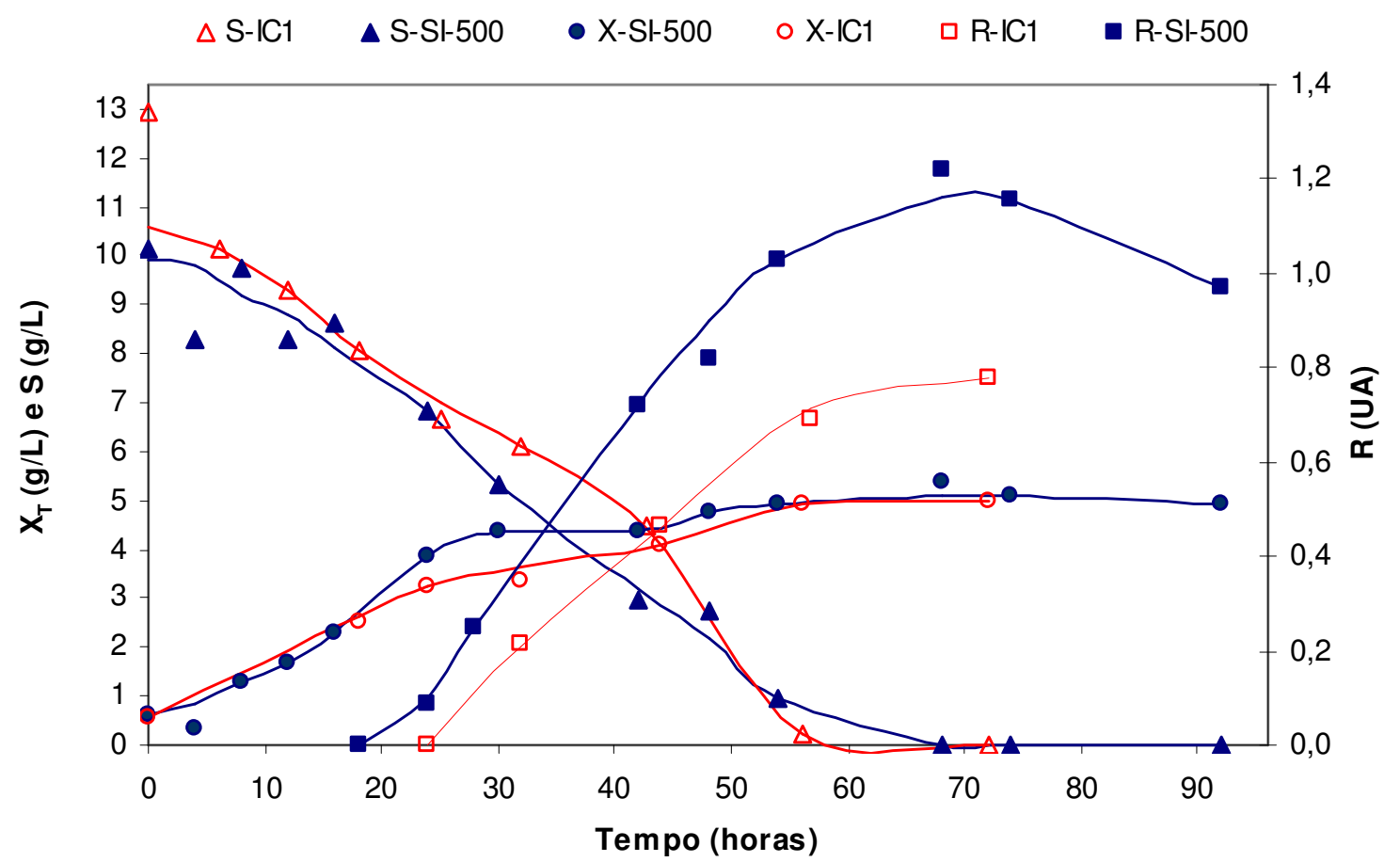

Figura 4.38 - Concentração celular total $\left(\mathrm{X}_{T}\right)$, concentração de glicose residual $(\mathrm{S})$ e produção da retamicina $(R)$ nos ensaios com células imobilizadas no biorreator coluna de bolhas (IC1) e cesta (SI-500). 
A partir da Figura 4.38, observa-se que as cinéticas de crescimento celular e consumo de glicose foram similares, apresentando uma diferença significativa apenas para a produção da retamicina, a qual foi maior no biorreator cesta no ensaio SI-500 (1,2 UA em 70 horas) em comparação ao ensaio IC1 no biorreator coluna de bolhas (0,8 UA em 72 horas). Esta diferença deve-se principalmente às limitações difusionais, que tiveram menor intensidade devido às condições de agitação e aeração do biorreator cesta, tendo em vista que mesmo aplicando maiores vazões de aeração (2 e 3 vvm) no biorreator coluna de bolhas, a produção da retamicina não atingiu valores próximos do ensaio SI-500, conforme já discutido no item 4.2.1.

A Figura 4.39 apresenta a comparação dos ensaios com células livres no biorreator coluna de bolhas (LC1) e no biorreator cesta (SL-500), ambos realizados com 1 vvm de aeração.

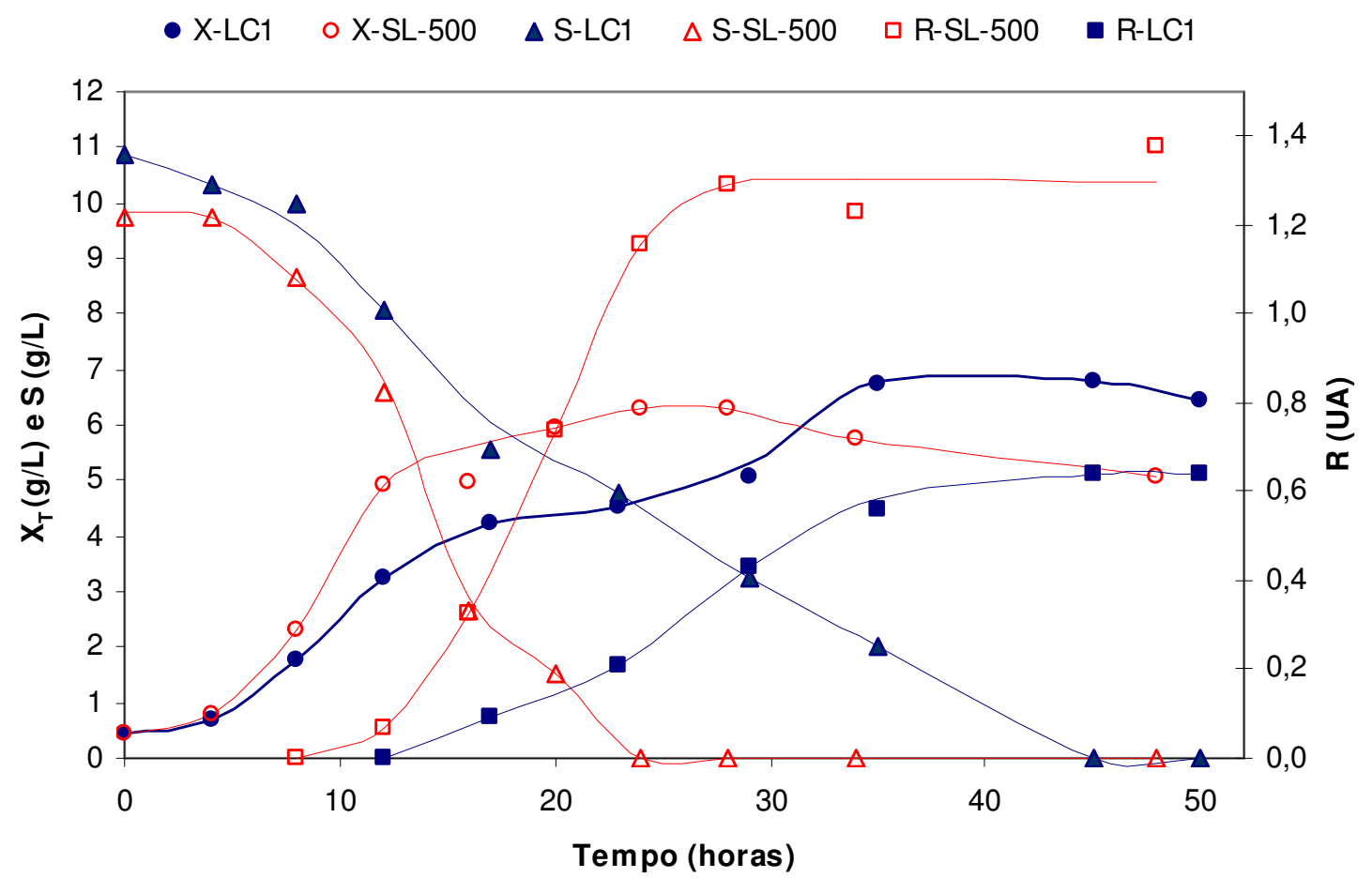

Figura 4.39 - Concentração celular total $\left(X_{T}\right)$, concentração de glicose residual $(S)$ e produção da retamicina $(\mathrm{R})$ nos ensaios com células livres no biorreator cesta (SL-500) e no biorreator coluna de bolhas (LC1).

Observa-se que o ensaio LC1 apresentou cinéticas mais lentas em relação ao ensaio SL-500, assim como valores menores de produção da retamicina. O menor desempenho do ensaio LC1 pode, possivelmente, ser explicado tanto pela baixa 
concentração de oxigênio dissolvido observado a partir de 12 horas de cultivo (Figura 4.23), tendo-se atingido cerca de 10\% da saturação, nível este considerado limitante para processos aeróbios e, portanto, para a produção de retamicina também, conforme já discutido anteriormente no item 4.2.2. Outro fator importante a ser considerado é a morfologia apresentada nos cultivos, pois, conforme foi observado por Pamboukian (2003) em cultivo realizado nas mesmas condições do ensaio SL-500, a produção de retamicina foi favorecida para condições que apresentaram morfologia predominantemente na forma de clumps (diâmetros na faixa de 100 a $200 \mu \mathrm{m}$ ) e hifas livres. Provavelmente, os pellets formados no ensaio no biorreator coluna de bolhas (LC1) tinham dimensões bem maiores em relação ao ensaio SL-500, devido ao menor cisalhamento das células pela ausência de agitação mecânica, condição esta que se mostrou desfavorável à produção da retamicina.

A tabela 4.5 apresenta um resumo de todos os parâmetros obtidos com células livres e imobilizadas em biorreatores cesta e coluna de bolhas, sob vazão de aeração de 1 vvm, em ensaios em batelada simples.

Tabela 4.5 - Resumo dos resultados obtidos nos ensaios SL-500, SI-500, LC1, IC1

\begin{tabular}{|c|c|c|c|c|}
\hline & \multicolumn{4}{|c|}{ Ensaio } \\
\cline { 2 - 5 } & SL-500 & SI-500 & LC1 & IC1 \\
\hline $\mathrm{X}_{\mathrm{T} 0}$ & 0,47 & 0,42 & 0,46 & 0,6 \\
\hline $\mathrm{X}_{\mathrm{Tm}}(\mathrm{g} / \mathrm{L})$ & 6,3 & 5,0 & 6,75 & 4,96 \\
\hline $\mathrm{t}_{\mathrm{m}}$ & 24 & 42 & 35 & 56 \\
\hline $\mathrm{R}_{\mathrm{m}}(\mathrm{UA})$ & 1,3 & 1,2 & 0,64 & 0,78 \\
\hline $\mathrm{t}_{\mathrm{m}}$ & 28 & 68 & 45 & 72 \\
\hline$\mu_{\max }$ & 0,21 & 0,20 & 0,171 & 0,098 \\
\hline $\mathrm{S}_{0}(\mathrm{~g} / \mathrm{L})$ & 9,74 & 9,20 & 10,80 & 11,00 \\
\hline $\mathrm{Y}_{\mathrm{X} / \mathrm{S}}(\mathrm{g} / \mathrm{g})$ & 0,60 & 0,61 & 0,58 & 0,40 \\
\hline $\mathrm{Y}_{\mathrm{R} / \mathrm{S}}(\mathrm{UA} /(\mathrm{g} / \mathrm{L}))$ & 0,130 & 0,130 & 0,059 & 0,071 \\
\hline $\mathrm{P}_{\mathrm{X}}(\mathrm{g} / \mathrm{L} . \mathrm{h})$ & 0,240 & 0,100 & 0,180 & 0,078 \\
\hline $\mathrm{P}_{\mathrm{R}}(\mathrm{UA} / \mathrm{h})$ & 0,046 & 0,018 & 0,014 & 0,011 \\
\hline$R_{\text {esp }}(\mathrm{UA} /(\mathrm{g} / \mathrm{L}))$ & 0,206 & 0,245 & 0,102 & 0,179 \\
\hline
\end{tabular}

${ }^{*} t_{\mathrm{m}}$ : instante de máxima concentração celular

${ }^{* *} t_{m}$ ': instante de máxima absorbância 
De acordo com a tabela 4.5, pode-se observar que os melhores resultados com ensaios em bateladas simples, em termos de produtividade em células e retamicina, foram alcançados para o ensaio SL-500, com células livres, no biorreator cesta $(0,24 \mathrm{~g} / \mathrm{L}$.h e $0,046 \mathrm{UA} / \mathrm{h}$, respectivamente). Já em relação à produção específica da retamicina $\left(R_{\text {esp }}\right)$, os melhores resultados foram obtidos para os ensaios com células imobilizadas nos biorreatores cesta e coluna de bolhas $(0,245 \mathrm{e}$ $0,179 \mathrm{UA} /(\mathrm{g} / \mathrm{L})$ ), respectivamente, indicando mais uma vez uma aparente mudança no metabolismo, de forma a favorecer a produção específica da retamicina.

Em concordância com estes resultados, os trabalhos de Mahmoud et al. (1987) e Adinarayana et al. (2002) observaram maiores produtividades em sistema com células livres, porém foram obtidas maiores produções específicas em sistema com células imobilizadas.

Apesar do ensaio SI-500, com células imobilizadas, apresentar uma maior produção específica, o ensaio com células livres, SL-500, foi o que apresentou melhor desempenho entre os ensaios em batelada simples, por apresentar conjuntamente maior produção e maior produtividade em retamicina.

\subsubsection{Comparação dos sistemas com células imobilizadas em sistema contínuo e de bateladas repetidas}

A tabela 4.6 apresenta valores médios de concentração celular total $\left(\mathrm{X}_{\mathrm{TF}}\right)$, produtividade em células $\left(P_{x}\right)$, produção de retamicina $\left(R_{F}\right)$ e produtividade em retamicina $\left(P_{R}\right)$ ao final das bateladas repetidas com células imobilizadas nos ensaios em biorreator cesta (ensaio SI-BR1) e coluna de bolhas (ensaios IC-BR), calculados a partir dos valores apresentados na tabela 4.2 e nas Figuras 4.30, 4.32 e 4.33. Incluiu-se também na Tabela 4.6 os valores obtidos em estado estacionário no ensaio contínuo IC-C2, com $D=0,03 \mathrm{~h}^{-1}$. 
Tabela 4.6 - Comparação da produção de retamicina em sistema contínuo e de bateladas repetidas com células imobilizadas.

\begin{tabular}{cccccc}
\hline Biorreator & $\begin{array}{c}\text { Número de } \\
\text { bateladas }\end{array}$ & $\begin{array}{c}\mathbf{X}_{\mathrm{TF}} \text { ou } \mathbf{X}_{\mathrm{Te}} \\
(\mathrm{g} / \mathrm{L})\end{array}$ & $\begin{array}{c}\mathbf{P}_{\mathbf{x}} \\
(\mathrm{g} / \mathrm{L} . \mathrm{h})\end{array}$ & $\begin{array}{c}\mathbf{R}_{\mathrm{F}} \text { ou } \mathbf{R}_{\mathbf{e}} \\
(\mathrm{UA})\end{array}$ & $\begin{array}{c}\mathbf{P}_{\mathbf{R}} \\
(\mathrm{UA} / \mathrm{h})\end{array}$ \\
\hline Cesta $^{\mathrm{a}}$ (SI-BR1) & 3 & 6,0 & 0,058 & 1,72 & 0,031 \\
Coluna de bolhas $^{\mathrm{b}}$ (IC-BR) & 9 & 6,5 & 0,170 & 0,70 & 0,015 \\
Coluna de bolhas (IC-C2) & contínuo & 7,5 & 0,224 & 0,80 & 0,024 \\
\hline${ }^{\mathrm{a}}$ média do valor final das bateladas 2-9 & & & & \\
${ }^{\mathrm{b}}$ média do valor final das bateladas 2-3 & & & &
\end{tabular}

A comparação dos processos em bateladas repetidas, nos dois tipos de biorreatores, mostra claramente que o sistema com células imobilizadas no biorreator coluna de bolhas favoreceu uma maior produtividade em células, enquanto que os valores obtidos no reator cesta mostraram que este apresenta melhor desempenho para a produção da retamicina, porém a realização de um processo operado com um número grande de bateladas foi possível apenas no reator coluna de bolhas, indicando que a sua utilização pode ser vantajosa, desde que sejam efetuados novos estudos para aumentar a produção da retamicina neste sistema.

Comparando-se os resultados obtidos no biorreator coluna de bolhas, em sistema contínuo com $\mathrm{D}=0,03 \mathrm{~h}^{-1}$ (IC-C2) e em bateladas repetidas (IC-BR), verifica-se que a produção de retamicina apresentou valores similares (0,8 e 0,7 UA, respectivamente), enquanto que foi obtida maior produtividade em retamicina no ensaio IC-C2 em relação ao ensaio IC-BR (0,024 e 0,015 /UA/h, respectivamente).

No entanto, ainda no que se refere à produção de retamicina, observa-se que o valor da produção obtida no ensaio SI-BR1 (1,7 UA) foi cerca de 2,2 vezes maior ao obtido no ensaio IC-C2, e conseqüentemente, também foi obtida a maior produtividade $(0,031 \mathrm{UA} / \mathrm{h})$ no biorreator cesta.

Estes resultados indicam que as maiores concentrações e produtividades em retamicina foram alcançados em bateladas repetidas no biorreator cesta, porém tendo em vista as dificuldades operacionais encontradas para este sistema, pode-se indicar a utilização do biorreator coluna de bolhas em sistema contínuo, sob vazão específica de alimentação de $0,03 \mathrm{~h}^{-1}$, como a melhor condição para a produção da retamicina com células imobilizadas. 
Ainda com relação a estas comparações, a obtenção de uma maior produção da retamicina poderá ser investigada a partir de estudos em outros suportes, que propiciem um maior difusão intraparticular e menor liberação de células para o meio líquido, assim como a operação do biorreator coluna de bolhas empregando-se outros tipos de aspersores, ou ainda, utilizar o biorreator tipo airlift, de forma a melhorar as condições de transferência de massa nestes sistemas. 


\section{CONCLUSÕES}

Os resultados obtidos no presente trabalho permitiram obter as seguintes conclusões gerais:

- As comparações entre os ensaios com células livres e imobilizadas nos biorreatores cesta e coluna de bolhas, mostraram que os efeitos de limitações difusionais de nutrientes e oxigênio afetaram significativamente as cinéticas do processo com células imobilizadas e, conseqüentemente, foram obtidas menores produtividades em células e em produto. Portanto, considerando-se apenas uma batelada, a condição mais vantajosa para produção da retamicina foi o sistema com células livres no biorreator STR.

- Dentre as condições estudadas no biorreator cesta, a condição mais favorável para a produção da retamicina foi a operação com freqüência de agitação de $500 \mathrm{rpm}$ e $1 \mathrm{vvm}$, em sistema de bateladas repetidas, para as quais foi obtida produção em torno de 1,5 a 1,7 UA (bateladas 2 e 3). Porém não foi possível prolongar o ensaio realizando um número maior que 3 bateladas, devido aos problemas operacionais (adesão e crescimento das células livres sobre a cesta).

- Os resultados nos ensaios contínuos no biorreator cesta não foram satisfatórios, pois observou-se o mesmo problema de adesão e crescimento de células livres sobre a cesta apresentado nas bateladas repetidas;

- O sistema com células imobilizadas em bateladas repetidas no biorreator coluna de bolhas pôde ser operado por um número maior de bateladas repetidas ( 9 bateladas) em relação aos ensaios no biorreator cesta ( 3 batelada), porém foram obtidos menores valores médios de produção da retamicina $(0,7 \mathrm{UA})$ durante as nove bateladas. Portanto, este sistema pode apresentar-se mais vantajoso em relação ao biorreator cesta, desde que sejam efetuados novos estudos para aumentar a produção da retamicina no biorreator coluna de bolhas. 
- A operação do sistema contínuo no biorreator coluna de bolhas, em diferentes vazões específicas de alimentação, mostrou que a aplicação de $D=0,03$ $\mathrm{h}^{-1}$ foi a vazão específica mais adequada para produção da retamicina, tendo em vista que foram obtidos maiores valores de produção $(0,8 \cup A)$ e produtividades em retamicina $(0,024 \mathrm{UA} / \mathrm{h})$;

- Considerando-se todas as condições estudadas nos biorreatores cesta e coluna de bolhas, pode-se indicar o processo contínuo com células imobilizadas no biorreator coluna de bolhas, como a condição mais promissora para uma futura produção da retamicina em larga escala, considerando-se que dentre as vantagens da imobilização destacam-se o uso prolongado das células e a obtenção de caldos com baixas concentrações de células livres, o que facilita as operações de recuperação e purificação do produto.

- O suporte utilizado para a imobilização de S. olindensis, o gel de alginato de cálcio, apresentou boa estabilidade mecânica para os processos de longa duração (sistemas de bateladas repetidas e contínuos), porém observou-se um significativo desprendimento das células, após o crescimento no interior do gel, resultando em um cultivo misto de células livres e imobilizadas, e não estritamente de células imobilizadas.

- Como continuidade deste trabalho sugere-se, então, novos estudos relacionados à utilização de outros suportes para a imobilização de $S$. olindensis, assim como a aplicação de outras configurações de biorreatores, partindo-se das melhores condições de cultivos apresentadas neste trabalho para a produção da retamicina. 


\section{REFERÊNCIAS BIBLIOGRÁFICAS}

ABELYAN, V. A.; ABELYAN, L .A. Production of lactic acid by immobilized cells in stirred reactors. Applied Biochemistry and Microbiology, New York, v. 32, n. 5, p. 495-499, 1996.

ADINARAYANA, K.; SRINIVASULU, B.; BAPI RAJU, K. V. V. S. N.; ELLAIAH, P. Continuous neomycin production by immobilized cells of Streptomyces marinensis NUV-5 in an airlift bioreactor. Process Biochemistry, Oxford, v. 39, n. 11, p. 14071414. July. 2004.

AlMEIDA, V. L. LeitÃO, A. REINA, L. C. B.; MONTANARI, C. A. DONICCI, C. L. Câncer e agentes antineoplásicos ciclo-celular específicos e ciclo-celular não específicos que interagem com o dna: uma introdução. Química Nova Brasil, v. 1, p. 118-129, 2005.

ALMEIDA, R. M. R. G.; CRUZ, A. J. G. ; ARAUJO, M. L. G. C. ; GIORDANO, R. C. ; HOKKA, C. O. Comparação do processo de produção de cefalosporina $C$ em biorreator tipo torre em batelada e em batelada alimentada. In: XXVII Congresso Brasileiro De Sistemas Particulados (ENEMP'99), Campos do Jordão - SP.. São Paulo - SP : EPUSP, 1999. v. prelo.

AMSDEN, B.; TUNER, N. Diffusion characteristics of calcium alginate gels. Biotechnology and Bioengineering, New York, v. 65, n. 5, p. 605-610, Dec. 1999.

ARGIRIOU, T.; KANELLAKI, M.; VOLIOTIS, S.; KOUTINAS, A. A. Kissiris-supported yeast cells: high biocatalytic stability and productivity improvement by successive preservations at $0^{\circ} \mathrm{C}$. Journal of Agricultural and Food Chemistry, Easton, v. 44 n. 12, p. 4028-4031. Dec. 1996.

AUGUSTO, E. F. P.; OLIVEIRA, M. S. Processos com células animais. In: LIMA, U. A., AQUARONE, E.; BORZANI, W., SCHMIDELL NETTO, W, coord. Biotecnologia industrial: processos fermentativos e enzimáticos. São Paulo: Edgard Blücher, 2001. v. 3, cap. 24, p. 547-582.

ARAUJO, M. L. G. C.; OlIVEIRA, R. P.; GIORDANO, R. C.; HOKKA, C. O. Comparative studies on cephalosporin $\mathrm{C}$ production process with free and immobilized cells of Cephalosporium acremonium ATCC 48272. Chemical Engineering Science, Oxford, v. 51, n. 11, p. 2835-2840, 1996. 
ARAUJO, M. L. G. C.;GIORDANO, R. C.; HOKKA, C. O. Studies on the respiration rate of free and immobilized cells of Cephalosporium acremonium in cephalosporin $C$ production. Biotechnology and Bioengineering, New York, v. 63, n.5, p.593-600, June. 1999.

ARCAMONE, F. M. From pigments of the actinomycetes to third generation antitumor anthracyclines. Biochimie, Paris, v. 80, n. 3, p. 201-206, Mar. 1998.

ARGIRIOU, T.; KANELLAKI, M.; VOLIOTIS, S.; KOUTINAS, A. A. Kissiris-supported yeast cells: high biocatalytic stability and productivity improvement by successive preservations at $0^{\circ} \mathrm{C}$. J. Agric. Food Chem, Davis, v. 44, p. 4028-4031, 1996.

ASFORA, J. J.; SANTANA, C. F.; LIMA, O. G. Primeiras observações com o uso da retamicina em pacientes portadores de leucemias agudas. Revista do Instituto de Antibióticos, Recife, v. 12, n. 1-2, p.89-99, 1972.

AZEVEDO, J. G. W. Estudo das condições de imobilização de Streptomyces olindensis ICB20 em alginato de cálcio, visando a produção de retamicina. 2005. 109p. Dissertação (Mestrado) - Escola Politécnica, Universidade de São Paulo, São Paulo, 2005.

BAKOYIANIS, V.; KANELLAKI, M.; KALIAFAS, A.; KOUTINAS, A. A. Low temperature wine making by immobilized cells on mineral kissiris. Journal of Agricultural and Food Chemistry, Easton, v. 40, n. 7, p. 1293-1296, July. 1992.

BAILEY, J. E.; OLLIS, D. F. Biochemical engineering fundamentals. $2^{\text {nd }} e d$. New York: McGraw-Hill, 1986. 984p.

BANDYOPADHYAY, A.; DAS, A. K.; MANDAL, S. K. Erytromycin production by Streptomyces erythreus entrapped in calcium alginate beads. Biotechnology Letters, Kew, v. 15, n. 10, p. 1003-1006, Oct. 1993.

BARBOSA JÚNIOR, S. Desenvolvimento de processo de produção de anticorpos monoclonais utilizando técnicas de imobilização de células. 2003. 325p. Tese (Doutorado) - Instituto de Ciências Biomédicas, Universidade de São Paulo, São Paulo, 2003.

BEG, Q. K.; BHUSHAN, B.; KAPOOR, M.; HOONDAL, G. S. Enhanced production of a thermostable xylanase from Streptomyces $s p$. QG-11-3 and its application in biobleaching of eucalyptus kraft pulp. Enzyme and Microbial Technology, Surrey, v. 27, n. 7 , p. $459-466$, Oct. 2000. 
BRANCO, R.; SANTOS, J C.; MURAKAMI, L Y.; MUSSATO, S I.; DRAGONE, G.; SILVA, S. S. Xylitol Production in a bubble column bioreactor: influence of the aeration rate and immobilized system concentration. Process Biochemistry, Oxford, v. 42, n. 2, p. 258-262, Feb. 2006.

BUCKE, C. Cell immobilization in calcium alginate. In: Immobilization techniques for cells/organelles. Methods in Enzymology, San Francisco, v. 135, p. 175-189, 1987.

BUSOVA, K.; MAGYAR, I.; JANKY, F. Effect of immobilized yeasts on the quality of bottle-fermented sparkling wine. Acta Alimentaria, Budapest, v. 23, n. 1, p. 9-23, 1994.

CUNHA, M. A. A.; CONVERTI, A.; SANTOS, J. C.; SILVA, S. S. Yeast immobilization in lentikats:a new strategy for xylitol bioproduction from sugarcane bagasse. World Journal of Microbiology \& Biotechnology, Oxford, v. 22, n. 1, p. 65-72, Jan. 2006.

CARVALHO, W.; SILVA, S. S. ; VITOLO, M. ; FELIPE, M. G. A. ; MANCILHA, I M . Improvement in Xylitol Production from Sugarcane Bagasse Hydrolysate Achieved by the Use of a Repeated-Batch Immobilized Cell System. Zeitschrift für Naturforschung, v. 57(c), p. 109-112, 2002.

CARVALHO, W.; SILVA, S. S.; SANTOS, J. C.; CONVERTI, A. Xylitol production by Ca-alginate entrapped cells: comparison of different fermentation systems. Enzyme and Microbial Technology, Surrey, v. 32, n. 5, p. 553-559, Apr. 2003.

CARVALHO, W.; BATISTA, M. A.; CANILHA, L.; SANTOS, J. C.; CONVERTI, A.; SILVA, S. S. Sugarcane bagasse hydrolysis with phosphoric and sulfuric acids and hydrolysate detoxification for xylitol production. Journal of Chemical Technology and Biotechnology, Oxford, v. 79, n. 11, p. 1308-1312, Nov. 2004a.

CARVALHO, W. Estudo da obtenção de xilitol em hidrolisado de bagaço de cana com células imobilizadas em gel de alginato de cálcio. Tese (Doutorado) Departamento de Biotecnologia, Faculdade de Engenharia Química de Lorena, Lorena, 2004b.

CASTELLAR, M. R.; BORREGO, F.; CANOVAS, M.; IBORRA, J. L. Optimization of the start-up of a passively immobilized Zymomonas mobilis system for continuous ethanol production. Process Biochemistry, Oxford, v. 29, n. 7, p. 569-574, 1994. 
CHANG, HO NAM, MOO-YOUNG, MURRAY. Analysis of oxygen transport in immobilized whole cells. In: MOO-YOUNG, Murray. Bioreactor immobilized enzymes and cells: fundamentals and applications. London: Elsevier Applied Science, 1988. p. 33-51.

CHATER, K. F.; BIBB, M. J. Regulation of bacterial antibiotic production. In: REHM, H.J.; REED, G., (eds.). Biotechnology. $2^{\text {nd }}$ ed. Weinheim, VCH, 1994. p. 57-105.

CHEETHAM, P. S. J.; BLUNT, K. W.; BUCKE, C. Physical studies on cell immobiliation using calcium alginate gels. Biotechnology and Bioengineering, New York, v. 21, n. 12, p.2155-2168, Dec. 1979.

CHIBATA, I.; TOSA, T.; SATO, T. Immobilized biocatalysts to produce aminoacids and other organic compounds. In: LASKIN, A. (Ed.). Enzymes and immobilized cells in biotechnology. Menlo Park: Benjamin/Cummings, $1985 . \quad 317 p$. (Biotechnology series, n. 5.

CHUN, G.; AGATHOS, S. N. Comparative studies of physiological and environmental effects on the prdoduction of cyclosporin $A$ in suspended and immobilized cells of Tolypocladium inflatum. Biotechnology and Bioengineering, New York, v. 37, n. 3, p.256-265, 1991.

COTIAS, C. T.; SANTANA, C. F.; PINTO, K. V. Prevenção das arritmias produzidas pela intoxicação crônica coma retamicina (complexo) pela utilização dos bloqueadores adrenérgicos. Revista do Instituto de Antibiotióticos, Recife, v. 11, n. 1, p. 3-13, 1971.

CUNHA, M. A. A.; CONVERTI, A.; SANTOS, J. C.; SILVA, S. S. Yeast Immobilization in LentiKats:A New Strategy for Xylitol Bioproduction From Sugarcane Bagasse. World Journal of Microbiology \& Biotechnology. v. 22. p. 65-72. 2006a.

CRUZ, A. J. G. ; ALMEIDA, R. M. R. G.; ARAUJO, M. L. G. C. ; GIORDANO, R. C. ; HOKKA, C. O. The dead core model applied to beads with immobilized cells in a fedbatch cephalosporin $C$ production bioprocess. Chemical Engineering Science, v. 56, p. 419-425, 2001.

CRUZ, A. J. G.; PAN, T.; GIORDANO, R. C.; ARAUJO, M. L. C.; HOKKA, C. O. Cephalosporin $\mathrm{C}$ production by immobilized cephalosporium acremonium cells in a repeted batch tower bioreactor. Biotechnology and Bioengineering, New York, v. 85, n. 1, p. 96-112, Jan. 2004. 
DALILI, M. AND CHAU, P. C. Production of actinomycin D with immobilized Streptomyces parvulus under nitrogen and carbon starvation conditions. Biotechnol. Lett, v.10, p. 331-336, 1988.

DEMAIN, A. L.; FANG, A. Emerging concepts of secondary metabolism in Actynomicetes. Actinomycetologica, Tokyo, v.9, n.2, p. 98-117, Dec. 1995.

DEMAIN, A. L.; BAÉZ-VÁSQUEZ, M. A. Immobilized Streptomyces clavuligerus NP1 cells for biotransformation of penicillin $G$ into deacetoxycephalosporin $G$. Applied Biochemistry and Biotechnology, Clifton, v. 87, n. 2, p.135-140, May. 2000.

DEVI, S.; SRIDHAR, P. Production of cephamycin C in repeated batch operations from immobilized streptomyces clavuligerus. Process Biochemistry, Oxford, v.36, n. 3, p.225-231, Oct. 2000.

ECKARDT, K.; WAGNER, C. Biosyntesis of anthracyclinones. Journal Basic of Microbiology, Weinheim, v. 28, n.1-2, p. 137-144, 1988.

ELIBOL, M. Product shifting by controlling medium $\mathrm{pH}$ in immobilised Streptomyces coelicolor A3(2) culture. Process Biochemistry, Oxford, v. 37, n. 12, p. 1381 1386, 2002.

FARID, M. A.; DIWANY, I.; ENSHASY, H. A. Production of oxytetracycline by immobilized streptomyces rimosus celss in calcium alginate gels. Acta Biotechnologica, Berlin, v. 14, n. 3, p. 303-309, Jan. 1994.

FERRARO, L.; FATICHENTI, F.; CIANI, M. Pilot scale vinification process using immobilized candida stellata cells and saccharomyces cerevisiae. Process Biochemistry, Oxford, v. 35, n. 10, p. 1125-1129, July. 2000.

FURLAN, R. L. A Obtenção e estudo de mutantes com produção alterada do antibiótico retamicina sintetizado por Streptomyces olindensis DAUFPE 5622. 1997. 76p. Dissertação (Mestrado) - Instituto de Ciências Biomédicas, Universidade de São Paulo, São Paulo, 1997.

FURLAN, R. L.; GARRIDO, L. M.; BRUMATTI, G.; AMARANTE-MENDES, G. P.; MARTINS, R. A.; FACCIOTTI, M. C. R.; PADILLA, G. A rapid and sensitive method for the screening of DNA intercalating antibiotics. Biotechnology Letters, Kew, v. 24, n. 24, p.1807-1813, Dec. 2002. 
FURLAN, R. L. A.; WATT, S. J.; GARRIDO, L. M.; NUR-E-ALAM, M.; ROHR, J.; BRANA, A.; SALAS, J. A.; BECK, J. L.; SHEIL, M. M.; PADILLA, G. DNA-binding properties of cosmomycin $d$, an anthracycline with two trisaccharide chains. Journal of Antibiotics, Tokyo, v. 57, n. 10, p. 647-654, Oct. 2005.

GARRIDO, L.M. Construção de uma biblioteca genômica de Streptomyces olindensis e triagem dos genes envolvidos na biosíntese do antitumoral retamicina. Dissertação (Mestrado). Instituto de Ciências Biomédicas, Universidade de São Paulo, São Paulo, 2000.

GAITE, J. A. G. Producão de etanol em batelada repetida com reciclo celular completo usando um reator catalítico agitado tipo cesta com leveduras imobilizadas. 1988. 90p. Tese (Doutorado) - Escola Politécnica, Universidade de São Paulo, São Paulo, 1988.

GERBESH, N.; BUCHHOLZ, R. New processes and actual trends in biotechnology. FEMS Microbiology Reviews, Amsterdam, v.16, n. 2-3, p. 259-269, Feb. 1995.

GRÄFE, U.; DORNBERGER, K.; SALUZ, H.-P. Biotechnological drugs as antitumor agents. In: REHM, H.J.; REED, G., Biotechnology. $2^{\text {nd }}$ ed. Weinheim, VCH, v. 7, p. 641-705, 1994.

GRANT, G. T.; MORRIS, E. R.; REES, D. A.; SMITH, P. J. C.; THOM, D. Biological interactions between polysaccharides and divalent cations: the eg-box model. FEBS Letters, Amsterdam, v. 32, n. 1, p. 195-198, May. 1973.

GUIMARÃES, L. M. Influência do preparo do inóculo e do pH na produção do antibiótico retamicina por Streptomyces olindensis So20. $2000.212 p$. Dissertação (Mestrado) - Escola Politécnica, Universidade de São Paulo, São Paulo, 2000.

GUIMARÃES, L.M. Influência de diferentes fontes de carbono e nitrogênio na produção do antitumoral retamicina por Streptomyces olindensis ICB20. 2005. 207p. Tese (Doutorado) - Escola Politécnica, Universidade de São Paulo, São Paulo, 2005.

HEMERT, P.; KILBURN, D. G.; WEZEL, A. L. Homogenous cultivation of animal cells for the production of virus and virus products. Biotechnology and Bioengineering, New York, v. 11, n. 5, p. 875-885, Sept. 1969. 
INOUE, O. O. Influência de diferentes limitações nutricionais sobre a produção de retamicina por streptomyces olindensis ICB20. 2006. 132p. Tese (Doutorado) - Escola Politécnica, Universidade de São Paulo, São Paulo, 2006.

JUAREZ-RAMIREZ, C. RUIZ-ORDAZ, M. CRISTIANI-URBINA, E. GALINDEZMAYER, J. Degradation kinetics of phenol by immobilized cells of Candida tropicalis in a fluidized bed reactor. World Journal of Microbiology and Biotechnology, v.17, n. 7, 2001.

KANTARCI, N.;BORAK F.; UNGEN, K. O. Bubble column reactors: Review. Process Biochemistry, v. 40, p. 2263-2283, 2005.

KAREL, S.F.; LIBICKI, S. B.; ROBERTSON, C.R. The immobilization of whole cells: Engeneering principles. Chemical Engeneering Science. v. 40, p. 1321-1354, 1985.

KHANG, Y.; H. ; SHANKAR, H.; SENATORE, F. Modeling the effect of oxygen mass transfer on $\beta$-lactam antibiotic production by immobilizedCephalosporium acremonium. Biotechnology Letters, Kew, v. 10, n. 12, p. 861-866, Dec. 1988.

KENNEDY, J. F.; CABRAL, J. M. S. Immobilized living cells and their applications. In: WINGARD, L. B., Jr.; KATCHALSKI-KATZIR, E.; GOLDSTEIN, L. (Eds.). Applied biochemistry and bioengineering. New York: Academic Press, 1983. v.4, p.189-245, 1983.

KIM, CHANG JOON.; CHANG, YONG KEUN; CHUN, GIE-TAEK; JEONG YEONHO; LEE, SANG JONG. Continuous culture of immobilized streptomyces cells for kasugamycin production. Biotechnology Progress, New York, v. 17, n.3, p.453461, June. 2001.

KIM, S. J; HAN, B.K.; LEE, G. M. Feasibility study on the use calcium alginateentrapped hybridoma cells for IgM production. Bioprocess Engineering, Berlin, v.12, n. 1-2, p. 65-70, Feb. 1995.

KOURKOUTAS, Y.; BEKATOROU, A.; BANAT, I. M.; MARCHANT, R.; KOUTINAS, A. A. Immobilization technologies and support materials suitable in alcohol beverages production: a review. Food Microbiology, London, V.21, n. 4, p. 377397, Aug. 2004.

LACCA, A. GARCIA, L. A.; DIAZ, M. Analysis and description of the evolution of alginate immobilised cells systems. Journal of Biotechnology, V. 80, p 203-215, 2000. 
LATORRE, L. R. Purificação e caracterização de antraciclinas antibióticas de uma linhagem mutante de Streptomyces olindensis DAUFPE 5622. 2001. 71p. Dissertação (Mestrado) - Instituto de Química, Universidade de São Paulo, São Paulo, 2001.

LEO, W. J. MCLOUGHLIN, A.J.; MALONE, D. M., Effects of Sterilization Treatments on Some Properties of Alginate Solutions and Gels, Biotechnol. Prog., v.6, p.51-53, 1990.

LATORRE, L.R. Purificação e caracterização de antraciclinas antibióticas de uma linhagem mutante de Streptomyces olindensis DAUFPE 5622. 2001. Dissertação (Mestrado). Instituto de Química - Universidade de São Paulo, São Paulo, 2001.

LAVARDA, S.C.S. Avaliação de condições para a imobilização de células de Streptomyces clavuligerus ATCC 27064 para a produção de ácido clavulânico em biorreator tipo torre. 2003. 118p. Tese (Doutorado). Instituto de Química, Universidade Estadual Paulista, Araraquara, 2003.

LAVARDA, S. C. S.; ARAUJO, M. L. G. C. Estudo de condições de imobilização de células de Streptomyces clavuligerus para produção de ácido clavulânico. In: SIMPÓSIO NACIONAL DE FERMENTAÇÕES, 14., 2003, Florianópolis. XIV SINAFERM: anais Florianópolis: UFSC, 2003. Trab.076. 1 CD-ROM.

LECHEVALIER, H. A.; LECHEVALIER, M. P. Introduction to the order Actinomycetales. In: STARR, M. P.; STALP, H.; TRYPER, H. G.; BALAWI, A.; SCHLEGEL, H. G. The prokaryotes: a handbook on habitats, isolation, and identification of bacteria. New York: Springer-Verlag, 1981. p. irregular.

LEE, G. M.; GRAY, J. J.; PALSSON, B. O. Effect of trisodium citrate treatment on hybridoma cell viability. Biotechnology Techniques, Surrey, v. 5, n. 4, p. 295-298, July. 1991.

LEE, TAE HO; CHUN, GIE-TAEK; CHANG, YONG KEUN. Development of sporulation/immobilization method and tis application for the continuous production of cyclosporin A by tolypocladium inflatum. Biotechnology Progress, New York, v. 13, n. 5,p.546-550, Oct. 1997. 
LIMA, O. G.; LYRA, F. D. A.; ALBUQUERQUE, M. M. F.; MACIEL, G. M.; COÊLHO, J. S. B. Primeiras observações sobre o complexo antibiótico e antitumoral retamicina produzido pelo streptomyces olindendis nov. sp. IAUFPe. Revista do Instituto de Antibióticos, Recife, v. 9, n. 1-2, p. 27-37, 1969.

LIMA, R. M. O.; NASCIMENTO, S. C. N.; BIEBER, L. W.; SOUZA, I. A. Ação citotóxica e antitumoral do complexo antitumoral retamicina. Revista Portuguesa de Farmácia, Recife, v. 17, n.1-2, p.23-25, 1992.

MAHMOUD, W.; REHM, H. J. Morphological examination of immobilized Streptomyces aureofaciens during chlortetracycline fermentation. Appl. Microbiol Biotechnol. v. 23, p. 305-310, 1986.

MARTINS, R. A. Transferência de oxigênio e respiração microbiana em cultivos de Streptomyces olindensis So20, visando à produção do antibiótico retamicina. 2001. 157p. Dissertação (Mestrado) - Escola Politécnica, Universidade de São Paulo, São Paulo, 2001.

MARGARITIS, A.; MERCHANT, F. J. A. Advances in ethanol production using immobilized cell systems. Critical Reviews in Biotechnology, Boca Raton, v.1, n. 4, p.339-393, Jan. 1984.

MORIOKA, H.; ETOH, Y.; HORINO, I.; TAKEZAWA, M.; ANDO, T.; HIRAYAMA, K.; $\mathrm{KANO}, \mathrm{H}$.; SHIBAI, $\mathrm{H}$. Production and isolation of cosmomicyns $\mathrm{A}, \mathrm{B}, \mathrm{C}$ and $\mathrm{D}$ new differentiation inducers of friend cell F5-5. Agricultural and Biological Chemistry, Tokyo, v. 49, n. 7, p. 1951-1958, 1985.

NIELSEN, J. The role of metabolic engineering in the production of secondary metabolites. Current opinion in Microbiology, v. 1, p. 330-336, 1998.

OGBONNA, J. C.; MATSUMURA, M.; KATAOKA, H. Effective oxygenation of immobilized cells through reduction in bead diameters: a review. Process Biochemistry, Oxford, v.26, n. 2, p. 109-121, Apr. 1991.

OGBONNA J. C., MASHIMA, H.; TANAKA H. Scale up of fuel ethanol production from sugar beet juice using loofa sponge immobilized bioreactor. Bioresource Technology. v. 76, p. 1-8, 2001.

PAMBOUKIAN, C. R. D. Influência das condições de preparo do inóculo na morfologia do microrganismo e na síntese de glicoamilase por Aspergillus awamori. 1997. 189p. Dissertação (Mestrado) - Escola Politécnica, Universidade de São Paulo, São Paulo, 1997. 
PAMBOUKIAN, C. R. D. Produção do antitumoral retamicina por Streptomyces olindensis em processos descontínuo alimentado e contínuo. 2003. 163p. Tese (Doutorado) - Escola Politécnica, Universidade de São Paulo, São Paulo. 2003.

PAMBOUKIAN, Celso Ricardo Denser ; FACCIOTTI, M. C. R. . Production of the antitumoral retamycin during continuous fermentations of Streptomyces olindensis. Process Biochemistry, Inglaterra, v. 39, n. 12, p. 2249-2255, 2004.

PAMBOUKIAN, C. R. D. ; PINHEIRO, I. R. ; INOUE, O. O; FACCIOTTI, M. C. R. Emprego de diferentes formas de condução do processo fermentativo visando a produção do antitumoral retamicina por Streptomyces olindensis. In: XVI Congresso Brasileiro de Engenharia Química, Santos. Anais do XVI COBEQ, 2006.

PARK, H-J; KHANG, Y-H. Production of cephalosporin $\mathrm{C}$ by immobilized Cephalosporium acremonium in polyethyleneimine-modified barium alginate. Enzyme Microbiology and Technology, v. 17,n.5, p. 408-412, 1995.

PILKINGTON, P. H.; MARGARITIS, A.; MENSOUR, N. A.; RUSSELL, I. Fundamentals of immobilized yeast cells for continuous beer fermentation: a review. Journal of the Institute of Brewing, London, v.104, n. 1, p19-31, 1998.

PINHEIRO, I. R. Estudo da influência das condições de cultivo de Streptomyces olindensis DAUFPE 5622 na produção do antibiótico retamicina. 2003. 100p. Dissertação (Mestrado) - Escola Politécnica, Universidade de São Paulo, São Paulo, 2003.

PRADELLA, J. G. C. Reatores com células imobilizadas. In: LIMA, U. A. et al. Biotecnologia industrial: engenharia bioquímica. São Paulo: Edgard Blücher, 2001. v. 2, p.355-372.

RAMAKRISHNA, S. V.; PRAKASHAM, R. S. Microbial fermentations with immobilized cells. 1999. Disponível em:

http://www.ias.ac.in/currsci/jul10/articles17.htm. Acesso em: 16 fev. 2004.

ROY, D.; GUHA, A.; ROY, M. K.; GHOSH, A. C. In vitro transformation of ampicilin to cephalexin by free and immobilized cells of streptomyces sp. Folia Microbiológica, Praha, v. 43, n. 4, p. 379-382, 1998. 
SARRÀ, M. GÒDIA, F. Continuous production of a hybrid antibiotics by streptomyces lividans tk21 pellets in a three-phase fluidized-bed bioreactor. Biotechnology and Bioengineering, New York, v. 53, n. 6, p. 601-610, Mar. 1996. SARROUH, B. F.; SANTOS, D. T.; SILVA, S. S. Biotechnological production of xylitol in a three-phase fluidized bed bioreactor with immobilized yeast cells in Caalginate beads. Biotechnology Journal, Weinheim, Apr. 2007. no prelo.

SCOTT C. D. Immobilized cells: a review of recent literature. Enzyme Microbial Technology, Surrey, v. 9,n. 2, p. 66-72, Feb. 1987.

SERP,D; CANTANA, E.; HEINZEN, C.; VON-STOCAR, U.; MARSON, I. Characterization of an encapsulation device for the production of monodisperse alginate beads for cell immobilization. Biotechnology and Bioengineering, New York v. 70, p. 41-53, 2000.

SCHMIDELL, W. Agitação e aeração em biorreatores. In: SCHMIDELL, W. et al. Biotecnologia industrial: engenharia bioquímica. São Paulo: Edgard Blücher, 2001. v. 2,cap. 14, p.277-331, 2001.

SILVA, S. S.; SANTOS, J. C.; CARVALHO, W.; ARACAVA, K. K.; VITOLO, M. Use of a fluidized bed reactor operated in semi-continuous mode for xylose-to-xylitol conversion by candida guilliermondii immobilized on porous glass. Process Biochemistry, Oxford, v. 38, n. 6, p. 903-907, Jan. 2002.

SIMÕES, D. A.; ARROYO, G.; URIBELARREA, J. L. Logiciel de Lissage. [S.I.]: [s.n.], 1994. Software.

SRIDEVI, V.; SRIDHAR, P. Effect of support materials on cephamycin C production by immobilized streptomyces clavuligerus. Indian Journal of Experimental Biology, New Delhi, v. 37, n. 3, p. 274-279, 1999.

SRIDEVI, V.; SRIDHAR, P. Production of cephamycin C in repeated batch operations from immobilized streptomyces clavuligerus. Process Biochemistry, Oxford, v. 36, n. 3, p. 225-231, Oct. 2000.

SRINIVASULU, B.; PRAKASHAM, R. S.; JETTY, A.; SRINIVAS, S.; ELLAIAH, P. ; RAMAKRISHNA, S. V. Neomycin production with free and immobilized cells of streptomyces marinensis in airlift reactor. Process Biochemistry, Oxford, v.38, n. 4, p. 593-598, Dec. 2002. 
SRINIVASULU, B.; ADINARAYANA, K.; ELLAIAH, P. Studies on neomycin production using immobilized cells of $S$. marinensis NUV-5 in various reactor configurations: a technical note. AAPS Pharmscitech. v. 4, n. 3, Art. 46, Sep 2003a. Não paginado.

SRINIVASULU, B.; ADINARAYANA, K.; ELLAIAH, P. Investigations on neomycin production with immobilized cells of streptomyces marinensis NUV-5 in calcium alginate matrix. AAPS Pharmscitech. v. 4, n. 4, art. 57, Oct. 2003. não paginado

SRINIVASULU, B.; ELLAIAH, P. Production of neomycin using immobilized cells of Streptomyces marinensis NUV-5. Saudi Pharmaceutical Journal. V. 13. p. 74-82. 2005.

STROHL, W. R. (Ed.) Biotechnology of antibiotics. New York: M. Deckker, 1997. v.82.

SUZZI, G.; ROMANO, P.; VANNINI, L.; TURBANTI, L.; DOMIZIO, P. Cell-recycle batch fermentation using immobilized cells of flocculent saccharomyces cerevisiae wine strains. World Journal of Microbiology and Biotechnology, v. 12, n. 1, p. 25-27, Jan. 1996.

TAKASHIMA, Y.; NAKAJIMA, H.; SONOMOTO, K.; TANAKA, A. Production of daunorubicin by immobilized growing Streptomyces peucetius cells. Applied Microbiology and Biotechnology, Berlin, v. 27, n. 2, p. 106-109, Nov.. 1987.

TAVARES, L. B. B. Fermentação alcoólica de material amiláceo por levedura amilolítica recombinante em reator com células imobilizadas. 1998. 24p. Tese (Doutorado) - Escola Politécnica, Universidade de São Paulo, São Paulo, 1998.

TERUEL, M. L. A.; GONTIER, E.; BIENAIME, E.; SAUCEDO, J. E. N.; BARBOTIN, J. $N$. Response surface analysis of chlortetracycline and tetracycline and tetracycline production with K-carragenan immobilized streptomyces aureiofaciens. Enzyme and Microbial Technology, Surrey, v. 21, n. 5, p. 314-320, Oct. 1997.

TUOMI, T.; HEINO, M.; ROSENQVIST, H.; NORDTRÖM, K.; LAAKSO, S. Fiber fractions from processing of barley in production and conservation of a biologic control agent. Applied Biochemistry and Biotechnology, Clifton, v. 94, n. 2, p. 135-145, May. 2001.

ULGEN, K. O.; MAVITUNA, F. Comparisson of the activity of immobilized and freely suspende streptomyces coelicolor A3(2). Applied Microbiology and Biotechnology, v. 41, n. 2, p. 197-202Apr. 1994. 
VEELKEN, M.; PAPE, H. Production of tylosin and nikkomycin by immobilized streptomyces cells. European Journal of Applied Microbiology and Biotechnology, Berlin, v.15, n. 4, p. 206-210, Dec. 1982.

VORLOP, K. D.; KLEIN, J. Entrapment of microbial cells in chitosan. Methods in Enzymology, New York, v. 135, p. 259-269, 1987.

YANG, S. S.; YUEH, C. Y. Oxytetracycline production by immobilized Streptomyces rimosus. Journal of Microbiology, Immunology and Infection, Taiwan, v. 34, n. 4, p.235-242,dec. 2001.

WANG, J.Y.T.; CHAO, M.; WANG, A.H.-J. Adducts of DNA and anthacycline antibiotics: structures, interactions and activities. In: National Meeting of the American Chemical Society, p. 168-181, 1995.

WEZEL, A. L. et al. New approach to the production of concentrated and purified inactivated polio and rabies tissue culture vaccines. Developments in Biological. Standardization, Basel, v. 41, p 159-168, 1978.

WIJFFELS, R. H. Diffusionn limitation. In: Immobilized cells. Heidelberg Springer Verlag; 2001.

WILLAERT, R. G.; BARON, G. V.; DE BACKER, L. Immobilised living cell systems: modeling and experimental methods. Chichester: John Wiley \& Sons, 1996. 386p.

ZHANG, $\mathrm{H}$. et al. The interaction of sodium alginate with univalent cations. Biopolymers, New York, v. 46, n. 6, p. 395-402, nov. 1998. 


\section{APÊNDICE A}

Tabela A1 - Resultados experimentais do ensaio SL-500

\begin{tabular}{|c|c|c|c|}
\hline Tempo (horas) & $\mathrm{X}_{\mathrm{M}, \mathrm{R}}(\mathrm{g} / \mathrm{L})$ & $\mathrm{S}(\mathrm{g} / \mathrm{L})$ & $\mathrm{R}(\mathrm{UA})$ \\
\hline 0 & 0,47 & 9,7 & - \\
\hline 4 & 0,54 & 10,3 & - \\
\hline 6 & 1,22 & 9,8 & - \\
\hline 12 & 3,07 & 5,9 & 0,000 \\
\hline 16 & 2,39 & 4,3 & 0,246 \\
\hline 20 & 5,67 & 2,1 & 0,600 \\
\hline 24 & 4,70 & 0,9 & 1,208 \\
\hline 28 & 6,55 & 0,0 & 1,332 \\
\hline 32 & 6,67 & 0,0 & 1,458 \\
\hline 36 & 6,41 & 0,0 & 1,460 \\
\hline 40 & 5,41 & 0,0 & 1,300 \\
\hline 44 & 5,71 & 0,0 & 1,488 \\
\hline 52 & 5,21 & 0,0 & 1,366 \\
\hline
\end{tabular}

Tabela A2 - Resultados experimentais do ensaio SI-500

\begin{tabular}{|c|c|c|c|c|c|}
\hline Tempo (horas) & $\mathrm{X}_{\mathrm{M}, \mathrm{R}}(\mathrm{g} / \mathrm{L})$ & $\mathrm{X}_{\mathrm{I}, \mathrm{R}}(\mathrm{g} / \mathrm{L})$ & $\mathrm{X}_{\mathrm{T}}(\mathrm{g} / \mathrm{L})$ & $\mathrm{S}(\mathrm{g} / \mathrm{L})$ & $\mathrm{R}(\mathrm{UA})$ \\
\hline 0 & 0,42 & 0,20 & 0,63 & 10,1 & \\
\hline 4 & 0,11 & 0,07 & 0,31 & 8,3 & \\
\hline 8 & 0,79 & 0,52 & 1,31 & 9,8 & \\
\hline 12 & 0,32 & 1,38 & 1,70 & 8,3 & \\
\hline 16 & 0,27 & 2,05 & 2,32 & 8,6 & 0,000 \\
\hline 24 & 0,27 & 3,61 & 3,88 & 6,8 & 0,088 \\
\hline 30 & 0,15 & 4,21 & 4,36 & 5,3 & 0,252 \\
\hline 42 & 0,16 & 4,19 & 4,73 & 3,0 & 0,720 \\
\hline 48 & 0,15 & 4,61 & 4,76 & 2,8 & 0,820 \\
\hline 54 & 0,11 & 4,82 & 4,92 & 1,0 & 1,028 \\
\hline 68 & 0,13 & 5,25 & 5,15 & 0,0 & 1,222 \\
\hline 74 & 0,17 & 4,90 & 5,07 & 0,0 & 1,158 \\
\hline 92 & 0,51 & 4,40 & 4,90 & 0,0 & 0,972 \\
\hline
\end{tabular}

Tabela A3 - Resultados experimentais do ensaio SI-300

\begin{tabular}{|c|c|c|c|c|c|}
\hline Tempo (horas) & $\mathrm{X}_{\mathrm{M}, \mathrm{R}}(\mathrm{g} / \mathrm{L})$ & $\mathrm{X}_{\mathrm{I}, \mathrm{R}}(\mathrm{g} / \mathrm{L})$ & $\mathrm{X}_{\mathrm{T}}(\mathrm{g} / \mathrm{L})$ & $\mathrm{S}(\mathrm{g} / \mathrm{L})$ & $\mathrm{R}(\mathrm{UA})$ \\
\hline 0 & 0,13 & 0,40 & 0,53 & 10,3 & - \\
\hline 6 & 0,13 & 0,55 & 0,68 & 10,1 & - \\
\hline 12 & 0,17 & 1,57 & 1,74 & 9,8 & - \\
\hline 18 & 0,11 & 2,62 & 2,73 & 7,9 & - \\
\hline 24 & 0,10 & 2,67 & 2,77 & 7,4 & - \\
\hline 32 & 0,17 & 4,06 & 4,23 & 6,1 & 0 \\
\hline 36 & 0,16 & 4,35 & 4,51 & 5,1 & 0,068 \\
\hline 42 & 0,30 & 4,42 & 4,72 & 4,2 & 0,096 \\
\hline 48 & 0,45 & 3,59 & 4,03 & 3,2 & 0,148 \\
\hline 54 & 0,38 & 4,08 & 4,46 & 2,4 & 0,188 \\
\hline 68 & 1,39 & 2,98 & 4,37 & 0,0 & 0,428 \\
\hline 74 & 1,76 & 2,68 & 4,44 & 0,0 & 0,576 \\
\hline 94 & 1,98 & 2,29 & 4,27 & 0,0 & 0,624 \\
\hline
\end{tabular}


Tabela A4 - Resultados experimentais do ensaio SI-300-80

\begin{tabular}{|c|c|c|c|c|c|}
\hline Tempo (horas) & $\mathrm{X}_{\mathrm{M}, \mathrm{R}}(\mathrm{g} / \mathrm{L})$ & $\mathrm{X}_{\mathrm{I}, \mathrm{R}}(\mathrm{g} / \mathrm{L})$ & $\mathrm{X}_{\mathrm{T}}(\mathrm{g} / \mathrm{L})$ & $\mathrm{S}(\mathrm{g} / \mathrm{L})$ & $\mathrm{R}(\mathrm{UA})$ \\
\hline 0 & 0,25 & 0,28 & 0,53 & 10,0 & - \\
\hline 4 & 0,32 & 0,50 & 0,81 & 9,7 & - \\
\hline 8 & 0,21 & 0,84 & 1,05 & 9,7 & - \\
\hline 12 & 0,44 & 1,50 & 1,94 & 9,0 & - \\
\hline 16 & 0,15 & 2,82 & 2,98 & 8,3 & - \\
\hline 20 & 0,16 & 2,98 & 3,14 & 7,6 & - \\
\hline 24 & 0,10 & 3,08 & 3,18 & 6,2 & 0,072 \\
\hline 30 & 0,22 & 2,70 & 2,92 & 6,4 & 0,068 \\
\hline 42 & 0,50 & 2,46 & 2,96 & 4,7 & 0,246 \\
\hline 48 & 0,24 & 2,07 & 2,31 & 3,7 & 0,220 \\
\hline 54 & 0,74 & 2,09 & 2,82 & 3,4 & 0,254 \\
\hline 68 & 0,66 & 2,99 & 3,65 & 2,6 & 0,260 \\
\hline
\end{tabular}

Tabela A5 - Resultados experimentais do ensaio $\mathrm{Cl}-02$

\begin{tabular}{|c|c|c|c|c|c|}
\hline Tempo (horas) & $\mathrm{X}_{\mathrm{M}, \mathrm{R}}(\mathrm{g} / \mathrm{L})$ & $\mathrm{X}_{\mathrm{I}, \mathrm{R}}(\mathrm{g} / \mathrm{L})$ & $\mathrm{X}_{\mathrm{T}}(\mathrm{g} / \mathrm{L})$ & $\mathrm{S}(\mathrm{g} / \mathrm{L})$ & $\mathrm{R}(\mathrm{UA})$ \\
\hline 0 & 0,23 & 0,63 & 0,85 & 12,5 & \\
\hline 4 & 0,23 & 0,55 & 0,78 & 9,7 & \\
\hline 8 & 0,23 & 0,81 & 1,03 & 9,7 & \\
\hline 12 & 0,11 & 1,70 & 1,81 & 9,4 & \\
\hline 16 & 0,05 & 2,70 & 2,75 & 8,6 & \\
\hline 20 & 0,11 & 3,18 & 3,28 & 7,2 & \\
\hline 24 & 0,09 & 4,41 & 4,50 & 6,0 & 0,048 \\
\hline 28 & 0,09 & 5,26 & 5,35 & 4,7 & 0,152 \\
\hline 34 & 0,17 & 5,55 & 5,71 & 10,6 & 0,120 \\
\hline 38 & 0,13 & 6,23 & 6,35 & 11,9 & 0,064 \\
\hline 42 & 0,11 & 6,79 & 6,90 & 12,2 & 0,020 \\
\hline 46 & 0,45 & 5,93 & 6,38 & 12,4 & 0,040 \\
\hline 50 & 0,45 & 6,99 & 7,44 & 12,2 & 0,040 \\
\hline 54 & 0,09 & 6,70 & 6,79 & 12,2 & 0,040 \\
\hline
\end{tabular}

Tabela A6 - Resultados experimentais do ensaio Cl-005-30

\begin{tabular}{|c|c|c|r|r|r|}
\hline Tempo (horas) & $\mathrm{X}_{\mathrm{M}, \mathrm{R}}(\mathrm{g} / \mathrm{L})$ & $\mathrm{X}_{\mathrm{I}, \mathrm{R}}(\mathrm{g} / \mathrm{L})$ & $\mathrm{X}_{\mathrm{T}}(\mathrm{g} / \mathrm{L})$ & $\mathrm{S}(\mathrm{g} / \mathrm{L})$ & $\mathrm{R}(\mathrm{UA})$ \\
\hline 0 & - & 0,60 & - & 10 & \\
\hline 24 & 0,12 & - & - & 7,7 & 0,040 \\
\hline 30 & 0,08 & 6,00 & 6,08 & 7,6 & 0,176 \\
\hline 50 & 0,06 & 7,22 & 7,28 & 7,3 & 0,108 \\
\hline 70 & 1,23 & 4,70 & 5,93 & 7,5 & 0,094 \\
\hline 94 & 2,31 & 2,33 & 4,64 & 1,7 & 0,080 \\
\hline
\end{tabular}


Tabela A7 - Resultados experimentais do ensaio Cl-005-72

\begin{tabular}{|c|c|c|c|c|c|}
\hline Tempo (horas) & $\mathrm{X}_{\mathrm{M}, \mathrm{R}}(\mathrm{g} / \mathrm{L})$ & $\mathrm{X}_{\mathrm{I}, \mathrm{R}}(\mathrm{g} / \mathrm{L})$ & $\mathrm{X}_{\mathrm{T}}(\mathrm{g} / \mathrm{L})$ & $\mathrm{S}(\mathrm{g} / \mathrm{L})$ & $\mathrm{R}(\mathrm{UA})$ \\
\hline 0 & 0,07 & 0,63 & 0,69 & 9,0 & \\
\hline 54 & 0,12 & - & - & 3,2 & 0,400 \\
\hline 72 & 0,78 & 6,13 & 6,91 & 1,7 & 0,700 \\
\hline 96 & 2,35 & 7,60 & 9,95 & 5,6 & 0,152 \\
\hline 120 & 3,15 & 6,82 & 9,97 & 2,9 & 0,320 \\
\hline 152 & 3,38 & 5,45 & 8,83 & 0,0 & 0,308 \\
\hline
\end{tabular}

Tabela A8 - Resultados experimentais do ensaio IC1

\begin{tabular}{|c|c|c|c|c|c|}
\hline Tempo (horas) & $\mathrm{X}_{\mathrm{M}, \mathrm{R}}(\mathrm{g} / \mathrm{L})$ & $\mathrm{X}_{\mathrm{I}, \mathrm{R}}(\mathrm{g} / \mathrm{L})$ & $\mathrm{X}_{\mathrm{T}}(\mathrm{g} / \mathrm{L})$ & $\mathrm{S}(\mathrm{g} / \mathrm{L})$ & $\mathrm{R}(\mathrm{UA})$ \\
\hline 0 & 0,00 & 0,57 & 0,57 & 13,0 & - \\
\hline 6 & 0,00 & - & - & 10,2 & - \\
\hline 12 & 0,00 & - & - & 9,3 & - \\
\hline 18 & 0,00 & 2,62 & 2,62 & 8,1 & - \\
\hline 24 & 0,15 & 3,13 & 3,27 & 6,7 & 0,000 \\
\hline 32 & 0,16 & 3,23 & 3,39 & 6,1 & 0,208 \\
\hline 44 & 0,40 & 3,69 & 4,10 & 4,5 & 0,443 \\
\hline 60 & 1,33 & 3,62 & 4,95 & 0,2 & 0,716 \\
\hline 72 & 1,18 & 3,78 & 4,96 & 0,0 & 0,776 \\
\hline
\end{tabular}

Tabela A9 - Resultados experimentais do ensaio IC2

\begin{tabular}{|c|c|c|c|c|c|}
\hline Tempo (horas) & $\mathrm{X}_{\mathrm{M}, \mathrm{R}}(\mathrm{g} / \mathrm{L})$ & $\mathrm{X}_{\mathrm{I}, \mathrm{R}}(\mathrm{g} / \mathrm{L})$ & $\mathrm{X}_{\mathrm{T}}(\mathrm{g} / \mathrm{L})$ & $\mathrm{S}(\mathrm{g} / \mathrm{L})$ & $\mathrm{R}(\mathrm{UA})$ \\
\hline 0 & 0,00 & 0,53 & 0,53 & 10,6 & - \\
\hline 4 & 0,20 & 0,49 & 0,49 & 10,2 & - \\
\hline 8 & 0,28 & 0,66 & 0,66 & 9,3 & - \\
\hline 12 & 0,23 & 1,41 & 1,41 & 8,1 & - \\
\hline 20 & 0,20 & 3,17 & 3,32 & 7,0 & 0,000 \\
\hline 28 & 0,21 & 4,26 & 4,41 & 6,1 & 0,126 \\
\hline 40 & 0,32 & 4,66 & 4,90 & 4,5 & 0,290 \\
\hline 48 & 0,99 & 3,94 & 4,68 & 0,2 & 0,620 \\
\hline 60 & 1,00 & 3,52 & 4,27 & 0,0 & 0,720 \\
\hline 72 & 1,43 & 3,08 & 4,16 & 0,0 & 0,780 \\
\hline
\end{tabular}

Tabela A10 - Resultados experimentais do ensaio IC3

\begin{tabular}{|c|c|c|c|c|c|}
\hline Tempo (horas) & $\mathrm{X}_{\mathrm{M}, \mathrm{R}}(\mathrm{g} / \mathrm{L})$ & $\mathrm{X}_{\mathrm{l}, \mathrm{R}}(\mathrm{g} / \mathrm{L})$ & $\mathrm{X}_{\mathrm{T}}(\mathrm{g} / \mathrm{L})$ & $\mathrm{S}(\mathrm{g} / \mathrm{L})$ & $\mathrm{R}(\mathrm{UA})$ \\
\hline 0 & 0,00 & 0,65 & 0,66 & 9,4 & - \\
\hline 6 & 0,00 & - & - & 9,0 & - \\
\hline 11 & 0,00 & 1,63 & 1,63 & 6,4 & 0,000 \\
\hline 19 & 0,00 & 3,74 & 3,74 & 5,4 & 0,070 \\
\hline 26 & 19,50 & 3,95 & 4,06 & 3,9 & 0,160 \\
\hline 33 & 24,75 & 3,91 & 3,96 & 2,0 & 0,466 \\
\hline 45 & 33,75 & 4,26 & 4,45 & 0,0 & 0,610 \\
\hline 72 & 54,00 & 4,34 & 5,00 & 0,0 & 0,760 \\
\hline
\end{tabular}


Tabela A11 - Resultados experimentais do ensaio LC1

\begin{tabular}{|c|c|c|c|}
\hline Tempo (horas) & $\mathrm{X}_{\mathrm{M}, \mathrm{R}}(\mathrm{g} / \mathrm{L})$ & $\mathrm{S}(\mathrm{g} / \mathrm{L})$ & $\mathrm{R}(\mathrm{UA})$ \\
\hline 0 & 0,46 & 10,9 & - \\
\hline 4 & 0,68 & 10,3 & - \\
\hline 8 & 1,79 & 10,0 & - \\
\hline 12 & 3,24 & 8,1 & 0,000 \\
\hline 17 & 4,24 & 5,5 & 0,092 \\
\hline 23 & 4,55 & 4,8 & 0,212 \\
\hline 29 & 5,08 & 3,2 & 0,428 \\
\hline 35 & 6,75 & 2,0 & 0,562 \\
\hline 45 & 6,76 & 0,0 & 0,640 \\
\hline 50 & 6,42 & 0,0 & 0,640 \\
\hline \multicolumn{4}{|c}{} \\
\hline
\end{tabular}

Tabela A12 - Resultados experimentais do ensaio LC2

\begin{tabular}{|c|c|c|c|}
\hline tempo & $\mathrm{X}_{\mathrm{M}, \mathrm{R}}(\mathrm{g} / \mathrm{L})$ & $\mathrm{S}(\mathrm{g} / \mathrm{L})$ & $\mathrm{R}(\mathrm{UA})$ \\
\hline 0 & 0,35 & 10,015 & \\
\hline 4 & 0,59 & 8,035 & \\
\hline 8 & 1,66 & 8,935 & \\
\hline 12 & 3,42 & 7,135 & \\
\hline 16 & 4,25 & 4,615 & \\
\hline 20 & 4,63 & 3,718 & 0 \\
\hline 26 & 5,58 & 1,1036 & 0,12 \\
\hline 32 & 5,50 & 0,2 & 0,3 \\
\hline 38 & 5,61 & 0 & 0,32 \\
\hline 46 & 5,17 & 0 & 0,49 \\
\hline 53 & - & - & 0,45 \\
\hline
\end{tabular}

Tabela A13 - Resultados experimentais do ensaio LC3

\begin{tabular}{|c|c|c|c|}
\hline tempo & $\mathrm{X}_{\mathrm{M}, \mathrm{R}}(\mathrm{g} / \mathrm{L})$ & $\mathrm{S}(\mathrm{g} / \mathrm{L})$ & $\mathrm{R}(\mathrm{UA})$ \\
\hline 0 & 0,32 & 10,7 & - \\
\hline 4 & 0,44 & 10,5 & - \\
\hline 7 & 0,93 & 10,0 & - \\
\hline 11 & 2,41 & 7,1 & - \\
\hline 15 & 4,45 & 6,4 & 0 \\
\hline 19 & 5,84 & 5,7 & 0,1 \\
\hline 24 & 6,64 & 4,5 & 0,28 \\
\hline 30 & 6,58 & 0,0 & 0,36 \\
\hline 38 & 5,48 & 0,0 & 0,58 \\
\hline 48 & 4,93 & 0,0 & 0,6 \\
\hline
\end{tabular}


Tabela A14 - Resultados experimentais do ensaio IC-C1

\begin{tabular}{|c|c|c|c|c|r|}
\hline Tempo (horas) & $\mathrm{X}_{\mathrm{M}, \mathrm{R}}(\mathrm{g} / \mathrm{L})$ & $\mathrm{X}_{\mathrm{I}, \mathrm{R}}(\mathrm{g} / \mathrm{L})$ & $\mathrm{X}_{\mathrm{T}}(\mathrm{g} / \mathrm{L})$ & $\mathrm{S}(\mathrm{g} / \mathrm{L})$ & $\mathrm{R}(\mathrm{UA})$ \\
\hline 0 & 0,00 & 0,62 & 0,62 & 10,0 & - \\
\hline 24 & 0,07 & 4,16 & 4,23 & 3,2 & 0 \\
\hline 48 & 0,17 & 3,91 & 4,08 & 0,3 & 0,63 \\
\hline 50 & - & - & - & 9,8 & - \\
\hline 74 & 1,61 & - & - & 4,8 & 0,36 \\
\hline 98 & 3,40 & 4,75 & 8,16 & 4,6 & 0,34 \\
\hline 120 & 2,62 & 3,16 & 5,79 & 4,8 & 0,3 \\
\hline 168 & 3,94 & 1,98 & 5,91 & 0,0 & 0,65 \\
\hline 200 & - & - & - & 0,0 & - \\
\hline 216 & 3,54 & 2,08 & 5,62 & 0,5 & 0,46 \\
\hline 240 & 3,72 & 1,94 & 5,66 & 0,0 & 0,36 \\
\hline
\end{tabular}

Tabela A15 - Resultados experimentais do ensaio IC-C2

\begin{tabular}{|c|c|c|c|c|c|}
\hline Tempo (horas) & $\mathrm{X}_{\mathrm{M}, \mathrm{R}}(\mathrm{g} / \mathrm{L})$ & $\mathrm{X}_{\mathrm{I}, \mathrm{R}}(\mathrm{g} / \mathrm{L})$ & $\mathrm{X}_{\mathrm{T}}(\mathrm{g} / \mathrm{L})$ & $\mathrm{S}(\mathrm{g} / \mathrm{L})$ & $\mathrm{R}(\mathrm{UA})$ \\
\hline 0 & 0,00 & 0,57 & 0,57 & 10,0 & - \\
\hline 24 & 0,10 & 2,76 & 2,86 & 6,0 & 0,000 \\
\hline 36 & 0,11 & 4,59 & 4,70 & 4,6 & 0,427 \\
\hline 48 & 1,09 & 4,72 & 5,81 & 1,8 & 0,830 \\
\hline 72 & 1,70 & 4,52 & 6,21 & 1,6 & 0,800 \\
\hline 96 & 2,81 & 6,01 & 8,82 & 0,8 & 0,800 \\
\hline 120 & 3,00 & 4,70 & 7,70 & 1,4 & 0,796 \\
\hline 144 & 3,15 & 4,08 & 7,23 & 1,6 & 0,750 \\
\hline
\end{tabular}

Tabela A16 - Resultados experimentais do ensaio SI-BR1

\begin{tabular}{|c|c|c|c|c|}
\hline Tempo (horas) & $\mathrm{X}_{\mathrm{M}, \mathrm{R}}(\mathrm{g} / \mathrm{L})$ & $\mathrm{X}_{\mathrm{I}, \mathrm{R}}(\mathrm{g} / \mathrm{L})$ & $\mathrm{S}(\mathrm{g} / \mathrm{L})$ & $\mathrm{R}(\mathrm{UA})$ \\
\hline 0 & 0,24 & 0,22 & 10,1 & - \\
\hline 17 & 0,08 & - & 8,5 & 0,000 \\
\hline 26 & 0,09 & - & 6,5 & 0,058 \\
\hline 42 & 0,05 & - & 5,2 & 0,372 \\
\hline 50 & 0,12 & - & 4,2 & 0,495 \\
\hline 68 & 0,17 & - & 1,1 & 0,680 \\
\hline 90 & 1,05 & 1,58 & 0,0 & 0,780 \\
\hline 92 & 0,23 & 1,58 & 11,3 & 0,100 \\
\hline 98 & 0,71 & - & 9,0 & 0,256 \\
\hline 114 & 4,36 & - & 2,4 & 0,906 \\
\hline 122 & 3,84 & - & 0,0 & 1,324 \\
\hline 142 & 3,28 & 3,11 & 0,0 & 1,680 \\
\hline 144 & 0,62 & 3,11 & 10,3 & 0,160 \\
\hline 148 & 0,28 & - & 8,3 & 0,332 \\
\hline 160 & 1,37 & - & 6,0 & 0,686 \\
\hline 170 & 3,12 & - & 4,5 & 0,847 \\
\hline 186 & 3,45 & - & 0,0 & 1,508 \\
\hline 190 & 2,78 & 2,75 & 0,0 & 1,708 \\
\hline
\end{tabular}


Tabela A17 - Resultados experimentais do ensaio SI-BR1

\begin{tabular}{|c|c|c|c|c|}
\hline Tempo (horas) & $\mathrm{X}_{\mathrm{M}, \mathrm{R}}(\mathrm{g} / \mathrm{L})$ & $\mathrm{X}_{\mathrm{I}, \mathrm{R}}(\mathrm{g} / \mathrm{L})$ & $\mathrm{S}(\mathrm{g} / \mathrm{L})$ & $\mathrm{R}(\mathrm{UA})$ \\
\hline 0 & 0,14 & 0,68 & 7,5 & - \\
\hline 6 & 0,09 & & 9,0 & - \\
\hline 12 & 0,08 & & 8,1 & - \\
\hline 24 & 0,04 & & 5,4 & 0,000 \\
\hline 48 & 0,06 & & 3,5 & 0,058 \\
\hline 71 & 0,08 & & 0,9 & 0,822 \\
\hline 77 & 0,06 & 2,59 & 0,0 & 0,812 \\
\hline 79 & 0,17 & 2,59 & 9,0 & 0,242 \\
\hline 94 & 0,70 & & 6,5 & 0,380 \\
\hline 109 & 3,15 & & 5,0 & 0,570 \\
\hline 118 & 2,86 & & 4,9 & 1,314 \\
\hline 125 & 2,52 & 3,780 & 0,0 & 1,376 \\
\hline 127 & 1,26 & 3,780 & 7,9 & 0,400 \\
\hline 139 & 3,28 & & 6,9 & 0,726 \\
\hline 151 & 3,17 & & 1,4 & 1,200 \\
\hline 166 & 2,20 & 5,23 & 0,0 & 1,500 \\
\hline
\end{tabular}

Tabela A18 - Resultados experimentais do ensaio IC-BR

\begin{tabular}{|c|c|c|c|c|c|c|c|c|c|c|c|c|c|c|}
\hline & 1 & - & 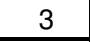 & 4 & 5 & 6 & 1 & - & 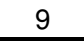 & 10 & 11 & 12 & 13 & 14 \\
\hline$f f(h)$ & 71 & 48 & 44 & 5,5 & 5 & 47,5 & 36 & 35 & 36 & 24,5 & 35,5 & 34 & 35,5 & 35,5 \\
\hline & & & 7 & 8,2 & 8,2 & 8,4 & $x^{2}+2$ & $x^{2}+2+$ & 7,2 & 94 & - & 6,8 & 7 & 7,2 \\
\hline & 52 & 4,18 & 4,12 & 2,55 & 2,62 & 2,91 & 1,88 & 1,58 & 2,31 & 2,39 & 2,39 & 2,39 & 39 & 2,39 \\
\hline & & & $2,, 00$ & 2,62 & 2,91 & 1,88 & 1,58 & 2,39 & 2,00 & 2,00 & 2,39 & 2,39 & 2,39 & 2,39 \\
\hline $\mathrm{XM}$ & 00 & 0,11 & 0,01 & 8 & 0,20 & 0,29 & 41 & 31 & 28 & 28 & 82 &, 23 &, 27 & 0,50 \\
\hline$X N$ & 02 & 4,06 & 4,69 & 4,25 & 2,89 & 4,58 & 5,00 & 3,72 & 3,75 & 4,09 & 4,45 & 4,42 & 4,66 & 3,23 \\
\hline & 52 & 4,29 & 4,12 & 2,83 & 2,82 & 3,20 & 2,29 & 1,88 & 2,59 & 2,67 & 3,21 & 3,62 & 2,66 & 2,89 \\
\hline & & & 7,24 & 6,87 & 5,80 & 6,46 & 6,58 & $c$ & 6,15 & 6,4 & 6,84 & 6,81 & 7,05 & 5,62 \\
\hline & 00 & 188 & 0,160 & 0,180 & 0,206 & 0,180 & 0,140 & 0,090 & 0,052 & 0,100 & 0,066 & 0,102 & 0,060 & 0,090 \\
\hline $\mathrm{R}$ & 680 & \begin{tabular}{|l|}
0,800 \\
\end{tabular} & 0,600 & 0,840 & 0,720 & 0,480 & 0,590 & 0,616 & 0,830 & 0,244 & 0,460 & 0,434 & 486 & 0,298 \\
\hline C & 080 & 0,081 & 0,071 & 0,114 & 0,086 & 0,069 & 0,119 & 0,121 & 0,099 & 0,155 & 0,102 & 0,094 & 0,124 & 0,077 \\
\hline $\mathrm{PR}($ & 010 & 0,013 & 0,010 & 0,019 & 0,015 & 0,006 & 0,013 & 0,015 & 0,022 & 0,006 & 0,011 & 0,010 & 0,012 & 0,006 \\
\hline $\mathrm{YR} / \mathrm{S}(\mathrm{UA} /(\mathrm{g} / \mathrm{L}))$ & 080 & 0,072 & 0,052 & 0,078 & 0,060 & 0,035 & 0,053 & 0,062 & 0,092 & 0,017 & 0,046 & 0,039 & 050 & 024 \\
\hline $\mathrm{YX} / \mathrm{S}(\mathrm{g} / \mathrm{g})$ & 0,668 & 0,458 & 0,366 & 0,475 & 0,350 & 0,384 & 0,505 & 0,498 & 0,419 & 0,448 & 0,427 & 0,375 & 0,517 & 0,322 \\
\hline $\operatorname{Resp}(\mathrm{UA} /(\mathrm{g} / \mathrm{L}))$ & 120 & 0,157 &, 141 & 0,163 & 0,173 & 0,092 & 0,105 & 0,124 & 0,219 & 0,038 & 0,109 & 0,104 & 0,097 & 0,0 \\
\hline
\end{tabular}




\section{APÊNDICE B}

\section{B.1. Ensaios para determinação do coeficiente volumétrico de transferência de oxigênio (Kla) e respiração nos biorreatores cesta e coluna de bolhas.}

\section{B.1.1. Determinação do Coeficiente volumétrico de transferência de oxigênio}

A determinação do coeficiente volumétrico de transferência de oxigênio (Kla) foi efetuada aplicando o método dinâmico, no qual um eletrodo específico para a medida de oxigênio dissolvido em meio líquido (Ingold - Inpro 6110) foi ligado a um transmissor que registrou os sinais de concentração a partir do zero até a concentração de saturação (SCHMIDELL, 2001).

As condições empregadas para a determinação do Kla nos diferentes biorreatores e sistemas empregados encontram-se na tabela B.1, a seguir:

Tabela B1 - Condições dos experimentos para determinação do Kla nos biorreatores tipo cesta e coluna de bolhas

\begin{tabular}{|c|c|}
\hline Ensaio & Condição \\
\hline STR (sem cesta- sem gel) & $1 \mathrm{vvm} \mathrm{/} \mathrm{500} \mathrm{rpm}$ \\
\hline STR (com cesta- sem gel) & $1 \mathrm{vvm} / 300,500$ e $700 \mathrm{rpm}$ \\
\hline STR (com cesta - com gel) & $1 \mathrm{vvm} / 300,500$ e $700 \mathrm{rpm}$ \\
\hline Coluna sem gel de alginato & $0,5 / 1 / 1,5 / 2 / 3 \mathrm{vvm}$ \\
\hline Coluna com gel de alginato & $1 / 2 / 3 \mathrm{vvm}$ \\
\hline
\end{tabular}

Os ensaios foram realizados preenchendo-se os biorreatores com água e gel de alginato sem células quando necessário $(2,4 \mathrm{~L}$ para o biorreator cesta e 1,6 $\mathrm{L}$ para a coluna de bolhas), sob pressão atmosférica e $\mathrm{T}=30^{\circ} \mathrm{C}$. O procedimento encontra-se ilustrado na Figura B1, e consistiu nas seguintes etapas: 
a) ajustar os parâmetros nos quais se desejava calcular o valor de kla: freqüência de agitação e vazão de aeração (fluxômetros)

b) borbulhar nitrogênio no líquido, para que fosse eliminado todo o oxigênio dissolvido no líquido e ajustar o zero na leitura do eletrodo;

c) iniciar a aeração, até que fosse atingida a saturação (indicada pelo valor de $100 \%$, com o eletrodo previamente calibrado);

Os dados de leitura de oxigênio dissolvido foram lidos e armazenados pelo software Labview.

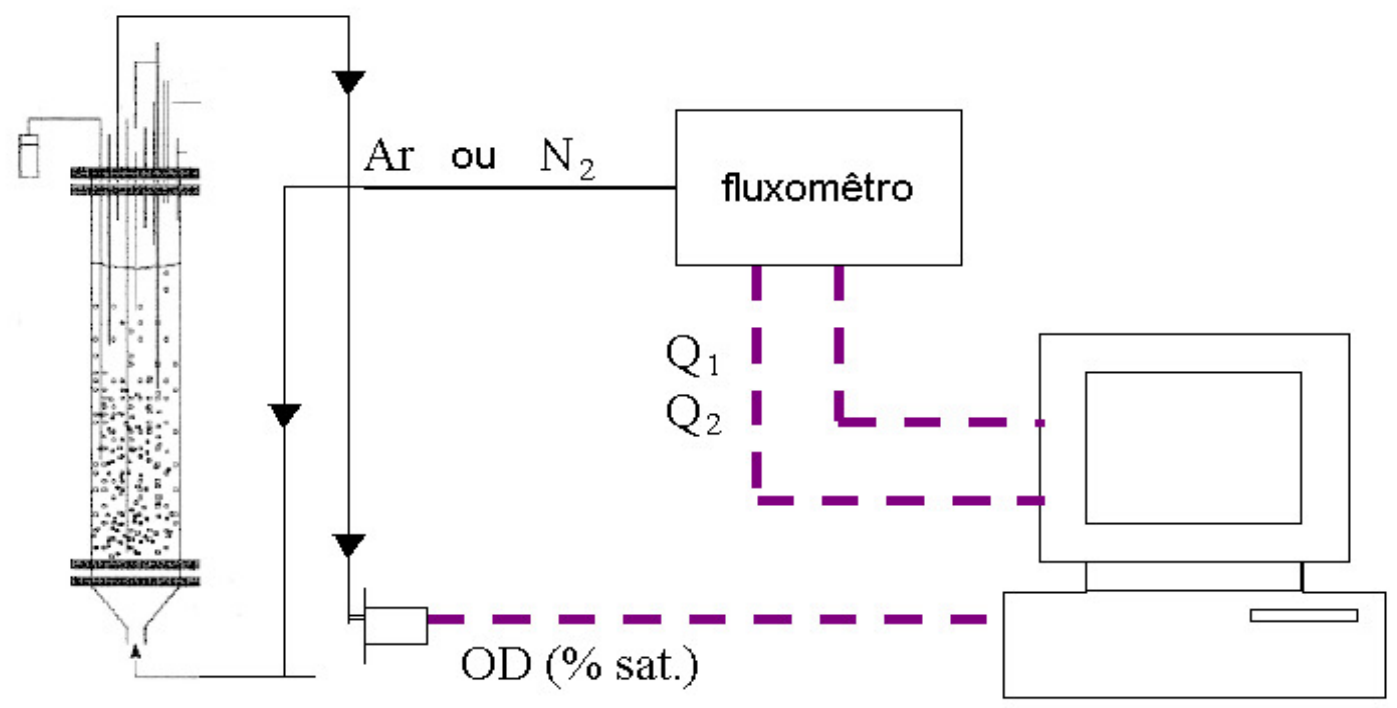

Figura B1 - Esquema do sistema para terminação do Kla pelo método dinâmico

O valor do kıa pode ser obtido, então, a partir da integração da seguinte equação:

$$
\frac{d C}{d t}=k_{L} a\left(C_{s}-C\right)
$$

onde,

$C_{s}$ é a concentração de saturação, definida na calibração (100\%);

$C$ é a concentração de oxigênio dissolvido no instante $t$ 
$k_{L} a$ é o coeficiente volumétrico de transferência de $\mathrm{O}_{2}\left(\mathrm{~h}^{-1}\right)$, que depende das condições do sistema.

Integrando a equação B.1, tem-se:

$$
\ln \left(1-\frac{C}{C_{s}}\right)=-k_{L} a \cdot t
$$

Através do coeficiente angular da reta obtida quando plota-se $\ln \left(1-\mathrm{C}_{\mathrm{C}}\right)$, obtém-se, portanto o valor de kLa.

A determinação do Kla durante cultivos pode ser feita considerando-se na equação do balanço de oxigênio o termo correspondente à respiração microbiana (SCHMIDELL, 2001).

$$
\frac{d C}{d t}=k_{L} a\left(C_{s}-C\right)-Q_{o 2} X
$$

A aplicação deste método para determinação do Kla e da respiração celular depende da minimização da transferência de oxigênio para o sistema, porém,no caso de reatores pneumáticos a dificuldade se dá porque a aeração é importante não só para transferência de oxigênio, mas também para a agitação do sistema. Como alternativa, pode-se tentar minimizar a transferência, diminuindo-se a aeração para um valor mínimo que não interfira nas medidas da concentração de oxigênio.

Considerando-se que a velocidade global de respiração será constante durante a aplicação do método dinâmico, chega-se à equação (SCHIMIDELL, 2001):

$$
\ln \left(\frac{C_{0}-C}{C_{0}-C_{01}}\right)=-\operatorname{Kla}\left(t-t_{1}\right)
$$

Assim, plotando-se $\ln \left[\left(\left(\mathrm{C}_{0^{-}} \mathrm{C}\right) /\left(\mathrm{C}_{0^{-}} \mathrm{C}_{01}\right)\right) /\left(\mathrm{t}-\mathrm{t}_{1}\right)\right]$ em função do tempo, obtém-se através do coeficiente da reta o valor de $\mathrm{k}_{\mathrm{L} a}$ 


\section{B.1.2. Determinação da respiração através do método de balanço gasoso}

O método do balanço gasoso permite o cálculo de $\left(\mathrm{Q}_{\mathrm{O} 2} \mathrm{X}\right)$ a partir de medidas das frações molares de $\mathrm{O}_{2}$ e $\mathrm{CO}_{2}$ no gás efluente do reator, como mostra a equação B.5 (SCHMIDELL, 2001):

$$
\mathrm{Q}_{\mathrm{O} 2} \mathrm{X}=\mathrm{Y}_{\mathrm{O} 2}^{\mathrm{e}} * \phi_{\mathrm{e}}-\mathrm{Y}_{\mathrm{O} 2}^{\mathrm{s}} * \phi_{\mathrm{s}} *(1 / \mathrm{V})
$$

Onde:

$\mathrm{Y}_{\mathrm{O} 2}^{\mathrm{e}}=$ fração molar ou volumétrica de $\mathrm{O}_{2}$ no ar de entrada.

$\phi e=$ vazão de ar à entrada do reator (mol ar/h).

$\mathrm{Y}_{\mathrm{O} 2}^{\mathrm{s}}=$ fração molar ou volumétrica de $\mathrm{O}_{2}$ na vazão de gás à saída.

$\phi s$ = vazão de gás à saída do reator (mol gás/h).

$\mathrm{V}=$ volume de líquido no reator.

$\mathrm{Q}_{\mathrm{O} 2}=$ Velocidade específica de consumo de oxigênio $\left(\mathrm{mmol} \mathrm{O}_{2} / \mathrm{g}_{\text {cel }} \cdot \mathrm{h}\right)$.

$\mathrm{X}=$ Concentração celular $(\mathrm{g} / \mathrm{L})$.

\section{B.1.2.1. Frações molares de oxigênio à entrada $\left(\mathrm{Y}_{\mathrm{O} 2}^{\mathrm{e}}\right)$ e saída $\left(\mathrm{Y}_{\mathrm{O} 2}^{\mathrm{s}}\right)$ do reator}

A fração molar de oxigênio no gás efluente do reator $\left(Y_{\mathrm{O} 2}^{\mathrm{s}}\right)$, bem como a fração molar de dióxido de carbono $\left(Y^{\mathrm{S}}{ }_{\mathrm{CO} 2}\right)$, foram monitoradas pelo analisador de gases da New Brunswick Scientific Co, dotado de analisadores de oxigênio Beckman Industrial mod. 755 e de dióxido de carbono Fuji Electric modelo IR-730, a cada hora durante todo o ensaio. A fração molar de oxigênio no ar de entrada $\left(\mathrm{Y}_{\mathrm{O} 2}^{\mathrm{e}}\right)$ foi adotada como 0,2095.

\section{B.1.2.2. Vazões molares de entrada de ar $\left(\phi_{\mathrm{e}}\right)$ e saída de gás $\left(\phi_{\mathrm{s}}\right)$}

A vazão molar de entrada de ar do reator $\left(\phi_{e}\right)$ foi medida e controlada por um fluxômetro de massa com controlador da Brooks Instruments mod. 5850E . Por outro 
lado, a vazão do gás à saída $\left(\phi_{s}\right)$ foi calculada através de um balanço de nitrogênio na fase gasosa, uma vez que esse gás é inerte, obtendo-se:

$$
\mathrm{Y}_{\mathrm{N} 2}^{\mathrm{e}} * \phi_{\mathrm{e}}=0,79 * \phi_{\mathrm{e}}=\mathrm{Y}_{\mathrm{N} 2}^{\mathrm{s}} * \phi_{\mathrm{S}}
$$

onde:

$\mathrm{Y}_{\mathrm{N} 2}^{\mathrm{e}}=$ fração molar de $\mathrm{N}_{2}$ na vazão de ar à entrada $=0,79$

$\mathrm{Y}_{\mathrm{N} 2}^{\mathrm{s}}=$ fração molar de $\mathrm{N}_{2}$ na vazão de gás à saída

ou , ainda:

$$
0,79 * \phi_{\mathrm{e}}=\phi_{\mathrm{s}}\left(1-\mathrm{Y}_{\mathrm{O} 2}^{\mathrm{s}}-\mathrm{Y}_{\mathrm{CO} 2}^{\mathrm{s}}\right)
$$

e, finalmente:

$$
\phi_{\mathrm{s}}=\frac{0,79 * \phi_{\mathrm{e}}}{\left(1-\mathrm{Y}_{\mathrm{O} 2}^{\mathrm{s}}-\mathrm{Y}_{\mathrm{CO} 2}^{\mathrm{s}}\right)}
$$

- Volume (V)

O volume de fermentação (V) a cada instante do cultivo, foi calculado pela equação 3.18 , a seguir:

$$
V=\text { Vo }-V_{A}-V_{D}-\text { Varr }
$$

onde:

$\mathrm{V}_{0}=$ volume inicial (após a inoculação) (L).

$\mathrm{V}_{\mathrm{A}}=$ volume acumulado de retirada de amostras $(\mathrm{L})$.

$V_{D}=$ volume acumulado de amostras desprezadas $(L)$.

$\mathrm{V}_{\text {arr }}=$ volume perdido por arraste $(\mathrm{L})$.

Os volumes $V_{0}, V_{A}$ e $V_{D}$ foram medidos, e o volume perdido por arraste $\left(V_{\text {arr }}\right)$ foi calculado através das medidas anteriores e do valor do volume final do caldo, medido no encerramento do cultivo. 
B.1.3. Determinação do Kla em biorreatores cesta e coluna de bolhas sem cultivo

As Figuras B.2 e B.3 apresentam os resultados obtidos na determinação de Kla para o biorreator coluna de bolhas sob aeração de $1 \mathrm{vvm}$, sendo a coluna preenchida apenas com água, conforme descrito no item B.1.1.

As medidas da variação da concentração de oxigênio dissolvido foram efetuadas em triplicatas e as curvas obtidas apresentaram pequenos desvios.

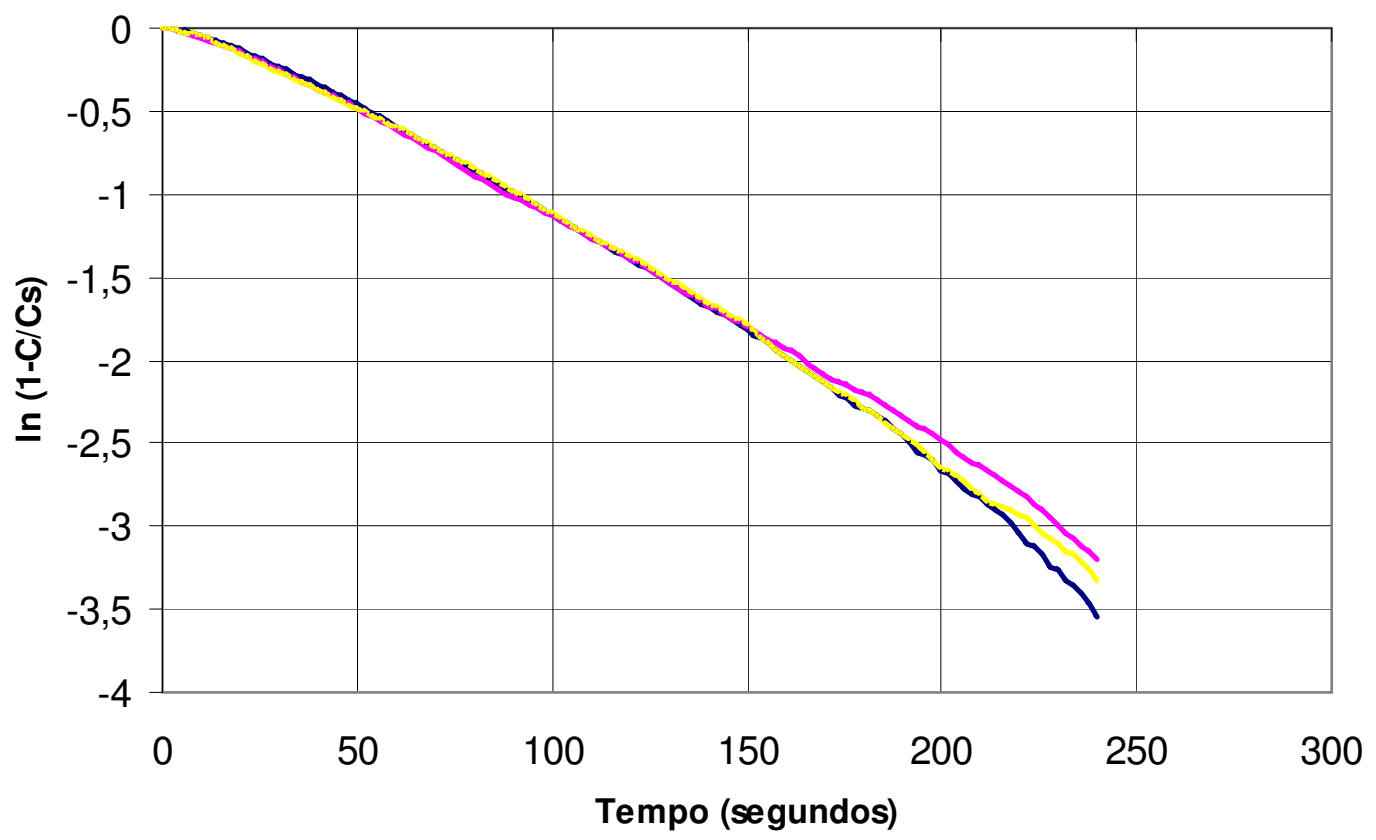

Figura B.2 - Curvas de $\ln (1-\mathrm{C} / \mathrm{Cs})$ em função do tempo no reator coluna de bolhas ( $1 \mathrm{vvm})$ 


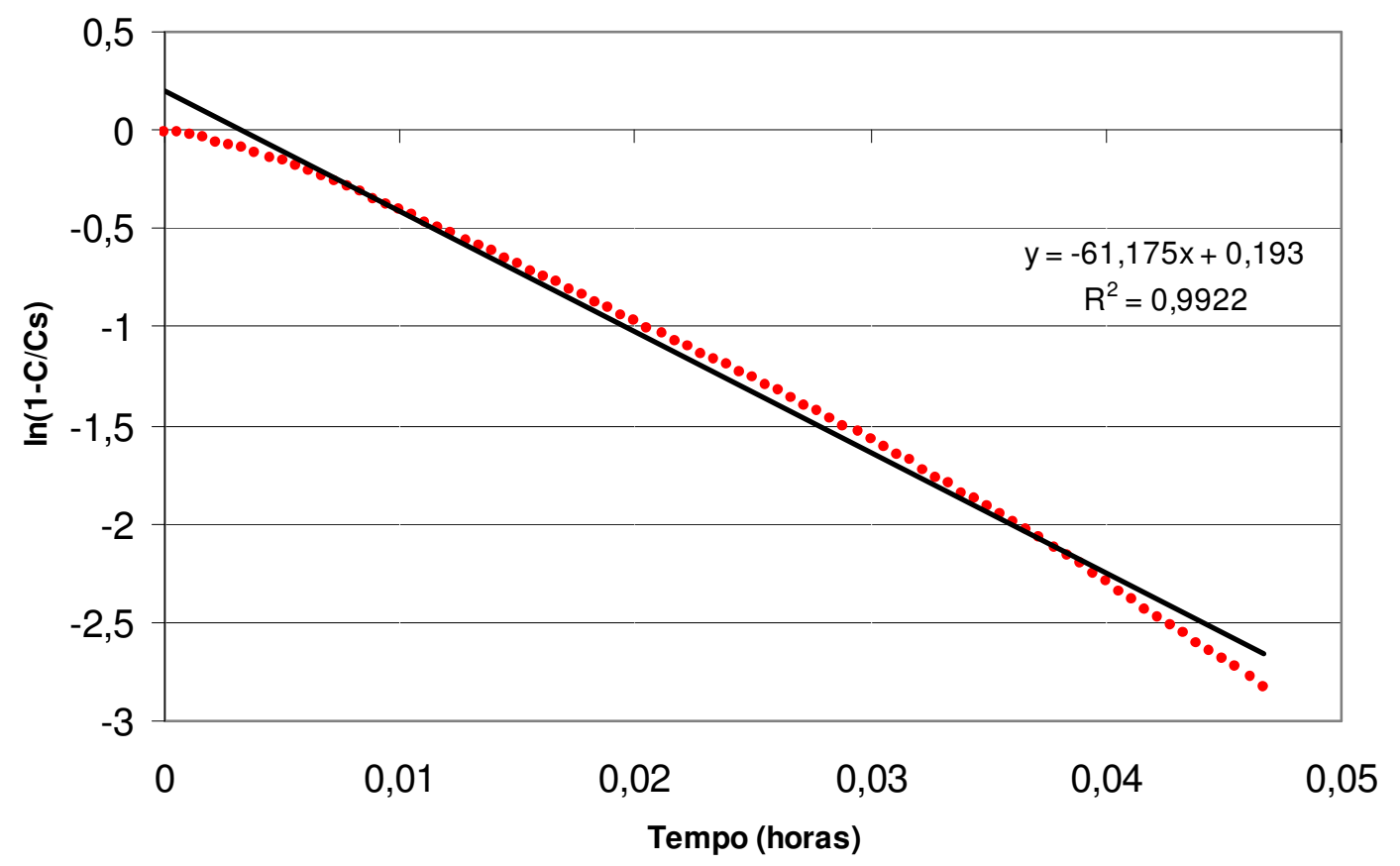

Figura B.3: Curva média de $\ln (1-\mathrm{C} / \mathrm{Cs})$ em função do tempo no biorreator coluna de bolhas (1 vvm)

Em seguida foi calculada uma curva média, e a partir desta foi determinado o coeficiente angular da regressão de $\ln (1-\mathrm{C} / \mathrm{Cs})$ em função do tempo, o qual corresponde ao valor do coeficiente de transferência de oxigênio para o sistema, obtendo-se para a condição de 1 vvm, a equação $Y=-61,175 t+0,193$, e o valor de cerca de $60 \mathrm{~h}^{-1}$ para o Kla.

De acordo com as condições apresentadas na tabela B.1, e com o procedimento descrito no início deste capítulo, foram feitas as determinações de Kla, cujos resultados estão apresentados a seguir na figura B.4, a seguir. 


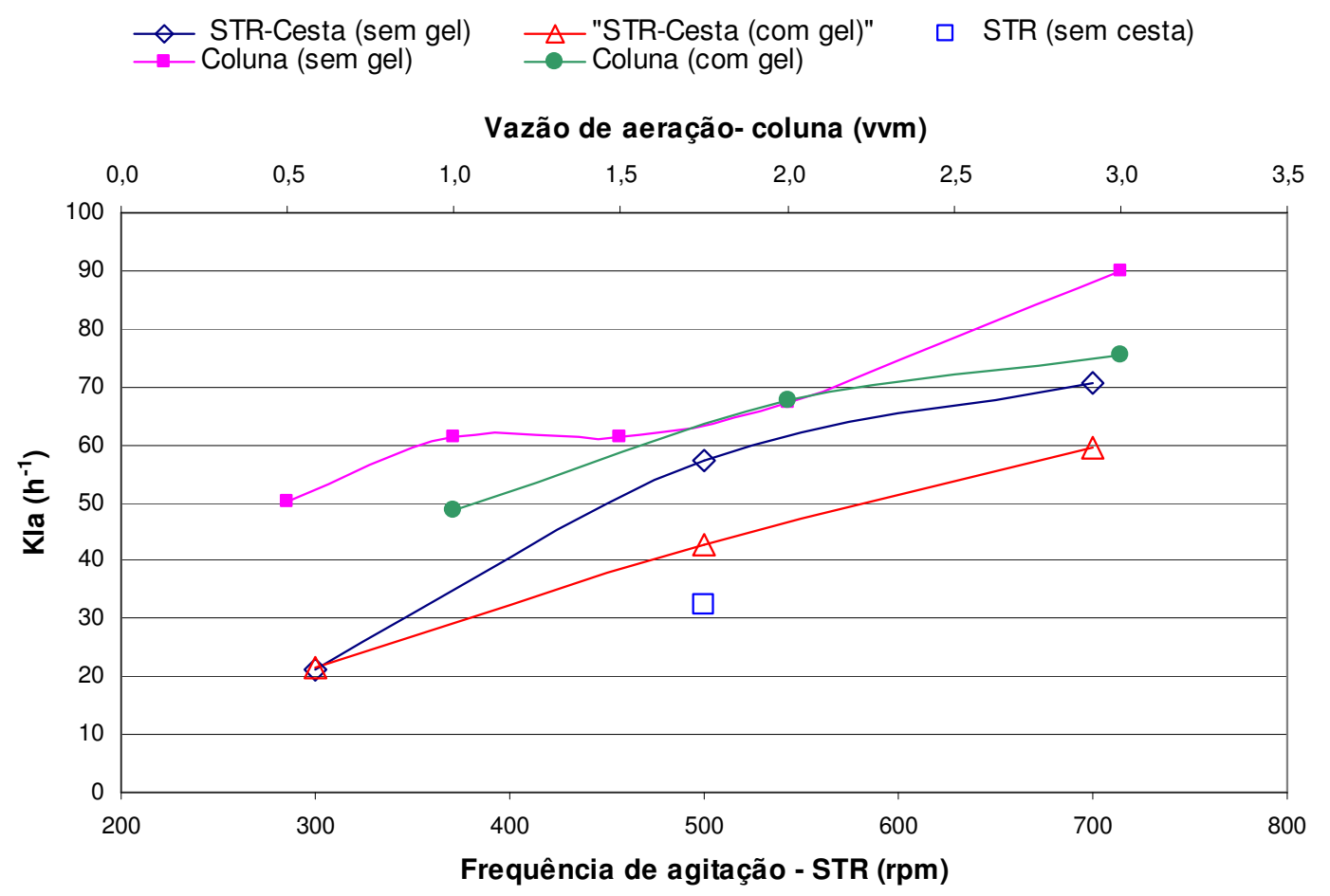

Figura B.4 - Kla $\left(\mathrm{h}^{-1}\right)$ em função da freqüência de agitação (rpm) no reator STR (1 vvm de aeração) e em função da vazão de aeração (vvm) no biorreator coluna de bolhas.

A partir da figura B.4 pode-se observar que o maior valor do coeficiente de transferência de oxigênio foi obtido no biorreator na coluna de bolhas com a vazão de aeração de 3 vvm, para o qual obteve-se um valor de Kla de $90 \mathrm{~h}^{-1}$. Para os ensaios em reator STR, o maior valor de Kla foi observado na condição de 700 rpm com a cesta e sem a presença de gel, valor este da ordem de $70 \mathrm{~h}^{-1}$, similar ao obtido para o biorreator coluna de bolhas com vazão de 2 vvm. Os valores de Kla apresentados por Lavarda (2003), para o reator tipo torre, em meio de cultivo sem gel e sem microrganismo ( cerca de $120 \mathrm{~h}^{-1}$ - aeração de $3 \mathrm{vvm}$ ), foram superiores aos obtidos com o biorreator coluna de bolhas, o que se justifica pelo diferente tipo de aspersor utilizado em seu trabalho (em forma de cruzeta, com orifícios laterais de $300 \mu \mathrm{m}$ ), o qual deve ter favorecido a transferência de oxigênio para o líquido, provavelmente pela geração de uma quantidade maior de bolhas e de menor diâmetro no sistema. Diferentemente dos resultados apresentados por Lavarda (2003), a presença de gel de alginato de cálcio, não provocou nenhum 
efeito no sentido de favorecer um aumento nos valores do coeficiente de transferência de oxigênio na coluna de bolhas.

Em conformidade com a literatura (PRADELLA, 2001), a coluna de bolhas, assim como reatores tipo airlift, são indicados para cultivos que necessitam de valores de Kla elevados, como é o caso de cultivos de Streptomyces olindensis, porém, outros parâmetros que afetam a transferência devem ser levados em consideração na escolha do melhor reator, como por exemplo interferência da viscosidade do meio de cultivo na presença de altas concentrações celulares, a interferência de efeitos difusionais, a utilização de sistema com células imobilizadas, entre outros.

\section{B.1.4. Determinação do Kla e respiração nos ensaios em biorreatores cesta e coluna de bolhas durante cultivo}

\section{B.1.4.1. Velocidade de respiração para o ensaio $\mathrm{SI}-300-80$}

Como mencionado anteriormente (item 3.4.4.2 - Materiais e Métodos), no ensaio SI-300-80 foram efetuadas medidas das frações de gases na saída do reator. Com estes dados foi possível calcular pelo método do balanço gasoso, os perfis de velocidades global $\left(\mathrm{Q}_{\mathrm{O} 2 \mathrm{X}}\right)$ e específica $\left(\mathrm{Q}_{\mathrm{O} 2}\right)$ de respiração ao longo do cultivo, os quais encontram-se na figura B.5. Apenas os dados de $\mathrm{CO}_{2}$ foram considerados para o cálculo da velocidade de respiração e admitiu-se um valor de $R Q=1$, com base trabalhos anteriores (MARTINS, 2001; PAMBOUKIAN, 2003), tendo em vista que o processo da produção da retamicina é estritamente aeróbio.

A Figura B.5, a seguir, apresenta dos dados de respiração obtidos no ensaio SI-300-80 e a Tabela B.2 apresenta uma comparação dos valores obtidos por Martins (2001) com células livres de Streptomyces olindensis ICB20. 


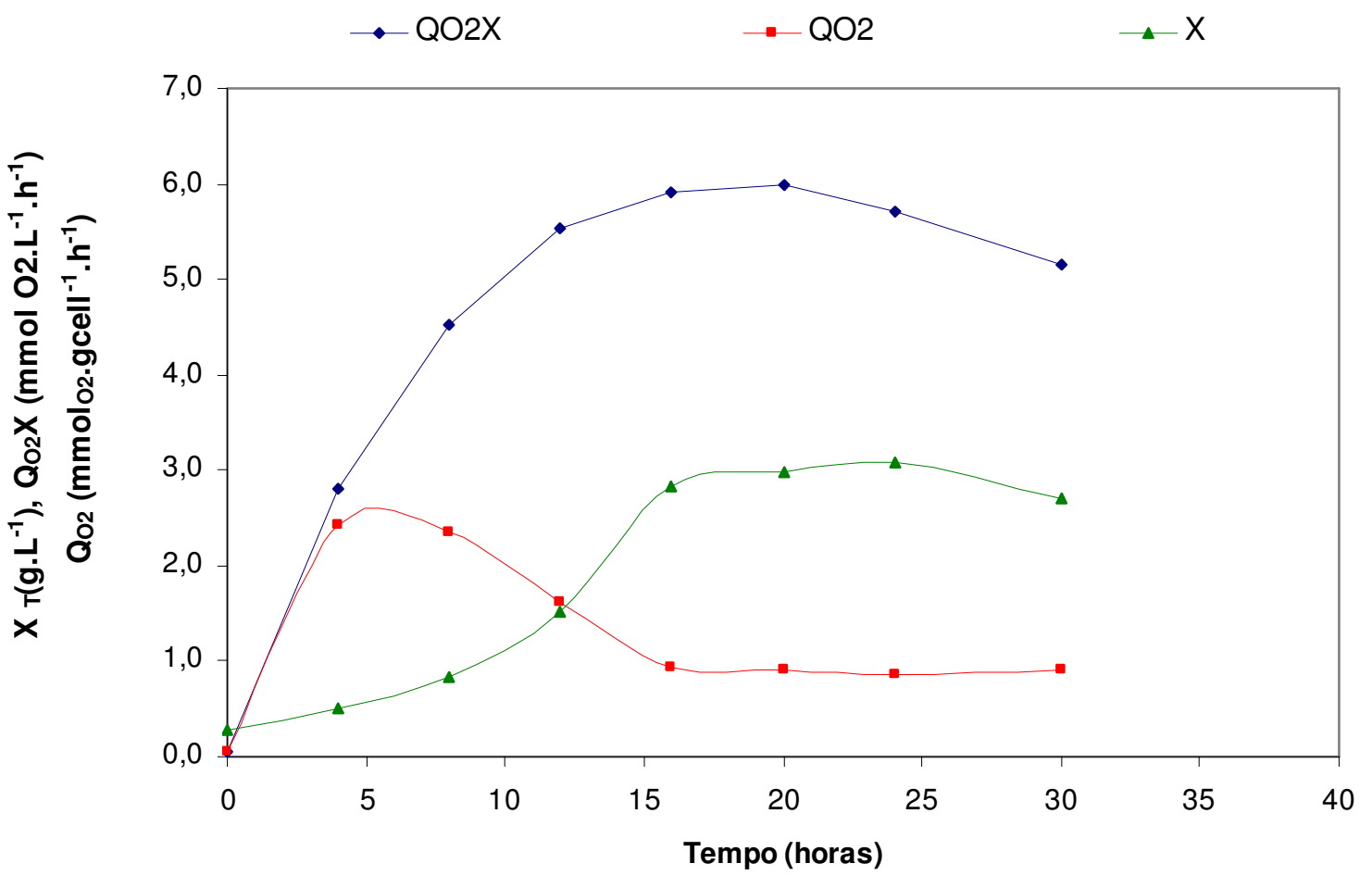

Figura B.5 - Perfis de concentração celular (X), velocidades global (Qo2X) e específica (Q०2) de respiração no ensaio SI-300-80.

Tabela B.2 - Resumo dos resultados obtidos nos ensaios SI-300 (células imobilizadas) e no ensaio 5-1 R1 (células livres - MARTINS, 2001)

\begin{tabular}{|l|l|l|}
\hline Grandezas & Sl-300-80 & $5-1 \mathrm{R} 1$ \\
\hline $\mathrm{t}_{\mathrm{O} 2}(\mathrm{~h})$ & 16 & 10 \\
\hline $\mathrm{QO}_{2} \mathrm{X} \max \left(\mathrm{mmol} \mathrm{O}_{2} / \mathrm{L} . \mathrm{h}\right)$ & 6 & 16,09 \\
\hline $\mathrm{t}_{\mathrm{O} 2}(\mathrm{~h})$ & 5 & 9 \\
\hline $\mathrm{QO}_{2} \max \left(\mathrm{mmol} \mathrm{O}_{2} / \mathrm{g}_{\mathrm{cel}} \cdot \mathrm{h}\right)$ & 2,5 & 6,65 \\
\hline$\mu \operatorname{máx}\left(\mathrm{h}^{-1}\right)$ & 0,11 & 0,27 \\
\hline
\end{tabular}

onde:

$\mathrm{t}_{\mathrm{O} 2}=$ instante de máxima velocidade global de consumo de oxigênio $\left(\mathrm{Q}_{\mathrm{O} 2} \mathrm{X}\right)(\mathrm{h})$ t'o2 = instante de máxima velocidade específica de respiração (Q $\left.\mathrm{Q}_{\mathrm{O}}\right)(\mathrm{h})$.

Comparando-se os valores da respiração obtidos no ensaio SI-300-80 em relação aos resultados apresentados por Martins (2001), contatou-se que os valores são consideravelmente inferiores, em concordância com a cinética mais lenta e as limitações difusionais observadas para $S$. olindensis imobilizadas em gel de alginato, conforme já discutido no item 4 - Resultados e discussão. 
Não foi possível a determinação de medidas de Kla e respiração pelo método dinâmico, nos cultivos em biorreator coluna de bolhas, devido às baixas concentrações de oxigênio dissolvido a partir de 10 horas de cultivo nos ensaios com células livres. Também não foi possível a aplicação deste método nos ensaios com células imobilizadas ao longo de cultivo na coluna de bolhas porque não observouse reprodutibilidade nas repetições das medidas para um mesmo instante de cultivo. Por isso serão apresentados apenas os dados de Kla obtidos no instante de 6 horas de cultivo para os ensaios LC2 e IC2.

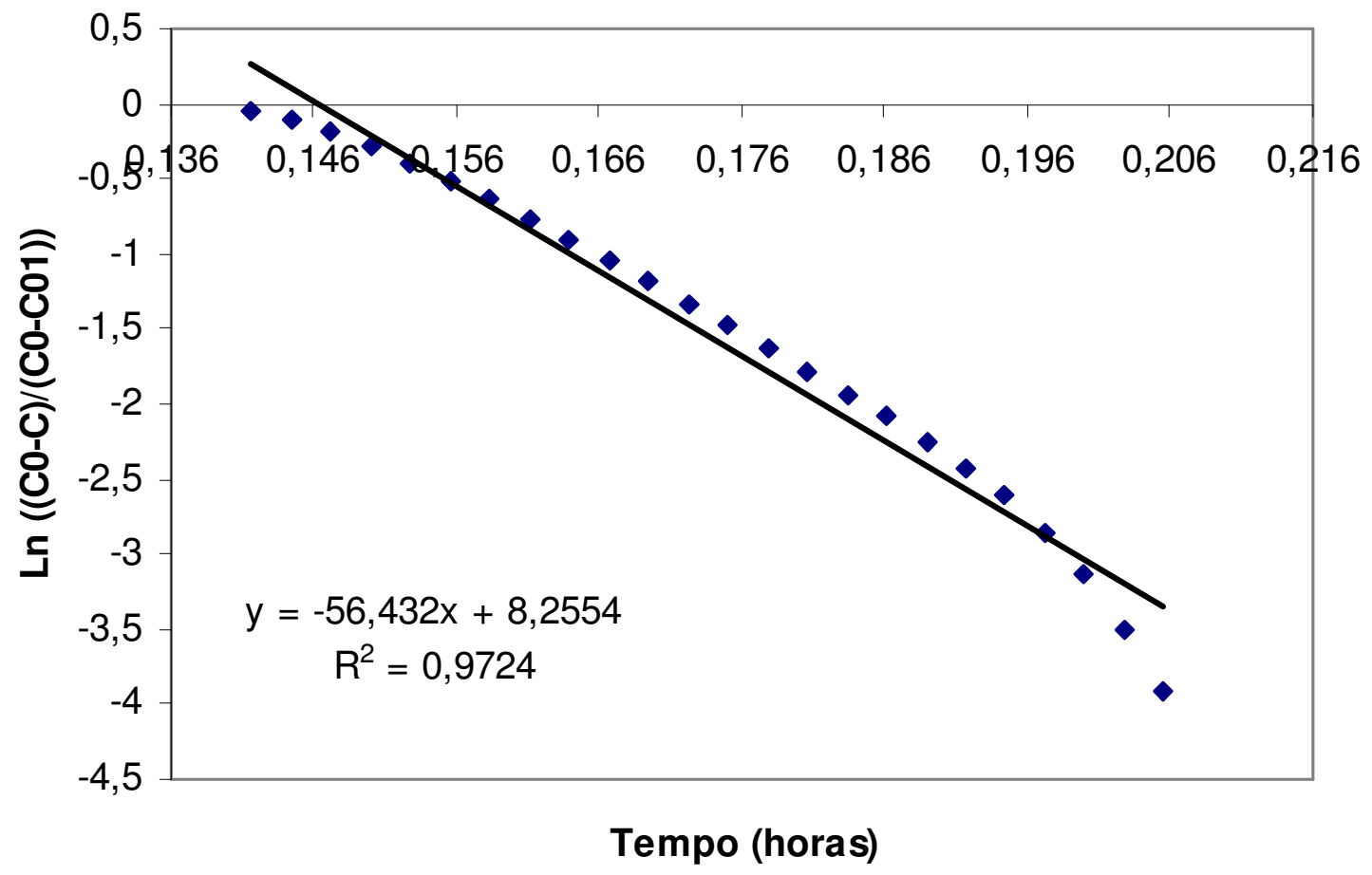

Figura B.6 - Determinação do kla com 6 horas de cultivo no ensaio LC2 


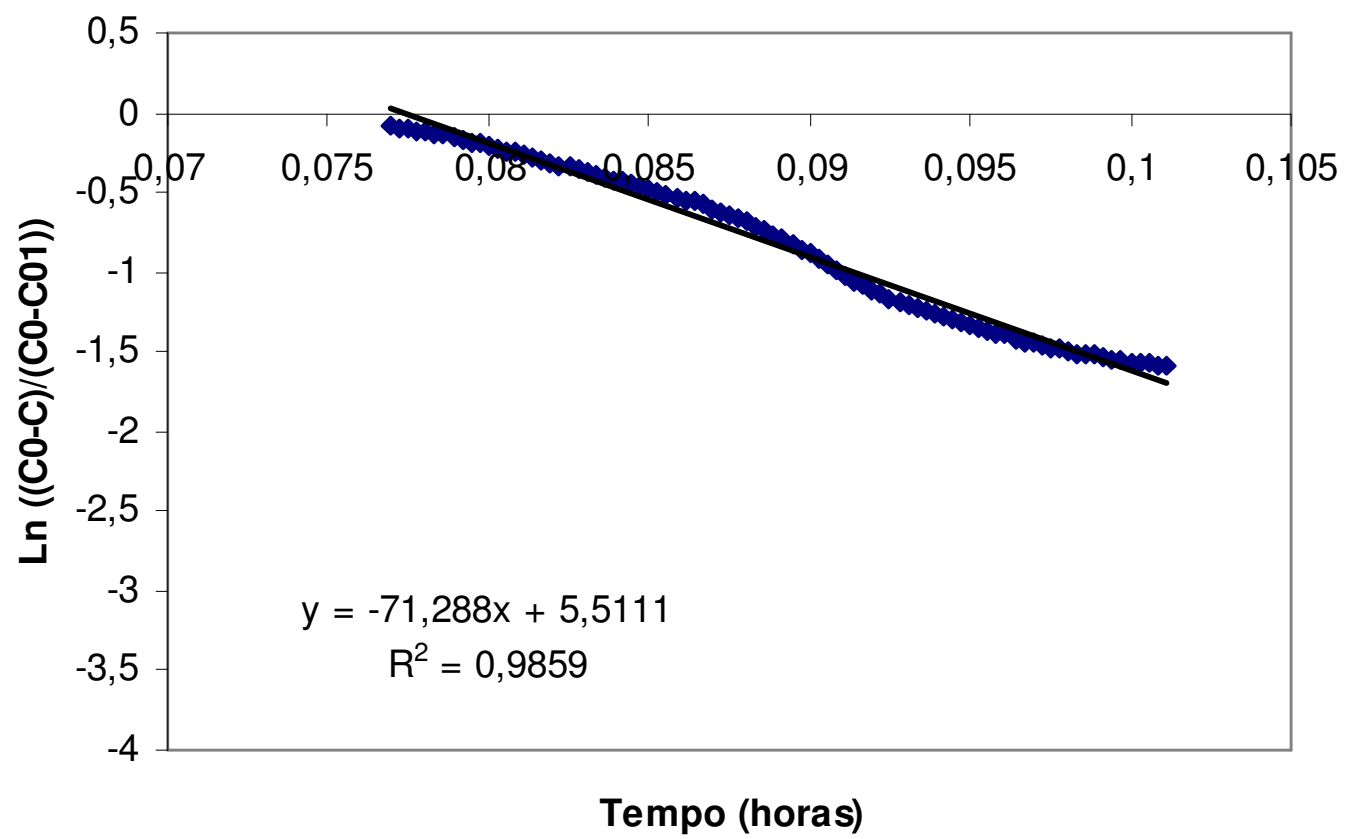

Figura B.7 - Determinação do kla com 6 horas de cultivo no ensaio IC2

De acordo com a equação B.3, plotou-se os dados de concentração de oxigênio durante a aplicação do método dinâmico nos ensaio LC2 e IC2 (Figuras B.6 e B.7), obtendo-se as retas de regressão $Y=-56,432 t+8,255$ e $Y=-71,288 t+$ 5,511 , respectivamente.

O valor do Kla obtido para o ensaio LC2 foi de $56,4 \mathrm{~h}^{-1}$, valor este inferior ao obtido no ensaio na coluna de bolhas apenas com água e aeração de 2 vvm (em torno de $68 \mathrm{~h}^{-1}$ ), enquanto que o valor do Kla obtido para o ensaio IC2 foi em torno de $71 \mathrm{~h}^{-1}$, valor este mais próximo ao obtido no ensaio com água e gel (em torno de $\left.68 \mathrm{~h}^{-1}\right)$. 